\title{
We Lose That We May Find: \\ Fantasy and Defamiliarisation in \\ J. R. R. Tolkien and C. S. Lewis
}

\author{
by \\ Amy Stimson \\ A thesis \\ submitted to Victoria University of Wellington \\ in fulfilment of the requirements for the \\ degree of Doctor of Philosophy \\ VICTORIA UNIVERSITY OF \\ WELLINGTON \\ TE HERENGA WAKA
}

Victoria University of Wellington 


\section{Contents}

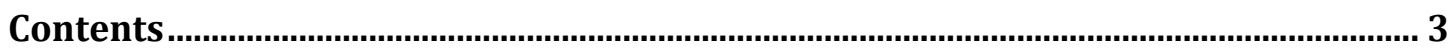

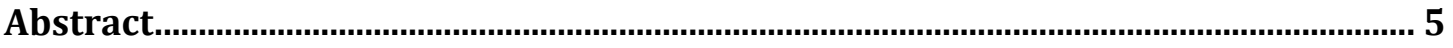

Biographical Introduction: The 'Leaf Mould' of the Mind............................................. 7

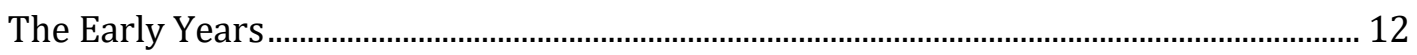

Oxford Years: Inklings and Public Reception .......................................................................... 14

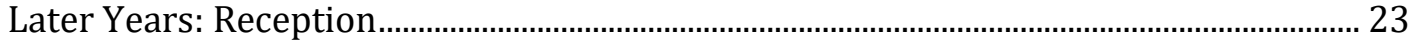

Modern Literary Criticism................................................................................................... 26

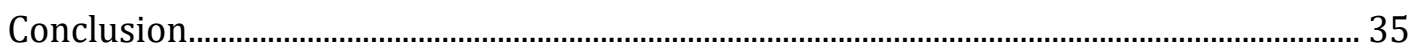

Methodological Introduction: Losing That We May Find.............................................37

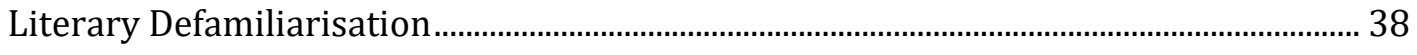

History and Uses of Defamiliarisation ........................................................................... 40

Theological and Fantastic Defamiliarisation ............................................................................ 45

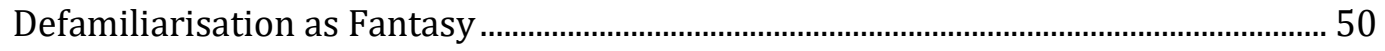

Poetic and Conceptual Defamiliarisation ......................................................................... 52

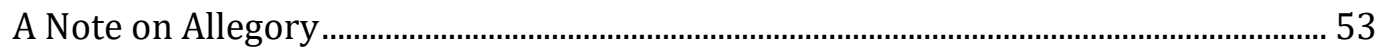

We Lose that We May Find................................................................................................. 58

Chapter One: The Beginnings of Defamiliarisation .......................................................61

Beginning with Defamiliarisation: Entering Faerie............................................................... 62

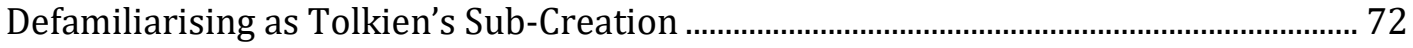

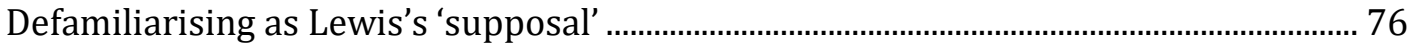

Defamiliarising Creators: The Storyteller........................................................................... 79

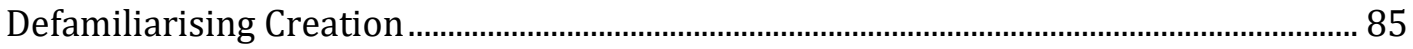

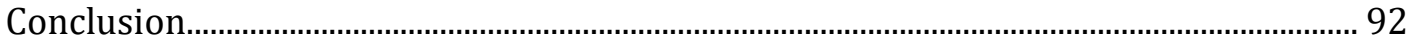

Chapter Two: Riddles and Reading Between the Lines .................................................. 93

Riddles, Riddling Through, and Reading Between the Lines.............................................. 94

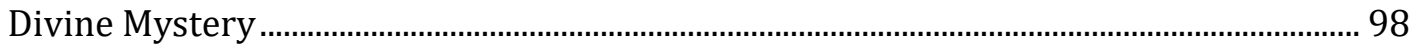

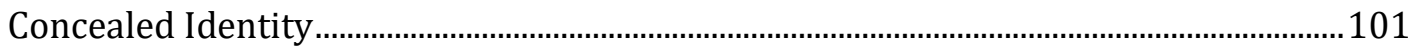




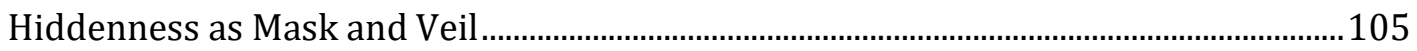

Masks as Transformation ...............................................................................................112

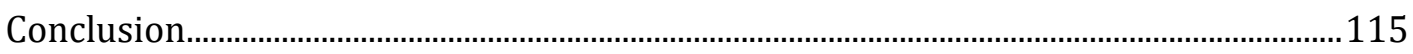

Chapter Three: Christ (Anti)Types …..................................................................... 117

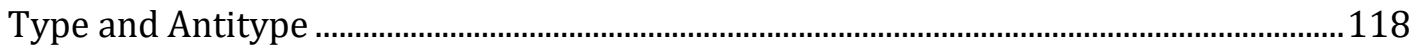

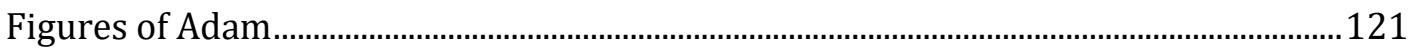

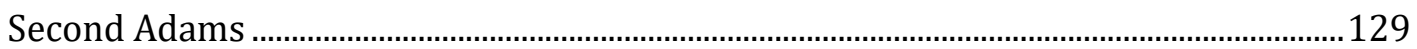

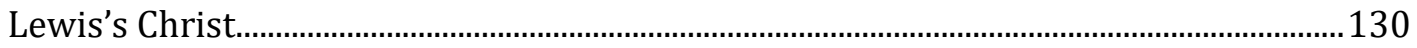

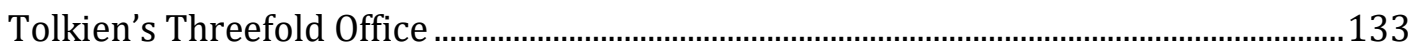

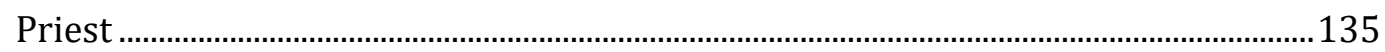

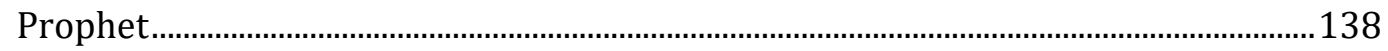

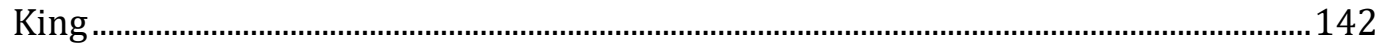

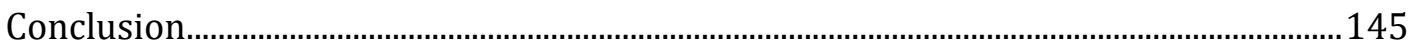

Chapter Four: Death and Endings (and Beginnings) …........................................... 147

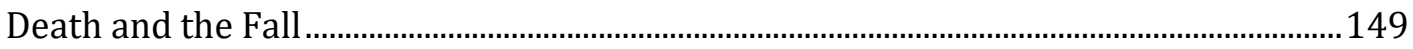

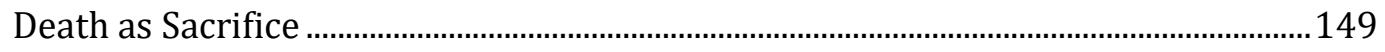

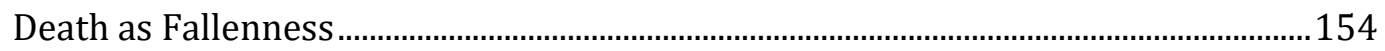

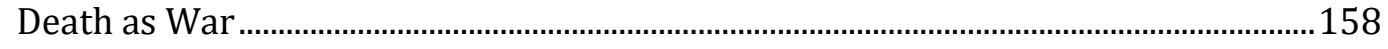

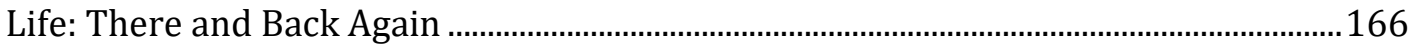

The Paradox of the Grain of Wheat Principle: Dying to Live..........................................166

The Paradox of Home …………………................................................................................

The Paradox of Being Born Again: Death without Dying ................................................174

The Paradox of Death: O Death, Where is Thy Sting? .....................................................177

Conclusion: If Death is Irrelevant, Endings are Irrelevant Too .......................................180

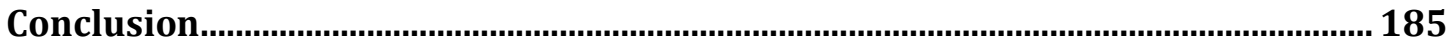

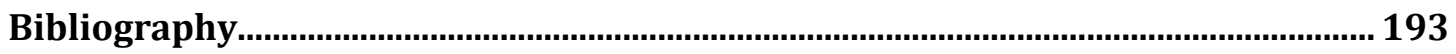

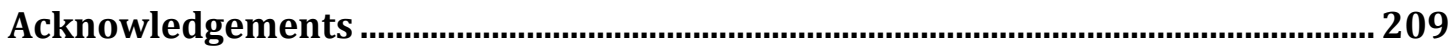




\section{Abstract}

It has been said that art is repetition with variation. My research examines the technique of defamiliarisation - that is, making the familiar strange in order to re-invigorate wonder in the familiar - in the fantasy fiction of C. S. Lewis and J. R. R. Tolkien by exploring the fairy tale and the fantastic mode as useful vehicles or structures for the embodiment of theological themes within story. As Tolkien and Lewis were writing within a largely "de-mythologising" cultural moment, they attempted to write fiction that would re-mythologise not only the genre of fantasy, but central elements of belief. Their fictions are an experimental, collaborative, and creative space, and yet are still a product of the complex relationship between the theological and the fantastic in the stories of invented worlds. I aim to provide a reading of the possibilities of fantasy both as an invitation to experience and explore the unknown territory of invented worlds, as well as a sophisticated and engaging product of theological discourse.

Given that there has been prominent criticism that denounces theological fantasy (and particularly Lewis's Narnian chronicles) as a site of a didactic project engaged in the socialisation of the child, there seems to be an opportunity to propose alternative readings that emphasise the possibility of a theologically-inspired fantasy that attempts to be engaging and provocative. That is, defamiliarised texts can be read as a space for the exploration of ethics, emotional engagement, and imaginative potential. It would seem a lens is required that keeps both in focus at the same time: that which is familiar (contexts, stories, and genres) and that which is imaginative invention. The familiar must first be lost, that it may be rediscovered in the strange.

Looking in turn at motifs of (sub-)creation and the Fall, the mystery of the divine (riddles and paradox), soteriology (typological Adam and Christ figures), and ultimate redemption and restoration (death and endings), as well as the conception of the role of the artist, I argue that defamiliarisation is an appropriate paradigm through which to discover the restorative vision of Christian fantasy, seeing it as a story mode that embodies theological tradition even as it restores and invigorates that same tradition. Through examining how these authors have defamiliarised Biblical characters, plots, and motifs, we can envision the possibilities of critical thinking, human empathy, and creative participation in story. We can understand techniques used to prompt readers to explore and evaluate for themselves, to think outside of the box, to make meaning in the narrative gaps, and we can examine how the authors explore belief. 


\section{Biographical Introduction: The 'Leaf Mould' of the Mind}

C. S. Lewis once said to J. R. R. Tolkien (as the latter subsequently recalled): "Tollers, there is too little of what we really like in stories. I am afraid we shall have to write some ourselves" (Tolkien, Letters of J. R. R. Tolkien 378). This remark, casual though it might appear, captures the attitude behind his and Tolkien's entire creative output (and, to some extent, their academic work as well). They had elevated ideas of what story ought to be, and determined that they would supply the demand, if no one else could be found to do so. Despite being in many ways a throwaway remark, it was the beginning of a story-writing wager that eventually resulted in Tolkien's posthumously published The Lost Road, and Lewis's Space Trilogy: it certainly sheds light on how seriously both authors took their interest in story. Thought to take place circa 1937, this conversation happened the same year that Tolkien's first novel The Hobbit was published, and the year Lewis was writing his first major fictional work, Out of the Silent Planet, to be published the following year. Tolkien and Lewis shared a common perspective on story, which emerges quite entertainingly from a favourite anecdote of mine involving their shared distaste for the Disney feature film Snow White and the Seven Dwarves, co-incidentally also released in 1937. Fascinating as it may be to imagine these two Oxford dons not only turning their intellects to virulent critique of the film (and moreover sitting through a Disney film together), their aversion to the Disney treatment of folk and fairy tale speaks volumes of their deep engagement with the genre as one capable of great profundity. In a letter to a friend in 1939, C. S. Lewis wrote:

Leaving out the tiresome question of whether it [Snow White and the Seven Dwarves] is suitable for children (which I don't know and don't care ${ }^{1}$ ) I thought it almost inconceivably good and bad - I mean, I didn't know one human being could be so good and so bad. The worst thing of all was the vulgarity of the winking dove at the beginning, and the next worst the faces of the dwarfs. Dwarfs ought to be ugly of course, but not in that way. And the dwarfs' jazz party was pretty bad. I suppose it never occurred to the poor boob that you could give them any other kind of music. But all the terrifying bits were good, and the animals most moving: and the use of shadows (dwarfs and vultures) was real genius. What might not have come of it if this man had been educated - or even brought up in a decent society? (Collected Letters: Volume II 242)

\footnotetext{
${ }^{1}$ For a man now known as one of the twentieth century's foremost children's authors, Lewis's selfconfessed disregard of what is suitable for that age-group is surprising - although I believe this is more to do with dismissal of the category of 'suitable' as a worthwhile consideration, than a dismissal of children's story as a whole.
} 
Lewis's disdain for Walt Disney's education is almost too elitist even to be amusing. Yet it is easier, nowadays, to compare the vulgarity (as Tolkien and Lewis must have seen it) of Disney's dwarves with the nobility of Tolkien's - especially when one contrasts the Disney 'jazz party' with the evocative Gregorian music in Peter Jackson's film trilogy of The Hobbit (2012-2014).2 The tone and the sentiments in Lewis's letter demonstrate a fiercely protective response to the light handling of fantasy. Lewis later used the film to illustrate his academic views on what constituted proper use of archetype in his Preface to Paradise Lost (1942). He wrote that the film combined "good unoriginality in the drawing of the queen. She was the very archetype of all beautiful, cruel queens" (58), but also "bad originality in the bloated, drunken low comedy faces of the dwarfs" (58). He felt that even remakes of familiar folk stories should be written respectfully and with flair. ${ }^{3}$ Tolkien too was particularly outspoken in his letters about his "heartfelt loathing" (Letters 17) for the Disney studios, for the way Disney turned myth into "farce" (Scull and Hammond 8). Tolkien had devoted his Andrew Lang lecture, reproduced in the 1947 essay "On Fairy-Stories" - and much of his study and personal storytelling prowess to his interpretation of fairy tale as a noble art form. He thought that Disney's take was "hopelessly corrupted," and that the effect of it in general (some "admirable or charming passages" notwithstanding) was "disgusting" and "ridiculous" (quoted in Scull and Hammond 210). Such opinions are of a piece with Tolkien's resistance to cartoon adaptations of his work, an attitude Lewis shared. In 1954, Lewis turned down a film pitch for The Lion, the Witch and the Wardrobe, commenting "I am sure you understand that Aslan is a divine figure, and anything remotely approaching the comic (above all anything in the Disney line) would be to me simple blasphemy" (as quoted in Hooper, C. S. Lewis: A Complete Guide to His Life and Works 438). The drawback of the Disney way was that it sacrificed all nuance or gravitas for the sake of appealing to the masses (or even only to small children) with unsubtle, cookie-cutter simplicity, or trivialising comedy - and at the expense of a thoughtful telling of the tale. What Tolkien and Lewis objected to was that belittling of story to the point of rendering it infantile. Nobody was writing the kinds of stories they admired, or so they believed, and so they took on the task with greater reverence for the profundity of fantasy.

\footnotetext{
2 Tolkien's dwarves do have some almost parodic quirks it is true; however, Tolkien could never be accused of puerile characterisations. He shows deep respect for their (albeit fictional) people, heritage, and culture.

${ }^{3}$ His critique of the Disney feature served to illustrate his argument that mythical poetry could be original but respectful of "its ingredients" (57). Certain archetypes - such as "giants, dragons, paradises, gods, and the like" (57) - are themselves "expression of certain basic elements in man's spiritual experience" and therefore to give them "radically new characters is not so much original as ungrammatical" (57). Lewis venerated judicious employment of both good unoriginality (as with the embodiment of the evil queen) and good originality (as with the 'genius' employment of shadows and vultures) within archetype admittedly nuanced distinctions which I shall return to in my third chapter.
} 
Tolkien and Lewis embrace a wide range of genres - mythology, children's fantasy, Christian doctrine, and academic essay among others - and although their fictions are different, their religious, and fantastic, foundations are the same. If, as Tolkien says, the output of the artist comes from the "leaf-mould' of the mind" (as quoted by Carpenter, J. R. R. Tolkien 126), then this leaf-mould was influenced in both writers by their shared views of fantasy and Christianity. As A. N. Wilson puts it, Lewis (and perhaps one may say Tolkien as well) "is one of those very rare writers whose Muse appears to be an anima naturaliter Christiana" (C. S. Lewis: A Biography loc. 2850). Taking their lives as a vantage point from which to view their context and concerns, I will draw out their creative outlook on the separation of fantasy and religion, whereby (in the former) Christianity should be present, but not overt. By considering the context into which Tolkien and Lewis were writing, their personal and literary lives, as well as a brief literature review from the time of the publication of their greatest works until the present day, I lay the groundwork for a discussion on the intersection of theology and fantasy, and the technique of defamiliarisation which allows them all to interact.

At this juncture, it is interesting to note how perfectly their respect for fantasy corresponded with the zeitgeist of the mid-twentieth century, which saw a renewed interest in fable and mythology. It is likely that Tolkien and Lewis were influenced (however subtly) by the work of philosophers such as Carl Jung, for whom the 'collective unconscious' was populated by 'archetypes' common to a range of mythologies. ${ }^{4}$ Popular fascination with mythology at the time owed a great deal to rising interest in Jung's work, and this interest coincided with Tolkien and Lewis using their writing to revive interest and belief in fable and religion. Instrumental both to Lewis's conversion to theism in the 1930s and to the artistic treatises that he and Tolkien later wrote was the idea that Christianity itself was 'True Myth'.5 The idea that all stories were one, originating from God, gave Tolkien and Lewis an ontological foundation for their creations. This means that at the time Tolkien and Lewis would have been conceptualising their most popular fantasy worlds, their own world was experiencing a renewed interest, even belief, in the power of the fable to explore deeper meaning and psychological truth. Although neither Tolkien nor Lewis particularly trusted that fascination with psychoanalysis, their orientation towards mythology (and mythology that was analogical) was something that they had in common with Jung. For them, what remained the foundation of their fantasy, despite creating very different

\footnotetext{
${ }^{4}$ Certain rudimentary correlations have already been made between Jung, Tolkien, and Lewis in articles such as Micah Sample's “Lewisian 'True Myth' and the Jungian Theory of Archetypes” (2019).

${ }^{5}$ Lewis wrote this summary to his friend Arthur Greeves: "Now the story of Christ is simply a true myth: a myth working on us in the same way as the others, but with this tremendous difference that it really happened: and one must be content to accept it in the same way, remembering that it is God's myth where others are men's myths" (Collected Letters: Volume I 976-77).
} 
fantasy worlds, was the source of this True Myth: the Christianity which was wholly distinct from, yet very much present in, all mythology. ${ }^{6}$

Tolkien and Lewis were convinced that certain subjects, genres, and stories were not being written, or were at the very least being overlooked. This conviction was what led them to try and reintroduce these subjects, genres, and stories in such a way that those who might be tempted to dismiss or overlook them would think twice. "The whole art," Lewis went on to say in his Preface to Paradise Lost, "consists not in evoking the unexpected, but in evoking with a perfection and accuracy beyond expectation the very image that has haunted us all our lives" (58). Suffice it to say that the opinions of Tolkien and Lewis were that the archetypes of religious mythology demanded greater grandeur and thoughtful creativity even within a prescribed form. Here, a scholar of the works of Tolkien and Lewis begins to see their paradoxical use both of the familiar and of the unexpected within these discussions. Whatever originality it possesses in artistic execution, their literature nevertheless resonates deeply with a vague sense of what is familiar, haunting near the edge of the imagination. This sentiment is at the heart of their fiction, and of this thesis on their use of defamiliarisation, their concern to get past the obstacle of familiarity.

How then is one to approach two such esteemed fantasists? A significant number of books exist on the lives and works of these authors - a testament to an ongoing popular interest which persists to this day. These include the encyclopaedic: The Tolkien Companion and Guide (2006) by Christina Scull and Wayne C. Hammond, and Walter Hooper's C. S. Lewis: A Complete Guide to His Life and Works (1996). There are also biographies by friends or admirers, often including accounts of an actual meeting with the author (such as Humphrey Carpenter's J. R. R. Tolkien: A Biography (1977), and Stuart D. Lee's A Companion to J. R. R. Tolkien (2014)), and personal anecdotes, as in Alister McGrath's C. S. Lewis, A Life: Eccentric Genius, Reluctant Prophet (2013), and Catherine Mcllwaine's Tolkien: Maker of Middle-earth (2018). Tolkien's son Christopher has made a significant contribution in publishing Tolkienalia and providing forewords to many pieces written on him. These stories describing 'what they were really like' certainly satisfy the admirers (for whom they were surely intended). Indeed, it is difficult to begin a thesis such as mine without sweeping general statements. A brief, comparative overview of the compendiums available on each individual would quickly reveal that a specific inclination towards the hagiographic belongs more noticeably to those dealing with C. S. Lewis.

\footnotetext{
${ }^{6}$ That is, as pointed out by Louis Markos, the belief that "other philosophies, religions and cultures have hit on certain aspects of the truth" and certain of their non-Christian stories "catch a glimpse of the true glory of the triune God" (From Achilles to Christ 12).
} 
For example, John Bremer's brief biography in Jeffrey D. Schultz and John G. West Jr.'s The C. S. Lewis Readers' Encyclopedia (1998), begins in this way:

To convey the sheer brilliance of Lewis's natural talents is not easy. He combined an intelligence of the highest order with a prodigious memory and a creative imagination, and his energy was such that everything he did had an intensity, and sometimes exclusivity, that heightened the impact of his impressive talents. (9)

Other accounts are similar, such as Christopher W. Mitchell's foreword in the same book, which reads: "C. S. Lewis remains one of the most enduring and often-quoted writers in England and America," and "one of the most influential spokesmen for Christianity in the English-speaking world" (Mitchell 7). Mitchell's writing is characteristic of the tone of these books, tending to fall back on their subject's popularity and reputation.

T. A. Shippey's landmark biography of J. R. R. Tolkien is subtitled, quite appropriately, Author of the Century (2001). There is a trend in biographies and secondary material of giving over the seriousness of both writers' mythological approach to popularist or Christian orientations. In general, the tone of Tolkien scholarship is comparatively more formal and austere - anxious perhaps not to be caught up in anything approaching 'fandom' - unlike some of the responses by admirers of Lewis. The Ballantine Books revised edition of The Hobbit (1973), for example, incorporates a brief profile of Tolkien, where his fantasy fiction gets only a brief introduction, and his time at Oxford is at the forefront: his role as Professor of Anglo-Saxon from 1925 to 1945 and then Merton Professor of English Language and Literature, as well as his interest in the literary and linguistic tradition of the English West Midlands. The tone of Stuart D. Lee, in A Companion to J. R. R. Tolkien, is firmly anti-sensationalist: he asserts that he has avoided what he called "the temptation to dive directly into his mythology" in order first to "have a more balanced view of Tolkien's fictional work," and gives first priority "to exploring Tolkien's career and impact as an academic" (2). Even so, Tolkien's influence upon twentiethcentury fantasy cannot be overstated. As modern satiric fantasist Terry Pratchett pointed out in an interview with Therese Littleton: "Tolkien appears in the fantasy universe in the same way that Mount Fuji appeared in old Japanese prints. Sometimes small, and sometimes big and closeto, and sometimes not there at all, and that's because the artist is standing on Mount Fuji" (Pratchett and Littleton). According to critic Dimitra Fimi, the impact of Tolkien's "legacy on modern fantasy continues to be strong [...] slowly moving towards the position of 'canonical' author within the genre, with whom younger generations of fantasists have to grapple and write against" ("Later Fantasy Fiction: Tolkien's Legacy" 335).

Doubtless, the continuing relevance of both authors speaks for itself. Alister McGrath points out in his biography of C. S. Lewis that all five bestselling books in America in the year 
1947 have almost passed into oblivion, stocked only by "second-hand, specialist dealers" (C. S. Lewis: A Life 367), whereas books by Lewis and Tolkien can be found in most bookshops, and have enjoyed resurgences thanks to various film versions and biographies over the years. Their fantasy fiction, despite any acclaim or disdain from any quarter, academic or otherwise, clearly has some inter-generational staying power which makes it worthy of notice.

\section{The Early Years}

As their theistic imagination provided the context for the creation of their most wellregarded fantasies, it is important to establish the role of Christianity and religious belief throughout the lives of Tolkien and Lewis. John Ronald Reuel Tolkien was born in January 1892 in Bloemfontein, South Africa, where he lived with his family for four years before they moved back to England after the death of his father. His mother died in 1904, leaving Tolkien and his brother Hilary in the care of Father Francis Xavier Morgan, a local parish priest and close family friend, whose involvement in Tolkien's life as benefactor was crucial after such a painful blow to the family. It says much of Mabel Tolkien's influence and Tolkien's twelve-year-old understanding of her faith that he would later write: "My own dear mother was a martyr indeed, and it is not to everybody that God grants so easy a way to his great gifts as he did to Hilary and myself, giving us a mother who killed herself with labour and trouble to ensure us keeping the faith" (as quoted in Carpenter's J.R.R. Tolkien: A Biography 31). His faith, being deeply rooted at such an early age, was of lifelong importance to him. His love of languages began in his childhood, where he dabbled in the creation of various languages of his own, and he went on to study Finnish, English etymology, and Middle-English at university. After one failed attempt in 1909, Tolkien received a scholarship to Exeter College in Oxford and began university there in 1911. Like so many of his contemporaries, he fought in the First World War, at the Battle of the Somme in 1916, some short months after his marriage to childhood sweetheart Edith Bratt. In between active service and convalescence, he continued to work on various mythologies, which would become recognisable as part of the Middle-earth legendarium. After the war, he worked as a philologist and etymologist for what would become the Oxford English Dictionary. Tolkien's formal academic career began in 1920 when he began work as a Reader in English Language at Leeds University, where he was appointed Professor of English Language in 1924. Other work from this pre-Oxford period between 1920 and 1925 include early drafts of his translation of Sir Gawain and the Green Knight, and his own work Farmer Giles of Ham, The Fall of Arthur, and Lay of Leithan, the last of which is supposed to be the first of his works that C. S. Lewis read and critiqued. Tolkien's children during that time had also inspired his fatherly tales of Roverandum, told on a Yorkshire holiday about a toy dog (it was posthumously published by his son in 1995), 
and the Father Christmas Letters (published in 1976), which became an illustrated Christmas tradition for his growing young family from the year 1920, when his eldest son John was three. In 1925, he left Leeds to take up an appointment as Rawlinson and Bosworth Professor of Anglo-Saxon at Oxford. It was here that his friendship with C. S. Lewis, and his career as a literary fantasist took off in earnest. Although Tolkien's forays in fantasy, myth and fairy story had been ongoing throughout his life, there was little public evidence of his writing until this era in Oxford.7 Many fragments of what is now collected in his posthumously published Middleearth legendarium were conceived and partially written up even before the birth of his children.

Clive Staples Lewis (known as 'Jack') was born in 1898 in Belfast Northern Ireland, where his happy childhood, described by himself as "the great continent of Atlantis" (Surprised by Joy 23), was abruptly cut short by the death of his mother in 1908. Part of this traumatic upheaval of his childhood was his removal, after her death, to various boarding schools which he despised. In 1914 he was under the care of private tutor W. T. Kirkpatrick. It was with Kirkpatrick that Lewis first developed a lifelong love for the classics and learned to prize a logical argument above all else. Wilson writes, "With Kirk he had felt the Romance of Ideas and the excitement of dialectic" (loc. 1427). He began studies at Oxford on a scholarship in 1917 (the year in which he also enlisted to fight in World War One), completing his studies afterwards in Greek and Latin Literature, Philosophy and Ancient History, and English. He worked as a philosophy tutor at University College after the war until 1925, when he was elected Fellow of Magdalen College, Oxford, and served there as a tutor in English Language and Literature.

Because Lewis spent much of his later life with a public profile as a Christian apologist, it is worth noting that he had been a firm atheist in his earlier life. In his early teens, he had found a fellow thinker in his tutor Kirkpatrick whose atheism presented "fresh ammunition for the [atheist] position [Lewis] had already chosen" (Surprised by Joy 114), and Lewis abandoned the faith of his childhood. Yet Lewis records a great sense of admiration for the holiness he found in some of his favourite authors, such as W. B. Yeats, whose works deeply impressed Lewis with the validity of a worldview outside of materialism and rationalism (141), even though rationalism was a view that he had prized in himself and in Kirkpatrick at the time. Among the writers Lewis acknowledged as having influenced him was Christian fantasist George MacDonald. Lewis characterised his first experience of MacDonald as the night that his "imagination was, in a certain sense, baptised" (146). MacDonald's Phantastes (1858) brought Lewis into contact with "a new quality, the bright shadow" which he deemed to be "Holiness"

\footnotetext{
${ }^{7}$ His poem "Goblin Feet" was published in Oxford Poetry 1915, one of the first (if not definitely the first) of his creative works to be published. Others have been lost and republished posthumously in The Book of Lost Tales.
} 
(Surprised by Joy 145). Another person instrumental to Lewis's conversion was Tolkien himself. Tolkien would later compare Lewis to a kind of midwife to his writing The Lord of the Rings, while Lewis biographer Alister McGrath proposes that Tolkien similarly played midwife to Lewis's conversion to Christianity (C. S. Lewis: A Life 130), via a now-renowned conversation between Lewis, Tolkien, and mutual friend Hugo Dyson regarding the nature of "true myth" in September 1931. Lewis would later describe himself as "the most dejected and most reluctant convert in all England" (Surprised by Joy 182) when he converted to "Theism, pure and simple, not to Christianity" in 1929 (184), what Wilson calls "a recognition that God was God" (loc. 2068). Lewis came to theism and then later to Christianity through his love of mythology and story, converting to Christianity in the time he was at Oxford. Perhaps the reason readers are so interested in finding evidence of Lewis's theism in his literature has come from the knowledge that his own conversion was largely shaped and inspired by the influence of Christian literature and literary thinkers. But such was the power of that idea of true myth: it meant acceptance on some level of the idea that all myths echo, and therefore partially represent, the Christian myth - "but with this tremendous difference that it really happened" (Lewis, Collected Letters: Volume I 976-77). This conversation demonstrates the deep and abiding love Tolkien and Lewis shared for mythology (whether Judeo-Christian or pagan), and for the medieval and Norse epics and romances that would have been familiar to them from their studies of Ancient and Anglo-Saxon mythologies.

\section{Oxford Years: Inklings and Public Reception}

Tolkien and Lewis owed part of their success to the circle known "informally and halfjestingly" as the "Inklings" (Carpenter, The Inklings xiii). ${ }^{8}$ Formed in their Oxford days before the publications of any major works, the group had a shared interest for a sort of "pre-Christian paganism [...] the anima naturaliter Christiana [a naturally Christian soul], a kind of natural mythology" as Colin Duriez and David Porter describe it in The Inklings Handbook (3). Duriez and Porter plot the timeline of the Inklings as officially existing between the years 1933 and 1949. Tolkien created the group in order to persuade his colleagues of the worthiness of Icelandic and Old Norse sagas with regard to a proposed syllabus reform (The Inklings 27). Finding a common love for Norse mythology in Lewis, when they began to gather informally in 1929, Tolkien ventured to show to Lewis a poem he'd written about two original characters named Beren and Lúthien. They met at various pubs once or twice weekly to discuss various writing projects. Wilson records Inklings recruit John Wain's impression of those Thursday

8 So-named after an undergraduate group of the same name disbanded, allowing the name to be appropriated for the Tolkien and Lewis group. 
evening meetings: that they were "'as good as anything [he would] live to see.' He was intoxicated by the sense of having 'a circle of investigators, almost of incendiaries, meeting to urge one another on in the task of redirecting the whole current of contemporary art and life"' (C. S. Lewis: A Biography loc. 3874). Other regular attendees included Lewis's elder brother Warnie, Tolkien's son Christopher, Owen Barfield, Charles Williams, Roger Lancelyn Green and Hugo Dyson. Each member had a unique interest and expertise to contribute. Barfield, for example, was further known as a literary critic, poet, and a kind of Christian anthroposophist. Williams's reputation was for his skill at writing novels of a supernatural or thriller persuasion, plays, and books on the subject of theology and of literary criticism. Although many of the works for which Tolkien is now most renowned were published after the regular meetings of the Inklings ended, its members had heard and commented on various drafts of Tolkien's The Hobbit, The Lord of the Rings, and some of the mythology which would eventually be posthumously published by his son in The Silmarillion (1977). Lewis also presented pieces he was working on and publishing before the group more-or-less disbanded in 1949. These works included Lewis's The Problem of Pain (1940), his Space Trilogy - Out of the Silent Planet (1938), Perelandra (1942), and That Hideous Strength (1945) - and the first drafts of The Great Divorce (1945). The group fostered stimulating discussion and frank critique, such that much of what they wrote in those years would go on to become the most renowned publications of the Inkling authors. Three of the stalwarts (Charles Williams, Lewis, and Tolkien) dedicated a published work to the group. ${ }^{9}$ What united them was a common love for stories and the Christian beliefs they brought to bear upon their writing. While it is not within the scope of this research to analyse the influence of the group upon each other in depth, ${ }^{10}$ it is relevant to this study to note the convergence of interests and literary influences upon Tolkien and Lewis, both without and within the Inklings circle. Naturally, their common convictions would influence their various fantasies, and their shared theology. Tolkien, a family man and a scholar, was known to suffer from a lack of time and motivation for work on his epic, and the persistent interest of his fellows, like Lewis, and his son Christopher (to whom he sent chapters in the post) would prove invaluable. Tolkien was later (in 1965) to write of Lewis that

The unpayable debt that I owe to him was not 'influence' as it is ordinarily understood, but sheer encouragement. He was for long [sic] my only audience. Only from him did I ever get the idea that my 'stuff' could be more

\footnotetext{
9 Dedications included: Lewis's The Problem of Pain in 1940, Charles Williams's The Forgiveness of Sins in 1942, and the first edition of Tolkien's The Lord of the Rings saga, The Fellowship of the Ring in 1954, though the group had petered out by that time.

10 See Carpenter's The Inklings (1978), Gareth Knight's The Magical World of the Inklings (1990), Duriez and Porter's The Inklings Handbook (2001), Diana Pavlac Glyer's The Company They Keep: C. S. Lewis and J. R. R. Tolkien as Writers in Community (2007), and Philip and Carol Zaleski's The Fellowship: The Literary Lives of the Inklings (2015) - although the slant of these works is more biographical than critical.
} 
than a private hobby. But for the interest and unceasing eagerness for more I should never have brought The L. of the R. to a conclusion. (Letters 362)

Lewis himself commented in a letter to a Francis Anderson in 1963:

I don't think Tolkien influenced me, and I am certain I didn't influence him. That is, didn't influence what he wrote. My continual encouragement, carried to the point of nagging, influenced him v. much to write at all with that gravity and at that length. In other words I acted as a midwife not as a father. The similarities between his work and mine are due, I think, (a) To nature temperament. (b) To common sources. We are both soaked in Norse mythology, Geo. MacDonald's fairy-tales, Homer, Beowulf, and medieval romance. And, of course, we are both Christians (he, an R. C. [Roman Catholic]). (Collected Letters 1458)

Lewis was the first of the Inklings group to become well known for his writing. His conversion is notable for the effect that it had on his public life: his newfound faith became an inseparable part of his reputation. Lewis began writing and speaking about the tenets of Christianity, taking up the role of a public apologist for Christianity. This began with the publication of his book The Pilgrim's Regress: An Allegorical Apology for Christianity, Reason and Romanticism in 1933. And although he published his less well remembered science-fiction trilogy (published in 1938, 1943, and 1945), it was The Problem of Pain (1940) (and broadcast talks it led to for the British Broadcasting Corporation in 1941) that propelled him into the public eye. These talks established Lewis as one of the most well-known evangelists of his day, and as a skilled populariser of orthodox theology. As he himself writes in the preface to the publication of his Broadcast Talks (1942), his appeal lay firstly in being "a layman, not a clergyman; and secondly, because I had been a non-Christian for many years. It was thought that both these facts might enable me to understand the difficulties that ordinary people feel about the subject" (5). He intended to speak only about what was common to all Christians, attempting "to put nothing into the [...] talks which all Christians of all Churches do not agree with" (5). From there began his career as a popular theologian for the layman and the sceptic. The books for which he is, arguably, most famous, the series of children's fairy tales known as The Chronicles of Narnia, came after his reputation both as a writer of fiction and as a Christian apologist had been well-established.

The chronology of Lewis's publications is notable because the culture of England at the time was increasingly removed from a unified 'Christian' society. Writing about the religious landscape post-WWII, Grace Davie, in Religion in Britain Since 1945: Believing Without Belonging (1994), claims that there is "no getting away from the fact that the drifting of belief away from anything that might be termed orthodoxy [was] a major challenge to the contemporary churches" (xii). As Davie observes, the post-war period was one of "profound economic, social and political changes in British society", one which saw the "influx of immigrants [...] not all of 
them from Christian countries" which created an irreversible "trend towards greater religious diversity" and secularism (3). The modern move toward secularism might even be said to have been in evidence even before the Great War: G. K. Chesterton ${ }^{11}$ published his book on Orthodoxy (1908) precisely to address what he perceived as a contemporary challenge to Christian belief (as defined by the Apostle's Creed). Outside the church, faith-based religion lost influence, giving momentum to the rise of secularism in Great Britain. Societies such as the Rationalist Association in the United Kingdom (founded in 1885) and the rationalist movement were generally increasing in membership and notable publications. The Thinker's Library (1929) featured agnostic and atheist writers such as Joseph McCabe and J. B. S. Haldane, a later critic of Lewis. A distinction came to be made between belief and 'practising' religion on the one side, and 'nominal' Christianity on the other, and thus the church failed to "maintain regular contact with the majority of the people in the country" (Davie 42), or to connect with people who had previously been regular churchgoers. Davie describes it as an "increasingly evident mismatch between statistics relating to religious practice and those which indicate levels of religious belief' (4, emphasis added). Thanks to secularism, Christian churches experienced a loss of political influence: the authority of the church to speak on the issues of the day was eroded,12 as "ecclesiastical reconstruction [...] was superseded in the 1960s by far more radical approaches to change" (4). The World Wars led to the position of the church in relation to the state becoming a subject intensely debated, as the church's judgement was entwined with political decisions. Hugh McLeod notes in The Cambridge History of Christianity (2006) that personal experience of "the horrors of the war [...] also led to mass disillusion" (11), which further eroded the status of the church. This "secularisation" meant a "loss of faith in purely human solutions to human sufferings"13 (11). At the same time, it also prompted the unification of the various branches of Christianity against what was seen as the "common threat" (10) - the deChristianising of Great Britain.

Tolkien and Lewis bucked this trend, demonstrating evidence not only of a committed belief and regular practice, but also an assumption that this should be the natural posture of any person claiming to be a believer. Orthodox religious belief was being undermined from within, too, which is perhaps the reason Tolkien and Lewis especially saw themselves as vivid

${ }^{11} \mathrm{G}$. K. Chesterton was a noted influence upon Tolkien's imagination, as well as Lewis's, though to a lesser extent for Lewis whose main inspiration was George MacDonald.

12 This was a notable swing in the opposite direction, for previously, during The Great War, or World War I, many churches both in England and in mainland Europe attempted to provide religious justification for the war, as Michael Snape notes in his chapter on "The Great War" in Hugh McLeod's The Cambridge History of Christianity (2006).

${ }^{13}$ At this point, two of Lewis's doctrinal works, Mere Christianity (1952) (a non-denominational text on the fundamentals of Christian belief), and The Problem of Pain (1940) (an examination of suffering in the world), seem quite neatly to position themselves as direct responses to these trends. 
exceptions in a theological environment represented by the 'demythologisers' within the church. The influence of secular speakers such as Joseph McCabe and Ernest Renan, who undertook lecture tours and published controversial books questioning the divinity of Jesus, began to affect church teachings. A key figure was German New Testament scholar Rudolf Bultmann, whose extreme scepticism about the historicity of parts of the Bible demonstrates just how tenuous the church's hold on orthodoxy was becoming in the modern post-war world. According to Michael Nelson, author of "C. S. Lewis and his Critics," Lewis identified (and personally took upon himself to attack) a strand of liberalism that sought to "question the veracity of the Gospels, [...] eschew the miraculous, [...] [and which] dilutes the teaching of the faith" (8). Tolkien and Lewis were therefore cast as reactionaries to the revolutionary new inclination to 'demythologise' theology, a threat to belief which was coming from within the Christian community. This denial of the divinity of Christ and of the miraculous drove Lewis to champion a brand of orthodoxy which was, in Nelson's words, "fervently reinvigorated by reason, logic, and certainty in an age when those qualities usually are regarded as enemies to religion" (11). The 'dechristianisation' of both Great Britain, and the church to some extent, offers great insight into the climate into which Tolkien and Lewis were writing.

Notwithstanding the secular spirit of the times, Tolkien and Lewis were able to assume that religious conviction was something with which the broader public was, nominally at least, familiar.

Their approach to writing was therefore grounded in similar concerns, not only for creativity but also for theology. When Tolkien's first novel, The Hobbit, was published in 1937, Lewis praised the book in a review for the Times Literary Supplement, categorising it as "belong[ing] to a very small class of books which have nothing in common save that each admits us to a world of its own - a world that seems to have been going on before we stumbled into it but which, once found by the right reader, becomes indispensable to him" (Scull and Hammond 398). For Lewis, this class of books included Lewis Carroll's Alice's Adventures in Wonderland (1865), Phantastes (1858) by George MacDonald, and The Wind in the Willows (1908) by Kenneth Grahame - all well-established favourites by that time. He deemed it successful in uniting "a number of good things never before united [...]: a fund of humour, an understanding of children, ${ }^{14}$ and a happy fusion of the scholar's with the poet's grasp of mythology" (399). While Tolkien was a poor judge of the merits of his own writing ${ }^{15}$ - and even confessed in 1954,

${ }^{14}$ Given Lewis's earlier declared lack of interest in what is suitable for children, this assertion of knowing of what does appeal to children is significant.

${ }^{15}$ In 1957 Tolkien sold working papers of The Hobbit, The Lord of the Rings, Farmer Giles of Ham, and Mr. Bliss to William Ready of Marquette University in the United States for $£ 1500$, which price Scull and Hammond deem "a bargain in today's market, even adjusting for inflation; but Tolkien was satisfied with 
just after the publication of his second novel, The Fellowship of the Ring, "I do not expect, and did not expect, many to be amused by hobbits, or interested in the general story and its modes" (Letters 184) - his mythology resonated among the wider 'de-Christianised' public. When the reviews began to come back after the publication of The Hobbit, they turned out to be wholly positive. The novel was nominated for the Carnegie Medal for outstanding book of the year in 1937, and won the New York Herald Tribune Children's Spring Book Festival contest for best children's book in 1938.

Not long after the publication of The Hobbit, Lewis would go on to publish his own fantasy fiction. The first substantial work of fiction that Lewis ever attempted (and it was with the approval of the Inklings who thought it an exciting serial) was Out of the Silent Planet (1938). It was the beginning of what would become a trilogy of theistic, space-travel fantasy stories. Tolkien himself undertook to write a letter of recommendation to his own publisher Stanley Unwin in 1938, who was considering Lewis's manuscript for publication, praising it as "an exciting serial" that was read aloud to the Inklings and "was highly approved" (Letters 29). Out of the Silent Planet made its debut to mixed reviews. Reviews of its sequel, Perelandra, or Voyage to Venus (1943), were aware of the book's theological overtones. And yet, writes Walter Hooper, "many who disagreed with his Christian orthodoxy nevertheless like the book" (C. S. Lewis: A Complete Guide to His Life and Works 229), and find much to be admired in its lofty and imaginative scope. By the time That Hideous Strength (1945) completed the trilogy, the reviewers were divided: some praised Lewis's "too many exceptional gifts" (240), and acknowledged that he wrote "admirably and excitingly" (239), sounding "a militant call to battle" (240), while others lamented "unconvincing" characters and an "allegory [that] becomes too friendly" (239). This divide foreshadowed the two passionate camps of Lewis readers in years to come.

A memoir written by one of Lewis's contemporaries at Oxford, Sheldon Vanauken, gives a good account of one camp: a first encounter with these books which rather sums up the response Lewis hoped to evoke in his audience. In A Severe Mercy (1979), Vanauken recollects that when he and his wife came to Oxford in 1950, they found their long-held view of Christians and Christianity challenged. "Our fundamental assumption," he writes, "which we had been pleased to regard as an intelligent insight, had been that all Christians were necessarily stuffy, hide-bound, or stupid - people to keep one's distance from" (Vanauken 77), and subsequently

the amount" (Scull and Hammond 178). A few years later "\$2500 for an unsigned first edition of The Lord of the Rings [was] perhaps a good benchmark (twenty years later, the same copy might bring four times that amount)" (178). 
their community of "highly intelligent, civilised, fun to be with" Christian friends (77) caused them to revise this idea. Of his first encounter with the Space Trilogy, Vanauken explains:

I chose to read that C. S. Lewis science fiction trilogy first, for, apart from being beautiful and enthralling, it made me conscious of an alliance with him: what he hated (That Hideous Strength) I hated and feared. Much more important, perhaps, the trilogy showed me that the Christian God might, after all, be quite big enough for the whole galaxy. Nothing was proved except that, quite reasonably, He might be big enough; but, in fact, an insuperable difficulty - that of Christianity's being only a local religion - was overcome. (84)

This is surely the way Lewis meant his fiction to reach his audience, by reaching out first to their imagination (as Tolkien and Dyson had done for him in their discussions of true myth). Thus, Lewis became one flagship individual who demanded that Christianity be given serious consideration. According to Vanauken, Lewis

was perhaps the most brilliant and certainly the most lucid mind we ever knew: he wrote about Christianity in a style as clear as spring water without a hint of sanctimoniousness or vagueness or double-talk, never suggesting anything be accepted on other than reasonable grounds. He gave us, simply, straightforward, telling argument laced with wit. And that incredible imagination. [...] If minds like St. Augustine's and Newman's and Lewis's could wrestle with Christianity and become fortresses of faith, it had to be taken seriously. (85)

Lewis was becoming, not only for Oxford - which, as has been seen, had its own somewhat thriving and thinking believing community - but also for the general public, something of a gateway into the experience of Christianity.

As I shall argue in what follows, Tolkien and Lewis wrote vastly different fantasies under the banner of a single aesthetic technique. After all, it is a well-documented fact that they greatly influenced each other. From Tolkien's praise of Lewis's fiction, it is clear that those things he most admired in Lewis's writing were the very objectives he pursued in his own. In his letters of recommendation for the Space Trilogy, Tolkien declares himself "so enthralled that I could do nothing until I had finished it" and that his first criticism "was simply that it was too short" (Letters 32). Although he has some reservations - he cites Lewis's proclivity for "rather creaking stiff-jointed passages" (32) (passages that have since been corrected) - he goes on to say:

I realise of course that to be even moderately marketable such a story must pass muster on its surface value [...] I thought Out of the Silent Planet did pass this test very successfully. [...] But I should have said that the story had for the more intelligent reader a great number of philosophical and mythical implications that enormously enhanced without detracting from the surface 'adventure'. I found the blend of vera historia with mythos irresistible. (33) 
That Tolkien, who was known by then for the success of The Hobbit, would recommend a book, and in such glowing terms as might later be ascribed to his own chef-d'oeuvre is high praise indeed. And although he touts it as a book he would have bought "at almost any price", he rather sardonically remarks that "my taste is not normal" (34). Lewis's praise of the near-finished product of The Lord of the Rings focused on its "sheer sub-creation" (a term coined by Tolkien) and "gravitas" (Collected Letters: Volume II 990). His observations are evidence of a shared artistic outlook that ran deep. Lewis praises the "merciless piling up of odds" pitted against the "sickness of hope deferred" (990), and how confidently such a romance could "repel the charge of 'escapism"' (990), where "victory is as transitory as conflict" (990-1). And while he hints at the existence of passages that he personally would change or omit, he writes, "[i]t will rank, along with the Aeneid as one of what I call my 'immediately sub-religious' books" (991). Both authors were equally free in their negative critique. It is a well-known fact that Tolkien thought of Lewis's Narnia books as something of a hodgepodge of various mythologies - indeed, Francis Spufford in The Child that Books Built: A Life in Reading (2002) describes Tolkien "with his carefully accumulated elvish etymologies" as "scornful" (101). Tolkien once warned Lewis, "if you bore me, I shall take my revenge. (It is an Inkling's duty to be bored willingly. It is his privilege to be a borer on occasion)" (Letters 128). Roger Lancelyn Green recalls a conversation with Tolkien in which Tolkien, on hearing Green had also been reading Lewis's new Narnia books, remarked “I hear you've been reading Jack's children’s story. It really won't do, you know! [...] Doesn't he know what he's talking about?" (Green and Hooper, C. S. Lewis: A Biography 241). Wilson offers an explanation of this: he says that "Tolkien's aesthetic objection to the Narnia stories is a perfectly valid one if we attempt to judge Narnia by the standards of The Silmarillion" because "Lewis's books for children show signs of extraordinary haste in composition; they are full of inconsistencies, and by his [Tolkien's] standards they are not even particularly well-written" (loc. 4045). Wilson goes on to say that

[t] he fact that Lewis threw into the mixture all the things which immediately concerned him certainly makes for a most imperfect 'sub-creation' by Tolkien's strict standard; but it is symptomatic of the much more important fact that in the Narnia stories Lewis is deeply and unselfconsciously engaged in the stories he is creating. He has abandoned here a cerebral and superficial defence of religion [...]. He has launched back deep into the recesses of his own emotional history, his own most deeply felt psychological needs and vulnerabilities. It is this, surely, which gives the books their extraordinary power. They are written white-hot. (loc. 4088)

Tolkien would never allow his work to be written in such a way. Their mutual critique and encouragement from those formative years with the Inklings had its payoff, however, for the 1950s saw the publications of the works for which both authors are today best-known: Tolkien's three volumes of The Lord of the Rings, and Lewis's seven Chronicles of Narnia. 
Before he began writing the Chronicles, though, Lewis had already established himself as a popular apologist, and the change of direction to fantasy literature came as something of a surprise. Some critics, such as Wilson and Spufford, have connected this change to Lewis's reaction to a debate he took part in with Elizabeth Anscombe at the Oxford Socratic Club. The club had been "founded with an aggressively Christian purpose" (Wilson, loc. 3298), and Lewis was a central member whose manner of argument was often controversial. Indeed, some biographers suggest that the Socratic Club's debates showcased Lewis at his very worst. Wilson writes that " $[t]$ he vigour of the sentiment, as so often in Lewis, disguises the unfairness of the argument" (loc. 1510), and that "[n]o one who witnessed these debates has ever suggested that Lewis played fair" (loc. 3301). Anscombe, however, no "naïve nonbeliever, but an extremely sophisticated twenty-eight-year-old student of Wittgenstein's who also happened to be a committed Roman Catholic" (Spufford, 98), took Lewis on, and "trounced” him (98). Lewis had recently published an argument, in Miracles (1947), that the existence of human reason presupposes something beyond the human, which for him was an argument for God. Though Anscombe herself believed "that beyond the natural world lay the God who created it" she also believed that "until a better argument than Lewis's came along, there would be no guarantee" (99). The strength of her undaunted argument left Lewis "flustered", resorting to describing the cause as "magic" (99), and embarrassed. Opinions vary amongst biographers as to just how much this experience affected Lewis's confidence. Wilson, for one, believes that Lewis went from "bullying hero" to "a child, a little boy who was being degraded and shaken by a figure who, in his imagination, took on witch-like dimensions" (Wilson, loc. 3840) (and from which Wilson believes Lewis takes inspiration for certain episodes in his Narnia books). Taking his cue from Wilson, Spufford speculates that when "the intellectual carapace of his belief stripped away in public by a powerful woman," Lewis felt "like a child caught out in a game of makebelieve" (Spufford, 98). His "intellectual justification gone" (99), Lewis seemed to lose confidence in his ability to argue for God. This childish make-believe, however, at least for Wilson and Spufford, seemed to suggest the answer.

Wilson records that Lewis began to think that

make-believe was really another way of talking about the reality of things; unless the brutal and cerebral way in which grown-ups tried to come to conclusions about the world was not the only way; unless he could explore the way of Phantastes - in which another world opens up to the Dreamer through a piece of bedroom furniture. The seeds of the first Narnia story were dawning in his mind. (loc. 3847)

Lewis did not attempt another apologetics book (although he did revise sections of Miracles and Mere Christianity for future editions), as he "he came to feel that their method and manner were spurious. There must be another way 'further up and further in'” (3847). Interestingly, he did 
not abandon his argument so much as change form, as if his conviction remained steady but he began to approach the expression of it with far more humility. Wilson suggests that at this point Lewis felt "that there were other, and better, ways of telling the truth than by means of argument" (loc. 3912). "Whereof we cannot speak," muses Spufford, "thereof we must write children's books" (99).

Despite the evident significance of this episode in Lewis's life, the degree to which it turned Lewis into a bruised man, a "despondent conservative" (Wilson, loc. 4075), is uncertain. His diaries and letters show a proclivity for fantasy and world building long before the Anscombe debate, with many of the images, such as dreams of lions and the image of a girl meeting a faun in a snowy wood, predating many of his published works. He defends his choice of writing for children in his fittingly named "Sometimes Fairy Stories May Say Best What's to be Said" published in 1956. It seems likely, at least, that as he assessed his apologetics career, the debate gave Lewis the impetus to begin work seriously on writing those images into story. ${ }^{16}$

\section{Later Years: Reception}

Amongst their peers at Oxford, the public reception of fiction by Tolkien and Lewis from the 1950s onward appeared to have been divided, especially for Lewis. Tolkien's work experienced immediate and unequivocal popularity, despite high-brow responders forecasting its support would be short-lived. ${ }^{17}$ By contrast, when Tolkien championed Lewis for various positions in the university, he was very much surprised by the "extraordinary animosity" against Lewis within the English faculty (243). As McGrath observes:

Fame may have raised Lewis's profile, but in the first place, this just made him a more obvious target for those who disliked his religious beliefs. And in the second, many of his academic colleagues came to believe that he had sold out to popular culture to secure that fame. He had sold his academic birthright for a populist pottage. (242)

${ }^{16}$ Certain sections of his fiction do seem to owe a debt to this debate, as various scenes (not least the children's response to the enchantments attempted by the Green Witch in The Silver Chair) seem to be a re-imagination of this debate. When the children and Puddleglum find themselves unable to prove (and increasingly unable to remember) the world above her under-ground lair, Puddleglum finally retorts "I'm on Aslan's side even if there isn't any Aslan to lead it. I'm going to live as like a Narnian as I can even if there isn't any Narnia" (The Silver Chair 156-7). While some might see in the Lady of the Green Kirtle a defamiliarised episode of Lewis's failure to debate with Elizabeth Anscombe - Wilson speculates that " $[t]$ he moment when the Witch traps the children underground and tries to persuade them that there is no world above the ground as they supposed, is a nursery nightmare version of Lewis's debate with Miss Anscombe" (loc. 4065) - some others, such as Adey, see a simpler defamiliarisation of "Lewis's subjection to Mrs. Moore" when "Prince Rilian laments his ten-year subjection to the Witch as surrogate mother" (187). Though Adey calls it a game of "dated academic psychoanalytical reductionism" to dwell on such connections (193), it would be remiss not to mention them.

${ }^{17}$ As noted by Wayne G. Hammond in his article "The Critical Response to Tolkien's Fiction" (1996). 
Indeed, amongst his peers, the dislike of Lewis grew to such an extent that when the first reviews of Tolkien's The Fellowship of the Ring came out in 1954 with a recommendation from Lewis, Tolkien wrote to his publisher that they may have done better not to have "got involved at all with the extraordinary animosity that C. S. L. seems to excite in certain quarters" (Letters 184). Despite this, Lewis was drawing a significant following in both Great Britain and in the United States as an apologist for the faith, thanks to his wartime broadcast talks on the subject of Christianity, and the publication of books such as The Problem of Pain (1940), Mere Christianity (1952),18 and the satirical and unique The Screwtape Letters (1942), which Lionel Adey has called "more amusing and more psychologically penetrating than any of Lewis's other fiction for adults, except for his Great Divorce and Till We Have Faces" (C. S. Lewis, Writer, Dreamer, and Mentor 147), the latter of which (along with Perelandra) he deems "most deserving of survival" in the literary canon (278). In McGrath's eyes, Mere Christianity “consolidated Lewis's reputation as a popular Christian theologian - someone who was able to communicate the themes of the Christian faith in an intelligent and accessible way" (217). Indeed, there is something almost vulnerably autobiographical in his description of the new Christian's potential experience of church: the horror of being now a part of the group which includes "the local grocer with an oily expression on his face" (Lewis, The Screwtape Letters 5), the "fanatical bridge-player" and the man who is "a miser and extortioner" (7), in fact "that selection of neighbours whom he has hitherto avoided" (6). It was this ambivalent handling of Christianity, which resulted in Lewis's being dubbed more than once the 'apostle to the skeptics'.

For those with an inclination to lionise Lewis, there is indeed ample opportunity. As Michael Nelson commented in 1988:

the Lewis devotee (and there are many, judging from the sales figures) could, upon rising, don his C. S. Lewis sweatshirt, ascertain the date from his C. S. Lewis calendar, make coffee wearing his C. S. Lewis apron and drink it from his C. S. Lewis mug, offer devotion to his Maker in the words of C. S. Lewis, and meditate on what C. S. Lewis had done on that date, before setting off to work or school with his C. S. Lewis tote bag filled with C. S. Lewis books. (2)

Nelson is realistic when he writes that "Lewis's boldness and outspokenness, which underlay so much of his success as a defender of the faith, spawned defects that were the excess of his virtues" (12), and notes that he was prone to "caricature and bully" those with whom he disagreed (12). This resulted in attracting "critics equal and opposite to his admirers in their passions" (13). One such was the renowned scientist, geneticist, biochemist, and mathematician J. B. S. Haldane. Occupying the equivalent public sphere in secularism that Lewis occupied for

${ }^{18}$ A revised version of The Case for Christianity (published in 1942). 
theism, Haldane, as an influential Darwinian thinker, strictly opposed Lewis's views and religion. His critique of Lewis first grew from a reaction to Lewis's science fiction novels in which Haldane found the science lacking, but his vitriol quickly became more apparent and more personal, eventually revealing religious differences to be at the heart of his animosity. His hostile essays against C. S. Lewis entitled "Auld Hornie, F. R. S." and “More Anti-Lewisite” (published in his 1951 book Everything Has a History) attacked first the worldview displayed in Lewis's Space Trilogy, and then Lewis's Broadcast Talks. ${ }^{19}$ In "More Anti-Lewisite" (1947) Haldane writes: "Lewisite is a poisonous liquid with a poisonous vapour" (259).

As early as 1974, Green and Hooper suggested that the critics of Lewis and his work "may be roughly divided into the sceptics and the sentimentalists" (C. S. Lewis: A Biography 255), targeting either his Christianity or the villainising of certain child characters, such as Edmund or Eustace (or Susan). "[T]hose who dislike," they continue, "do so very thoroughly and can see few virtues in the series - even condemning them as dull or badly written, condescending, cliché-ridden, devoid of any characterization" (255). Lewis still evinces such responses today. In fact, Nelson's conclusion that nonbelievers were the group subject to the most powerful responses to Lewis's writings, because "thousands (or tens or hundreds of thousands) have discovered truth or been duped, depending on the bias of the writer" (18, my emphasis), is shrewd. In identifying many of Lewis's other critics as academic theologians, Nelson reflected on whether their distaste stemmed from indignation for "an intruder on their turf, a layman writing about matters that the scholars' advanced degrees certify to be off-limits to the laity, and an extraordinarily popular and influential writer to boot" (14). That group's use of adjectives such as 'best seller', 'popular' and 'best known' were, for Nelson, indicative of "condescension and dismissiveness" (14). Even Churchill had an opinion and deemed Lewis's books "deliberately childish" (15).

Nevertheless, Lewis's books have remained popular with children and adult Christians, despite their being somewhat side-lined by the "astonishing success" of Tolkien's The Lord of the Rings, (indeed, its "cult status") during the 1960s (McGrath 366). Wilson ponders whether "[t]his phenomenon can only be explained by the fact that his writings, while being selfconsciously and deliberately at variance with the twentieth century, are paradoxically in tune with the needs and concerns of our times" (C. S. Lewis: A Biography loc. 36). He goes on to aphorise, "Though Lewis's cooking may be rough, you never forget its flavour" (loc. 3446). Adey writes that "[f]or all their imperfections, they [the Narnia books in this instance] constitute a

${ }^{19}$ As Lewis noted in his essay "A Reply to Professor Haldane", Haldane's rancour was for his worldview not his fiction, and would therefore be better directed against his apologetic texts, of which, by then, there were several. 
body of fiction worthy of their immense and sustained readership" (193). True, Lewis's works have continued to be controversial, although more recently the negativity has "been more subtle, perhaps in recognition that [Lewis's] reputation is too secure for light dealing" (Nelson 15). Perhaps the responsibility for the ongoing interest in Lewis may be put down to the efforts of his erstwhile secretary Walter Hooper who has carried the torch for Lewis, in much the same way that the late Christopher Tolkien did for his father, in publishing letters, manuscripts and various ephemera to keep the interest current in the minds of the reading public. Other notable events, McGrath notes, were the creation of various worldwide Tolkien and C. S. Lewis societies, and the publication of several biographies which began to appear shortly after the writers' deaths (in 1973 and 1963, respectively). The influence of the legendary Inklings group contributes, moreover, to a kind of cross-pollination of interests, so that the rise in popularity of one, like J. R. R. Tolkien, often results in a rise in interest for the others. Recently, Tolkien's cultural legacy has been affirmed and revisited with the release of the 2001-2003 Peter Jackson Lord of the Rings films, and later The Hobbit film trilogy in 2012-2014. Likewise, Lewis's reputation has received a boost from the CBS made-for-television animated film in 1979, the TV-serial of the Narnian chronicles by the BBC (1988-1990), ${ }^{20}$ and the Walt Disney Walden Media blockbuster remake of The Lion, the Witch and the Wardrobe in 2005 (and sequels ${ }^{21}$ ), as well as various radio and audiobook broadcasts. Both Middle-earth and Narnia franchises are moreover expecting a TV series reboot in upcoming years (by Amazon and Netflix respectively). Not without their occasional controversies, the fantasies of Tolkien and Lewis have retained public interest over seven decades - which in itself testifies to the success of their artistic methods despite the de-mythologisers.

\section{Modern Literary Criticism}

As I have already intimated, the focus of some of the critical (rather than popular) response to Tolkien and Lewis tends to glance off their fantasy fiction and ground itself in other of their published works. On Tolkien, a renowned medievalist who held two professorships at Oxford in his lifetime, and published essays and treatises in that capacity, there is a reasonably substantial output relating to his academic interests, though it is debatable whether such attention would have been afforded him without the popularity of his fiction. In his lifetime, Tolkien published only four novels in the Middle-earth legendarium, with a smattering of short stories and verse. Much of what is now available was posthumously published. Tolkien was

\footnotetext{
${ }^{20}$ These renditions included The Lion, the Witch and the Wardrobe in 1988, Prince Caspian and the Voyage of the Dawn Treader in 1989, and The Silver Chair in 1990.

${ }^{21}$ These included Prince Caspian in 2008, and The Voyage of the Dawn Treader in 2010.
} 
therefore a little less of a target for detractors because his academic work took him into specialist by-ways, whereas Lewis, writing on Milton for example, was more in the public eye, reaching a wider audience - he was known to be fairly opinionated and provocative. ${ }^{22}$ Due to Tolkien's preference for privacy, and because much of his published work (especially prior to his publication of The Hobbit) was academic, involving his philological interests and Middle English translations, Tolkien's reputation was probably protected from the over-familiarity that Lewis's critics are afforded by his being openly religious, provocative and occasionally brash in his commentary, lectures and talks, comments, his many essays, broadcasts, and published books. Although Christian belief was a recurring reference point for both Tolkien and Lewis in their fiction and their lives, there are other, seemingly more absorbing, aspects of their creative output which have drawn attention away from the plain study of their literature as story. Lewis's reputation was built first and foremost upon his being a public speaker for Christianity. ${ }^{23}$ He was certainly the more prolific author of the two, publishing 40 or so books in his lifetime including, fifteen volumes of fiction and 24 volumes of nonfiction - most of which were devoted to subjects of theology and practical belief, as well as literary history and criticism. Amongst his literary criticism were several important and influential works, such as The Allegory of Love (1936), A Preface to "Paradise Lost" (1942), and his history of English Literature in the Sixteenth Century (1954). His work on medieval and Renaissance literature The Discarded Image was published the year after his death in 1963. Of his academic legacy, Adey writes warmly of the appeal of "Lewis's fluency, incisiveness, wit, and power of apt and arresting illustration, not to mention the breadth and exactness of scholarship and historical imagination" that make these "among the most readable histories and The Discarded Image an unsurpassed introduction to medieval literature" (277). Lewis, however, was never afforded the title of Oxford professor. Eventually, in 1954, Cambridge University offered him the Chair of Medieval and Renaissance Literature. There are several studies on Lewis's academic contributions as a literary critic and historian, although as well as many essay-length appreciations in various anthologies.

As for Tolkien, Shippey has noted that one finds a "general phenomenon of intense critical hostility to Tolkien, [and] the refusal to allow him to be even a part of 'English literature"' (J. R. R. Tolkien: Author of the Century loc. 5121). It is true that fantasy literature, not

\footnotetext{
${ }^{22} \mathrm{~A}$ favourite anecdote from Humphrey Carpenter's The Inklings tells of Lewis's eccentricities, when, disdaining a student's refusal to admit the good qualities of Arnold's Sohrab and Rustum, "even after Lewis had chanted a hundred lines of it at him", Lewis apparently declared “'The sword must settle it!' and reached for a broadsword and a rapier which (according to J. A. W. Bennett who was there) were inexplicably in the corner of the room. They fenced - Lewis of course choosing the broadsword - and, said Bennett, 'Lewis actually drew blood - a slight nick"' (214).

${ }^{23}$ As Chad Walsh would later subtitle his biography: C. S. Lewis: Apostle to the Skeptics (1949).
} 
just Tolkien's, has experienced general dismissal in certain sectors, perhaps due to an apparent prejudice against fantasy fiction amongst many highbrow reviewers and critics. Despite this, there exists some very good literary criticism on Tolkien. Many responses have illuminatingly connected Tolkien's Middle-earth with his interests in other areas, namely philology, history, and medievalism as a means of engaging with his literary creativity. For example, Mary Salu and Robert T. Farrell's collection of essays entitled J. R. R. Tolkien, Scholar and Storyteller: Essays in Memoriam (1979) enriches discussion on his philology, Old Norse, Middle English, and Old English, makes comparisons with Chaucer, and intellectually engages with some of Tolkien's more expansive scholarly works. Tolkien had after all edited, and even made a verse translation, of Sir Gawain and the Green Knight and Ancrene Wisse, and had had a public lecture published as an essay on the subject, as Shippey notes in "Tolkien and the Gawain-poet" (1996). In 1982, Shippey wrote one of the first literary works on Tolkien, called The Road to Middle-earth, in which he pays considerable attention to Tolkien's philological interests and his engagement with the literature and epic poetry of the Middle Ages. Shippey suggests that Tolkien's creative works were a natural output for Tolkien's interest in inventing languages with their own histories and etymologies, and even his interest in cartography. The value of such works as these is their serious analysis of the process and influences on the creator, and contextualising the creation. Like Shippey, other Tolkien scholars have found in-roads to a literary analysis of Tolkien's work through the lens of his philology. Verlyn Flieger's book Splintered Light: Logos and Language in Tolkien's World (1983), for example, focuses on Tolkien's use of language, particularly in The Silmarillion, and is concerned to situate it in Tolkien's life, interests, and legendarium. In a similar vein, Mary R. Bowman’s “The Story Was Already Written: Narrative Theory in The Lord of the Rings" (2006) discusses Tolkien's narrative techniques, how he draws attention to the telling of the story and the experience of reading it. Though not quite germane to the argument made in this thesis, Ents, Elves, and Eriador: The Environmental Vision of J.R.R. Tolkien (2006), authored by Matthew T. Dickerson and Jonathan Evans, draws on Tolkien's environmentalist vision to demonstrate its influence on modern environmentalism whilst simultaneously connecting it to the ancient and current teachings of earthly stewardship in the Catholic church. ${ }^{24}$ Tolkien's love for trees rather invites environmental readings, many of which can be found in Tree of Tales: Tolkien, Literature, and Theology (2007) edited by Trevor Hart and Ivan Khovacs. John Garth, author of Tolkien and the Great War: The Threshold of Middle-earth (2003), compellingly reflects on the influence of the First World War on Tolkien's imagination,

${ }^{24}$ Dickerson's later work, Narnia and the Fields of Arbol: The Environmental Vision of C. S. Lewis (2008), coauthored with David O'Hara, is another good example of eco-critical readings of the Inklings' work, and one which also draws out themes of sustainability and stewardship as set forth in the Bible and church tradition. 
and how he used his writing not as escape but as a means to process the horrors and heroism he experienced there. As Tolkien has himself reflected in a letter to his son Christopher, who seemed to be undergoing similar despair in 1944,

I think also you are suffering from suppressed 'writing'. [...] I sense amongst all your pains (some merely physical) the desire to express your feeling about good, evil, fair, foul in some way: to rationalize it, and prevent it just festering. In my case it generated Morgoth and the History of the Gnomes. Lots of the early parts of which (and the languages) - discarded or absorbed - were done in grimy canteens, at lectures in cold fogs, in huts full of blasphemy and smut, or by candle light in bell-tents, even some down in dugouts under shell fire. (Letters 78).

His literary analysis of the Dead Marshes functions as a reminder, much like the battlefields of the Somme, of "all that has to be defied" (J. R. R. Tolkien: Author of the Century loc. 3767). While John Garth is the accepted expert on historical and lived experience influences on Tolkien's imagination, particularly in those formative years at the front, there are many other texts that exist, Humphrey Carpenter's biography not least, that have reflectively and meticulously traced the connections between Tolkien's life and work, grounded in historical and biographical context. As to other literary commentary, the enthusiastic engagement in fan journals is such that Wayne Hammond declares that these journals are the "backbone" of Tolkien literary commentary (Hammond 230): though not quite at a desirable level of sophistication, they prove, according to Hammond, the readiest outlet. The journal Tolkien Studies, beginning in the year 2004, has contributed much to the literary analysis of Tolkien's work, with contributions focusing on study of some of the more obscure characters and Middle-earth tales, and on comparing other of Tolkien's interest areas (such as Beowulf) to his legendarium. ${ }^{25}$

Some crucial works which have paved the way for the kind of aesthetic I propose are T. A. Shippey's J. R. R. Tolkien: Author of the Century and Alison Milbank's Chesterton and Tolkien as Theologians: The Fantasy of the Real (2009). Shippey's monograph admirably engages with Tolkien's Christian mythology not simply from either a popularist or Christian orientation, and certain of his discussions (that of the Dead Marshes and on the ambiguity of the Lord's Prayer in connection to the Ring) would qualify as analysis of defamiliarising techniques though he does not use the word. Milbank situates her theologically-informed discussion in the realm of literary creation. Although her conclusions tend toward the metaphysical and philosophical, this book has proved fundamental to much of the discussion that follows.

\footnotetext{
${ }^{25}$ Although there have been various handlings of his methods of 'sub-creation', a theory I return to in my next chapter, many of the dealings, such as in theological publications like First Things, tend to remain non-literary, inclined more toward the hagiographic or theological discussions.
} 
As for critical responses to Lewis's fiction, although it was generally received with enthusiasm by the public, the critical reception can tend to focus on the weaknesses of Lewis's fantasy fiction: the too-obvious allusions, the paternalistic tone and emphasis on Victorian morals for the children in the Narnia books, and so on. Authors such as David Holbrook, author of The Skeleton in the Wardrobe (1991), have suggested that the material in the Narnia books is unfit for children, being morally and stylistically objectionable. Adey contends that "Lewis's achievement as a storyteller was limited by over-hasty production and unwillingness to take his fiction as seriously as his major critical works" (192), and that he poses a "boyishly eager" opposite to "the perfectionist Tolkien" (192). Despite this, his children's books still enjoy a significant readership, and due to this there seems to be an assumption amongst critics that this kind of literature is too popular to be taken seriously. ${ }^{26}$ Lewis's fiction has merited the notice of a few literary critics, including Lionel Adey and Peter J. Schakel for example, who have contributed significantly to the study of Lewis's work, as well as Chad Walsh's The Literary Legacy of C. S. Lewis (2008) and C. N. Manlove's C. S. Lewis: His Literary Achievement (2010). Lionel Adey has provided a thorough critical overview of Lewis's fiction in his C. S. Lewis: Writer, Dreamer, and Mentor (1998), which is a valuable work in establishing the context of the writing of Lewis's work, even including his letters, as well as giving a thorough analysis of the literary influences on Lewis's work (not unlike Doris T. Myers's monograph C. S. Lewis in Context (1994)). Adey also provides a thorough overview (at the time) of the prevalent academic commentary and critique, asking what influence Lewis's books may have had or are likely to retain. There has been a trend amongst those who evaluate Lewis's fiction, however, to critique his doctrine to the point of neglecting a literary evaluation. Even Michael Nelson's article "C. S. Lewis and His Critics" cites little more critical engagement than an overview of the response of the clergy and theological academia. A fair amount of what criticism exists is 'interpretative' and not a sophisticated scholarly engagement with his fiction as literature (but rather treated as extended sermon illustrations). There is much more to be said of merit of the aesthetic of his fiction - something which Peter J. Schakel's monograph Reason and Imagination in "Till We Have Faces" (1984) attempts to address for at least that title.

If David Bratman in his chapter on "The Inklings and Others" must flag that he is making a "post-Tolkien assumption that fantasy is for adult readers" as late as 2014 (330), then there must be something about fantasy in general which still needs to be defended as more than 'just' for children. Bratman speculates that because “Tolkien's first published novel was released as a children's book, he has been pigeon-holed as a children's author in a way that Lewis, whose Narnian books were not his first, has not" (330). It is telling that Lewis has faced a similar 
dismissal to that suffered by Tolkien for his fantasy fiction, but curiously has been somewhat shielded from some of the disparagement that Tolkien even now faces, simply by virtue of the label of children's fiction that is attached to the Narnian Chronicles, in particular. Part of the disparagement of Tolkien fans - not "readers", as Patrick Curry sardonically notes (373) - is to write off both the fiction and the fans as childish. For instance, Patrick Curry demonstrates that many of Tolkien's detractors have - wrongly or simplistically - written off his fiction as "infantilism, nostalgia, escapism" (378). ${ }^{27}$ There is ongoing debate of how his fiction is to be categorised. In fact, the situation had got so out of hand, Curry notes, that public libraries shelved Tolkien's magnum opus The Silmarillion in the children's section, so "firmly affixed" was his children's literature label (330). Lewis's Chronicles of Narnia are accurately categorised as children's fiction but are nevertheless misread as simplistic parable by readers of all ages. His adult fantasy fiction, such as Till We Have Faces and The Great Divorce, therefore exist in a liminal space, as his work is most often separated into one of two camps: either Christian apologetics, or children's fantasy fiction. Commonly, Lewis is characterised as an apologist, or an apologist disguised as a children's fiction author, and scarcely anything more nuanced in between. I have personally seen Lewis's Space Trilogy inappropriately shelved in the children's sections of some bookshops, and fiction works like The Screwtape Letters and The Great Divorce lodged with his theological nonfiction. Both Tolkien and Lewis believed that fantasy was not just children's fare, and made this stance clear in the way that they approached their literature. Fantasy fiction's popularity with child readers is excusable, it seems, yet in adult fiction mass popularity appears to place fantasy "beyond serious consideration" (Curry 375). No doubt the works at stake have their limitations. But criticism to date has been reflective more of the personal views of the critic than of these limitations themselves.

Evidently, the prevalent critical dismissal of children's literature was something to be challenged, then as now, given the apparent prejudice against fantasy fiction that seems still to exist in some academic circles, and more broadly amongst certain reviewers and critics. Lewis declared in his essay "On Three Ways of Writing for Children" (first published in 1952), that "a children's story which is enjoyed only by children is a bad children's story. The good ones last. A waltz which you can only like while you are waltzing is a bad waltz" (59).28 In his eyes, any literature that could not be enjoyed in adulthood as well as in childhood was not worth reading in the first place. Let us not forget that Tolkien, in his way, demonstrated his agreement with

\footnotetext{
${ }^{27}$ Scull and Hammond cite a particularly disparaging review which called The Hobbit "insufferably arch, suffused with bogus winsomeness of a pampered child at a fancy dress party" (Scull and Hammond 400), and Edmund Wilson, in "Oo, Those Awful Orcs" (1956) lamented the British appetite for such "juvenile trash" (Scull and Hammond 500).

${ }^{28}$ The irony of this statement must be acknowledged, that many of Lewis's own readers would no longer enjoy his children's fiction as adults, once they saw its religious overtones.
} 
this sentiment by publishing a 1000-page fantasy for adults, proving to fans of The Hobbit that fantasy was not just for children; The Lord of the Rings has been heralded by booksellers as the greatest fiction of that century or millennium (Curry 373 ). The reasonably recent explosion of academic interest in children's literature, however, has prepared the ground for more sophisticated or serious critique.

Moreover, Tolkien's work is a theistic text, as many scholars are aware, but in a more subtle way than Lewis's. As Humphrey Carpenter writes in his biography:

Tolkien cast his mythology in this form because he wanted it to be remote and strange, and yet at the same time not to be a lie. He wanted the mythological and legendary stories to express his own moral view of the universe; and as a Christian he could not place this view in a cosmos without the God he worshipped. At the same time, to set his stories 'realistically' in the known world, where religious beliefs were explicitly Christian, would deprive them of their imaginative colour. So while God is present in Tolkien's universe, He remains unseen. (91)

Nevertheless, the connection between Tolkien's mythology and his theology was obscure enough that Verlyn Flieger wrote (in 2014), Tolkien's fantasy has been "appealing equally to neo-pagans who see in its elves and hobbits an alternative to the dreary realism of mainstream culture" ("But What Did He Really Mean?" 149), including mainstream religion. This may be because Tolkien was "ambiguous, even contradictory, in stating his own position" (149). Significantly, Flieger says, Tolkien "opens the door to both" orthodox and pagan views (151), and it is precisely this "creative tension" (162) with Christianity which "contain[s] paradox without resolving it" (163). The success of Tolkien's fiction may be precisely in the distancing of his fantasy from Christianity. One of the most influential teachers in the present evangelical Christian community, Dr Timothy Keller, reflects on the reasons for its narrative potency in "The Lord of the Rings and Redemptive Art" (2010): he commends Tolkien's "highly nuanced" portrayal of the good versus evil story, and attributes this nuance to "neither a relativistic modern view of evil [...] nor a traditional dualistic view of evil" (2). Instead, Keller writes, Middle-earth is a world "filled with redeemed and redeemable persons"; and "the 'quest' in LOTR is really an 'anti-quest'" because it "is not a quest to find something but to lose something" - in this way, it performs salvation through "suffering and weakness and the giving up of all power", resulting in "a very Christian, non-sentimental kind of hope" (2).

By contrast, much of the criticism on Lewis appears to have his theology fixed in its sights. Lewis's ongoing influence among American evangelicals has often been dubbed as akin to that of a "patron saint" (McGrath 371), or a "theological and spiritual mentor" (369). Indeed, McGrath cites an article from a 1988 copy of Christianity Today which calls Lewis "the Aquinas, the Augustine, and the Aesop of contemporary evangelicalism" (374). Other works in the same 
camp include C. S. Lewis: A Guide to his Theology (2007) by David G. Clark and Marie A. Conn's C. S. Lewis and Human Suffering: Light Among the Shadows (2008). Even the study of humour in Lewis's works by Terry Lindvall, entitled Surprised by Laughter: The Comic World of C. S. Lewis (2012), describes Lewis's joy as an off-shoot of joyful theology - Joy being a term Lewis used in his own autobiography, Surprised by Joy (1955), for the conviction of faith in Christianity. Michael Ward's Planet Narnia: The Seven Heavens in the Imagination of C. S. Lewis (2008) is a unique study in that it does not based purely on either biographical or theological details of the author's life. Ward looks at the structuring of the Narnian chronicles according to medieval cosmology where every planetary deity is defined by several key attributes. In this book, Ward suggests that Lewis's conceptualisation of the Narnian chronicles was sufficiently influenced so that each of the chronicles was emblematic of one of the seven deities. It is another example of Lewis's confident pastiching of all kinds of mythologies into his own unique synthesis. While Ward's study is an example of a scholarly, though highly specialised, analysis, Ward states himself that as recently as 2008 Lewis's critics have commonly missed the mark, writing: "I am aware, of course, that Lewis had a low view of literary critics who attempted to discover inner meanings in his works; but I think his view of them was low because they missed their target, not because there was no target to aim for" (7).

What appears evident is that a common complaint brought by Lewis's critics is an argument concerning his worldview - such as that given by Haldane ${ }^{29}$ - wherein the literary critique can be fixed on theological difference to the exclusion of comment on fantastic creation. In her article "Paradise Lost and Found: Obedience, Disobedience, and Storytelling in C. S. Lewis and Philip Pullman" (2001), Naomi Wood describes the "traditionally didactic" arc of children's fiction (237) but takes issue with Lewis's own contribution to it in his Narnia series, where "[t]hose who disobey not only get punished, but idiotically frustrate themselves" (241). Penelope Lively, too, in her article "The Wrath of God: An Opinion of the 'Narnia' Books" (1968), uses descriptions like "savagery", "sinister", "merely absurd" (129), to describe what she sees as Lewis's "cardinal error of condescension towards children" (127). His books had a 'moral' she found "distasteful and alarming" (127). In The Magician's Book: A Skeptic's Adventures in Narnia, Laura Miller sums up in emotive terms a view that is still widespread, and I myself have encountered on multiple occasions when discussing this research:

If the Chronicles [of Narnia] were not going to save Christianity for me, Lewis's duplicity (as I saw it) was certainly capable of contaminating Narnia. He had hoped that his child readers, as they got older, would eventually come to see Narnia as filled with Christian meaning; perhaps he even hoped that

${ }^{29}$ Although Haldane did question Lewis's ill-defined science in his science fiction Space Trilogy, Lewis refuted it in a posthumously published reply, reminding Haldane that he was a storyteller, not a scientist. 
Christianity might be enriched by Narnia's magic [...]. But for me, Christianity worked like a black hole, sucking all the beauty and wonder out of Narnia the moment the two came into imaginative contact. I was furious, but I also felt bereft; I'd lost something infinitely precious to me. (101)

For Miller, and for many others, Lewis's theological framework and ideology smacks of religious propaganda, and seems somewhat pernicious for having been disguised as a children's book. In Miller's later records of conversations with others, "betrayed" turns out to be not uncommon amongst the words used to describe this effect (103). Spufford describes some people's feeling of being "got at by the Narnia books" (100). Neil Gaiman wrote a short story "The Problem of Susan", in which he directly addresses Lewis's eschatology and the apparent exclusion of Susan Pevensie from paradise, calling Susan's fate "intensely problematic and deeply irritating" (8)..$^{30}$ Yet despite those who dislike Lewis "do[ing] so very thoroughly" (C. S. Lewis: A Biography 255), the fact remains that "vast numbers of children read the stories with delight and live imaginatively in Narnia" (255), as writers such as Spufford testify. Alister McGrath has observed that Lewis is likely to continue as a divisive figure, accused "of writing disguised religious propaganda, crudely and cruelly dressed up as literature" while others "will see him as a superb, even visionary, advocate and defender of the rationality of faith" (378). Indeed, quite without religious affiliation with Lewis's position, Spufford writes that Lewis "had anticipated what would delight me with an almost unearthly intimacy. Immediately I discovered them, they became the inevitable expressions of my longing" (87). Wilson praises Lewis's "greatest quality [...] readability, the simple ability to write prose in such a manner that one wants to keep on turning the pages" (loc. 944). Nevertheless, as the world moves further away from that of Lewis's, Adey predicts that the readership of the Narnia books would live on mostly among "children of church-going but also of environmentally conscious parents" (278). Writing on Lewis's literary legacy, McGrath dwells on Philip Pullman's paradoxical affirmation of Lewis's cultural significance, in the very act of writing "a kind of 'anti-Narnia"' (377). ${ }^{31}$ Indeed, Pullman explicitly positions himself in opposition to Lewis's work. McGrath cites an interview in which Pullman professed himself so affronted by Lewis that he spoke of "dig[ging] [Lewis] up and throwing stones at him" (376) - even though Pullman's own fiction was a kind of "inverted homage" to Lewis. After all, Pullman does for secular humanism what Lewis did for Christianity (378).

\footnotetext{
${ }^{30}$ For those whose concern (or indignation) at Susan's fate persists after she is seemingly excluded from Narnia, I include a mention from Lewis himself in a letter to a child called Martin: "there is plenty of time for her [Susan] to mend, and perhaps she will get to Aslan's country in the end-in her own way" (Collected Letters: Volume III 826).

31 McGrath refers to Pullman's fantasy novels, particularly the His Dark Materials trilogy, comprised of Northern Lights (1995), The Subtle Knife (1997), and The Amber Spyglass (2000).
} 
In short, my stance is reminiscent of Adey's injunction that " $t]$ he only issue that should concern a critic is the quality of craftsmanship evident in the resultant works" rather than "the now dated game of psychoanalytical reductionism" (193), and perhaps I may add theological reductionism. I do not mean to imply that any of the numerous biographies which provide biographical and historical context to the writings are examples of such "reductionism". ${ }^{32}$ It is, however, possible that when there is such a wealth of material available which undertakes to make those connections, an approach which deals mainly with the substance of the craftsmanship, from a point of view that is neither singularly literary or theological focus but which attempts to blend them, is a useful addition to the existing scholarship. Wilson notes that Lewis felt that approaches to literature which suggest "we can only fully understand" a literary work "when we understand the man who wrote it" were a "personal heresy" (loc. 2684). Apart from humorously indicting his own work in this moment, Wilson sheds light on the evidence, his own work included, that such work has been done on Lewis before; done thoroughly and done well. If “the corollary of [Lewis's] great 'mythopoeia' discussion with Dyson and Tolkien was that the story of Christ was much more important than any doctrine which a fallible or fallen human mind could extract from it" (loc. 3912), then an approach which understands Lewis's conviction that story was more important than doctrine is valuable. What Wilson unwittingly proposes, whilst discussing the merits of Lewis's Space Trilogy, is room for a critique which focuses on "precisely [the] blend of literary originality and religious truth", and which acknowledges the literature of Lewis (and by extension Tolkien), "is not 'theology' dressed up as 'literature'; [but] rather it makes its best literary effects when it is at its most religious because the religious matter is what most engages the author's imagination" (loc. 2846).

\section{Conclusion}

As we have seen Tolkien's work has been held up as an exemplar of unreligious fiction, whereas Lewis's fantasy has been seen as religious propaganda. Both, however, employ the same technique: defamiliarisation. This thesis is concerned with the writing techniques of Tolkien and Lewis, addressing the actual works of fantasy which they had intended to write. I do not intend to engage too much with the reasons for both writers' popular success and their reader response, any more than to acknowledge that persistent popularity across multiple generations at least warrants serious consideration of the literature as literature. Of course, theology and fantasy are inextricably intertwined in their fiction; however, there is much still to

\footnotetext{
${ }^{32}$ Some excellent examples include: Roger Lancelyn Green and Walter Hooper, C. S. Lewis: A Biography (1974); McGrath, C. S. Lewis, A Life: Eccentric Genius, Reluctant Prophet (2013); and A. N. Wilson, C. S. Lewis: A Biography (2005).
} 
be said on the subject of the methods and techniques of both writers' literary invention, to see how their approaches encompass sophisticated theology and literary creation, with a view to mutually enriching both disciplines.

An anonymously pencilled comment, found at the end of Chapter 6 of my library copy of Shippey's The Road to Middle Earth, reads thus [sic]:

Just because JRRT was a Christian surely doesn't necessitate a Xian [Christian] exegesis. Great art works in any paradigm, and Shippey's constant efforts to tease out any Xian significance only alienates the pagan or atheist reader.

The annotator expresses a common suspicion that efforts to read or acknowledge the Christianity in fantasy is myopic or limiting, because great art must be great without reference to its worldview. As I see it, while great art is not specific to the culture in which (or of which) it was born, I do contend that there is value in considering the theology that informs these fantasies, the way in which the fiction of Tolkien and Lewis emerged from their ideological and theological paradigms - components of what Tolkien termed the 'leaf-mould' of the mind:

One writes such a story not out of the leaves of trees still to be observed, nor by means of botany and soil-science; but it grows like a seed in the dark out of the leaf-mould of the mind: out of all that has been seen or thought or read, that has long ago been forgotten, descending into the deeps. No doubt there is much selection, as with a gardener: what one throws on one's personal compost heap. (as quoted by Carpenter, J. R. R. Tolkien 126)

As both men were known amongst their peers for the sincerity of their faith, it would be remiss of any researcher to disregard such a prominent ingredient to their respective 'compost heaps'. The definite fork in research interests, and one I hope to bridge in this research, is that of the balance between the 'pure story' evaluation of fantasy, and that of 'pure theology.' Are they mutually exclusive concepts, and if so, where does one become the other? What is the role of the mediating author in all this, who must walk the line between literature functioning both as theology and as literature? These are the questions I mean to undertake in this thesis. Where commentators on Lewis (and Tolkien, but to a lesser extent) have erred is not so much in isolating his theology with too little focus on literary expression of it. In what follows, I hope, as Tolkien urged, to "be satisfied with the soup that is set before us, and not desire to see the bones of the ox out of which it has been boiled" ("On Fairy-Stories" 23). I mean to return to the literature and examine why, to extend the soup metaphor, such ingredients were chosen to be included in the story soup at all, and what they contribute to the flavour of the whole. 


\section{Methodological Introduction: Losing That We May Find}

Given the spirit of de-mythologising and increasing secularism in the era within which J. R. R. Tolkien and C. S. Lewis were writing, a very specific kind of approach to fiction was necessary to satisfy their appetites for both a sense of the holy in everyday life, and what they considered to be proper handling of fairy tale and myth. This approach may be summed up as their use of the technique of defamiliarisation. Defamiliarisation is a technique used to immerse the reader in material that leads him or her away from preconceived ideas. Although Viktor Shklovsky in his 1917 essay "Art as Technique” coined the term 'defamiliarisation,' the practice of defamiliarisation has a much longer history, and the term has been extended to apply to the work of Christian fantasists by Alison Milbank in her 2009 Chesterton and Tolkien as Theologians: The Fantasy of the Real. I extend Shklovsky's conception of defamiliarisation to include the techniques Tolkien and Lewis employ. What Shklovsky had in mind were poetic devices in realist fiction (in order to lend reality a certain charm and newness), while Tolkien and Lewis intended to "[give] it [the actual world] a new dimension of depth. [The reader] does not despise real woods because he has read of enchanted woods: the reading makes all real woods a little enchanted" ("On Three Ways of Writing for Children" 65). Defamiliarisation encourages us, as Milbank puts it, to "lose our apprehension of the phenomenal world in order to find it again: as itself, as something coming to us which is a mystery in its quiddity, its individuality and its difference from ourselves" (37). Defamiliarisation takes various forms linguistic imagery and (extended) metaphor, political satire, and invented other worlds. The emphasis on the aesthetic privileged immersive experiential story (rather than didactic 'allegory'), and at that point the act of creating art, especially story, had theological implications for Tolkien and Lewis. Seeking to tell grand mythological fantasy, Tolkien and Lewis used defamiliarising techniques to force their readers to approach the story as story first. They thus meant to demonstrate the full potential of story, to express and mask doctrinal material that was itself somewhat familiar. Beginning with Shklovsky and building on the foundation provided by Milbank, I intend to offer a detailed account of defamiliarisation as it is used in the fictions and other writings of Tolkien and Lewis. 


\section{Literary Defamiliarisation}

Although Tolkien and Lewis did not define their working method as 'defamiliarisation,' it is apparent that their methods and objectives were defamiliarising methods and techniques. While the principle has been applied by poets throughout the history of poetry, ${ }^{33}$ the critical term in literature owes its name (as we have seen) to Russian formalist Viktor Shklovsky in his 1917 essay “Art as Technique" (also rendered as "Art as Device” by some translators). The Russian formalists were particularly concerned with the importance of art and the role and function of literary techniques. In Shklovsky's view, defamiliarisation begins with the need to prolong the reader's experience of, and engagement with, the aesthetic. He believes that the act of perceiving is key to artistic engagement and impact. He writes that "the artistic quality of something, its relationship to poetry, is a result of our mode of perception" (2). Therefore, one should write in "a way [that] intensif[ies] the impressions of the senses" (3). For Shklovsky, 'perceiving' is this intensifying of the impressions of the senses, and is our mode of engagement with art. Perception, however, is too easily superseded by 'recognition,' that is, when objects are 'grasped' too quickly, too automatically. "We do not see them," Shklovsky says, "we merely recognize them by their primary characteristics" (5). In this way, the object itself fades under the influence of generalised, or what he calls "automatized perception" (6). Both the object and the act of perception are in danger of being or becoming automatic. Consequently, Shklovsky wishes to refresh perception. He believes that if unfamiliar language blocked or delayed access to what might easily identify the object being described, such a device could cause us to experience and not simply recognise that object. He writes:

The image [imagery] is not a constant subject for changing predicates [objects]. The purpose of the image is not to draw our understanding closer to that which this image stands for, but rather to allow us to perceive the object in a special way, in short, to lead us to a 'vision' of this object rather than mere 'recognition'. (10)

In other words, Shklovsky does not suggest a type of art which sought to draw attention to itself - to its own artistry or imagery as it were. Rather the imagery should be used to draw attention to and refresh the perception of the object it describes. Defamiliarisation might therefore be categorised as a means to re-invigorate one's perception of what might be too familiar to have any impact. As explained in the Routledge Encyclopedia of Narrative Theory (2005), defamiliarising functions "not in representing content and transmitting messages but rather in defamiliarising both its subject matter and the devices with which that subject matter is presented" (Schmid). Put more simply, Shklovsky's defamiliarisation entails "the transfer of an

${ }^{33}$ According to Shklovsky, this linguistic device is specifically linked to poetry and "poetic language" as far back as Aristotle (12). 
object from its customary sphere of perception to a new one" (Shklovsky 12). Essentially, defamiliarisation makes un-familiar by removing anything which might make familiar. The mode of perception is changed in order to force aesthetic engagement.

In one instance, Shklovsky gives an example of defamiliarisation from Leo Tolstoy's War and Peace (1869), when Tolstoy describes Natasha's first experience of an opera. Natasha's experience brings the reader back to what she is really seeing. Tolstoy's choice of language undermines the spectacle, reducing it by foregrounding the pasteboard props and painted theatrics. His way of moving things "out of their usual context" (Shklovsky 9), causes the reader to wonder at the fresh perspective - in this case, that theatre is after all an elaborate pageant. Nevertheless, the reader appreciates and wonders that the pageant could work so powerfully on (the rest of) its audience. A similar defamiliarisation renders the act of reading as "just looking at a dead piece of wood and hallucinating," as HuffPost rather whimsically reported in 2018 (Moran). Put another way, the effect of all this making strange is both to disabuse the reader of commonly held illusions, and to cause the reader to wonder anew. Defamiliarisation is in effect a "principle of 'difficulty"' (Shklovsky 13), so that art must have "the character of something foreign, something outlandish" (12). The device of defamiliarising immerses the reader in the immediacy of the experience or the unfamiliar perspective invoked by the unusual descriptive language. ${ }^{34}$

Another example is recorded by Oliver Sacks in his book The Man Who Mistook His Wife for a Hat (1985). The description is of an object "about six inches in length, [...] A convoluted red form with a linear green attachment" (Sacks 13). Although this example was given by a man with a neurological condition (who could not make the connection between the red rose he saw and its name), the example accurately describes Shklovsky's principle. In these words - a sixinch convoluted red form with linear green attachment - the customary sphere of perception is lost, even for the reader, by this strange description. The unfamiliarity of the description forces upon the reader something of the defamiliarisation this patient experienced. The reader is

\footnotetext{
${ }^{34}$ At this juncture, it is necessary to clarify an apparent overlap of terms between Shklovsky's estrangement and Bertolt Brecht's theory on the alienation effect or Verfremdungs-effekt (also named estrangement, or the distancing effect). An unfortunate typological error has rendered both terms "estrangement," as pointed out in Alexandra Berlina's introduction to "Art as Device". While the Verfremdungs-effekt does bear some resemblance to defamiliarisation, the concepts are quite different. While Shklovsky's theories laid the groundwork for Brecht, Brecht's interest in alienation ideology is to alert his audience to the ideological implications of his dramas, whereas Shklovsky desires to prolong the experience of the creative construction. Shklovsky's defamiliarisation enacts a cognitive separation of the familiar, not to political effect but aesthetic; it is a deliberate otherness to bring about fresh perspective (see Stanley Mitchell's 1974 article "From Shklovsky to Brecht: Some Preliminary Remarks Towards a History of Politicisation of Russian Formalism"). In other words, while Shklovsky is concerned to deflect conditioned responses as Brecht is, his reason is very different; the purpose of defamiliarisation is to restore wonder. Thus, it might be said that Shklovsky was motivated by an artistic purist's dissatisfaction with cliché.
} 
forced to consider anew, and very visually in this case, the shape, colour and indeed 'rose-ness' of a red rose- and not immediately or thoughtlessly to accept the familiarity of the designation, as they would had the word 'rose' simply been used in the first place. The potential to "[intensify] the impression of the senses" (Shklovsky 3 ) is lost when the object is automatically grasped, such as by naming it and bypassing the sensory experience, the wonder, of a strange description. This is the work of defamiliarisation: it eschews presuppositions and assumptions, and brings fresh sight, as if for the first time. Consequently, if familiar language, even naming objects, prohibits experience of the artistry, Shklovsky's 'principle of difficulty' aims to emphasise the aesthetic by circumventing automatic reception in favour of a more experiential perception.

\section{History and Uses of Defamiliarisation}

Although in his discussion of War and Peace, Shklovsky confines himself to Tolstoy's use of descriptive language, making strange is a broader technique. While Shklovsky was not necessarily the inventor or discoverer of defamiliarisation, he was one of the first to understand and articulate defamiliarisation as a vehicle for experience rather than recognition. For even though he published his essay in 1917, it was not translated into English until 1965, and so Shklovsky's particular influence on English literature could not have been widely known before then, except to readers of Russian. Defamiliarising has a long history of unique descriptors and unusual points of view in literature (though it is present in other art forms), and it can be seen operating through all facets of storytelling, not just in descriptive language. Jonathan Swift's 1726 novel Gulliver's Travels, for example, defamiliarises the political differences of the Whigs and Tories into Lilliputians and Blefuscudians. What makes Swift's novel so compelling is that while satirising the internal politics of the time, Swift nevertheless created a whole imaginary world. Fictive defamiliarisation can exist on a spectrum ranging from the merely linguistic (defamiliarisation in language and description), to the metaphorical (extended or otherwise), symbolic, allegorical, and even into the entirely strange alternative worlds of dreams (as in Lewis Carroll's 1865 Alice's Adventures in Wonderland), fantasy, and science fiction. The term has taken on something of a life of its own and has been applied to a range of very different types of writing 35 - all instances of which are designed to compel attention, in accordance with Shklovsky's sense of the poet's purpose.

\footnotetext{
${ }^{35}$ Shklovsky identifies instances of defamiliarisation in poetry, prose, and even erotic euphemism and riddle (10). Other writers have linked it to fantasy and science fiction (cf. Simon Spiegel's "Things Made Strange: On the Concept of 'Estrangement' in Science Fiction Theory").
} 
The history of fantasy literature, in particular, is rife with examples of defamiliarisation as an agent of world building: strangeness that is not necessarily odd, but rather other. There are many examples of defamiliarising fantasy: the legends of Arthur, Homer's Odyssey, the folktales of the Grimm brothers and Perrault, and various other stories taking place on other planets, dystopic worlds, and in wizarding schools. Fantasy is filled with that which, though never entirely strange, is still an othered version of the familiar. Removed from its customary sphere of perception, the familiar takes on unfamiliar qualities, or is removed to an unfamiliar location or context. Something similar happens to G. K. Chesterton's English explorer in Orthodoxy (1908), who "discovered England under the impression that it was a new island in the South Seas" (13). He "landed (armed to the teeth and talking by signs) to plant the British flag on that barbaric temple which turned out to be the Pavilion at Brighton" (13). The idea of a spiritual voyage, such as is found in Lewis's The Voyage of the Dawn Treader perhaps owes something to this Chestertonian tale (see Green and Hooper, C. S. Lewis: A Biography 127). The familiar, by thus becoming strange for a time, is restored to us in its brilliant potency - no longer something which our familiarity has rendered contemptible, as the saying goes. Somehow that familiarity in a new setting causes the familiar to be seen in a completely different way - such as might be the case with coming across a London lamppost in the clearing of an enchanted wood, or the comfort of the familiar Brighton pavilion when one was expecting an exotic temple.

Because fantasy is estranged from the normal, it is fertile landscape for defamiliarisation - even when, at the time Tolkien and Lewis were writing, many fantasy texts were thought to be children's fare. The entry on 'Children's Fantasy' in The Encyclopedia of Fantasy notes there is little recorded history of the development and audience of folktales, and it is difficult to know the impact folktales would have had on the idea of a genre for children (Clute and Grant 184). Children's fiction was certainly influenced by the popularisation of fairy tales, of Perrault and similar, in the 1700s, though a separate genre for children did not come about until later (184). Legends, romances, and sagas, such as the Arthurian stories in England, were part of the heroic genre which gradually became acceptable for children. In other words, works featuring action above all tended to move into the space marked for children, who were considered unable to identify with the reflective narrators, and heroes/heroines of novels. That is, as the realist and reflective novel became staples for adults, fantastic and action-centred stories were adapted and created for children. The mid-18 ${ }^{\text {th }}$ century saw the first children's adaptations of Gulliver's Travels and Robinson Crusoe, novels in which the action was exterior, as opposed to the increasingly popular novel form for adults, which represented the interior state of the protagonist. Such novels for adults were fixedly realist in mimetic depictions of life in the 
world, ${ }^{36}$ often masquerading as diaries or letters. Fantasy was therefore often relegated to the nursery. According to The Encyclopedia of Fantasy (1997), the fantasy genre for children owes its emergence to various genres of storytelling which were never originally engendered with children specifically in mind. The Encyclopedia names several influential books which began the process, but it cites Charles Kingsley's The Water-Babies (1863) and Lewis Carroll's Alice's Adventures in Wonderland (1865) as part of the critical transition point in the creation of a fantasy literature specifically for children:

The first [The Water-Babies] highlighted the transition: it called itself a fairytale and was intensely moralistic, but also portrayed children in a "real" world, and recognized their problems. Carroll's Alice stories flouted all past tradition and presented clever satires dressed up as nonsense in exactly the form that appealed to children. These two authors changed the world of children's literature and allowed the growth of CF [children's fantasy]. (185)

Even though children's fantasy was being written, such as by George MacDonald around 1870, the label of fantasy or fairy tale was one even children's authors fought against (185). Although fantasy was not necessary for children's literature in general, there is nevertheless something so intensely imaginative about certain children's books that, as The Secret Garden proves, for example, even "devoid of overt supernatural trappings", they are often still considered as fantasy (185). The works of E. Nesbit, Frank L. Baum, J. M. Barrie, and Rudyard Kipling, and others, each in their way, furthered sub-genres of children's fantasy with animated toys, beast fables, visits to magical places, worlds in miniature, secret gardens, time fantasies, other-worlds, and wish fulfilment finding a place in both literature and cinema for children. Animated films particularly form a substantial part of children's fantasy's overall presence (185-189). Whether fantasy or not, the 'magical' quality of these children's genres - even those 'devoid of overt supernatural trappings' - may be said to have something more to do with the ability, commonly ascribed to childhood, to 'see strangely' than with strangeness at all. As Shklovsky declares, "enstrangement can be found almost anywhere" (9). The goal of defamiliarisation in art is the recovery of wonder - whether it be in the fantastic or the realist mode - and wonder, culturally is the province of childhood.

Tolkien and Lewis have both explicitly admired a principle of strangeness - not only for writing fantasy but also for the entirety of creative endeavour. In the first place, something very like defamiliarisation (though not so named) has been suggested by both Tolkien and Lewis in

\footnotetext{
${ }^{36}$ One might make the argument that all fiction, even realist, is a defamiliarisation of reality to some extent. Rosemary Jackson has furthermore noted that "[a]s a literature of 'unreality', fantasy has altered in character over the years in accordance with changing notions of what exactly constitutes 'reality'" (R. Jackson 4).
} 
various of their creative manifestos, ${ }^{37}$ foregrounding strangeness rather than over-familiarity or presupposition. For Tolkien, creative writing ${ }^{38}$ requires "a quality of strangeness and wonder in the Expression" ("On Fairy-Stories"44), an artistic vision "freed from the drab blur of triteness or familiarity - of possessiveness" (52), and the introduction of things that "are indeed not to be found in our primary world at all" (44). Even if the writing is fantastic, he says, it is capable of imbuing the familiar world with new wonder, freed from our possession of it (that possession seems to be equivalent to automised perception). Fantastic writing has a quality of "arresting strangeness" (44). Tolkien calls this process Recovery:

But the true road of escape from such weariness [familiarity] is not to be found in the wilfully awkward, clumsy, or misshapen, not in making all things dark or unremittingly violent; nor in the mixing of colours on though [sic; i.e., through] subtlety to drabness, and the fantastical complication of shapes to the point of silliness and on towards delirium. Before we reach such states we need recovery. We should look at green again, and be startled anew (but not blinded) by blue and yellow and red. [...] This recovery fairy-stories help us to make. In that sense only a taste for them may make us, or keep us, childish. Recovery (which includes return and renewal of health) is a re-gaining-regaining of a clear view. (51-52)

Just as Shklovsky proposed, so does Tolkien now: the process of estranging brings the familiar back into view as something new and worthy of wonder. Tolkien suggests that this regaining of clear sight, however, is only the result of an 'arresting strangeness'. Similarly, Lewis wrote in his essay “On Three Ways of Writing for Children” (1952):

fairy land [that is, fantasy or strangeness] arouses a longing for [the child] knows not what. It stirs and troubles him (to his life-long enrichment) with the dim sense of something beyond his reach and, far from dulling or emptying the actual world, gives it a new dimension of depth. He does not despise real woods because he has read of enchanted woods: the reading makes all real woods a little enchanted. (65)

Lewis's analogy of real and enchanted woods suggests that while the realm of fairy can be appreciated for its strangeness, it throws back a light on the familiar, investing the familiar with a kind of enriched meaning. Lewis echoes Shklovsky's sentiments when he furthermore suggests that the lens of seeing strangely can be applied almost anywhere. Lewis writes in his essay "On Stories", that "[n]o man would find an abiding strangeness on the Moon unless he were the sort of man who could find it in his own back garden" (36). The reason defamiliarisation is such an appropriate paradigm for analysis of Tolkienian and Lewisian texts is because it is (though they did not use the term) fundamental to their fiction.

${ }^{37}$ Such as Tolkien's Andrew Lang lecture in 1939, "On Fairy-Tales", and various of Lewis's essays, many of which can be found in his collection Of This and Other Worlds (namely "On Stories", "Sometimes Fairy Stories May Say Best What's to be Said", and "On Three Ways of Writing for Children"). 38 Or sub-creation, Tolkien's theory of creativity - a theory more fully discussed in my following chapter. 
To employ this defamiliarising lens to analysis of their work would therefore be to undertake exactly the approach to literature that both Tolkien and Lewis espoused. Though their fictions were steeped in Christian theology and Northern folk and fairy tale, the fantasy writing of Tolkien and Lewis defamiliarised these influences and concerns. This was partially in order to create original worlds, and partially (even sub-consciously perhaps on Tolkien's part) to restore wonder in the Christian doctrine, to make it numinous to the cultural mind once more. Both authors strove to invoke wonder both towards their created worlds and towards the Christian ideas they illuminated, freeing up the reader to experience them as if for the first time. Tolkien and Lewis saw that the familiar stories from the Biblical tradition were beyond the reach of that unassuming first reading. We may not be able to read something 'for the first time' twice, yet this is exactly what Tolkien and Lewis were attempting to make possible. Lewis specifically expressed it as writing without the "obligation to feel [that] can freeze feelings" ("Sometimes Fairy Stories" 73). As a result, Tolkien and Lewis strove to separate their fictional worlds as much as possible from their Biblical source material. They were not satisfied to rewrite what had gone before, even though they were drawing from what would be somewhat familiar stories for many; working within the framework of that familiarity was what gave defamiliarising creativity its opportunity. ${ }^{39}$ As Lewis wrote in his essay "Sometimes Fairy Stories", if the mythic mode

is well used by the author and meets the right reader, it has the [...] power: to generalise while remaining concrete, to present in palpable form not concepts or even experiences but whole classes of experience, and to throw off irrelevancies. But at its best it can do more; it can give us experiences we have never had and thus, instead of 'commenting', can add to it. (74)

This idea of adding to life is what Tolkien would call "the effoliation and multiple enrichment of creation" ("Of Fairy Stories" 63).40 From this conviction I draw my central argument, according to what Shklovsky originally outlined as the goal of defamiliarisation: that recreating or evoking the first experience of narrative is exactly what Tolkien and Lewis aimed at in their defamiliarisation of Christian narrative. And this new re-iteration is a kind of study or exploration of the same territory, seeing it with new eyes, learning and exploring its ways and limitations with a fresh perspective.

\footnotetext{
39 Indeed, one 2011 study, "Story Spoilers Don't Spoil Stories” by Jonathan D. Leavitt and Nicholas J. S. Christenfeld, shows that some foreknowledge of story does not necessary spoil the story, and may even "enhance" it (1153). Their study demonstrates the complex relationship between a reader and a text and 'spoilers' - that is, giving away the ending, or at least a major plot point or organising principle in a story, affirming that even if the story is not experienced as entirely new, the writing may still score highly in the researchers' categories of enjoyment, appreciation, and transportation.

40 See Campbell, Richard Brett. "Assisting the Effoliation of Creation: JRR Tolkien's Sub-Creation Theory and CS Lewis's Imagination”. Union Institute and University, 2010.
} 


\section{Theological and Fantastic Defamiliarisation}

This brings me to the uses of defamiliarisation in theological, particularly fantasy, writing. Milbank has expanded Shklovsky's definition, drawing on his work to illuminate the theological thinking in the fantasy works of Chesterton and Tolkien. Although her book is situated more within the theological and philosophical tradition, it has laid the groundwork for my analysis of the intersection of defamiliarisation and theology in literary fantasy. Milbank's account of defamiliarisation does not limit it to a linguistic device, to expand on earlier discussion, but it becomes more

a device to sunder our lazy ownership of perception, so that we lose our apprehension of the phenomenal world in order to find it again: as itself, as something coming to us which is a mystery in its quiddity, its individuality and its difference from ourselves. (37)

Defamiliarisation for Milbank is not just making strange, but refreshing perception entirely, to appreciate not only that which it defamiliarises, but also something new. ${ }^{41}$ Drawing heavily on orthodox theologians, including Augustine and Aquinas, Milbank's work proposes new ways in which 'making strange' is achieved, expanding it specifically to analyse fantasy fiction written by Christian authors. She divides the principle of making strange into two camps: Poetics (that is, defamiliarisation in the act of creating fiction) and Praxis (which is defamiliarisation manifested in the world of interaction of the characters and readers). In terms of Poetics, she categorises defamiliarisation as fantastic modes, grotesque forms, and the use of paradox or riddles. First, Milbank describes defamiliarisation as foregrounding strangeness in fiction. Often, this is done by casting into the realm of fantasy. Second, like literary Quasimodos or Gollums, the grotesque presents the strangeness of corrupted form (which suggests by its very 'wrongness' an ideal to be aspired to). Because the corrupted form of the grotesque inversely suggests a form that is not corrupted, Milbank argues that it images the narrative of the Fall: for her, the grotesque simultaneously acknowledges both Creator and creation that has fallen from its original glorified state, and therefore yearns for redemption to perfection. Third, through paradox and riddle, Milbank suggests something of the way defamiliarisation invites, even presumes, collaboration with the reader, deliberately confusing easy understanding so that the reader is required to work to make sense of the text. In the Praxis category (less significant for the purposes of this study), defamiliarisation can be seen in the actions of fairy economics (that is,

${ }^{41}$ Tolkien has similarly referred to this effect as the 'Mooreeffoc' effect. He had taken this term from an anecdote told by G. K. Chesterton about Charles Dickens who saw a "fantastic word" one foggy London night - a word which turned out to be no more than 'coffee room' seen through the wrong side of a glass door. For Tolkien, the Mooreeffoc effect signified the "queerness of things that have become trite, when they are seen suddenly from a new angle" ("On Fairy-Stories" 52). 
the economy of gift-exchange), and of fairy poetics (that is, making believe, the construction of childhood, the child reader, and child psychology). Milbank was concerned with how Chesterton's exemplifying strangeness influenced Tolkien: in what follows, I apply her thinking to the influence of Tolkien and Lewis upon each other. Of particular interest to me in the fiction of Tolkien and Lewis are the typological representations of Creation and the Fall, archetypes of Adam and Christ, and resurrection and endings, as I shall explain in ensuing chapters.

The realm of the un-familiar or strange does not mean a complete separation from reality. Quite the contrary: defamiliarisation owes its entire effect to a reliance on what is familiar. Defamiliarisation represents the finding of "new ways to restore language as a signifying medium of the real world" which for Milbank is "namely the fantastic" (29). As Rosemary Jackson puts it in Fantasy: The Literature of Subversion (1981):

Fantasy is not to do with inventing another non-human world: it is not transcendental. It has to do with inverting elements of this world, recombining its constitutive features in new relations to produce something strange, unfamiliar and apparently 'new', absolutely 'other' and different. (8)

Although I cannot agree that fantasy is never transcendental, Jackson's point rings true: fantasy's deliberate distancing from reality might be regarded as providing a reaction to or commentary on that reality. The exploration of defamiliarised territory, whether in linguistic form or in the form of fantastic worlds, maintains some association or connection to the real. The estrangement from reality paradoxically informs its engagement with reality, even though it is a view of the world that is not photographic or straightforwardly representational. Milbank writes that defamiliarisation in the form of fantasy "is a mode of exploring the real through imagination" (146). For this reason, Milbank concludes that Chesterton and Tolkien were "writing fictions about real things" (xv), that is, they were engaging with larger issues of philosophy and theology. Similarly, Tolkien critic Patrick Curry observes that "two of the most important things about art, literary or otherwise [are]: that reality is (also) ineluctably fictional, and that fiction and its referents are (also) unavoidably real" ("The Critical Response to Tolkien's Fiction" 376). The relationship between defamiliarisation and theology is of the essence for my thesis, as it was for Milbank, because in a sense, central Christian beliefs might be said to be a defamiliarisation of the empirical world we experience. As Lewis has said, it is where myth and reality meet, myth that 'really happened'. Certain norms have already been overturned. Traditional Christianity believes, for example, in an external creating power without which the universe could not exist, the existence of an immortal soul, and therefore the possibility of life after death, the idea of a corporeal resurrection, the dual nature of Christ (human and divine), and a triune Godhead. Presented in this light, the beliefs of Christianity might be described as more unfamiliar than familiar. In Orthodoxy, for example, Chesterton 
likewise undertook to "set forth [his] faith as particularly answering [a] double spiritual need, the need for that mixture of the familiar and the unfamiliar" (14). Taken together, these ideas suggest defamiliarisation as a lens for regaining what Tolkien and Lewis thought to be at the heart of the Christian theological doctrine, namely the concept of an all-creating God, fallen nature, and redemption through his incarnation and resurrection. Though estranged, our view is enriched, and all the original impact of these Christian stories is restored, where before it appeared familiar and trite.

Lewis too felt that this kind of enchantment (what Shklovsky and Milbank might call estrangement), could serve to restore wonder to Biblical stories which had lost their potency through familiarity. After all, as Michael Nelson notes, for Lewis "the best vehicle for conveying mythic aspects of Christianity was fiction - science fiction and fantasy, in particular, because these 'could be combined with the supernatural appeal'" ("Lewis and His Critics" 10). Lewis's own conversion story reflects his distaste at the time for the gospel story, whereas a similar mythological story might powerfully move him. He wrote this to his friend Arthur Greeves in 1931:

if I met the idea of sacrifice in a Pagan story I didn't mind it at all: again, that if I met the idea of a god sacrificing himself to himself [...] I liked it very much and was mysteriously moved by it: again, that the idea of the dying and reviving god (Balder, Adonis, Bacchus) similarly moved me provided I met it anywhere except the Gospels. The reason was that in Pagan stories I was prepared to feel the myth as profound and suggestive of meanings beyond my grasp even tho' I could not say in cold prose 'what it meant'.

Now the story of Christ is simply a true myth: a myth working on us in the same way as the others, but with this tremendous difference that it really happened: and one must be content to accept it in the same way, remembering that it is God's myth where others are men's myths. (Collected Letters: Volume I 976-77)

The significance of this revelation is paramount in understanding the beliefs of both Tolkien and Lewis. It goes without saying that even as they wrote fantasy, and discussed its enriching effect on the familiar, they often intended fantasy to engage the imagination as it embodied the gospels. This 're-mythologising' was not merely restoration of the ordinary, but harkened back to 'True Myth'. Thus, Lewis proposed the recasting of the gospel story, in order to recover the potency of feeling that should be natural if religion did not seem to oblige certain emotional responses. In his essay “Sometimes Fairy Stories” (1956), Lewis muses:

I thought I saw how stories of this kind could steal past a certain inhibition which had paralysed so much of my own religion in childhood. Why did one find it so hard to feel about God or about the sufferings of Christ? I thought the chief reason was that one was told one ought to. An obligation to feel can freeze feelings. [...] But supposing that by casting all these things into an imaginary world, stripping them of their stained-glass and Sunday school 
associations, one could make them for the first time appear in their real potency? Could one not thus steal past those watchful dragons? I thought one could. (73)

Lewis speculates that the religious obligation to feel, or to respond, had robbed the gospel stories of their potency. ${ }^{42}$ To restore the potency of these stories required, in Shklovskian terms, the removal of an object from its customary sphere of perception to a new one. What Lewis suggests here serves the goal of defamiliarisation, if not quite the technique. He suggests the transmutation of subjects or forms that are prone to a predetermined reception, to a new form, in the realm of the imaginary or fantastic. In doing so, he is not suggesting something new, but following in the footsteps of such authors as G. K. Chesterton, George MacDonald, J. R. R. Tolkien, and authors like them. Lewis is unwittingly echoing Shklovsky (before him), Milbank (after him), and others by seeking to engage imagination through providing an unfamiliar form, a form devoid of these obstacles to aesthetic experience (in an artistic sense), and belief (in both the fantastic and religious sense). In a world of 'Sunday school' familiarity, he proposes the creation of a new space for imaginative exploration.

The employment of defamiliarisation in fiction is therefore essentially heuristic: it promotes learning through problem-solving and experimental discovery, requiring the reader's participation to make meaning. Paul Ricoeur writes in Oneself as Another (1996) that all fiction does this to some extent: "[l]iterature is a vast laboratory in which we experiment with estimations, evaluations, and judgements of approval and condemnation through which narrativity serves as a propaedeutic to ethics" (115). The effect of defamiliarisation in fiction proves to be exactly the condition for explorative, reflective reading. ${ }^{43}$ Similarly, Umberto Eco

\footnotetext{
${ }^{42}$ Interestingly, the fact that some readers feel betrayed to learn of the Christian undertones in Lewis's texts shows that in some respects he was right to think it possible to steal past watchful dragons - even temporarily. To Laura Miller, Narnia was a welcome antidote: "Narnia and Aslan made me happy. Jesus wanted me miserable. [...] Narnia was liberation and delight. Christianity was boredom, subjugation, and reproach. [...] For me, Narnia was Christianity's antidote" (The Magician's Book 96). Miller records, however, that she and others she interviewed felt betrayed to learn of the Christian undertones to Lewis's story. Lewis was therefore also wrong in that even the first 'real potency' of the story, or at least the methods he used, continue to repel some. Miller also speculates that had she found this out for herself, and not been told, she would likely have felt less angry about Lewis's techniques.

${ }^{43}$ In "Effects of Literature on Empathy and Self-Reflection" (2015), Eva Maria Koopman and Frank Hakemulder note that imaginative engagement with a text can stimulate self-reflection: "Fictionality might stimulate readers to consider the narrative they read as a thought experiment [...]. Literary features, like gaps and ambiguous characterization, may stimulate readers to make more mental inferences" (91-92). Of particular interest is their notion of fiction acting as a "moral laboratory" (92), as Ricoeur suggested. Koopman and Hakemulder speculate that defamiliarisation might provide the right environment: "[foregrounding] features in the text (e.g., novel metaphors, rhyme) can lead to aesthetic feelings of perceived beauty, but particularly surprise and defamiliarization" (100), which in turn "provoke[s] longer reading times and stronger effect" (99). The longer reading time is perhaps the key here. What interests me, however, is that the "striking features" (99), a text's gaps, ambiguities, and nuance, invoke a more engaged reading, just as Shklovsky theorised. Koopman and Hakemulder conclude that readers "become unsettled and start looking at familiar things in a different way (defamiliarization)" (99).
} 
writes in "The Theory of Signs and the Role of the Reader" (1981) that "a text is a lazy machinery which forces its possible readers to do a part of its textual work," and therefore that a text's modalities are "multiple, and possibly infinite" (36). Defamiliarisation's principle of difficulty, the device which forces the reader to engage with (and not merely pass over) the aesthetic, is also what invites and invokes the imaginative participation of the reader as an agent of making meaning. In a later essay, "Apologetics and the Imagination: Making Strange" (2011), Milbank argues that it is through the imagination that this experiential knowing is principally received and explored: it is understanding in a "participatory" way that "has implications for the whole way of experiencing reality [...] to give us access to the divine and to the reality and otherness of the world beyond the self" (32). In other words, the reader must employ his or her imagination to make sense of the imaginative creativity of the defamiliariser. It is not enough to know; art requires that we experience. The principle of deliberately obscuring compels something from the reader and invites them to explore the meaning because it is not readily available (through customary expression or environment). Accordingly, Milbank writes that " $[t]$ he work that the imagination performs in uniting the 'before' and 'after' of the defamiliarization effect has a creative dimension, akin to that of the artist himself" (37-38). This statement suggests that the creativity of the author more importantly invokes the creativity almost to the point of artistry - of the recipient or the reader. It is a process which is explorative and imaginative: the reader is active in the meaning making, participating on an artistic level as well to discover and create meaning.

Estranging storytelling modes have a particularly strong tradition in the defamiliarisation of theology - as has been demonstrated as early as Jesus's use of parables (a new teaching form that was both simple analogy and hermeneutic riddle), Biblical drama, and the varied use of allegorical representation throughout literature. Biblical drama has the interesting dimension of defamiliarising by localising Biblical stories in their own time and landscape, effectively making them more familiar and recognisable. In his book Fool's Talk: Recovering the Art of Christian Persuasion (2015), Os Guinness points out:

For the early Christian apologists in the time of the Roman Empire, the challenge was to introduce a message so novel that it was strange to its first hearers, and then set out what the message meant for the classical age and its sophisticated and assured ways of thinking. For much of the advanced modern world today, in contrast, the challenge is to restate something so familiar that people know it so well that they do not know it, yet at the same time are convinced that they are tired of it. (28)

Likewise, defamiliarising fiction effects this explorative and restorative enrichment for theology. According to Milbank, although "imagination is [...] a tool for apologetics [...] the imagination is [also] a philosophical tool that helps us reason by providing an epistemology, a way of knowing, 
that is inherently religious" ("Apologetics and the Imagination: Making Strange" 31-32). In this sense, the imagination provides tools to grapple with ideas that are new, as well as with what is familiar. Imagination provides the reasoning skills to explore hypotheticals. Ralph C. Wood makes a similar point in the introduction to Literature and Theology (2008). He expounds a theory of Christian literature which endorses a kind of experiential exploration of fiction as the best way to understand it. He writes that the aim is "not to reduce these texts [...] but rather to enable readers to experience them both imaginatively and theologically" (Wood vii). Imagination is crucial for fantasy writing and is an essential tool for the grasping not only of theology but of the metaphysical world that we reside in. Theology begins, after all, in imagining a world beyond the self.

To engender this explorative defamiliarisation that is not curtailed by assumption or familiarity, Wood speculates similarly that such writing seeks not only to be evocative but to defy expectation. He writes that far from being "comforting or consoling", the writing's effect is "often disturbing" (Wood vii). These are interesting statements for two reasons. First, Wood agrees with the premise of defamiliarisation, that the experience must be fresh and new in order to allow for an imaginative - even spiritual - experience. Second, and in paradoxical contrast to the first point, the writing or experience is essentially a story retold. Wood observes that even the gospel story retold often "is not obvious but scandalous" (viii). The effect of the reimagined story must be therefore never obvious but rather unexpected, even disturbing, scandalous - at the very least unusual. ${ }^{44}$ We might safely assume then that defamiliarisation (theological or otherwise) also functions to disrupt expectations, to catch the reader 'off-guard', as it were.

\section{Defamiliarisation as Fantasy}

Having considered fiction as a form of making the real strange, and as a form of defamiliarising theology, it is appropriate now to turn to the idea of fantasy as a form of defamiliarisation which might feasibly deal with theology. As a mechanism in fantasy worldbuilding, defamiliarisation inevitably has a mythic dimension, in that the origins of that other world have somehow to be explained. Though they must follow some equivalent laws of nature or be internally consistent, world-building in fantasy cannot be taken for granted - whereas realist fiction must adhere to a certain predictability or mould of everyday life and its scope of possibility. Defamiliarisation of worlds in the form of fantasy takes Shklovsky's

\footnotetext{
${ }^{44}$ Even Tolkien's concept of the 'eucatastrophe' - a sudden and unexpected joyous turn for the better - is in some ways a subversion of expectation when the odds are against it.
} 
defamiliarisation technique (which he limited to descriptive language) to a completely new level. Hence, "fiction in the form of fantastic recreation of the world can give us access to the real by freeing the world of objects from our appropriation of them" (Milbank, Chesterton and Tolkien as Theologians 19). For Milbank, who views their fantasy as a legitimate communication of theology, Chesterton and Tolkien (and I would extend this to include Lewis too) use "fantasy and the fictive to restore our true relations with what Auden called 'those wordless creatures who are there as well'" (xv). Here, fantasy is an aid to the restoration of the real world, and to the human faculty of making meaning. Yet - importantly - this method is notably not used for proselytising. This is a point worth dwelling on. Defamiliarisation concerns itself with the manner of looking, as it were, rather than of convincing. "The task is not to 'sell' God as an object of credence," Milbank writes, "so much as to offer a whole way of regarding our experience and beginning to reintegrate our experience" ("Making Strange" 34). By removing our world and replacing it with fantasy, the authors position the reader within that framework as an explorer of the world and of meaning itself.

There is something further to be said about the role of children, and children's fiction, in theological defamiliarisation. As demonstrated by Jesus's principle of 'becoming as little children' and the kingdom of heaven belonging to 'such as these' (see Matthew 18:3 and 19:14, respectively, and 1 Corinthians 1:18-22 on Christian folly), there is a strong precedent for considering children as having easier and less filtered access to the wisdom of God. In The Well of Being: Childhood, Subjectivity, and Education (2006), David Kennedy writes that the archetypal Fool in literature and the child have something in common in that both

effect a reversal of an established patriarchal wisdom tradition. Both assert the claims of a form of knowledge that comes from the margins, and therefore is paradoxical, enigmatic, even garbled, and spoken in a 'prelapsarian tongue'. [...] The Fool and the child differ in that one is post-adult and one pre-adult, but both point to the same thing - a transgressive wisdom, the wisdom of the liminal and the marginalized, of reversal and play and subversion of conventional norms and understanding. (11)

Although Tolkien and Lewis both bristled at the implication of puerility when fantasy was dismissed as 'children's books', Kennedy asserts there is some 'transgressive' influence in that category - just as the Fool in King Lear was able to speak truth to power with impunity (even if his transgression was sanctioned by that authority). Kennedy also observes that Jesus associated with the least of society, and children were considered to be the very least, just as children's literature (especially fantasy literature) has long been thought to be a less sophisticated and lesser category of fiction. Children (and children's fiction) represent a kind of other knowledge, and there is potential in the liminal spaces of children's fantasy to address dominant structures of knowledge and power in much the same way that the Fool addresses the 
King. As Kennedy puts it "the child and the fool - both of whom subvert adult models of knowledge and conduct - become models of spiritual knowledge and development" (28). Os Guinness has similarly noted the subversive power of the Fool, and writes that:

[t] he fool maker is the person who (once again) is not a fool at all, but who is prepared to be seen and treated as a fool, so that from the position of derided folly, he or she may be able to bounce back and play the jester, addressing truth to power, pricking the balloons of the high and mighty, and telling the emperor that he has no clothes. (72)

There is therefore something to be said for the defamiliarisation of religious ideas in genres that are not traditionally thought of as sophisticated, or even popular, by the contemporary reading public. This is not to say that Tolkien and Lewis selected non-realist (or children's) modes especially for this purpose, but it is interesting to note their correlation with the model of Jesus's association with what society despised.

\section{Poetic and Conceptual Defamiliarisation}

A distinction can be made between aesthetic or poetic defamiliarisation and conceptual or doctrinal defamiliarisation. Tolkien and Lewis use both. The first kind is more closely associated with Shklovsky's poetic defamiliarisation, in its concern for the aesthetic appeal. This is the kind of defamiliarisation, for example, evident in the transformation of Biblical Israel into the enchanted fairy land of Narnia. Adult protagonists, such as the disciples and early church, are now children and animals. The unseen enemy, Satan, is made manifest in the figure of a wicked witch; the fruit of temptation becomes Turkish delight. The man Jesus is a lion. These differences are no mere swapping one type of thing for another; all are consistent with the reality of an entirely different world. They exist outside of analogical or symbolic forms, for each has its own history, magic, and species. These aesthetic choices are arresting; they make us pause, submit to their effect; they worry us, and - most of all - they make us notice. ${ }^{45}$

Conceptual defamiliarisation works in a different way, but to the same purpose. The authors may not be making strange by making entirely new, but they are deliberately redirecting the imagination from traditional visualisations of Biblical material, by colouring it with their own ideas and inviting the reader to do the same. Resurrection, for example, is represented as both akin to and different from the Biblical idea: it is children growing up in Narnia, and then returning to childhood through the wardrobe; it is Gandalf the Grey physically taking on the appearance of Saruman the White. The idea of resurrection after death is already

\footnotetext{
45 In Lewis's Narnian chronicles in particular, these choices were made deliberately to appeal to children, touching on the popularity of animal stories, and secret fairy lands.
} 
present in Christianity; when the authors employ this idea, they distance the readers from scientific/physical death, but not from the traditional Christian idea as they know it - an idea I shall return to in my fourth Chapter. Another example of altered visualisation of Biblical material is the Christian idea of Jesus as a returning king, not in Biblical garb defeating the Romans, but as Aragorn in a mythic kingdom, more of an itinerant knight helping others with their quests than a conquering king in his own right. It should not be forgotten that Jesus never appeared physically as a king in the gospels (although there was a significant expectation that a king would appear, and Jesus's version of kingship was a significant defamiliarisation of that idea - see John 18:36). In this context, even to have a Christ figure who is a king is defamiliarisation of a kind.

Lewis even suggests that what is considered to be normal is in fact stranger than we might perceive. In Perelandra, the second book of his Space Trilogy, the narrator visits Ransom on the eve of another journey into space, and muses that when

[t]he distinction between natural and supernatural broke down [...] one realised how great a comfort it had been - how it had eased the burden of intolerable strangeness which this universe imposes on us by dividing it and encouraging the mind never to think of both in the same context. (153)

Lewis is challenging the very notion of what is considered 'normal reality.' He suggests that even our conceptualisation of what is natural and what is not is flawed: mere familiarity with the universe is the only thing keeping us from being always in awe of it, from acknowledging its 'intolerable strangeness.' From there it is just a short step to poetic or aesthetic defamiliarisation: having accepted a Christian worldview (such as death not actually being death, for instance), it is not a stretch for the reader to accept its aesthetic representation (such as literalising resurrection). The fictional worlds of Tolkien and Lewis have a 'numinosity' which is part of their theological view of the real world. These figures are what Tolkien called "the effoliation and multiple enrichment of creation" ("On Fairy-Stories" 63); they are imaginative interpretations, designed to add to the imaginative possibilities evoked by the doctrine. The authors suggest one way to imagine it, and suggest that the reader is free to do the same.

\section{A Note on Allegory}

Both Tolkien and Lewis have been categorised as writers of allegory, and both have refuted that categorisation. While allegory can work to defamiliarising effect, I will argue that, ultimately, describing their work as simply allegorical does not go far enough, and can indeed misrepresent what these authors are doing with their world-building. 
The word allegory comes from the Greek 'a speaking otherwise' and has come to be understood as a symbolic narrative mode of layering meanings (Sandywell, "Dictionary of Visual Discourse" 135). According to the Dictionary of Biblical Tradition in English Literature, allegory may explore the relation between two objects, often through symbols, types, and antitypes, which are "the visibilia into which allegory pours its meaning" and which are "meaningful only in terms of something else, symbols to their referents, types to their antitypes" (29, emphasis added). Allegory derives its meaning, its completeness, therefore, from referring to something else - an abstract idea or another reality. Accordingly, the function of allegory is "exegetical" and didactic, a secondary source intended for the interpretation of the primary (Scripture) (30). One may deduce that allegory is used as an interpretative device: understanding it requires a kind of 'other knowing'. The Dictionary furthermore acknowledges the difference between allegorical interpretation and allegorical invention. Indeed, the Dictionary concludes that " $[\mathrm{g}]$ ood allegory is nuanced, some shades of meaning being discerned by readers rather than being obtruded on their sensibilities" (30).

As medievalist scholars, both Tolkien and Lewis would have been familiar with the concept and uses of allegory. An index of allegory in The J. R. R. Tolkien Companion and Guide provides evidence that Tolkien indeed understood and used allegory to some extent - Tom Bombadil, Tolkien once wrote, is in some way "an 'allegory', [in that he is] an exemplar, a particular embodying of pure (real) science" (Letters 192). Some critics have said that Leaf by Niggle and Smith of Wootton Major contain a kind of autobiographical allegory (40). Tolkien is also known to have appreciated the dragon imagery in Beowulf which was "balance[d] exactly between 'dragon-as-simple-beast' and 'dragon as just allegory' [for greed]" (217). But even as he used allegory, Tolkien gave fiction's surface value as much importance as its potential, suggestive, or symbolic value. In other words, his work cannot be thought of as 'only' or 'merely' allegory. Tolkien felt that the text was not simply a vehicle for imparting a meaning, but needed to simultaneously function as a creative product - as art for art's sake. Lewis in his turn wrote an academic work, The Allegory of Love, in which he described 'bellum intestinum', internal conflict, and conceded that "external conflict in a narrative may well represent spiritual warfare, conflict within" (31) - a defining feature many readers might find in a number of his fantasy works. It is not difficult to see why the writing of Tolkien and Lewis might attract allegorical reading. Lewis's own fictions, The Great Divorce (about a man who visits Heaven in a dream), and Screwtape Letters (with an actual devil from Hell) could be defined as a sort of allegory, though defamiliarised (as in Screwtape's epistolary found-manuscript format). To reduce their writing to just allegory, however, is to miss some of the larger aesthetic and defamiliarising writing choices being made. 
The not insignificant difference between allegory and defamiliarisation lies in this: where defamiliarisation seeks to delay the grasp of meaning, and inhibit instant understanding for maximum aesthetic engagement, allegory readily proposes interpretation (although it does not avoid ambiguity). As Lewis wrote in 1958,

"By an allegory I mean a composition (whether pictorial or literary) in wh. Immaterial realities are represented by feigned physical objects e.g. a pictured Cupid allegorically represents erotic love (which in reality is an experience, not an object occupying a given area of space) or, in Bunyan, a giant represents Despair. (Collected Letters 1004)

Bunyan's "Slough of Despond" in The Pilgrim's Progress, for example, deliberately connects an abstract state of mind (despondency) to the mires of a bog. While this allegorical connection considerably enriches the idea of the state of despondency with new associations and meaning, the concept is transparent: grasped immediately and without the need for imaginative working out. Much of the modern disdain for allegory, indeed, comes from the view that the 'message' or 'moral' is too obvious, not nuanced enough, and that it is thought to impose views upon the reader. Allegory's common characteristics - "its dualism of absolute good and absolute evil [...], its apparent determinisms, [...] its tendency to caricature" and its tendency to "[translate] abstractions into images instead of beginning with images" (Dictionary of Biblical Tradition 30) - may also contribute to a sense of its being too prescriptive or moralistic, of its not inviting a varied or dissenting reading. Essentially, 'allegory' has come to mean a text which is determined by its meaning - which in itself seems to be a category determined by the reader's position more than any imposition of the author. This may be why allegory has undeservedly received a reputation for didactic simplicity: "[i]n the wake of Romanticism moderns have tended to be averse to the intellectuality, didacticism, universalised significance, a-temporality, and hierarchically conservative tendency of allegory (preferring multiple rather than unified hierarchies)" (30). Such a disdain for allegory (which is at the root of a lot of the criticism, of Lewis in particular, on the part of Philip Pullman, Neil Gaiman, Naomi Wood, Laura Miller, and others), stems from a concern that allegory, rather than providing an opportunity to explore and interpret, would always be governed by rigid meaning. The feeling of being 'drawn in' is abhorrent to readers, 46 as Polly Toynbee points out in her 2005 response to The Lion, the Witch and the Wardrobe film, which she entitled "Narnia Represents Everything that is Most Hateful

\footnotetext{
${ }^{46}$ With amusing foresight (or personal pre-conversion experience) Lewis has even pre-empted Toynbee and the others by writing the same aversion in Perelandra: the narrator has an awful apprehension that he "might get 'drawn in'" (152) by Ransom's fantastic tales, and goes on to speculate "I suppose everyone knows this fear of getting 'drawn in' the moment at which a man realises that what had seemed mere speculations are on the point of landing him in the Communist Party or the Christian Church - the sense that a door has just slammed and left him on the inside" (152). While I believe that allegory is oversimplified and disdained undeservedly, it is still an incomplete and simplistic reading of the works of Tolkien and Lewis.
} 
about Religion." Some beautifully imaginative elements notwithstanding, she deems "the clunking allegory" to be "toe-curlingly, cringingly awful", and labels it an "arm-twisting emotional call" (Toynbee). The modern suspicion (and dismissal) of allegory is based on the idea that allegory is a message either crudely or cunningly disguised.

And it is this habit of dismissive association against which Tolkien and Lewis were writing. To my thinking, both authors opposed the label of 'allegory' so vehemently because of its less flattering, didactic connotations, and the modern distaste for allegory. ${ }_{47}^{47}$ They intended their methods to be experimental, explorative, creative, and the label of allegory would instead associate their fiction with finite, interpretative, and potentially even cunningly manipulative. Tolkien refuted the idea that his whole body of work was allegorical. Even Leaf by Niggle, the supposed self-allegory, Tolkien has said "is not really or properly an 'allegory' so much as 'mythical.' For Niggle is meant to be a real mixed-quality person and not an 'allegory' of any single vice or virtue" (Scull and Hammond 495). The distinction Tolkien makes between 'myth' and 'allegory' here is that the allegorical gives a single dimension of possible meaning, whereas he desired to write multi-dimensional characters with multi-faceted significance or 'applicability.' Scull and Hammond's Tolkien Companion further quotes Tolkien's instructions to his publisher advising against any allegation of allegory on the grounds that there is no more a definite 'moral' in his work than there is in any other tale worth telling (37). As he famously declared in his Foreword to the Second Edition of The Lord of the Rings, "I cordially dislike allegory in all its manifestations" (The Fellowship of the Ring xxii). He continues:

I much prefer history, true or feigned, with its varied applicability to the thought and experience of readers. I think that many confuse 'applicability' with 'allegory'; but the one resides in the freedom of the reader, and the other in the purposed domination of the author. (xxii)

It appears that Tolkien disliked allegory on the same grounds as the critics did: he disliked didacticism (or 'domination') on the part of the author. It is also evident that his attempts to write un-allegorically were intended to oppose an authorial prescriptive meaning. He insists that any allegorical reading is purely in the reader's power, should they choose to read symbolically or allegorically, rather than imaginatively engage in the experience.

The J. R. R. Tolkien Companion and Guide also notes Lewis's take on the issue when he wrote to Tolkien on the subject of allegory in Tolkien's fiction, and can be taken as Lewis's answer to what he believed were false accusations of his own allegorising:

The two things that come out clearly are the sense of reality in the background and the mythical value: the essence of myth being that it should

${ }^{47}$ Perhaps Tolkien and Lewis do 'protest too much' - possibly a clue to an orientation they wished to hide. 
have no taint of allegory to the maker and yet should suggest incipient allegories to the reader' [...]. A strict allegory is like a puzzle with a solution: a great romance is like a flower whose smell reminds you of something you can't quite place. I think the something is 'the whole quality of life' as we actually experience it. (39)

His suggestive or 'incipient' allegory is another iteration of what Tolkien might rather have labelled a story's 'applicability' or 'relevance.' The point Lewis makes is that these connections should be implicit and nuanced, rather than explicit in the way that a puzzle only has one right answer, showing thus how even allegory can work to defamiliarising effect. Lewis takes the view here, like Tolkien, that deliberate allegorical coding has no place in myth (nor in The Lord of the Rings). Both agreed that fantasy required a more multi-dimensional, suggestive force, rather than specific moral lessons, or personified virtues. Myth, or what they both might call fairy tale, is not so straightforward. Its character is less tangible and more ethereal. It produces a longing, but we know not what for. I pursue a reading of their work which opens up, exploring the vividness of their worlds, and their worlds' 'numinosity.' In so doing, defamiliarisation seems to me the more accurate and appropriate paradigm through which to view the works of Tolkien and Lewis.

To expand on an earlier point, so-called familiar Christian context and cultural knowledge is removed, killed off as it were, in order to be received anew, transformed, reborn in the cultural imagination. Because, as Milbank puts it, they wanted to re-introduce "a sense of the holy in an increasingly disenchanted and secularized society" (Chesterton and Tolkien as Theologians 7), 'making strange' was for theologically-inclined writers a kind of "rebirth" (38), "in order to be reborn as a miracle" (38). Only then could re-enchantment be effected, once an author had established "a religious fullness of experience that must be intellectually engaged and in some sense entered into" (9). Immersion in the aesthetic creation - some might call it the 'magic' of Middle-earth or Narnia - was the means by which these writers could achieve a sense of the holy in answer to the disenchantment of the age. This holiness may refer to spiritual holiness, but it may also refer to a willingness to entertain the fantastic in fiction, and thus to see the world as it was meant to be seen. Finally, if Tolkien and Lewis critics read their works expecting them to be allegorical (in the sense of being one-dimensional and exact, as Toynbee does), I believe that even applying the word 'defamiliarised' rather than 'allegorical' to the fiction of Tolkien and Lewis harmonises with their stated purpose of liberating their art from a certain type of dulled reading, allowing it to shimmer in the light of another world. 


\section{We Lose that We May Find}

To conclude, the methodological standpoint for this literary analysis of Tolkien and Lewis is largely informed by the concept of defamiliarisation. As I have demonstrated, defamiliarisation exists on a spectrum, comprising a variety of techniques. Although these can differ at one level, the intended results remain the same: prolonging the aesthetic by delaying automatic perception or preventing recourse to the familiar. While I embrace the theories of Shklovsky and Milbank, further categories are required if one is to take account of the techniques employed in the fantasies of Tolkien and Lewis. The value of an analysis of defamiliarisation in their fiction is that it provides the framework of both the concept of defamiliarisation (as a means of describing literary creativity from a Christian perspective) and the practice (as a means for conveying theological ideas). Thus, the crux of my critical reading is not so much biographical or theological, but rather focused on what might be termed a 'theological aesthetic': taking seriously what each author set out to do (in their own words), to see if they had done it. Many works already exist that trace the biographical/theological connections and literary influences on these fantasies; I examine the theological links as if they were literary. As such, I will be analysing their methods as they pertain to their process of (subJcreating Creation narratives in Chapter One. This will set the theological tone for this research, as these narratives are governed by the Christian view of Creation. In Chapter Two, I explore the use of ambiguity and riddle in their fiction, expanding my theory of defamiliarisation to include the authors' efforts to make room for the reader to discover and collaborate in the meaningmaking of the text. For the writer, making strange serves to make new, and means creatively redirecting their writing away from the familiar, the expected, or the cliché. My own definition of defamiliarisation may therefore be understood in two categories: those pertaining to the writer and those pertaining to the reader. Whatever form it takes, defamiliarised writing requires nuance; it is suggestive rather than definitive, so the reader is required to riddle through for themselves the mysteries of unresolved character ambiguity, unreliable narrators, and other masking techniques. The reader is positioned so that their artistic experience of the text is prolonged, and they themselves must contribute artistically to the imaginative world. The reader works through the difficulty of unfamiliarity, contributing an artistic and imaginative vision, exploring the infinite possible aesthetic meanings of the text. Conversely then, in Chapter Three, I examine the authors' complex use of finite archetypes to defamiliarise traditional characterisations of Christ, particularly through typological patternings of Adam and Christ in their protagonists. Lastly, as defamiliarisation has a restorative effect on what it defamiliarises (enriching the familiar by making it strange for a time), Chapter Four examines the literalisation of Biblical imagery, particularly as it pertains to death, resurrection, New Creation (as in Revelation), and beyond. This chapter deals with the subversion of the secular idea of physical 
death, so that it is seen as a route to new spiritual (after-)life; it also isolates (more generally) the paradox of endings as new beginnings.

Lastly, I argue that, whether by Shklovsky's original technique, or its iterations in the work of Tolkien or Lewis, defamiliarisation makes itself apparent as the most appropriate method for the portrayal of divine subject matter. The unknowable God can be only partially invoked by techniques which suggest but do not conclusively define. Much has been made, for example, of Tolkien's reliance on the idea of 'beyond', of stopping short of attempting to describe things that were 'beyond description'. Verlyn Flieger notes that the very reason one can find evidence for such widely differing readings of Tolkien's works - from Christian, to pagan, to humanist, to hippie readings - is because "Tolkien opens the door to both" traditional and unconventional readings ("But What Did He Really Mean?" 151). Flieger likens it to Bottom from A Midsummer Night's Dream, waking from enchantment "trying to describe the indescribable" (158).48 What is essential is awareness of the gap, of what is left undescribed. The importance of an invitational, experimental, or explorative technique of defamiliarisation cannot be overstated, because it is this aspect of the fiction which is most indicative of an unattainable 'beyond'. By exploring defamiliarisation in fantasies so familiar to the reading public, a fresh paradigm is opened, through which the creativity of Tolkien and Lewis might be examined and appreciated anew. Perhaps then, the reader might hope to recapture (restore) some of their original potency.

${ }^{48}$ Cf. "The Man Born Blind", a story attributed to Lewis, later republished as "Light." 


\section{Chapter One: The Beginnings of Defamiliarisation: Creation, Sub-creation, and Fantasy}

Defamiliarisation is not only a linguistic technique; it is a world-building technique. In one sense, fantastic creation is the natural answer to Shklovsky, for fantasy worlds are in essence a re-creation, or defamiliarisation, of reality. Middle-earth, Narnia, and others are worlds of myth and fairy tale in which a world that might otherwise be mistaken for ours remains removed from familiarity, so that everything in it appears enhanced, made numinous, made new. This chapter ${ }^{49}$ explores the genesis of these fantasy worlds in order to understand the aesthetic choices that have been made, and how they imbue familiar things with such potency.

The first few pages of a fantasy novel are crucial in introducing the defamiliarising project, establishing both the world itself, and the conditions through which the reader (and the characters) experience that world. Once the realm of fantasy is introduced in Tolkien's The Hobbit (1937) and Lewis's Out of the Silent Planet (1938) and The Lion, the Witch and the Wardrobe (1950), the defamiliarising project of Tolkien and Lewis can be analysed under the headings of the names they gave for their creative techniques: 'sub-creation' and 'supposal' respectively. These views inform and shape the mediating role of the storyteller as an agent of defamiliarisation with a particular audience in mind. The Genesis story of Creation itself becomes the site of defamiliarisation as each author defamiliarises Creation into the creation story of his own world. Their defamiliarisation is coloured in each case by their theological and artistic concerns, illuminating both the process and product of their writing: defamiliarising Creation as artistic creation. In their accounts of the creation of Middle-earth and Narnia, both based upon the model of Genesis 1, Tolkien and Lewis defamiliarised the act of speech-creation into music, emphasising harmony, ${ }^{50}$ artistry, and the spectacle of creation. Their belief in the artistic character of God extends to his creation, namely humanity, so that their own poetic art is

${ }^{49}$ Some of the material appearing in this chapter has been accepted for publication by Fantasy Art and Studies - Les Têtes Imaginaires edited by Viviane Bergue, Issue 10, June 2021, under the title "Singing into Being: Defamiliarisation as Creation in J. R. R. Tolkien and C. S. Lewis".

${ }^{50}$ In "Mythopoeia" Tolkien conceptualises evil as discord, for example: evil lies "not in God's picture but in crooked eyes, / not in the source but in malicious choice, / and not in sound but in the tuneless voice" (149-151). 
reflective of God's, and seeks to restore wonder to the Biblical account of Creation even as they build from their own power of invention.

\section{Beginning with Defamiliarisation: Entering Faerie}

Although an important aspect of defamiliarisation-as-creation, accounting for the creation of the fantasy world is not where the authors begin. The introduction of the reader, or indeed the characters, into the fantasy world is the first and most compelling touchstone, where the defamiliarising really begins (or at least is signalled): the point of entry to the faerie realm. Tolkien's The Hobbit (1937) and Lewis's The Lion, the Witch and the Wardrobe (1950) provide excellent examples of how the project of defamiliarisation is signalled in the very beginning, alerting the reader to a different, more numinous reality.

To illustrate this, consider this brief gloss of what aesthetic decisions were made to make the fantasy worlds appear so 'magical' at first glance. In just the first chapter, Tolkien's The Hobbit has all the trappings of a solid adventure tale (the mention of an adventure being organised not least): the talk of a dragon, treasure maps, and the prospect of the uninitiated earning his stripes. The narrator of The Hobbit assumes the reader is familiar with the (un)familiar world of the hobbits. There is a brief description of the hobbit holes, but the narrator quickly excuses his own explanatory inclination, saying "I suppose hobbits need some description nowadays, since they have become rare and shy of the Big People, as they call us" (16). This conversational tone is specifically geared toward children and makes much of what they would find humorous - the good morning exchange, ${ }^{51}$ for instance, and the delightful idea of an adventure in a fantasy realm with a protagonist (Bilbo) who is decidedly unadventurous. "Nasty disturbing uncomfortable things!" Bilbo says of adventures, "Make you late for dinner" (18). Part of the immediate appeal of this story is the odd-coupling, both of Bilbo and Gandalf, and of Bilbo and his adventure. Even the words Bilbo uses to disparage adventures would strike a child as those of a rather amusing parody of a parent figure. The Hobbit is moreover a singular example in Tolkien's legendarium (which would have been well established, though as yet unpublished, in various drafted short stories, sagas, languages, and histories), in the way that it dwells on the light and simple: the lavish descriptions of food, the silly rhyming songs about poor table manners, ${ }^{52}$ and Bilbo leaving his house in such a rush that he forgets his handkerchief - all of which, notwithstanding the presence of the hobbit and dwarves, are utterly everyday

${ }^{51}$ After Bilbo 'good mornings' Gandalf, the latter replies: “What do you mean? [...] Do you wish me a good morning, or mean that it is a good morning whether I want it or not; or that you feel good this morning; or that it is a morning to be good on?" (17-18), and so on.

52 That is, the song about "what Bilbo Baggins hates" (25), not the austere 'Misty Mountains' song (27-28). 
and familiar. Likewise, Middle-earth is familiar, as landscapes go, as the countryside of England (or New Zealand for that matter), and yet is immensely evocative. In short, Tolkien ensures that the child reader is captivated straightaway by his defamiliarised world, keeping a careful balance between the known and the unknown, the recognisable and the unrecognisable.

Lewis in his turn does the same with The Lion, the Witch and the Wardrobe. The book begins with the children's removal from London to a grand, old country house, and the prospect of their own modest adventures in the grounds are already a promising premise for a children's book (as Enid Blyton tropes go). There is then the further removal into the realm of faerie, even more thrilling for being unexpected: readers (like the protagonists) thought they were in for a completely different tale. The world of Narnia, found through the magical wardrobe, has mythical creatures - creatures moreover to whom humans are mythical. ${ }^{33}$ Narnia's snowy landscape may even be capitalising on the 'winter wonderland' imagery of Christmas, popular around 1947,54 which is not so extraordinarily magical on its own (the winter of 1946-47 was also one of the worst for years in the United Kingdom). Yet the wintry Narnian landscape resonates so vividly and so long in the imaginations of its readers for its strangeness, the sudden and complete departure (via a wardrobe no less) from the 'ordinary.' Narnia represents all that is extraordinary, defamiliarising even the notion of time (Lucy is in Narnia for a whole afternoon, but returns through the wardrobe after only a few moments have passed). Lewis sets up a contrast between school and the empty room, the known and unknown, juxtaposing two very different contexts.

These charming details notwithstanding, both Tolkien and Lewis were thoughtful and deliberate about how their readers first encountered these numinous worlds. One way Tolkien manages the reader's encounter with fantasy is through his narrative voice. The Hobbit is immersive fantasy, beginning as something like an archivist's recording of real events. In Rhetorics of Fantasy (2008), Farah Mendlesohn defines immersive fantasy as "a fantasy set in a world built so that it functions on all levels as a complete world [...] as if it is impervious to external influence" (59). ${ }^{55}$ Immersive fantasy spends little time acclimatising the reader to the

\footnotetext{
53 There is even a book called Is Man a Myth? on Mr Tumnus's bookshelf (The Lion, the Witch and the Wardrobe 19).

${ }^{54}$ In Sleigh Rides, Jingle Bells, \& Silent Nights, Ronald D. Lankford writes that the popular song 'Winter Wonderland', which was originally a romantic song, saw a change around 1947 so that it "segued from a romantic winter interlude to a seasonal song about playing in the snow" (Lankford 110).

${ }^{55}$ In fact, Mendlesohn does not classify Tolkien's works as immersive, but rather as portal-quest fantasies (though in a different register) because Frodo and Bilbo move from a known "understood" (albeit fantasy) world to "the wild, unfamiliar world" (3), so most of the book "takes place in a world strange to the protagonists" (67). While Mendlesohn does acknowledge the difference between The Silmarillion (which is "told 'from the inside"' (67)) and The Lord of the Rings (which is not), she believes Tolkien is not 'immersive' as such, what with his narrative inclination "to describe or explain what is seen" (xx). I am
} 
new world. Tolkien's narrator does not establish the fantasy (with phrases like "once upon a time there was such a thing as hobbits"), nor does he make use of a magic portal (such as a wardrobe). Rather, he assumes the tone of an amateur researcher relaying incidental historical fact. He takes their world for granted: "In a hole in the ground there lived a hobbit" (The Hobbit 15). This educational narrative voice introduces hobbitry from a slight distance: if the reader were already familiar with hobbits and their holes, there would be no need for the second sentence to clarify, "Not a nasty, dirty, wet hole, filled with ends of worms and an oozy smell, nor yet a dry, bare, sandy hole with nothing in it to sit down on or to eat: it was a hobbit-hole, and that means comfort" (15). This precision further reinforces the immersive effect: it assumes an audience that appreciates that Middle-earth has a variety, not only of hobbits, but other inhabitants too. Even though the narrative voice in The Hobbit begins in a more conversational, informational way, it moves into a grave, mythic, almost prophetic voice (more akin to that of The Lord of the Rings), implying the speaker has direct access to that far-off realm. Tolkien explained this tonal discrepancy to one of his readers, saying that

this is a study of a simple ordinary man, neither artistic nor noble and heroic (but not without the undeveloped seeds of these things) against a high setting - and in fact (as a critic has perceived) the tone and style change with the Hobbit's development, passing from fairy-tale to the noble and high and relapsing with the return. (Letters 159)

Because the tone of his writing is fluid, adapting to the mood and the narrative (rather than the age of the audience, for example), Tolkien makes it very clear that fantasy is not only child's fare. What marks his technique out is the pseudo-scientific storytelling. This point could be perhaps even better made by the sixteen-page prologue ${ }^{56}$ (of little to no narrative import) concerning hobbits, presented with a researcher's devotion, for his reader to "discover much of their character and a little of their history" (1). The reader is introduced to the fantasy world in such a way as to convince them that what follows is historical retelling, as if this fantasy is perfectly

inclined to disagree. There is no device or magic door or the like to function as a portal. At the very least, I take Tolkien's writing style to be 'immersive' if not the actual features of his fantasy. If it were completely immersive, however, there would be no place for narrative interventions such as Tolkien's interesting (even occasionally anachronistic) narrative interjections (which are very much an intrusion of some 'external influence' on the world of Middle-earth). I nevertheless understand Tolkien's narrative interpolations to be a deliberate aesthetic, more that of an historian or an educator's enthusiasm, than non-immersive. Immersive fantasy, for example, consciously avoids a sense of wonder and Tolkien's books accord with this: there is no call to wonder at the existence of magic, for the fantasy world of the story is taken for granted, in a way that it cannot be in portal fantasies. As Francis Spufford has said, you travelled to Middle earth in the imagination, and the "richness" of these worlds "did not call to you at home in any way. It did not lie just beyond a threshold in their world that you might find if you were particularly, or particularly blessed" as does Narnia (The Child that Books Built 85).

${ }^{56}$ Not all editions have this version of the prologue, which was moved around in the first few chapters, added to, and changed in the early publications. The prologue I refer to here is from the 2012 HarperCollins boxset edition, first published in this format in 1966. 
ordinary. This in itself gives Tolkien's defamiliarisation something of an authoritative appeal to reality even as it clearly announces its fantastic strangeness.

Even the map frontispiece has an objectifying function and is part of the illusion. Maps of fantasy lands are so commonplace in modern fantasy (maps themselves are a trope frequently signalling fantasy ${ }^{57}$ ), because they are so effective in situating the reader immediately in a defamiliarised geographic location. Tolkien's map makes use of tiny illustrations of landmarks (like cities and mountains), rather than dots and contour lines, ${ }^{58}$ making the result more mythic than precise: it is a map in a sense, but not as any modern cartographer would understand it. The map does not completely estrange: the reader is somewhat acclimatised to the new landscape through the use of familiar geographical features, such as mountains, oceans and the like. Yet, the readers cannot place the landmarks on any known map of earth. For Tolkien, the map was part of his imbuing his fantasy with such a "consistency of reality" ("On Fairy-Stories" 43) as to blur the distinction somewhat between reality and enchantment, thereby balancing the evocative and the precise.

Tolkien's found-manuscript techniques are not uncommon among writers of fantasy. Tolkien refers to the source manuscript as "composed by Bilbo himself" (The Fellowship of the Ring 1). It is a fascinating kind of defamiliarisation, to deliberately depart from the 'normal' world, but then to pass off the fantastic as realistic, and to pass off fiction as historical. In fact, part of the feeling of wonder on encountering the world of hobbits, wizards, dwarves, treasure maps, and dragons is due to its being presented as normal. Tolkien's tone suggests that should you choose to venture out into nature looking for hobbit-holes, you may well find them. He does not merely testify to the wonder of this enchanted world, but imbues the real world with a kind of enchantment too - but a faded enchantment, a hint of what it once was. Tolkien makes a world outside of our perception seem possible, even probable, if just beyond our ability to perceive it.

The insinuation of factuality is a technique that Lewis also uses in his Space Trilogy through the character of Ransom, though it is by no means characteristic of all his fantasy. Lewis concludes Out of the Silent Planet (1938) with a postscript implying that no effort has been spared to preserve the accuracy of the account. This postscript is supposedly taken from letters written by Ransom to Lewis, with details pertaining to the authenticity of the story. Lewis thus casts himself as a kind of ghost-writer for the story. He pretends that he has written down

\footnotetext{
${ }^{57}$ Some maps provide valuable information. Paul Stewart and Chris Riddell's The Edge Chronicles, for instance, each contain a distinctive map frontispiece cueing their readers into key features of the fantastic before even a word of the narrative: the city of Sanctaphrax floats, for example. ${ }^{58}$ Something similar can be seen in tourist brochures and children's books.
} 
Ransom's true story, but marketed it as fiction; he writes: "our only chance was to publish in the form of fiction what would certainly not be listened to as fact" (139). There is a double bluff here, as Lewis pretends to fictionalise a true event, which was his fantastic creation to begin with. This device brings up several fascinating ideas. Presenting 'truth' as fiction is something Lewis-the-character does with Ransom, but it also sheds light on a technique he uses himself as an author: fictionalising the 'real' to draw the open-minded reader's attention to the aesthetic truthfulness of a story first, rather than directing them to examine claims to scientific truth. Certainly, this suggests a sentiment that rings true for other of his fictions, such as his Narnian books, although it is not so explicit: for example, Lewis deals with the probability of fantastic worlds existing, through Professor Kirke's mutterings about logic (The Lion, the Witch and the Wardrobe 47-49), but treats these mutterings as sufficient and does not direct the reader's attention to any scientific claims as some science fiction writers would. Lewis defamiliarises because the fictional settings engage the imagination first rather than foregrounding any other ideological claims. Hence, he writes a theologically profound text which is intensely imaginative, set beneath the pink skies of Malacandra, with purple mega-trees, and fantastic beasts such as eldila, hrossa and pfiftriggi with their complex and other-worldly languages, to make the strange world (and not its truth claims) the most compelling feature of the tale.

Expert in various fantasy genres in his writing career, Lewis has proven himself capable of drawing a reader into the fantastic in various ways that are unique, even from each other. After the success of the wardrobe as portal in the Narnia series, for example, he never again returned to that trope, as other authors have done. ${ }^{59} \mathrm{He}$ constantly varied the way he wrote his fantasies, so that in a sense he defamiliarises even from his own previous methods. His ringing the changes is itself a deliberate refusal to meet any expectations about the environment or setting. Many of his pre-Narnia fantasies, however, have in common a varying bid for authenticity. Ransom's postscript in the Space Trilogy gives the impression of fact that has been fictionalised (and not the other way around), as I have mentioned, and so the narrative voice works hard to explain to the earth-bound reader the strangeness of unseen planets and futuristic science. The supposed authenticity of Ransom's account was initially considered as a way to authenticate the letters of Screwtape: in an abandoned version of the preface to The Screwtape Letters, Lewis pretended to have come across Screwtape's correspondence via Ransom and his visits to other worlds. Even though that claim was abandoned in draft form, what remains is presented as evidence of a real correspondence: "I have no intention," writes Lewis in the current preface, "of explaining how the correspondence which I now offer to the public fell into my hands" (ix), and he goes on to apologise for not clearing up the chronology (of

${ }^{59}$ Such as Lynne Reid Banks did very successfully for her The Indian in the Cupboard series. 
what are, it must be remembered, fictional letters). It seems to be a favourite method of his, this insinuation of factuality in some form or another. Even the more immersive fantasy myth Till We Have Faces (1958) features an author who appears dedicated to authentic telling. Some of the first words of Orual's narrative address the reader directly, implying an almost legal interest in accuracy. She writes "I will tell all he [the God of the Mountain] has done to me from the very beginning, as if I were making my complaint of him before a judge" (11). She presents the book as a considered correction of a popular falsehood - never mind that her tale, and the one she means to correct, are both Lewis's fictions. Only once does Lewis use the conceit of it-was-all-adream, in The Great Divorce (1946). Yet the book for which Lewis is most well-known does not even begin with a claim to authenticity. The Lion, the Witch and the Wardrobe, first published in 1950 , is a quintessential portal fantasy, ${ }^{60}$ in which Lewis does not try to provide proof for the fantastic, but rather leans entirely into the 'magic' of the fantasy world.

In popular representations, Narnia is most commonly associated with fairy-tale wintry woods and with the lamppost in the clearing (even though the winter was supposed to be the Witch's curse rather than a fairyland enchantment). What then makes it so beloved? To many child readers around the world, perhaps, it is the snow. For those living in warmer climates, like myself, snowy Narnia is magical for being exotic: a sparkling wonderland relegated to the realm of faerie, Christmas cards, and the exotic lands collectively named 'overseas.' The winter is also associated with Christmas festivities. Even if snow is not a novelty for the characters (or indeed the readers), it is fantastic because Lucy has just come from summer, on the other side of the wardrobe (17). Whatever familiar setting Lucy came from is defamiliarised: summer to winter, day to night, boredom to excitement, predictable to unpredictable, ordinary to extraordinary. What gives this otherwise natural landscape its enchantment is the wardrobe. The transition is made by passing through a wardrobe, with fur coats metamorphosing (punningly) into fir trees. No special mention in the narrative beforehand or special design marks the wardrobe out.61 Nothing more than a little curiosity even draws Lucy to it. She and her siblings are after all in a stranger's house, evacuated because of the war, and forced indoors because of the weather. The humdrum atmosphere of the children's exploration of a strange house is suddenly disrupted when Lucy peeks inside a perfectly ordinary wardrobe, and stumbles into Narnia. Nothing so far

\footnotetext{
${ }^{60}$ Mendlesohn defines both portal- and quest-fantasies as those in which "a character leaves her familiar surroundings and passes through a portal into an unknown place" (1).

${ }^{61}$ There is nothing in the original of the visually compelling, ornate beauty of the wardrobe in Andrew Adamson's 2005 film adaptation. The wardrobe prop was even carved with scenes from The Magician's Nephew (1955), the prequel Narnian story, which tells of the origins of the wardrobe, and deliberately placed in the room so that all the lines in the panelling drew the viewer's eye toward it.
} 
in the narrative would have led the reader to expect this. The ordinariness which masks the extraordinary is all part of the appeal.

The success lies in its unexpectedness. Even reporting the magic in a matter-of-fact manner off-sets the magical nature of it all even more. Neither Lucy (whose free indirect discourse follows below) nor the reader expects it:

Next moment she found that what was rubbing against her face was no longer soft fur but something hard and rough and even prickly. 'Why, it is just like the branches of trees!' exclaimed Lucy. And then she saw that there was a light ahead of her; not a few inches away where the back of the wardrobe should have been, but a long way off. Something cold and soft was falling on her. A moment later she found that she was standing in the middle of a wood at night-time with snow under her feet and snowflakes falling through the air. (The Lion, the Witch and the Wardrobe 13)

Who would not thrill to read it? Her world transforms dramatically from the wardrobe in a spare room to a clearing in a snowy wood, with a cheerfully shining lamppost and a faun with a scarf and an armload of parcels. The immediate appeal is the sheer fascination of the rapid transition from bare room and uninspiring prospects (a rainy day and far from home) to an enchanted wood in a different world - and perhaps the reason this is one of the most enduring images of Narnia in the cultural imagination. For clearly the world Lucy comes from and the one she enters into are vastly different. She is a Londoner removed not only to the English countryside, but further, she suddenly finds herself in the deep woods of a magical land. She has gone from modern warfare to magical curses; from modern city to enchanted woods; summer to winter; day to night; human society to the society of mythical creatures. The difference could hardly be starker. Lewis firmly sets aside the narrative's introductory red-herring that this will be a schoolchild story about wartime evacuation. The children's earlier speculation about exploring the mountains and seeing the animals in the countryside (10) - stags, hawks, badgers, foxes and rabbits, oh my! - is another deliberate misdirection, calling to mind narratives falling into the familiar formula of delicate or spoiled city children learning manners and wholesome outdoor values in the country. ${ }^{62}$ Although the children do encounter various animals in Narnia, they are talking animals: the beavers are friendly, rustic folk, but the wolves are secret police in the employ of a dangerous dictator. As defamiliarising from the ordinary goes, Lewis's first chapter certainly does a complete about-face.

Portal entry into Narnia is a recurrent device, as has been mentioned, but even the portals function in unexpected ways, and entry to Narnia is not always gained through portals.

${ }^{62}$ See, for example, any Enid Blyton book, probably with the word 'Farm' or other pastoral word (like meadow) in the title. The Children of Cherry Tree Farm, The Children of Willow Farm, and Six Cousins particularly come to mind. 
Indeed, as portals go, even the wardrobe does not function consistently as a portal into Narnia. Lewis, without explanation, opts for unpredictability. He suddenly strips the extraordinary wardrobe of its magical function, and some other attempts the Pevensies make to find Narnia again prove unsuccessful. The wardrobe defies expectation even in the book. Lucy goes through and comes back once without any trouble, and yet when she returns to show the others, she discovers to her dismay that it has reverted to an ordinary wardrobe. What she has taken for granted, even if magical, cannot be relied upon; what we take as a law does not apply. As with the portals in the following Narnian books, there is no way to predict how and when portals might appear or function. Even these are defamiliarised from each other; Lewis makes a point of avoiding sameness. Indeed, the Professor advises the children after they return from the wardrobe at the end of The Lion, the Witch and the Wardrobe, "Yes, of course you'll get back to Narnia again some day. [...] But don't go trying to use the same route twice. Indeed, don't try to get there at all. It'll happen when you're not looking for it" (170). The transport to Narnia in the immediate Narnian sequel Prince Caspian (1951), as beautifully invoked by the 2008 film, does not involve a portal at all. This time, the magic that draws the children into Narnia does not feel so friendly and benign. Lucy shrieks as if she's been stung. Susan and Peter feel something powerfully tugging on them. Lucy even cries out "I can't bear it" (12). The unextraordinary station where they are gathered, about to leave for the school term, simply vanishes and they find themselves in a prickly thicket on a seashore. In contrast, the film rather beautifully and dramatically has the station peeling and flashing away, revealing the gorgeous sunlit paradise of the Cathedral Cove beach in New Zealand, but Lewis's version has them suddenly on a wild coastline, stung by nettles, abandoned and helpless in an unknown place. Gradually they come to recognise it as Narnia, several hundred years after their previous visit, but that doesn't detract from the feeling of being "shipwrecked", as Edmund says (14), and neither does it detract from the imminent shortage of food and shelter. This Narnia is now more like Robert Louis Stevenson's Treasure Island or Daniel Defoe's Robinson Crusoe than an Enid Blyton-esque romp, and more dangerous. There are no (seemingly) friendly fauns to invite them over to tea by a cosy hearth. Given the theological overtones of the books, perhaps one could draw a parallel between the unpredictability of these fantastic intrusions and the role of divine providence in life (or artistic inspiration for that matter) - anything involving one's unexpected induction into transcendental reality. Lewis nevertheless consciously writes to prevent any readerly (over-)familiarity.

Having made sure that the way into Narnia cannot be predicted (either by the characters or the readers), Lewis returns to the portal trope - but is not bound by it - in The Voyage of the Dawn Treader (1952). Lucy, Edmund, and Eustace enter Narnia via a painting of a ship that 
looks "very Narnian" (10). The life-likeness of the painting is what draws Lucy to it, and gradually the ship and the wind and the waves seem to come to life: the noises of the wind and the waves begin to roar in their ears, and the sea spray splashes them, and the pages of an exercise book flap and fly away in the gust. Frightened, their cousin Eustace rushes forward to smash the picture, but it is as if it swallows them up:

And by this time either they had grown much smaller or the picture had grown bigger. Eustace had jumped to try and pull it off the wall and found himself standing on the frame; in front of him was not glass but real sea, and wind and waves rushing up to the frame as they might to a rock. [...] [Then] a blue roller surged up round them, swept them off their feet and drew them down into the sea. (12)

This is not the gentle doorway of the wardrobe, whose summertime daylight can be seen even from the winter woods of Narnia. Previously, Lucy's role had been an active one in choosing to go through the wardrobe, whereas this time she is more passive, involuntarily swallowed by Narnia's otherworldliness. This is a portal so consuming that the reality of the painting seems to overwhelm the reality of their own world. There is no looking back through the painting, as if "the picture frame [could be seen] hanging above the sea" with "a glimpse of Lucy's bedroom" (14); it was gone. There is nothing but blue sea in all directions, "without a break to the horizon" (14). Every time a reader picks up a new Narnian chronicle to read, the rules are not the same as the previous one, thereby prohibiting a too-ready familiarity. First, as discussed earlier, there is the wardrobe which facilitates several visits at unpredictable intervals (but appears to remain open for return whenever the children head homewards), and Voyage of the Dawn Treader has them overcome by the different reality in the painting. In another chronicle, The Magician's Nephew, it is a malevolent uncle's occult experiments with magic rings that send children to a portal limbo space that is not even Narnia (30-31). Likewise, in The Silver Chair (1953), the children arrive in a magic place (not quite Narnia) beyond the gate in the stone wall of their school (18), whilst trying to evade some school bullies. Once again, this is not Narnia as we know it, but a mountain outside of Narnia where they meet Aslan, who sends them to Narnia on his breath. The children, furthermore, break portal tradition by being the ones who call on Aslan first, requesting to be taken to Narnia (16). The Horse and His Boy (1954) does not even feature the portal entry from another world: it is the only one of the chronicles to be completely immersive fantasy. It further defamiliarises in that it does not take place in Narnia at all, but the neighbouring land of Calormen. Lewis has removed the necessity of transportation to Narnia altogether. In The Last Battle (1956), Lewis reverses the order of the children's entry into Narnia by having Tirian, the Narnian king, attempt to summon the children himself (45). Previously, in Prince Caspian, it is revealed that the children have actually been summoned by a magical horn that Susan carried as queen, yet events are told from the children's perspective. In 
The Last Battle, however, Lewis tells the story mostly through King Tirian, and without a magical device this time. He calls first on Aslan, then on the children, and shortly afterwards they plop down unceremoniously beside him (47), having seen a vision of him in their world. Moreover, the children do not leave Narnia, after this adventure, to return to the real world: at the end of the story we discover that, back in England, the children have died in a train accident. Lewis has ensured that no entrance into Narnia, for character or for reader, is ever the same. Fantasy may be a defamiliarisation of reality, but Lewis even troubles to defamiliarise the points of departure from reality, so that the entrance into the fantasy realm cannot become familiarised through overuse. 63

Additionally, Lewis characterises Narnia differently on every visit in each book. The winter wonderland of The Lion, the Witch and the Wardrobe never returns. In The Magician's Nephew, the children happen upon Narnia not in winter, but part-way through its creation. Lewis's protagonists in The Horse and His Boy and The Silver Chair travel to such outlying parts of the Narnia territories that new maps needed to be drawn for these books. For the majority of the narrative, the latter takes place in the wastelands to the north, which seem to be outside of Narnia itself, and the former takes place in the neighbouring country to the south - seemingly neither is actually a Narnian book at all. The same may be said for The Voyage of the Dawn Treader, in which the characters travel to far-flung islands many weeks' travel off the Narnian coast. The maps are also an unusual addition, for the original book has no map, and the geography of The Lion, the Witch and the Wardrobe (although hardly necessary to comprehension of the story) must be inferred from the map in the sequel, Prince Caspian, which depicts a Narnia that is several hundred years older: where the beavers' dam once lay, for example, the Telmarine castle has been built, the location of the stone table is now a barrow, or burial mound named Aslan's How. Lewis has literally undertaken to trouble any sense of retreading familiar territory between his Narnia books. For one thing, the passing years between visits have rendered the Narnia of Prince Caspian and The Last Battle so different from previous visits that the children scarcely recognise it - in fact, in Prince Caspian, the children must constantly reroute their journey because the landscape has changed: not only in name, but sometimes also in geographical feature, such as a river turning into a gorge. The transformational nature of Narnia over the course of the Chronicles extends even to the level of genre: one of the chronicles is a portal-fantasy; another is a sea-faring, swashbuckling odyssey;

\footnotetext{
63 The portal device is used to great effect by other children's fantasy authors, such as J. K. Rowling, whose use of it is conspicuously different to Lewis. The portal remains constant in Harry Potter: the same train platform always leads to the same destination. In the ensuing adventures, of course, there are plenty of different portals; however, Rowling seems to have tried very hard to keep the portal of Platform 93/4 familiar and reliable.
} 
another is scientific exploration and experimentation going back to the dawn of time. ${ }^{64}$ The fantastic mode is enough to qualify as defamiliarisation (of reality), but Lewis has nevertheless not been content to let his defamiliarising end there. He has gone to great lengths to ensure that even though the idea of Narnia is familiar to his readers - the books are styled as the Chronicles of Narnia after all, and however each instalment begins the reader knows they must reach Narnia at some point - Narnia is not once found as it was left.

\section{Defamiliarising as Tolkien's Sub-Creation}

This brings us to the defamiliarising creative manifestos of Tolkien and Lewis, and to the question of why they should choose to defamiliarise as they have done. My introduction explored how their ideas correspond with Shklovsky's defamiliarising motivations; now, I wish to further expound the notion of sub-creation, articulated by Tolkien, to which both he and Lewis subscribed. Sub-creation is a legitimate example of defamiliarisation, albeit under a different name. The sub-creation approach moreover is itself an act of creation, involving many hues, infinite possibilities, the building of the world, and filling it. ${ }^{65}$ For Tolkien, the purest (indeed, the only) form of creation is the divine creation: creating all from nothing. The highest a human artist can therefore aspire to is sub-creation. It is a theological position with an aesthetic outlook: the limitless re-imagining of what already exists. In his seminal Andrew Lang lecture "On Fairy-Stories" (1939) - which interestingly predates the publication of all of C. S. Lewis's fiction, and nearly all of Tolkien's own (excepting The Hobbit in 1937) - Tolkien uses the example of mixing primary colours to articulate the endless combinations that can be derived from things in the primary world - as if creating "new" secondary colours ("On Fairy-Stories" 44). Sub-creation aspires to great and intricate creativity. This creativity which flows into us to create us, Tolkien suggests, also flows from us, producing art that is endlessly unique, a "tribute to the infinity of His [God's] potential variety, one of the ways in which indeed it is exhibited" as Tolkien would say (Letters 188). In this sense, art testifies to its own creation. I would contend that, for both Tolkien and Lewis, their theories of creative artistry derive from their theology of creation.

\footnotetext{
${ }^{64}$ The Lion, the Witch and the Wardrobe, The Voyage of the Dawn Treader, and The Magician's Nephew respectively.

${ }^{65}$ For further reading, see also: Dimitra Fimi and Thomas M. Honegger, Sub-creating Arda: World-building in J.R.R. Tolkien's Work, its Precursors and its Legacies (2019); and Mark J. P. Wolf, Building Imaginary Worlds: The Theory and History of Subcreation (2013).
} 
Tolkien set out these ideas in the poem 'Mythopoeia,' which has become known as his creative manifesto. These ideas would go on to influence even the creations of C. S. Lewis. ${ }^{66}$ The poem grew out of a conversation Tolkien had with Hugo Dyson and C.S. Lewis, and in it he describes his theory of artistic creativity as something which is always echoing the creativity of the Creator God. Tolkien explains that man's "world dominion [is achieved] by creative act" which is what allows him to retain a vestige of the lordship he possessed in his prelapsarian state ("Mythopoeia" 59):

Man is not wholly lost nor wholly changed.

Dis-graced he may be, yet is not dethroned, and keeps the rags of lordship once he owned, his world-dominion by creative act: not his to worship the great Artefact, Man, Sub-Creator, the refracted light through whom is splintered from a single White to many hues, and endlessly combined in living shapes that move from mind to mind. Though all the crannies of the world we filled with Elves and Goblins, though we dared to build Gods and their houses of dark and light, and sowed the seed of dragons, 'twas our right (used or misused). The right has not decayed. We make still by the law in which we're made. (lines 56-70)

Tolkien denies that artists have of themselves any absolute creativity: he did not believe that humans could make something of nothing. Mark Wolf notes that "the 'sub' prefix designat[es] a specific kind of creation distinct from God's ex nihilo creation, and [is] reliant upon it (thus 'sub', meaning 'under')” (Building Imaginary Worlds 6). A. N. Wilson puts it this way, that “[m]an's capacity to mythologise was a remnant of his prelapsarian capacity to see into the life of things" (C. S. Lewis: A Biography loc. 2347). In Tolkien's view, that is a godlikeness which humankind cannot aspire to. The human creator is but the 'refractor' of a 'single White.' Notwithstanding its 'subsidiary' form, Tolkien's sub-creation is not a limited or rudimentary artistic technique. Tolkien takes pains to emphasise the great possibility of sub-creation: "[w]e do not," Tolkien explains, "or need not, despair of drawing because all lines must be either curved or straight, nor of painting because there are only three 'primary' colours" ("On Fairy Stories", 51). Subcreation involves many hues, 'endlessly combined' as he says, which allows for the building and

66 The poem was in fact dedicated to Lewis, so there can be no doubt he was conversant with its themes. Its inscription reads thus: "To one [C.S. Lewis] who said that myths were lies and therefore worthless, even though 'breathed through silver'. Philomythus to Misomythus". Lewis's name was later inserted by the editors of the 1998 version of Tolkien's Tree and Leaf publication when the authors' letters came to light. Given his reputation now as a great storyteller, it is surprising to hear him described as Misomythus. Tolkien was specifically highlighting Lewis's aversion to and ignorance of the mythical quality of the Christian story. 
populating of endlessly unique worlds. He continues that it is "our right" to fill the crannies of the world with elves, and goblins, and dragons.

"The right has not decayed," he concludes, "We make still by the law in which we're made" (ll. 69-70). This couplet eloquently reveals several of the fundamentals of Tolkien's creative and theological philosophy as a writer. His ideas stem from the description of the creation of humanity in Genesis which describes man as "made in the image and likeness" of God (Genesis 1:26). Where humanity was made in the image and likeness of God, so Tolkien's theory of sub-creation posits making in the image and likeness of God as creator. I infer that what Tolkien is doing here with the imagery of his poem (and by extension, his creative work) is to describe a theory of sub-creation where man (made in the image and likeness of God) creates in that same image-bearing capacity. Furthermore, Tolkien writes that man, that is, humankind, has a power - albeit, according to Tolkien, a much reduced lordship - over creation, akin to that of the Creator. In The Road to Middle-earth (1982) which was one of the first scholarly works to seriously examine the creative (and philological) techniques Tolkien used in his fiction, Shippey paraphrases Tolkien's notion that "since the human imagination came from God, then its products must come from God too, must be fragments of some genuine if other-world truth, guaranteed by their own 'inner consistency' and no more the artist's own property" (211).67 Tolkien sees the artist as quasi-divine and unlimited in his sub-creation. It is clear from Lewis's letters and supplementary writing that he was conversant with Tolkien's sub-creative ideas and greatly admired them. Lewis's own theory likewise maintains a sort of sub-creative outlook. As Shklovsky wrote: "Art is a means of experiencing the process of creativity" (6); for Tolkien and Lewis, responding to and engaging with an all-creating God became an artistic endeavour. They reflected on the creativity of the Creator, by creating for themselves.

For Lewis, as for Tolkien, therefore, the act of creation was a way of performing theology. Tolkien once paraphrased G. M. Hopkins in a letter to Lewis, ${ }^{68}$ saying that "The only just literary critic is Christ, who admires more than does any man the gifts He Himself has bestowed" (Letters 128). Tolkien suggests here that the Christian's creativity not only pays homage to the creativity of God, but is pleasing to God, and moreover is "our right" ("Mythopoeia" 68). For Tolkien and Lewis, then, creatives and artists are, at the very least, pursuing a God-given mission in their creativity. An artist has the power to suffuse with suggestions of enchantment these things that God created; the artist's 'new' things spring from the manipulation of pre-existing things. In other words, the artist defamiliarises the existing in

${ }^{67}$ Although Shippey glosses the poem well, neither he nor Tolkien offer explanation for the existence of evil, though they acknowledge man is 'dis-graced' and 'dethroned'.

68 In Hopkins' original letter to R. W. Dixon in 1878, Hopkins was consoling Dixon for the lack of recognition Dixon had had for his own verse. 
order to make new. The only restriction Tolkien places on sub-creation is the necessity that the fantasy maintain some "inner consistency of reality" ("Of Fairy-Stories" 45); just because the worlds are invented does not mean that 'anything goes' (which was his objection to Narnia) or that things can happen arbitrarily.

The reason for this is so that the secondary world of the fantasy can be fully and imaginatively entered into without suspending disbelief to the point that certain physical laws (such as gravity or time) are called into question. Tolkien proposes a defamiliarisation of the familiarity of the primary world into a secondary, defamiliarised world, but this world is not entirely estranged from recognition. When the sub-creation is successful, it means that the creator has made "a Secondary World which your mind can enter. Inside it, what he relates is 'true': it accords with the laws of that world" (Tolkien, "On Fairy-Stories" 36). It maintains a shape and an internal logic so that it is still somewhat familiar to the extent that, like our world, it operates under certain laws. We do not have to recognise these laws - they can be quite unfamiliar - but what is familiar is that such laws must be observed. Wolf explains: "we imagine what the world would be like if it really existed, instead of simply ignoring the fact that it is only a story told in a book (or in other media)" (25). This makes Tolkien's sub-creative defamiliarisation almost playful: he is recreating by re-arranging. For example, he writes:

The mind that thought of light, heavy, grey, yellow, still, swift, also conceived of magic that would make heavy things light and able to fly, turn grey lead into yellow gold, and the still rock into swift water. [...] When we can take green from grass, blue from heaven, and red from blood, we have already an enchanter's power. [...] But in such 'fantasy', as it is called, new form is made; Faërie begins; Man becomes sub-creator. (25)

Here, Tolkien describes the imaginative power of words for the creator. A writer's very basic understanding of language can afford him or her the opportunity to play with ideas: what if the sky were green? What if solid rock became liquid water? The mere redistribution of description here captures the very essence of magic by re-imagining what is. Francis Spufford summarises it in this way: "From the moment humans had invented the adjective [...], they had gained creatorlike power to build elsewhere" (The Child that Books Built 82). Anyone "could use 'the fantastic device of human language' to mint a new coin for the imagination, such as the green sun" but to "sustain a world inside which the green sun was credible required a 'kind of elvish craft,' storymaking in its 'primary and most potent' mode" (83). Tolkien's own Middle-earth fantasy writings, while estranging themselves from the primary world of our experiences, by the species and histories there represented, for example, still maintain certain other laws, like that of gravity, ageing, and death. This sort of fantasy in storytelling he believes to be art in its "most nearly pure form", and at its "most potent" (44). In this way, the story demonstrates the shaping and intentionality of the author, for whom the act of creating is itself a godlike action. 
Another fascinating aspect of Tolkien's sub-creation is the internal creativity it displays. Many of the characters sing, tell stories, or are skilled inventors and craftsmen. Tolkien granted sub-creative powers to his own sub-creations. There are the Valar, for instance, who are somewhat angelic creatures with the ability to exercise authority in their spheres: it is a manipulation of the natural world that has more to do with "their Knowledge of the cosmogonical drama" (Tolkien, Letters 146) than magical conjuring from nothing. Tolkien described their making the three powerful gemstones - the Silmarilli - as an example in which "the sub-creative function of the Elves is chiefly symbolized" (148). These are more than "just beautiful things" (148); they are distillations of pure light. In other words, Tolkien's characters do not wield a sub-creative power that is a subordinate version of his own sub-creation, but are rather gifted with a unique expression of sub-creation within his invented world. Tolkien's Maiar (to which order belong both Sauron and Gandalf), are very powerful - Sauron is responsible for the Ring of Power after all. ${ }^{69}$ Tolkien's creative vision was expansive enough to include other sub-creating beings and sub-creative forms (such as the elves being able to manipulate nature).

\section{Defamiliarising as Lewis's 'supposal'}

Lewis, although he espoused similar 'sub-creating' convictions to those of Tolkien, held to a version of defamiliarisation which manifested as a desire to eschew and avoid assumption to avoid anything, in short, that might only amount to simplistic or representative interpretation, rather than to a provocation to think differently about the familiar, and to experience afresh. Unlike Tolkien, Lewis has no real explicit 'theory' or manifesto of artistic creation or defamiliarisation in so many words (although he has written several essays which touch on the subject of writing). His views may only be gleaned from his writings. In 1961, after the bulk of his fiction had been published, Lewis reflected on the difference between what he called 'receiving' and 'using' art in An Experiment in Criticism. Although the book is more about ways of reading than of creating, ${ }^{70}$ his musings are evidence of his concern as a creator

\footnotetext{
${ }^{69}$ Once a man wrote to him, saying that if Tolkien's sub-creative theology were to hold true, he should rather keep to "the channels the creator [God] is known to have used already" (Tolkien, Letters 188), and that therefore the Dark Lord should not be able to create beings. By this he meant that Tolkien had overstepped in suggesting that evil had the ability to create, or that a divine being would create creatures (such as the Elves) bestowed with a kind of resurrecting immortality. Tolkien replied that sub-creation was at its base "a tribute to the infinity to [God's] potential variety" (188). For this reason there exist "not one but many, indeed potentially innumerable" (188-189) metaphysical channels of creation both known and unknown which are possible, efficacious and acceptable.

${ }^{70}$ Lionel Adey deems this work "a needed corrective to a strain of evaluative criticism that, while encouraging students to form and justify honest opinions, encouraged arrogant, premature, or superficial judgements by those needing to read more widely and with more open minds" (C. S. Lewis: Writer, Dreamer, and Mentor 278).
} 
regarding the perception of art. ${ }^{11}$ Lewis asserts: "[i]deally, we must receive it [the book or story] first and then evaluate it" (92). This is an important point. The receiving is active, not passive. This must not be overlooked: Lewis wanted both receiving and evaluating, but in that order. He goes on: "When we 'receive' it we exert our senses and imagination and various other powers according to a pattern invented by the artist [...] to go through and beyond them to an imagined something which is not itself verbal" (An Experiment in Criticism, 88). It is not for us, says Lewis, to 'use' art, but rather to experience the object, to 'receive' it. This receptive mode lays aside any assumption of meaning, so that the artwork is not viewed as a vehicle for reading any agenda or meaning from the author. Put another way, the defamiliarised story has the potential to be an exploratory space for both author and reader, designed for attentive discovery and bold imagining. Lewis's hope was to facilitate for his readers an imaginative experience that is fundamentally curious as well as creative.

In order to preclude the reader from making assumptions ('using' rather than 'receiving'), defamiliarisation is a useful technique. This defamiliarisation, for Lewis, began with what Lewis has sometimes called 'supposal', inviting his reader to suppose with him. He answered a letter in 1958 inquiring about his methods, in which he explains:

If Aslan represented the immaterial Deity in the same way in which [Bunyan's Giant Despair represents Despair, he would be an allegorical figure. In reality however he is an invention giving an imaginary answer to the question, 'What might Christ become like if there really were a world like Narnia and He chose to be incarnate and die and rise again in that world as He actually has done in ours?' This is not an allegory at all. So in 'Perelandra'. This also works out a supposition.

Allegory and such supposals differ because they mix the real and the unreal in different ways. (Collected Letters 1004)

Lewis's technique is to write in a kind of interrogative mode, and his literary creation is the exploration of a theological question, as he writes in another letter in 1961, after explaining his process of supposing to a different reader,

I asked myself, 'Supposing there really were a world like Narnia, and supposing it had (like our world) gone wrong, and supposing Christ wanted to go into that world and save it (as He did ours) what might have happened?' The stories are my answer. (1244)

What he suggests he is supposing changes across a selection of his letters where he attempts to express the questions he began with. He writes to Francis Anderson in 1963, for example,

\footnotetext{
${ }^{71}$ As has been noted above, Shklovsky was similarly concerned about the perception of art, saying, "The purpose of art, then, is to lead us to a knowledge of a thing through the organ of sight instead of recognition" (6, emphasis added).
} 
The Narnian series is not exactly allegory. I'm not saying 'Let us represent in terms of märchen the actual story of this world.' Rather 'Supposing the Narnian world, let us guess what for the activities of the Second Person or Creator, Redeemer, and Judge might take there.' (1460)

Lewis begins with a sense of uncertainty, questioning the familiar (at least in the Bible tradition), and then projects it into new territory with his supposals. He is experimenting with theology via literature. It is deliberate disrupting of easy definition in order to provoke thoughtful engagement with the text. In other words, he defamiliarises. In May 1954, Lewis wrote of this to a young child who had inquired about what his Narnia books represented. According to Lewis:

You are mistaken when you think that everything in the book 'represents' something in this world. [...] I did not say to myself 'Let us represent Jesus as he really is in our world by a Lion in Narnia': I said 'Let us suppose that there were a land like Narnia and that the Son of God, as He became Man in our world, became a Lion there, and then imagine what would happen. (Letters to Children 44-45)

There are some striking differences between God as man in Jesus, and Aslan, for one thing, as Lewis notes in another letter in 1960. He explains that the Son of God creates the world, and although Aslan's passion and resurrection bears some similarities, it is quite different, not least because the Stone Table is meant to remind one of Moses's tablets, and Aslan comes to resemble the Lamb of the New Testament (Collected Letters 1158). His very phrasing "is meant to remind one" describes the work of defamiliarisation (as supposal) in that the overlapping symbolism and ideas are part of defamiliarisation's design to provoke and evoke associations rather than define them. The very notion of the incarnation, for another thing, is troubled by Lewis's supposal, as God in Narnia becomes not human in a world of humans, but beast. (I shall, however, discuss this particular instance more fully in my third chapter). Like Tolkien, Lewis eschewed the prescription or domination of author-imposed interpretation. Whereas allegory sets out parameters for how things are to be defined, Lewis's supposition defamiliarises by opening up to numerous possibilities.

Although his fiction certainly guides the imagination of the reader, its primary objective is supposal. The author's imaginative supposal is intended to invite the same in the reader. Its very tentativeness as an idea, merely supposing, is part of what makes this a productive experiment in fiction and creation. If imagination is the faculty of meaning making - as Lewis wrote elsewhere, "reason is the natural organ of truth; but imagination is the organ of meaning" ("Bluspels and Flalansferes" 158) - then Lewis seems to suggest that the fresh perspective offered by his narrative might result in the reader's own desire to regard other things with the same renewed appreciation (namely the gospel narrative). His imaginative approach to the 
gospel, through the lens of various fantasy writings, might have the potential to restore wonder (perhaps even belief) in the gospel as a consequence - as if the purpose of questioning is to arrive at the answer he had known all along, but a richer version of it.

The new emphasis given by supposing (and thereby defamiliarising) is to remove the feeling of familiarity, or at the very least to challenge it, thereby encouraging fresh perception, and a readiness to experience first and evaluate later. Lewis's biographer Alister McGrath sums it up like this:

Lewis thus invites his readers to enter into a world of supposals. Suppose God did decide to become incarnate in a world like Narnia. How would this work out? What would it look like? Narnia is a narrative exploration of this theological assumption. Lewis's own exploration of how the figure of Aslan is to be interpreted makes it clear that The Lion, the Witch and the Wardrobe is a supposal - the imaginative exploration of an interesting possibility. [...] Narnia is, so to speak, a theological case study, capable of illuminating our own situation. It provokes thought, rather than answering questions. It demands that we work out the answers for ourselves, rather than accept them predigested. Lewis uses Narnia to show us something without really arguing for it, relying on the power of his imagery and narrative style to allow our imaginations to supplement what reason merely suggests. (278-279)

This supposal method was the way in which Lewis attempted to enter "fully into the opinions, and therefore also the attitudes, feelings and total experience of other men" (Experiment in Criticism 85), and maintain a space that allows the literature to "work on us" (85).

By literally forcing the familiar (Biblical) narratives into new territory, both Tolkien and Lewis have successfully captivated the imaginations of a wide audience. The possible worlds of Middle-earth and Narnia foreground wonder in the way Shklovsky intended defamiliarisation to do, so that those who are familiar with Sunday school teaching and those who are not, are all newcomers - whether it be to Narnia or Númenor - and must explore it together.

\section{Defamiliarising Creators: The Storyteller}

For Walter Benjamin, the story is assimilated into and is produced by the life of its host storyteller, bearing traces of him or her "the way the handprints of the potter cling to the clay vessel" (Illuminations, 92). So it is in all art: the product reveals something about the producer. Storytelling is the mediation between story (or moral) and audience; the storyteller carefully curates the telling. In the same way, creation reveals something about its Creator. Thus, the physical world, for Tolkien, for Lewis (even for Chesterton, as we shall see; it is part of a long- 
standing philosophical tradition) is proof of a Creator. ${ }^{72}$ As Milbank notes in her discussion of Chesterton, "everything is waving madly at us to indicate its divine origin and its storied character. Mediation is therefore not distantiation from God but an enabling of this realization of divine purpose" (11). The chief doctrine implicit in their stories is that the world is divinely created by an independent being, the Creator. Tolkien's and Lewis's invented worlds are the creation of a Creator god, but this is taken as read by both authors - they do not dwell on it. Tolkien and Lewis in their worldbuilding demonstrate a belief in a worldbuilder, or creator, just as artwork assumes the existence of an artist, and story testifies to a storyteller. What makes the creative impulse and creation accounts of Tolkien and Lewis so fascinating is that they blend the theological teleology of creation with an artistic philosophy. At this juncture, as defamiliarisation primarily concerns departures from the original, a brief overview of the account of creation in Genesis provides the blueprint according to which Tolkien and Lewis write their own creation accounts for their worlds.

This blended creative impulse, of artist and of Creator-God, inevitably casts story into the realm of ethics and morality, yet there is good reason to believe that story is an intensely moral or ethical paradigm already. Walter Benjamin notes several fundamentals to story:

The fairy tale, which to this day is the first tutor of children because it was once the first tutor of mankind, secretly lives on in the story. The first true storyteller is, and will continue to be, the teller of fairy tales. Whenever good counsel was at a premium, the fairy tale had it, and where the need was greatest, its aid was nearest. This need was the need created by myth. ("The Storyteller" 102)

From this we may infer that fairy tales naturally reside in both camps of entertainment and ethical discussion. In fact, Benjamin implies that fairy tale, in providing a 'happily ever after', at once creates and resolves a need. Fairy tale is nourishment both in an individual's quest for amusement and for moral counsel. As G. K. Chesterton notes, "people must have conversation, they must have houses, and they must have stories. The simple need for some kind of ideal world in which fictitious persons play an unhampered part is infinitely deeper and older than the rules of good art, and much more important" ("A Defence of Penny Dreadfuls" 77). Chesterton not only highlights a human need for story, ${ }^{73}$ but an aspiration towards and a need

72 Cf. Psalm 19:1-2: "The heavens declare the glory of God; and the firmament sheweth his handywork. Day unto day uttereth speech, and night unto night sheweth knowledge", and Romans 1:20: "For the invisible things of him from the creation of the world are clearly seen, being understood by the things that are made, even his eternal power and Godhead; so that they are without excuse".

73 A point thoroughly explored by Jonathan Gottschall in his book The Storytelling Animal: How Stories Make Us Human (2012), in which he likewise asserts, "Story, and a variety of storylike activities, dominates human life" (Gottschall 29). Brian Boyd's book on Darwinian literary analysis, On the Origin of Stories: Evolution, Cognition, and Fiction (2010), suggests that there is even a cognitive, evolutionary advantage to stories which explains why we 'need' them. 
to conceptualise an ideal world. Chesterton writes that all poems (and indeed all stories) might be thought of in terms of Paradise Lost and Regained ("The Romance of Rhyme" 117). Stories and storytellers arise to answer this need. As fairy tale exists in the realm of ethical discussion, of meeting need and of achieving resolution, it is a perfect medium for discussions of theology, and certainly for discussions of creation.

The storyteller, as the mediator between message and audience, plays an important role in curating the material to best suit the purposes of the message and the expectation of the audience, and this is most evident in narrative tone. Tolkien and Lewis show an awareness of themselves as both narrators of story and mediators of meaning. Many readers have noticed the interesting anachronisms in Tolkien's writing - for example, in a medieval fantasy world, it is quite striking that Gandalf's firework dragon should bear down on the hobbits "like an express train" (The Fellowship of the Ring 28). Gollum's eyes in The Hobbit are also compared to two telescopes, an invention apparently too advanced to appear in any other part of Middle-earth. Other scholars have noted Tolkien's historical appropriation across varying centuries. Shippey, for example, points out small and large anachronisms, from objects such as matches, and fish and chips, to the etymological/historical inaccuracy of using the word 'potato' (instead of 'spud' or 'tater') and 'tobacco' (later changed to 'pipeweed') (J. R. R. Tolkien: Author of the Century loc. 1166). He further notes that in a non-Christian world, Gandalf's use of the word 'heathen' is "illogical" (177). Others have also highlighted further anachronisms, such as umbrellas and waistcoats amongst the hobbits (which were a $17^{\text {th }}$ century invention and rather out of place in feudal Hobbiton environments), or the disparate pre-modern eras of $8^{\text {th }}$ century Anglo-Saxon Rohan juxtaposed against the $13^{\text {th }}$ century Italian mercantile Minas Tirith ("Anachronisms in 'The Hobbit' and 'The Lord of the Rings'”). In his own fantasy world, Tolkien may happily sustain any otherwise incompatible historical settings that he wishes to. On the one hand, this completely flies in the face of Tolkien's found manuscript conceit, for Bilbo (the supposed writer) surely would have no knowledge of trains, express or otherwise, if we assume that the world of Middle-earth is in all other aspects merely a more ancient version of our world. It would seem to be an error on Tolkien's part to include these references - especially when Scull and Hammond declare that for Tolkien "the spell [cast by the sub-creative secondary belief] could be broken by an obtrusive narrator's voice or by a nod or wink or allusion to readers or hearers referring them back to the Primary World" (Scull and Hammond 982). Although I have defined Tolkien's anachronisms as a kind of nod to his audience, I do not believe them to be evidence of his not "[taking] his own work seriously" (982). It is not an inconsistency on a par with Lewis's having Father Christmas visit Narnia, perhaps, though it is noticeable. In employing modern simile, Tolkien may be adopting the narrative style of a custodian or editor, relaying 
information in the most engaging way for modern readers. Shippey seems to believe that anachronisms were "the essential function" at least of The Hobbit (47) and even in The Lord of the Rings: Tolkien seems to use them to bridge "the gap between that time and the reader's modern awareness [...] to guide the reader's reactions, to help the reader feel 'what it would be like' to be there" (loc. 1173). Narrative interruptions are especially apparent, and important, in writing for children, as the differences in narrative voice between The Hobbit and The Lord of the Rings will show. In The Hobbit, both as the first (published) introduction to the world of Middle-earth and of a story that would be marketed to children, the narrator does far more work to acclimatise his reader to the world of the story. I have discussed the opening paragraph above as an example. For Mary R. Bowman, Tolkien appeared as "the editor/translator, not the author, of all the works published under his name. He claims, in essence, that the story was already written, and he is merely transmitting it" ("The Story Was Already Written" 275). Tolkien has chosen to perform the role of archivist in his narration, acting as a guide through the events of a recorded history.

Lewis, on the other hand, has inserted himself far more prominently into the narration of his Narnian chronicles in particular, where he adopts the tone of a benevolent, grandfatherly figure, telling a story to a rapt (possibly younger) child. Lewis makes clear in the Chronicles that he views storytelling as an art in its own right. For instance, in The Horse and His Boy, Lewis demonstrates his respect in the most loving terms when describing Aravis's storytelling:

Aravis immediately began, sitting quite still and using a rather different tone and style from her usual one. For in Calormen, story-telling (whether the stories are true or made up) is a thing you're taught, just as English boys and girls are taught essay-writing. The difference is that people want to hear the stories, whereas I never heard of anyone who wanted to read the essays. (36)

Aravis here exemplifies Lewis's technique. The reverence for story, a good story and well-told, is evident. This extract has the friendly, informal tone that is typical of all the Narnian books. Lewis-as-narrator inserts helpful little parentheses as nods to the child-reader, drawing them in. Another time Lewis writes that Peter's voice "[sounded] tired and pale in the darkness. (I hope you know what I mean by a voice sounding pale.)" (The Lion, the Witch and the Wardrobe 96). ${ }^{74}$ Some critics have found these interpolations to be patronising or condescending, whilst others have appreciated these intrusions as conversational and endearing. Penelope Lively particularly disliked this passage, seeing in it "the cardinal error of condescension towards

\footnotetext{
${ }^{74}$ In fact, Barbara Wall argues that the only feature that distinguishes children's fiction from the rest is the narrative voice very clearly addressing children (Narrator's Voice 2).
} 
children [...], written at rather than for children" ("The Wrath of God" 127). ${ }^{75}$ Contrarily, though he acknowledges that the narrative voice can be "a bully, pushing you into feeling, overwhelming resistance with strong words" (The Child that Books Built 102), Spufford writes with ecstatic enthusiasm about Lewis's narrator:

The author's voice in the Narnia books kindly explained things to the child reading. [...] It was a gorgeously certain voice, which in itself lent a wonderful solidity to Narnia's stars and sausages, so that they blazed in their spheres and swelled in their skins, but it never spoke from a position of adult detachment. There was never even the faintest flicker of a suggestion that Lewis was offering you something you could be expected to like, at your age, though he did not - the voice was as impassioned as you were. It breathed as hard as you did; it felt awe, surprise, fear, joy, and worshipfulness as much as you did. [...] He used the trick of uncondescending explanation, borrowed from E. Nesbit, only to involve you in perceptions you couldn't have had on your own. (101-2)

For Spufford, the voice was enthusiastic, even chatty and excited, not condescending. Wilson, too, finds Lewis's narrative voice reads "[l]ike an enthusiastic guide in a foreign country", one which "is anxious to share with us the unexpected treasures he has found and which we might, without his help, have missed" (loc. 2657). "Part of the pleasure of reading Lewis," he continues, "when it is a pleasure, is meeting with this figure" (2679). Whichever the reader feels, the figure of the storyteller testifies to the strangeness of the content; their voice allows that the story needs 'mediation.' Lewis is telling the story with an imagined audience in mind, so that his narration is both designed for that audience and, in a sense, creates that same audience, just as he creates the story. In other words, the receiver of his narrative, whether imagined audience or actual reader, has a bearing on the way that Lewis tells his tale - his choice of words, or when to intrude into the narrative, and so forth 76 - even though the reader is free to make meaning of the narrative in their own way.

\footnotetext{
75 To this accusation (and that of cliché), Green and Hooper have replied that "it would be surprising if it were not possible to find any to find any such faults in a collection of seven books by a writer, however skilled, who was venturing into an untried field and then using it to produce work which was, as a whole, new and unique in that kind" (C. S. Lewis: A Biography 255). That the two tenets of Lively's 1968 critique, the condescension and her claims of a "cliché-ridden" narrative, are exactly the accusations Green and Hooper tackle in this 1974 biography down to the exact phrasing, shows exactly which critic the biographers had taken on in their commentary.

${ }^{76}$ Even when mediating for a variety of audiences, Lewis is still coloured by his own literary world. It has been said that Lewis's modern reading stopped at Trollope and Tolstoy, and even his biographers Green and Hooper do not scruple to apply Rider Haggard's comment about Andrew Lang to Lewis. That "[w]henever he sets to work to create, his wide knowledge and marvellous memory - and little worth studying in ancient or modern literature has escaped him - prove positive stumbling blocks in his path" (C. S. Lewis: A Biography 251). They were well aware of Lewis's difficulties in attempting to write authentic child characters, particularly their speech, as Green himself had advised him against certain dated expressions and pastimes (242). The natural conversation and behaviour of the children in The Magician's Nephew they put down to the simple fact that Polly and Digory would have been Lewis's childhood contemporaries, "and there is no danger of their talk being out of date" (248).
} 
Perhaps surprisingly, the figure of the storyteller can facilitate the sense of exploration rather than imposition, even in assuming or projecting an audience as Lewis does, by the way he or she invites the readers in and re-imagines the story for new audiences. Other scholars corroborate the idea of a reading which eschews obvious didacticism and instead provokes thought. Maria Tatar, in her introduction to The Cambridge Companion to Fairy Tales (2015), indicates this is particularly true of the ever-mutating genre of fairy tales which

rather than sending messages, teaching morals, or constructing lessons, get conversations going. Piling on one outrage after another, they oblige us to react, to take positions and make judgement, enabling us to work through cultural contradictions using the power of a symbolic story. (3, my emphasis)

In Tatar's estimation, the power of this mode of story (re)telling is its provocativeness, its invitation to ask questions, "to move us to imagine 'what if?' or to wonder 'why?'” (4). Imaginative participation is crucial to emotional and cognitive development.77 This is why both Walter Benjamin (Illuminations, 1973) and Bruno Bettelheim (The Uses of Enchantment, 1976) claim the role of a storyteller is of utmost importance in creating the story for his or her audience - a collaboration which Bettelheim suggests even impacts reading aloud. Bettelheim writes that

the narrator let his unconscious understanding of what the story told be influenced by that of the child. Successive narrators adapted the story according to the questions the child asked, the delight and fear he expressed openly or indicated by the way he snuggled up against the adult. Slavishly sticking to the way a fairy story is printed robs it of much of its value. The telling of the story to a child, to be most effective, has to be an interpersonal event, shaped by those who participate in it. (151)

This is one way in which the adults enter the same space as the child, inviting interruption or contribution to the collaborative storytelling event. Even in reading a pre-written story aloud, this mediator connects the strange new world to the cultural space of the reader (even if for some children this means the telling must be faithfully accurate every time). To meet children in unknown territory, Tolkien and Lewis offer the interpolations of a friendly narrative voice, or mediatory style, in which the story(teller) acts as a mediator between the known and the unfamiliar. A personable voice connects. It is an important device in storytelling which invites the reader into a shared cultural space - and in implying an audience, they have given the audience validity and so too the opportunity to participate.

The kind of shared cultural space being constructed can be seen, for example, in the varying specificity of some of Tolkien's and Lewis's descriptions. The opening line of Lewis's The Magician's Nephew, for instance, specifies a time "long ago when your grandfather was a child"

${ }^{77}$ As has been observed by Paul Harris in his book The Work of the Imagination (2000). 
(9), which is a period which is specific without being specific. When Bilbo in Tolkien's The Hobbit sees trolls for the first time, the reader is told "But they were trolls. Obviously trolls. Even Bilbo, in spite of his sheltered life could see that" (46). Obviously trolls. The pretence that the reader is part of the world of the hobbits is humorous. It may not have been obvious to the readers, but it is now, and it draws them into a world where that conclusion is just as obvious to them, despite Tolkien's sparse description of what makes these beings 'obviously trolls'. The authors only offer enough to go on, but the rest is up to the reader. The White Witch, for example, has 'familiars' among whom are "other creatures" that Lewis "won't describe because if I did the grown-ups would probably not let you read this book" (The Lion, the Witch and the Wardrobe 138). Lewis invites the reader to co-create by an audacious appeal to the individual's imagination. Some descriptions deliberately and predictably stop short of precision. Lewis's descriptions of children's first reactions to the mention of Aslan's name are only emotionally suggestive: while Edmund felt horror, and Peter felt brave and adventurous, "Susan felt as if some delicious strain of music had just floated by her. And Lucy got the feeling you have when you wake up in the morning and realise that it is the beginning of the holidays or the beginning of summer" (65); or later: "that strange feeling - like the first signs of spring, like good news" (74). Lewis is trying very hard to think of situations that will resonate with his child readers: although he does not describe a specific genre of music, for example, each child reader is encouraged to think of his or her own favourite music, and the thrilling feelings which accompany it. It is a gap which his description cannot fill, and so it is the reader's imagination which completes the image being conveyed. Such descriptive devices at once alert the reader to a reality which is different, but without detailing that reality too much, so that the readers do what they can to imagine it for themselves. ${ }^{78}$

\section{Defamiliarising Creation}

When it comes to their treatments of Creation itself, Tolkien and Lewis are principally concerned with the doctrinal function and result (or consequences) of the Genesis creation account and the Fall. That is, even as they defamiliarise Creation and the Fall, they do so within doctrinal parameters. Richard L. Purtill, in J.R.R. Tolkien: Myth, Morality, and Religion (2003), writes that

\footnotetext{
${ }^{78}$ In On the Origins of Stories: Evolution, Cognition, and Fiction (2010), Brian Boyd suggests that this kind of imaginative participation is happening all the time. He writes that as readers we have the "ability to construct a story on meager hints, to fill gaps and infer situations. We take that process for granted" (10). Tolkien and Lewis are drawing attention to it, however, by emphasising the gaps they have made for the reader to fill.
} 
literary myth may embody a truth that is given primary belief: in Tolkien's Silmarillion, the world is created by God, an idea to which Tolkien gave primary belief. But Tolkien or his readers did not accept this idea because of Tolkien's literary myth. Rather, Tolkien wrote the myth, and some readers enjoy the myth, because of previously held beliefs. The belief creates the myth, not the myth the belief. (4)

What Tolkien and Lewis emphasise in their own defamiliarisations thereby highlights the importance they placed on, first, the artistry of creation and, second, the theological significance of the Genesis account. Genesis begins like this:

In the beginning God created the heaven and the earth. And the earth was without form, and void; and darkness was upon the face of the deep. And the Spirit of God moved upon the face of the waters. And God said, Let there be light: and there was light. [...] And the evening and the morning were the first day. (Genesis 1:1-3, 5)

There are several relevant features here. First, there is the creative act by the Creator, and the creation is performed by the act of speech. The existence of earth (if it can be so called, for land and even the sun are only created later) is described only in the abstract, as formless. Even the words 'without form and void' negate any tangible creation as yet. The first thing created, light, is not physical but intangible. The refrain of "morning and evening", repeated at the end of each 'day', establishes the passing of time. The rest of creation follows: beginning with sky, "a firmament in the midst of the waters, and let it divide the waters from the waters" (Genesis 1:6), continuing to seas (1:9-10), vegetation (1:13), celestial bodies including the sun (1:14-19) living creatures (1:20-23), and finally humans (1:24-28). Rounding off each day, the summary refrain is repeated "and God saw that it was good" (see $1: 10 ; 12 ; 18 ; 21 ; 24$ ). Finally, the well-known creation of man from dust fashions humankind as bearing God's image. "Let us make man in our image, after our likeness," God says (1:26). Creation introduces abstract concepts of light and time, and the presence of a deity (or deities) outside of them, and depicts a gradual, cumulative creation exercise.

Tolkien's account of the creation of Middle-earth in The Silmarillion is rather slight in terms of defamiliarisation in comparison to the complexity and uniqueness of his worldbuilding in The Hobbit and The Lord of the Rings: that is, the similarity between his version of creation and the account in Genesis is immediately apparent. Yet the way he defamiliarises demonstrates that his concern is not merely to give his fantasy world the flavour of a Christian creation. Tolkien's concern is not to echo Biblical creation but to reinterpret and transform it in a way that foregrounds the role of the artist. Consider this excerpt from the beginning of The Silmarillion:

There was Eru, the One [...] and he made first the Ainur, the Holy Ones, that were the offspring of his thought, and they were with him before aught else 
was made. And he spoke to them, propounding to them themes of music; and they sang before him, and he was glad. [...] And he showed to them a vision, giving them sight where before was only hearing; and they saw a new World made visible before them, and it was globed amid the Void, and it was sustained therein, but was not of it. And as they looked and wondered this World began to unfold its history, and it seemed to them that it lived and grew. (5-6)

Some of the similarities to the Genesis account hardly need mentioning. There is the preexistent creator being in Eru (or, as he is more commonly known, Ilúvatar ${ }^{79}$ ). The granting of sight in Tolkien's account is a parallel to the creation of light in Genesis, light and sight being mutually inclusive. The 'form' of Tolkien's earth is obscurely described as a world 'globed amid the Void', which echoes the Genesis idea of the earth as "formless and empty, darkness was over the surface of the deep" (Genesis 1:2). Middle-earth's creation is definite, but not yet specific just as in Genesis light was created before the sun. Tolkien's Arda (or Earth) is created in stages, and time passes, and it develops a history. Importantly, as the creative climax, there is a creature made in the likeness of its creator. The Children of Ilúvatar, who "came with the third theme" (7), were another generation of creation distinct from the Ainur, and are Tolkien's version of the image-bearing man. They are described as being loved by the Ainur for "being things other than themselves, strange and free, wherein they saw the mind of Ilúvatar reflected anew, and learned yet a little more of his wisdom, which otherwise would had [sic, ie. have] been hidden even from the Ainur" (7, my emphasis). It harks back to the creation of mankind in the nebulous description of 'made in the image of' (I shall expand this idea further in my third chapter). Both humankind (in Genesis) and the Children of Ilúvatar (in Tolkien) seem to suggest a unique manifestation of the creator in the created. As far as similarities go (and they end there), Tolkien's 'creationisms' seem to accord with the Genesis version significantly. The differences, particularly the references to the music of creation, contribute to a largely different account.

Tolkien's creation account is powerfully musical. As has been seen, Ilúvatar's first communication to his Ainur is to propound themes of music, which they sing back to him. The Ainur are a body of spiritual beings, his embodied thought ('offspring of his thought'), who are delegated the role as agents of creation in their own right. ${ }^{80}$ Tolkien, himself a sub-creator, gives

\footnotetext{
${ }^{79} \mathrm{Eru}$, means the One or Alone. The use of the name meaning the One here possibly has to do with Tolkien's emphasis on Ilúvatar's monotheistic nature - especially when other divine beings participate in the act of creating: he alone was the Creator. Ilúvatar, meaning Father of All, again points to a single origin of all things.

80 This is potentially an allusion to the Trinity. Although the Ainur are generally considered to be the fantastic counterpart to angels, there is a sense of Ilúvatar 'begetting' them rather than creating them (cf. the Nicene Creed, which states Christ was "begotten not made" and "of one substance with the Father"). As agents of creation, moreover, the Ainur seem to express divinity and divine creation in plural form.
} 
sub-creative power to his creations. The Ainur's song is important as the entirety of Middleearth's creation, its beginnings, its disruptions, its movements, are described in musical terms:

Then Ilúvatar said to them: 'Of the theme that I have declared to you, I will now that ye make in harmony together a Great Music. And since I have kindled you with the Flame Imperishable, ye shall show forth your powers in adorning this theme, each with his own thoughts and devices, if he will. But I will sit and hearken, and be glad that through you great beauty has been wakened into song.'

Then the voices of the Ainur, like unto harps and lutes, and pipes and trumpets, and viols and organs, and like unto countless choirs singing with words, began to fashion the theme of Ilúvatar to a great music; and a sound arose of endless interchanging melodies woven in harmony that passed beyond hearing into the depths and into the heights, and the places of the dwelling of Ilúvatar were filled to overflowing, and the music and the echo of the music went into the Void, and it was not void. (The Silmarillion 3-4)

Music is the creating power, and the populating of the earth. It is a musical expression of subcreation: Ilúvatar's music is harmonious yet endlessly varied, as different instruments might be in an orchestral composition, in accord with Tolkien's view of sub-creation as "refracted light [...] splintered from a Single White/ to many hues, and endlessly combined" ("Mythopoeia" 6163). The variation of Genesis creation - light, time, land, sea, animals, etc. - is expressed here as musical variation. Even the Fall is expressed as musical discord: the music which began with "no flaws" is corrupted by Melkor, a kind of fallen angel who begins "to interweave matters of his own imagining that were not in accord with the theme of Ilúvatar [...] and straightway discord arose about him, [...] and their music faltered" (4). ${ }^{81}$ The ease with which Tolkien can communicate the displeasure of discord demonstrates the cleverness of his use of musical terms to defamiliarise creation. Discordant notes are easily imagined, as is the ripple effect of attuning to a false key. The musicality of Tolkien's account defamiliarises the act of word-creation (while being closely related to it), but it also lends creation a theatrical quality, that of an artistic spectacle.

Reimagining Creation in musical terms also appears in Lewis's The Magician's Nephew. ${ }^{82}$ Where Creation in Genesis was characterised by God's words of command or invitation, here

\footnotetext{
81 Tolkien does write a Fall into The Silmarillion, but it is more a "fall of Angels" (Tolkien, Letters 147), which is a different category of Fall to the Fall of men (which "nowhere appears" (147)). It is interesting to note, however, that Tolkien thought all stories required a Fall of some kind: "There cannot be any 'story' without a fall - all stories are ultimately about a fall - at least not for human minds as we know them and have them" (147).

${ }^{82}$ Chronologically, it would seem that Tolkien's iteration of musical creation appears before Lewis's, as there was a manuscript of Ainulidale in the 1930s submitted to Allen and Unwin along with The Hobbit (Scull and Hammond 29-30). Although we cannot be sure, it is likely that Lewis knew of it as this was at the height of the Inklings days, even though The Silmarillion was posthumously published in 1977 and Lewis's The Magician's Nephew was published in 1955. Perhaps Lewis did not think his singing lion so very similar to celestial choir orchestrations.
} 
Lewis's iteration of singing creation 'into being' seems, as in Tolkien's account, to emphasise the artistry inherent in the act of creating. Take for example this scene at the dawning of Narnia, where Lewis describes the world taking shape to the song of Aslan the Lion:

In the darkness something was happening at last. A voice had begun to sing. [...] Sometimes it seemed to come from all directions at once. Sometimes he [Digory] almost thought it was coming out of the earth beneath them. Its lower notes were deep enough to be the voice of the earth herself. There were no words. There was hardly even a tune. But it was, beyond comparison, the most beautiful voice he had ever heard. (95)

The springing, bounding life that is conjured by Aslan's song in creating Narnia, and the harmonic symphony of Tolkien's emerging celestial choir, lend a sense of the artistic to an account that might otherwise be understood as an explanatory tale of command, origin, and causation. Lewis elaborates:

Polly was finding the song more and more interesting because she thought she was beginning to see the connexion between the music and the things that were happening. When a line of dark firs sprang up on a ridge about a hundred yards away she felt that they were connected with a series of deep, prolonged notes which the Lion had sung a second before. And when he burst into a rapid series of lighter notes she was not surprised to see primroses suddenly appearing in every direction. (99)

Lewis makes a very clear connection between the music and what is created as Polly looks on. Were Lewis simply following the Biblical pattern of word-creation (i.e., "'Let there be light' and there was light"), the reader would lose the sense of ethereal beauty that the music gives to the scene. The dimension of music is an interesting defamiliarisation because in this context it suggests a form of artistry and even communal participation and enjoyment. This musical departure is reminiscent of certain Biblical passages describing Heaven, or praise and great transports of emotion, often described in, or at least accompanied by, musical terms and imagery. ${ }^{83}$ In Mere Christianity, Lewis speculates that "Musical instruments are mentioned because for many people [...] music is the thing known in the present life which most strongly suggests ecstasy and infinity" (137). The reader understands the creative act as a form of "symbolical attempt to express the inexpressible" (137): what is evoked in words is expressible by words, but what is felt by music cannot be expressed by words. Herein lies the deliberate defamiliarisation which prevents the reader from automatically receiving the text rather than

\footnotetext{
${ }^{83}$ Many of the Psalms enumerate types of music and musical instruments in their descriptions of worship. Psalm 98, for example, lists singing, rejoicing, clapping, harp and cornet music, and in Psalm 151, trumpets, psaltery, harps, timbrels, dancing, stringed instruments, organs, and loud cymbals. This kind of orchestration is mentioned at times of great rejoicing, such as in 2 Chronicles 5:15 and Revelation 14:3. Music is part of worship.
} 
experiencing it. The evocation of music, inexpressible in words, demands the imaginative participation of the reader to make meaning.

The authors have both defamiliarised, choosing music as the creating expression rather than speech or words. This is a fascinating choice. Both authors would have been aware of a long-standing tradition that connects music and harmony with the created world. The philosophical concept of musica universalis (the Music of the Spheres) has been linked with Christian thought since before the Renaissance and the Age of Reason (James, "The Music of the Spheres" 4). According to this belief, the motion of the heavenly bodies produce sounds which, though inaudible to human ears, are in perfect harmony - Lewis has himself written that "as the dark (though finite) space is not dark, neither is it silent," and that "every planet in his proper sphere" makes "harmony and sound," quoting Henryson's Fables (The Discarded Image 112). Tolkien and Lewis would likely have been familiar with musical compositions, such as Joseph Haydn's oratorio “The Creation," which represented creation musically. While neither Tolkien nor Lewis go as far as to compose actual music, it is interesting that both Tolkien and Lewis would choose to depart from the formula of word-creation, as set out by Genesis, when words were essentially their own area of interest and expertise. After all, both Tolkien and Lewis were not only writers of prose and poetry themselves, but were also exceptionally well-versed in the literature and poetry from many different literary eras, and languages. For writers, this resistance to the comfort of their own medium is astonishing. It may seem rather self-evident, but it is worth noticing the deliberate, defamiliarising disconnect between words describing word-creation (as in "'Let there be light' and there was") and words describing music, which is essentially reading about hearing. Tolkien and Lewis emphasise the gap between the words the reader is reading, and music that the reader must imagine. Although the music-creation is described, it is up to the individual imagination of the reader to bring the imagery and sound to life in his or her own mind.

This choice of defamiliarisation highlights the difference that music makes to a creation account. While both Tolkien and Lewis were evidently influenced and inspired, by the traditional features of the Genesis sequence, their defamiliarisation is evidence of creative reinterpretation - both in the sense of artistic license, and in the sense of a re-interpretation of Creation in Genesis. As Jamie James observes, "Everything you can see and hear and know is an aspect of ultimate truth: the noble simplicity of a geometric theorem, the predictability of the movements of heavenly bodies, the harmonious beauty of a well-proportioned fugue - all are reflections of the essential perfection of the universe" (James 3). Put simply, they have taken the act of Creation as primarily something that is creative, and the musical defamiliarisation of Genesis in both accounts is their attempt to grapple with a theology of creation, and perhaps, of 
creativity. The creative act is presented as something which is akin to music: vast and great and complex and inexpressible in the way that a composition is felt as well as heard. The musical aspect implies artistry in a way that the Genesis account does not. The "fundamental function" of 'sub-creating,' Tolkien writes, is that it is "a tribute to His [God's] potential variety" (Letters 188). An expression of this theology is performed in both creation accounts, and thus both accounts may be understood as a kind of performative theology: Tolkien and Lewis are setting themselves up as mini-gods of their own creation, according to the pattern prescribed by their understanding of divine creativity. The defamiliarisation furthermore positions the reader as defamiliariser and another sub-creator: the reader's own understanding and imagination will shape their own unique idea of this imagery. Just as the Ainur's individual imaginations gave harmony to the music of the creator, so Tolkien and Lewis share some of that creating power with the reader, who does not passively receive, but rather has a part in the creating community.

Because Lewis was concerned with the Creation's function within the context of theology, many of his defamiliarising choices are made within the framework of the theology of the Fall in Genesis 3. While Tolkien's The Silmarillion contains a fall in the discord that enters the perfect harmony of Ilúvatar's creating choir, the fall in the Narnian story, interestingly, does not happen where one would expect. In The Magician's Nephew, there is no equivalent 'In the beginning' at the beginning of the book. It opens instead with Digory and Polly, in London, and the creation scene in Narnia takes place more than half-way through the book, when, through a series of magical adventures, they stumble upon an as-yet-uncreated Narnia at the moment of its creation. Set amongst many other minor defamiliarising details, even the devoted Narnia readers who would have been familiar with Narnia by now, find themselves strangers in this period of Narnian history. And the fall does not occur at the creation of Narnia. Thus, the later scene where Digory and Polly enter Aslan's garden and encounter the magical apple tree and the temptation of the Witch is a red herring. Lewis's version of creation requires a good prior knowledge of the Fall in that he reverses the order: in The Magician's Nephew, the fall occurs in Charn - before the Eden-like scene in Aslan's garden containing the magical apple trees and the temptation by the Witch. Uniquely, Lewis's fall narrative is present, but it is completely removed from the familiar Eden scene. ${ }^{84}$

${ }^{84}$ This discussion of Digory's Fall will be expanded in my third chapter. 


\section{Conclusion}

The reason defamiliarisation in fantasy works so well is that its distance from reality gives creators so much scope for re-imagining and the readers so much more to marvel at. The invented worlds are so fascinating, so numinous, we must view them with fresh eyes. We are so much more ready to wonder at something when it comes to us unexpectedly, from inside the nondescript wardrobe of a stranger's house. Whether what follows is exciting adventure, or just an about-turn back through the wardrobe, the extraordinariness of the fantastic enchants everything it touches: the lamppost in the clearing and the forgotten fur coats inside the wardrobe. The lamppost and the furs cannot be ordinary any longer because they've been touched by another world. Made, in a sense, gods of their own creation by their theology of God as a creative, Tolkien and Lewis derive some aesthetic pleasure in being like God, and even accomplishing a God-given mission. This may not be exactly what Shklovsky had in mind when he proposed the "removal of [an] object from its customary sphere of perception to a new one" (12), yet how well and how naturally these elements correspond with his sentiment. 


\section{Chapter Two: Riddles and Reading Between the Lines}

I say the gods deal very unrightly with us. For they will neither (which would be best of all) go away and leave us to live our own short days to ourselves, nor will they show themselves openly and tell us what they would have us do. For that too would be endurable. But to hint and hover, to draw near us in dreams and oracles, or in a waking vision that vanishes as soon as seen, to be dead silent when we question them and then glide back and whisper (words we cannot understand) in our ears when we most wish to be free of them, and to show to one what they hide from another; what is all this but cat-andmouse play, blindman's buff, and mere jugglery? Why must holy places be dark places? (C. S. Lewis, Till We Have Faces 258-9)

These words of Orual, the narrator of Till We Have Faces (1956), are her indictment against the (pagan) gods: her accusation exposes a concern recurrent in discussion within theology that holy places are dark places, that the divine is intangible and mysterious. The connection between the holy and the obscure is one which is particularly important for this chapter, as the defamiliarisation technique espouses that which is not easily available, but rather requires some effort of interpretation towards understanding or illumination. Defamiliarisation works through riddles, disguises, and masks. In the discussion that follows, defamiliarisation is framed as a quest to make sense of what at first seems elusive by fashioning it into an interpretative challenge. Both defamiliarising technique and theological inquiry require one to puzzle through obscurity to find meaning. In this chapter, the mode of defamiliarisation speaks at once to the conflict between appearance and reality on a fictional, literary level, and the mysteriousness of God on a theological level. It also examines how a spirit of inquiry is promoted by and in the fiction of Tolkien and Lewis.

The themes of seeking out truth and riddling through mystery, so central to the fantasies of Tolkien and Lewis, may also be a narrative embodiment (even homage or mimicry) of the obscurity of certain Biblical scriptures. In the fiction of Tolkien and Lewis, there are ample examples of riddles in the form of paradox: ambiguous characters, narrators, or disguises to be riddled through. The riddling techniques the authors use do not present neatly packaged answers, but rather embrace paradox. Tolkien and Lewis provide a cast of veiled or concealed personalities and unreliable narrators, who evade easy categorisation, ambiguous characters, such as Gollum, Saruman, or Strider/Aragorn, who present puzzles to both Frodo and the reader as they enter the story. It remains uncertain for some time whether they are foul or fair. The physical (and figurative) veiling of Orual in Lewis's Till We Have Faces and the lion-disguise by 
Shift of Puzzle in The Last Battle (1956) work in a similar way: they are presented to the reader as problems needing solving, riddles to be worked through.

The riddle of dual selfhood emerges on a spectrum of 'becoming,' and highlights the doctrine of sanctification, becoming like Christ, which characters such as Aragorn, Gollum, and Orual both embody and simultaneously complicate by remaining somewhat uncategorisable. They eschew easy or explicit meanings. Exploring these dilemmas on a narrative level hints at the need in these works to balance the knowable and the unfathomable. The conflict here is between truth and appearance: both Tolkien and Lewis employ the metaphorical mask, a device that both conceals and reveals. Lewis suggests there is even something transformative about masks, as I shall explain, something akin to the idea of 'putting on Christ' (see Romans 13:14). The theology of sanctification suggests that all creation is in the process of becoming - either in a theomorphic trajectory (e.g. Aragorn) or a degenerative one (e.g. Gollum). While Chapter Three examines Christ archetypes, it is first necessary to establish this point: these characters are fallen 'images' of God; they are not yet, but they are in the process of becoming.

In Chesterton and Tolkien as Theologians, Milbank suggests that paradox and riddle are part of the defamiliarising process because they work against easy or automatic perception. She writes that "the riddle intensifies the contradictions and the mystery and sets it as a deliberate problem, if not a contest" (95-96), which "the reader or listener has to solve" (95) - or perhaps the reader observes the solving of the riddle. The riddle is integral to the modus operandi of Tolkien and Lewis: enigmas, riddles, and paradox represent a search for and amongst hidden things. The defamiliarisation which is designed to refresh our vision is also in this way a kind of concealment: if it refreshes, it does so by requiring the reader to engage in a decoding exercise.

\section{Riddles, Riddling Through, and Reading Between the Lines}

Riddles have a surprisingly poor representation in theological discussion, given that "the reader [of the Bible] is encouraged actually to read the texts under discussion" according to Paul N. Anderson (The Riddles of the Fourth Gospel: An Introduction to John 4, emphasis original). Arthur A. Cohen has mockingly stated that "[t]he difference between theology and literature [...] is that people presume to understand literature. Few bother to understand theology or, bothering, assume that its arcanum is purposely obscure, designed by theologians to warn trespassers off their preserve" ("Myths and Riddles: Some Observations about Literature and 
Theology" 110). ${ }^{85}$ The Oxford English Dictionary defines the verb 'to riddle' as both posing and decoding a riddle ("riddle, v.2"), that is, making and solving the conundrum, complicating and unravelling (which in itself is obviously paradoxical). In this chapter, I mostly confine myself to the latter definition, that of unravelling a mystery. The phrases 'to read a riddle' and 'riddle me this' suggest a kind of decoding exercise; to 'riddle through' is to puzzle out. Northrop Frye also notes that the word 'riddle' has the same root as the word 'read', saying that 'read a riddle' was once practically a verb with a cognate object, like 'tell a tale' or 'sing a song'”' (Spiritus Mundi 124) - an observation which to me suggests the narrative potential of riddle. In the fantasy fiction of Tolkien and Lewis, riddles have explicit and specific uses, but also expanded, metaphorical uses. In other words, riddles are not confined to rhetoric and wordplay, as in the duel of wits between Bilbo and Gollum. Rather, riddle is used more expansively (more than Gollum would perhaps allow), having more to do with subverting or challenging surface-level meanings. Riddling extends to the motif of masks so that disguised characters present a riddle to be solved, even as part of the purpose of adopting a disguise is to keep the riddle unsolved or delay the solution.

Riddle also has a metaphorical connotation, used for anything hidden that needs working out. ${ }^{86}$ It is not a particularly novel technique in fiction, but is fundamental to the themes and concerns of Tolkien and Lewis. Riddles are very connected to the Christian method and message, metaphorically linked with the hiddenness of God, of self-knowledge, or as a metaphor for faith. After all, teaching involves questioning, "re-creat[ing] the subject in the student's mind," as Frye observes: "it is the teacher, rather than the student, who asks most of the questions" (The Great Code xv). "Even the parables of Jesus were [...] fables with a riddling quality" (xv). As Lewis states, "[t]hirst was made for water; inquiry for truth" (The Great Divorce 31). Riddles can exist on a narrative level, as in The Screwtape Letters where Screwtape's account of events are somewhat skewed, and cannot be taken at face value because, as Lewis warns in the preface, "the devil is a liar" (The Screwtape Letters ix). In many cases, the riddle of character is part of the unfolding plot, as with the uncovering of Aragorn's identity. Masks are visual riddles: characters are to be riddled through, in spite of masks or veils, as in Till We Have Faces. The main character, Orual, in fact is the riddle to be decoded. Peter J. Schakel writes that "It is up to the reader gradually to recognize [Orual's] faults and self-deceptions, without a

\footnotetext{
${ }^{85}$ Both Anderson and Cohen move on rather quickly to more specialised discussion: Anderson of riddle specifically in John's Gospel, and Cohen onto some reflections about Jewish tradition - neither of which are particularly relevant to this discussion.

${ }^{86}$ Eleanor Cook, author of Riddles and Enigmas in Literature (2006), would term this kind of extended riddle as an 'enigma' instead, to differentiate it from wordplay (Cook 23). In this chapter, I use 'riddle' because its connotations as a device (in the mask motif, for example) suggest deliberate posing of a conundrum, requiring an answer.
} 
reliable narrator's help" ("Till We Have Faces" 283). Interpretation and decoding are of the essence in the novel (and theology), the key to understanding the connection between the narratives of Part I and Part II. Orual frequently ponders how to read the riddle set before her (see pp. 142-143, 258), and directly invites her reader to do the same (159), suggesting that reading a riddle has something to do with judgement of the truth. For Orual (and for the character Reason in Pilgrim's Regress), this exercise relates specifically to the nature and the existence of the divine. Thus, 'riddling through' not only blocks facile perception, but promotes a mode of inquiry, a method of puzzling out or working through a problem towards an answer or a solution, not dissimilar to a theologian's search for truth. Northrop Frye suggests that riddles are intended to switch on and engage the mind. He writes: "the riddle seems [...] to take us into the actual world [as opposed to the fantastic] explored by sense experience, where the eye is overwhelmingly prominent" (Frye 141, emphasis added). Hence my use of the term 'riddling through' is intended to evoke, through the masking and unmasking of characters, that inquiry into or 'puzzling out' the nature of God and each other. As Lewis wrote in Mere Christianity (1952), "The problem [of faith] is not simple and the answer is not going to be simple either" (42).

To illustrate this, consider this instance in Lewis's The Last Battle, where he demonstrates the danger of failing to 'riddle through' the aptly-named character of Puzzle the donkey. The donkey, who is to play the role of a false god, is himself a puzzle to be puzzled out and part of a con orchestrated by a cunning ape (whose name, Shift, evokes deceit). The mass deception is not particularly complicated: Shift pretends to be the mouthpiece of Aslan, a kind of false priest, bringing out Puzzle (disguised as Aslan, the lion) only occasionally. The old lion skin is not much of a disguise, as it exposes "a good deal of Puzzle's grey nose and face [...] through the open mouth of the lion's head" (15). Lewis makes this point explicitly:

Nobody who had seen a real lion [let alone Aslan himself] would have been taken in for a moment. But if someone who had never seen a lion looked at Puzzle in his lion-skin he just might mistake him for a lion, if he didn't come too close, and if the light was not too good. (15)

Lewis draws the distinction between an undiscerning response (not coming too close nor using bright light) and the kind of seeking and riddling that would have quickly disposed of the false 'lion.' By this point, the Narnians would have had a solid history of the character (if not the personal appearance) of Aslan, and should not have been deceived by the patched, too-long-inthe-neck, too-short-in-the-body, ill-fitting costume. The centaurs who did not read of Aslan's coming in the stars claim this iteration to be a false Aslan - "The stars never lie, but Men and Beasts do" (20). Additionally, if the visual proof of Aslan is ambiguous, the actions of this socalled Aslan are even more so. According to Shift, Aslan "can't be bothered talking to a lot of 
stupid animals" (33); is one with the pagan god Tash (36); seems to intend enslaving the Narnians to their enemies the Calormen (34); rules through fear - "Don't blame me if he swallows you whole or blasts you into a cinder with the mere terror of his eyes" (102); and refuses to be seen or have his subjects "crowding round him and pestering him with questions" (32) - an aloofness Aslan had never before displayed. Even the current Narnian king Tirian, who had never seen either a common lion or Aslan, sees the creature from afar, and denotes a stiffness that seems unnatural. It is this, on top of the worrying reports of his uncharacteristic actions, that causes Tirian to conclude that the creature cannot be Aslan, for proximity to and experience of this hybrid animal show up the farce for what it is.

In Shklovskian terms, I might categorise this as the difference between automated 'recognition' and experience: one might look at Puzzle and 'recognise' him as a lion (as indeed the Narnians began to) - he appears to have a lion's defining features (mane, tail etc.), and he assumes the same authority as Aslan - but experience proves 'recognition' wrong. The folly of relying on recognition is further emphasised by the dwarves who insist on only believing what they can see: "We've been taken in once and now you expect us to be taken in again the next minute. [...] Where's he [the real Aslan]? Who's he? Show him to us!" (71-72). The dwarves are the antithesis of a determination to riddle through. Their resolve not to "let anyone take us in" (141), they are blind to the real Aslan, having "chosen cunning instead of belief" (141). They are as if imprisoned but "only in their own minds [...] and so afraid of being taken in that they cannot be taken out" (141). Lewis demonstrates the problem of not 'riddling through' in the seeing-is-believing mentality embodied by the dwarves: they believed wrongly twice. First, they believed that Puzzle was Aslan when he was not, and then when they saw he was just a donkey, they concluded there was no Aslan, when there was. In contrast, it is Emeth, ${ }^{87}$ a pagan Calormene, who sees rightly, and interprets the signs that Puzzle was "neither Tash nor any other god" (153). Given that all the dwarves (except one) are unredeemed at the end of the story, Lewis emphasises the high stakes of reading the riddle carefully, and proclaims it to be worth the effort it takes. The Aslan farce reminds the reader to consider characters critically for signs of façade, emphasising the rewards of closer scrutiny and interpretation. On a larger scale, the high stakes of invoking an antichrist deception positions Lewis's own story as one which needs careful evaluation too, and so he seems to be inviting that same close scrutiny of the whole tale. If defamiliarisation requires a kind of problem solving, interpretative effort brings

\footnotetext{
${ }^{87}$ The name comes from the Hebrew, meaning 'faithful' or 'true' (Brazier, “C. S. Lewis and Christological Prefigurement" 767). The name Emeth is also interestingly an anagram of the word theme, perhaps indicating the importance of this faithfulness and truth to the story Lewis was trying to tell.
} 
into play the hermeneutic tools for understanding texts, and are particularly suited to the kind of theological inquiry that Lewis (and Tolkien in his turn) invite in their own work.

\section{Divine Mystery}

When defamiliarising texts deal with pretended divinity, they invoke the idea that theology is a mode of inquiry, and that the mystery of God is present but obscure. Tolkien and Lewis mimic the mysteriousness of the divine through their narrative riddling. The meaning is not overt but implicit, as is the invisible God: "[seen] through a glass, darkly" (1 Corinthians 13:12). Christian theologians are well-versed in the idea of a mysterious deity. Traditionally, the doctrine of God's transcendence has been understood to mean that whatever may be said about God can only be said analogically. Lewis has written on this in his sermon "Transposition" (1949), in which he summarises the teaching of Thomas Aquinas to the effect that what is holy requires metaphors and imagery - linguistic forms which depart from the literal and matter-offact - precisely because language is insufficient. ${ }^{88}$ The ability or inability of finite creatures to adequately describe an infinite God has always been a topic of theological discussion. Some believe that, as God is unknowable, all that can be said of him with any certainty is what he is not. Hiddenness, obscurity, and absence have long been associated with the mysteriousness of the divine.

In On Christian Theology (2000), Archbishop Rowan Williams argues that it is precisely in this unarticulated territory that God can be found. He writes that the gospel narrative predominantly features "an image of the failure of images, which is also an absence that confirms the reality of a creative liberty, an agency not sealed and closed, but still obstinately engaged with material environment and an historical process" (195-96). In other words, images and imagery in the Bible both describe and fail to describe. To use an image is also to note the 'failure of the imagery' - in part because it is 'only' figurative and in part because language itself fails. It can only evoke or suggest; it cannot be the thing it evokes or suggests. In the same way, theology does not expect to supplant Scripture or even to adequately describe it. The mysterious is not meant to be explained away entirely. Readers are invited into creative liberty and involvement, to riddle through the obscurity - of the extra-Scriptural text, Scripture, and the divine itself - but not with the expectation that all will necessarily be made clear. Williams's point is echoed by Maxine E. Walker:

\footnotetext{
${ }^{88}$ In this sermon, "Transposition", as with much of his broadcasting and theological writing, Lewis was simplifying and popularising the well-established ideas (though unresolved in some senses) of the Cloud of Unknowing and the Pseudo-Dionysus tradition, and the ideas of great philosophers, such as Plato and Aquinas, for a non-specialist audience.
} 
Recalling the Old Testament cherubim that border the ark and the God who is present between them but not bodily there, Williams says this gap between the images is where God would be if he were anywhere. The God of Judah and Jesus are seen by looking into the gap between the holy images. ("How Do You Read It?" 210)

It is as if the image draws attention to what it is, and equally what it is not - much like the ark of the covenant is an expression of God's presence, ${ }^{89}$ but is not to be taken as God's Presence itself. Extrapolating from this, one can understand that defamiliarisation in Tolkienian and Lewisian writing acts in the same way: it images forth a representation (even an interpretation) of God which is simultaneously very much not God, or at least not meant to be taken as simply as that. ${ }^{90}$ Defamiliarisation is provocative in this context, intending to draw attention to the limitations of its rendering. What Walker and Williams have suggested here is a riddle of presence-in-absence, of clarity-in-obscurity, ${ }^{91}$ that is necessary to understand doctrines concerning a mysterious God. Walker agrees with Rowan Williams that these doctrines resist closure (210). As Walker sees it, the image is not the focus but points to that which is beyond it. Likewise, representative images of God - whether holy images of cherubim on the Ark of the Covenant, or Aslan in Lewis's Narnia books, or Christ types in Tolkien's fiction - draw attention to the absences (or riddles) which imply presence. Because the images fail, as Williams writes, obscurity directs attention to where the image falls short. This is why it is important to motivate readers to become active interpreters of such riddles, both in theology proper and in theological fiction.

The inevitable unattainability or 'beyondness' in expression when dealing with the divine is not quite symbolism either. This inexpressibility suggests the significance not only of acknowledging gaps or riddles, but exploring and imagining into them. In her essay "Theology," contemporary American novelist and theologian Marilynne Robinson suggests that the role of scriptural language is more of an indication to look beyond than to look at:

Religions are expressions of the sound human intuition that there is something beyond being as we experience it in this life. What is often described as a sense of the transcendent might in some cases be the intuition of the actual. So the religions are quite right to conceptualize it in terms that exceed the language of common sense. [...] But the unfathomable has a most legitimate place in any conceptualization of an ultimate reality. (212, emphasis added)

The gist of these speculations is quite simple: because Biblical scripture itself works to describe the divine in language of "beauty and subtlety and power" (212), to suggest experience that does not easily translate to words, literary works dealing with these mysteries cannot deal with

\footnotetext{
${ }^{89}$ See also other symbols of presence in Exodus: the tabernacle, the pillar of cloud and fire.

${ }_{90}$ As I shall discuss in further detail in my third chapter with regard to Christ archetypes.

91 Not to be confused with chiaroscuro, emphasising the contrast between light and dark in visual art.
} 
them explicitly either. This is not to say that either scripture or religious fantasy only ever deals in the unfathomable, but both must accept a certain intangibility. Readers of Biblical scripture and of Christian fiction are required to make sense of an idea which is only partially representable or communicable through text.

There is a Biblical precedent for divine mystery and the assumption that knowledge, even partial, must be sought out. Proverbs 25:2 suggests, "[i]t is the glory of God to conceal a thing: but the honour of kings is to search out a matter." In the epistle to the Corinthians, Paul declares:

For we know in part, and we prophesy in part. But when that which is perfect is come, then that which is in part shall be done away. [...] For now we see through a glass, darkly; but then face to face: now I know in part; but then shall I know even as also I am known. (2 Corinthians 13:9-12, emphasis added)

Paul talks here about a kind of spiritual 'seeing' as a paradox that contains both knowing and unknowability: seeing, but seeing imperfectly. This idea is paraphrased by Northrop Frye in Spiritus Mundi: "we see now in a riddle in a mirror, but we solve the riddle by coming out of the mirror, into the world that words and things reflect" (147). Partial knowledge ('through a glass, darkly'), even extra-Biblical testimonies as Frye suggests, will eventually give way to knowing fully and being fully known ('face to face'). Until then, knowledge of the divine is possible, but ultimately partial, mysterious, and unfathomable. Lewis has written that "[t]heology is, in a sense, an experimental science" (Mere Christianity 164). This, then, is why theology can be and has been described as a mode of inquiry. The hiddenness of things is what invites the inquiry. In an interview with Sarah Fay, Marilynne Robinson observes that "Religion is a framing mechanism. It is a language of orientation that presents itself as a series of questions" ("The Art of Fiction" no. 198). Ricoeur suggests that "the questions 'who?' 'what?' 'why?' and so on" invoke a chain of responses "that is none other than the story chain" (Oneself as Another 146).

According to Ricoeur, the answers to all questions are never simple, but storied. If religion is a series of questions, it follows that what emerges as an answer to those questions is narrative in form. In fact, Wilson speculates that

The corollary of [Lewis's] great 'mythopoeia' discussion with Dyson and Tolkien was that the story of Christ was much more important than any doctrine which a fallible or fallen human mind could extract from it. Trying to define, or speaking as if it were possible to define 'precisely what He meant' by saying who He was, was a sort of profanity. (loc. 3035)

Narrative, especially fantasy narrative, is thus presented as a viable paradigm for spooling out scenarios in which answers to questions, theological or otherwise, might be conceptualised. For Milbank, this method is taking "readers deep into the darkness and duality of the paradoxical, 
and the inability of the world to save itself" (Chesterton and Tolkien 113). Difficulty is necessary to prompt a search for meaning, an interpretative drive to make sense of the riddle. Milbank writes that putting contradictions together "leads to a moment of recognition beyond the contradictions in which a truth becomes manifest [...] as complex or different from what we originally assumed, and yet illumined" (88). Concealment and mystery create a need to riddle through the mystery, see through the obscurity, to read through absence to presence.

\section{Concealed Identity}

Tolkien has employed both profound theological and more playful riddles in his books. One of the more playful occurs in The Two Towers, where he causes Aragorn, Gimli, and Legolas to confuse Gandalf with Saruman, who is known to wander Fangorn Forest. During their pursuit of kidnapped hobbits Merry and Pippin, the trio are cautioned by the Rohirrim patrol that Saruman has been seen lurking in those parts. They are warned that "he is a wizard both cunning and dwimmer-crafty [that is, skilled in the craft of magic], having many guises. He walks here and there, they say, as an old man hooded and cloaked, very like to Gandalf" (437). This description does not seem to evoke Gandalf, excepting advanced years and a cloak; the reader first saw Gandalf driving his little cart through the Shire in broad daylight, with a pointed blue hat, a long grey cloak, a silver scarf, a long beard, and bushy eyebrows (The Fellowship of the Ring 25). Even though an old man in grey may indeed be similar to Gandalf, at this point in the story the reader believes Gandalf to be dead. There is something justifiably eerie, therefore, about the figure who appears noiselessly at the edge of the firelight one night: "an old bent man, leaning on a staff, and wrapped in a great cloak; his wide-brimmed hat [...] pulled down over his eyes" (442), and who vanishes without a trace at the same time the horses do. When Aragorn, Gimli and Legolas later see an "old man" in "dirty grey rags" with a "bent figure" who was "walking wearily, leaning on a rough staff" (492), they had good reason to be on their guard. They "could not see his face: he was hooded, and above the hood he wore a wide-brimmed hat, so that all his features were overshadowed," but the figure seemed to be able to throw off his weariness, springing "nimbly as a goat" up the rocks to where they were (493). Beneath the grey rags, he seems to be clad "all in white" (494), Saruman's colour, and he seems to hold them in thrall, so that only when he turns away do they stir "as if a spell had been removed" (494). It emerges that the first lurking figure at the fireside was indeed Saruman, but the hooded and cloaked man they later see is Gandalf. ${ }^{92}$ This scene serves to illustrate how Tolkien deliberately seeks to confound appearance-based judgements or easy recognition. His story recalls the

${ }^{92}$ In the following chapter, this quasi-assumption of Saruman's role will be discussed in further detail. 
disciples' Emmaus road encounter with Jesus, who appears and talks with them, and they do not recognise him, though they later recalled, "Did not our heart burn within us, while he talked with us" (Luke 24:32). Tolkien seems to suggest that things may be more than they appear, and that inquiry into hiddenness is to be encouraged and will be rewarded.

As already mentioned, a key example of a paradoxical, dual self in Tolkien's work is the character of Gollum. Gollum is an example of Tolkien holding two extremes in tension, without ever quite resolving the difference. Quite apart from the apparent schizophrenia Gollum displays in his talking to himself (and also answering himself), Gollum's paradox is in his very personhood. Gollum's 'humanity' (if properly so-called for a hobbit-like creature) has slowly drained away, to the point that he barely resembles what he once was. Though once something not too dissimilar from a hobbit, Gollum is barely recognisable: called "a wretched gangrel creature" (The Two Towers 657), he looks "like a spider himself, or perhaps more like a halfstarved frog" (738). The reader knows, as do many of the characters, that this change is due to the prolonged (and willing) exposure to the Ring and its influence. Milbank has characterised this transformation of Sméagol to Gollum as "a person rendered grotesque by his loss of virtue and fall into unbeing" (72). What she describes is not so much a transmutation of one thing into another, but a gradual unbecoming, an unravelling of being itself. If indeed the absences and failures of an image are just as important as the image itself, then what Gollum is not is just as important as what he is. For this reason, the loss of divinely created purpose and form is a tragic departure from self. Gollum's duality expresses Tolkien's "privileging of form itself as a positive thing" (Milbank 74) because he could conceive of no fate more despairing than that departure from being. This self-talking, obsessive, gangrel Gollum figure is nothing like a noble creation. Tolkien does not explicitly meditate on this paradox. The comparison exists only in the mind of the reader as they riddle through the enigma of Gollum's dual selves. It is as if Tolkien is drawing the focus to the erstwhile identity he once possessed as Sméagol, by characterising him as no more than the involuntary, retching sound he makes - "gollum."

This name discrepancy, moreover, raises more questions than it answers. Gollum's new name does contain some part of the old, as if this sound is some lost echo of that former self, and it raises the question as to whether that identity is now wholly lost. Was this name given deliberately to replace the Sméagol that was, as a recognition of his departure from that identity? Or, having been chased out from his home and without anyone to testify to the identity of Sméagol, was he assigned the name because he no longer bore any resemblance to a known species by which he could be identified? However the reader answers these questions, the mere fact of renaming reinforces an already irreconcilable difference between the two identities. Just as his form is a paradox, Gollum's name both conceals and identifies. On the one hand the name 
Gollum conjures exactly - its harsh, ignoble sound evokes no heroic character - however, it conceals the complete, erstwhile self, untouched by the corrupting influence of the Ring. Even the reader knows him first as Gollum, and Sméagol is only a rumoured past in the second chapter of the first book. Gollum is a paradox of fissured selfhood, the appearance giving little indication of an underlying reality.

In the case of Aragorn, the metaphor of hidden identity is actually performed - and not only because it transpires that he is the incognito heir to the throne of Gondor, but even more simply because his first appearance is as a man who is hiding: Aragorn is literally hooded. As Mary R. Bowman puts it, "Tolkien does much to exploit that distance between reader and character. At the same time, he often works against it, shaping a reader's experience so that it is as much as possible like that of the characters" ("The Story Was Already Written" 281). Tolkien embodies the search for truth particularly through the interactions of his characters as they meet and evaluate each other, as the hobbits do on first meeting Aragorn as a mysterious stranger in Barliman Butterbur's inn at Bree:

Suddenly Frodo noticed that a strange-looking weather-beaten man, sitting in the shadows near the wall, was also listening intently [...], smoking a longstemmed pipe curiously carved. [...] A travel-stained cloak of heavy darkgreen cloth was drawn close about him, and in spite of the heat of the room he wore a hood that overshadowed his face; but the gleam of his eyes could be seen as he watched the hobbits. (The Fellowship of the Ring 156)

This first impression of Aragorn gives the reader and the hobbits ample cause to be suspicious of him (even though it turns out that he is trustworthy). He is also closely watching the hobbits who are trying to be inconspicuous. Butterbur says little more than that the man is one of the Rangers, often in a hurry, quite secretive and unpredictable in his wanderings, and that he is known as Strider, though it is thought not to be his proper name. When later known to the hobbits, Aragorn himself even makes a joke about Butterbur's suspicion of "mysterious vagabonds of my sort" (164), and wryly describes his own appearance as having "rather a rascally look" (164). This is reminiscent of the Biblical proverb, "Charm is deceptive, and beauty is fleeting" (Proverbs 31:30), and in this scene Tolkien embodies that verse, and makes it his own, as Aragorn himself confirms: "I look foul and feel fair. Is that it? All that is gold does not glitter" (The Fellowship of the Ring 171). ${ }^{93}$ Pippin sagely replies that "handsome is as handsome does [...] and I daresay we shall all look much the same after lying for days in hedges and ditches" (171). While Pippin's comment mocks hobbit-ish dandyism, it nevertheless shows an inkling that things are not always as they seem. Aragorn is a self-confessed "hunted man" (170),

\footnotetext{
${ }^{93}$ It is interesting to note that this is a defamiliarised phrase, a Tolkienian reversal of the proverbial phrase that 'all that glitters is not gold' - used in Shakespeare's Merchant of Venice (2.7.69), but also appearing in Chaucer's 'The House of Fame' as "Hit is not al gold, that glareth" (Book I, 272).
} 
and he admits rather grimly that "[his] looks are against him" (170). His appearance both conceals and reveals: his true identity as royalty is effectively concealed by his vagabond exterior, but that very guise draws attention from those who find his kind suspicious, and sets him apart from the crowd in which he might want to go unnoticed. Aragorn's appearance gives only part of the story, and again, what his mask conceals is almost as important as what it seems to imply or reveal.

Aragorn's physical concealment in this first meeting may be read simultaneously as metaphorical concealment. Even the name 'Strider' is assigned to him, acting as a veil, or mask (it is not surprising to the reader when Gandalf reveals in a letter to Frodo that his true name is not Strider). Even so, the name 'Aragorn' means nothing to the hobbits or the reader when they first learn it; his destiny is heralded by several of his other names, learned later: Elessar, or Elfstone which speaks of his kingship in Gondor. ${ }^{94}$ 'Aragorn' does not allude to his lineage and future kingship, nor to his identity as the Ranger Strider. Butterbur's doubts about Aragorn, despite Gandalf's vouching for him, are not undeserved.

Despite the aspersions cast on his character, Aragorn complicates the issue by expressing his own suspicions of the hobbits, as he had been unconvinced initially about their identities. "I did not intend to tell you all about myself at once," he tells the hobbits; "I had to study you first, and make sure of you. The Enemy has set traps for me before now" (170). 95 The net of suspicion is crossing over itself, and that is just the point: the truth of the matter is not always clear. It points to a general theme of pitting the appearance of something against the reality - as Frodo himself observes to his fellows on first meeting Aragorn, "I think one of [the Enemy's] spies would - well, seem fairer and feel fouler, if you understand" (171). In other words, although the 'good' and 'evil' characters fairly quickly resolve into their various moulds, Tolkien deliberately troubles the first impressions the characters have of one another to teach the reader early on that they will need to develop their own faculties of discernment to uncover truth in the story - "pushing readers to evaluate characters as the author does" (Bowman, 283).

\footnotetext{
${ }^{94}$ From the Prologue, we know that Elessar is the name of the King who commissioned copies of the Lord of the Rings saga supposedly penned by Bilbo and Frodo, but it is not a name associated with Aragorn until a good way into the actual quest. At the council of Elrond, he is first identified as a descendent of Isildur, an erstwhile king of Gondor, which implies his claim to the throne. In Lórien he is named "Elessar, the Elfstone of the House of Elendil" (375), and even then there is little premonition that this (and not Aragorn) will be his name as King of Gondor. Having taken up the name at that point, a later declaration that the king Isildur is one of his ancestors, and he is "heir of Elendil" (393) suggests his claim to the throne, before he finally comes into his own as king in the final book. As Treebeard says, "Real names tell you the story of the things they belong to" (465).

${ }^{95}$ Unfortunately for Aragorn, his warning about strangers is turned immediately on him. His "lesson in caution [is] well learned" (165), conditioning the hobbits to be suspicious of appearances thereafter, a suspicion that includes him for a short while. Frodo's wariness of characters such as Boromir, and Sam's wariness of Gollum, ultimately protect them, however.
} 
Boromir's desire for the Ring (and therefore potential for corruption), for example, is signalled fairly early on through his contributions at the Council of Elrond. Though the reader is not misled in any serious or lengthy way, Tolkien intends to force readers into a kind of critical thinking which will be necessary all the way through the book, and which even then may not completely resolve into easy answers: is Gollum truly evil or good deep down (he does accomplish the quest)? What about Wormtongue, under the influence of Saruman who poisons the mind of Théoden, but who eventually kills Saruman? Aragorn's verse, "all that is gold does not glitter," suggests that what is valuable or true is not always immediately apparent, but is worth the work it takes to search it out.

Milbank has speculated that the duality of self, represented in Gollum, Aragorn, and others, is significant for the fate of Middle-earth. She points out that

[i]t will only be characters who achieve a sometimes grotesque duality of selfhood who will be able to turn the fortunes of Middle-earth, whereas someone with the unfallen unselfconscious unitary personhood of Tom Bombadil cannot. These fissured selves come to embody a sort of paradoxical truth. (Chesterton and Tolkien as Theologians 99)

The paradoxical truth she refers to may be seen in the example of Frodo, who will take the Ring to Mordor but does not know the way, whose "Christological character" is also "un-Christlike" being in "sinful thrall to the Ring he bears" (99). Milbank alludes to what seems to be Tolkien's expression of the fallenness of humankind. ${ }^{96}$ David Lyle Jeffrey, writing on "Tolkien as a Philologist", has suggested that The Lord of the Rings is "a work of art that develops an acute sense of fallenness" wherein "the universe is, if diminished, not totally corrupted" (67). Milbank's assessment of Tolkien's use of fissured or dual selves speaks to a conception of humankind as the image of God, but fallen. In other words, the image of God in fallen man is now corrupted and partial. Tolkien still displays hope for the fallen creature. Some sense of redemption is still possible: Gollum is, for instance, the one to destroy the Ring in the end, and Frodo is ultimately faithful in his mission despite his struggle against temptation. It seems clear that Tolkien's emphasis on ambiguous, dual characters is designed to acknowledge the fallenness or corruption of God's image in humanity.

\section{Hiddenness as Mask and Veil}

The hiddenness of God is traditionally conceptualised to be a result of the Fall; before the Fall, Adam conversed and walked with God. Ignorance in general is thus conceptualised as one of the consequences of original sin, and it extends to ignorance of God. The provocative

96 The Adam archetype is a discussion I shall take up in more detail in the next chapter. 
ambiguity of characters, used to allude to the hiddenness or veiled aspect of God, may therefore also act as a projection of humanity's deficiencies: God appears to be hidden or mysterious because humanity is itself veiled (or blindfolded). So, perhaps, humanity's failure to see God is due to its lack of self-knowledge. Lewis has embodied this idea fairly literally in his novel Till We Have Faces, in which the protagonist Orual is physically veiled for most of the story. In this context, it is easy to see how the unmasking impulse might be a metaphor for faith. The unknowable God is something of a riddle to be solved, questioned, explored, just as a mysterious character must eventually be unmasked. ${ }^{97}$ The process of unmasking, or making visible, is a significant motif for revealing either the truth or the fraud which lies beneath.

It must be noted, along the lines of Rowan Williams's presence-in-absence premise, that masks somewhat paradoxically suggest presence, even as they conceal. Joseph Campbell has written extensively on the role of the mask in the 'primitive' world and its potential for suggesting and embodying mythological beings. In Primitive Mythology: The Masks of God (1959), Campbell notes that the mask is simultaneously a representation, or image, of a supernatural being, as well as its embodiment: it is "revered and experienced as a veritable apparition of the mythical being it represents - even though everyone knows that a man made the mask and that a man is wearing it" (21). Another way that deities are similarly manifest, both represented and embodied, is in imaginative art and literature, such as these theological fantasies. Their representations of the supernatural are suggestive rather than concrete, and can nevertheless be experienced as embodiments of the real thing. This is, on one level, fiction as a mask (or image) of God. ${ }^{98}$ Fictional representations of God give him a face, like Campbell's masks, to respond to and interact with. In his fiction, it is this riddle of absence-in-presence that Lewis seems to be grappling with. Part of the exploration into the hiddenness of God for Lewis is done through a recurrent motif of mask or disguise - already demonstrated (negatively) with Shift and Puzzle - but nowhere is it more apparent than in his novel Till We Have Faces.

Lewis's retelling of the Cupid and Psyche myth, narrated by Orual, tells the story of her younger sister Psyche, who was sacrificed to the son of Ungit, ${ }^{99}$ the God of the Mountain, ${ }^{100}$ in a

\footnotetext{
${ }^{97} \mathrm{Cf}$. Anselm's concept of "fides quaerens intellectum", faith seeking understanding.

${ }^{98} \mathrm{After}$ all, Christ's incarnation is described as "the image of the invisible God" (Colossians 1:15).

${ }^{99}$ Names seem to be significant here. Orual ("rue-all"? the sceptical Everyman) is also called Maia, meaning "mother and nurse-goddess" (Adey, C. S. Lewis: Writer, Dreamer, and Mentor 158), (cf. "Mara" meaning bitter in Ruth 1:20-21) by her sister Psyche. The name Maia seems to foretell Orual's eventual unity with the gods at the end of the book. Ungit (despite being a version of famously beautiful Aphrodite) has been given an ugly name to validate Orual's dislike, and this name contributes to the reader's revulsion at her.

${ }^{100}$ Lewis may be grappling with other 'pagan' religions in this book and exploring to what extent they contain truth. There are some interesting parallels between this and The Last Battle, published in the same year, which features a Calormene pagan being taken into heaven with the true Narnians. In some
} 
bid to save their country from calamity. Orual is incensed not only that Psyche consents to this but, moreover, that she continues to love and follow the God of the Mountain when she survives the sacrifice. Orual believes that the gods "deal very unrightly" with humans (258), never revealing themselves and thereby dooming mortals to guesswork and capricious punishment. The gods "torment men with glimpses" (253), "unveil[ing] to one what they hide from another" (253). In Orual's complaint, Lewis represents a common objection of the unbeliever, and explores this objection through Orual's journey. He does this through the motif of masks and veils, and knowing God comes to be synonymous with face-to-face encounter. Essentially, Orual accuses the gods of this hiddenness or facelessness. She comes to realise, however, that her jaded view of the gods is more due to her own limitation, her own facelessness, her own inability to see rightly. Most of the novel is taken up with Orual's complaint against the gods, telling her story to testify to their misdeeds in Part I, but in Part II Orual takes up her pen again to set the story straight, implying that even her testimony had been concealing something. "Since I cannot mend the book," she writes, "I must add to it. To leave it as it was would be to die perjured" (263). Till We Have Faces presents the reader with a complex veiling of character, a veiling which does not only conceal her from her fictional peers by means of a physical veil, but also from the reader by means of an unreliable first-person narrative. Thus, the riddle of what may be hidden behind a mask applies to the entirety of Orual's narrative, which is masked from the reader for most of the book. The novel takes its title from a line near the end of the book, where Orual writes "I saw well why the gods do not speak to us openly, nor let us answer. Till that word can be dug out of us, why should they hear the babble that we think we mean? How can they meet us face to face till we have faces?" (305). Orual's veil is not only physical but spiritual, and the metaphorical face she describes points to the idea that faces are the site of encounter. Her complaint against the gods, which served as the epigraph for this chapter, is part of the mask she wears for most of her narrative, concealing part of the story from the reader and even from herself. Meaningful encounter, she suggests, can occur only when the face is revealed.

ways, Lewis has represented the reverse-image of the Christian idea: the talk of being devoured by the God of the Mountain is a strange and primitive depiction of the Christian idea of 'being one with' God (see 1 Corinthians 6:17). In From Achilles to Christ: Why Christians Should Read the Pagan Classics (2007), Louis Markos summarises the view that Lewis seems to hold. Markos explains that those who advocate Christianity as the only complete truth also believe that "other philosophies, religions and cultures have hit on certain aspects of the truth. [...] leap[ing] past their human limitations and catch[ing] a glimpse of the true glory of the triune God" (12). He goes on to say that these 'pagan' texts are "proto-Christian works of almost prophetic power that point the way to Christ and glimmer with a faint but true light" (23). Lewis does not seem to invite his readers to distinguish what is pagan and what is not, but rather asks what glimpses of 'the true glory of the triune God' are evident in his unchristian world. 
The mask/veil motif in Orual's story contributes to the theme of concealment which Lewis uses on a micro and macro level throughout the narrative. The proliferation of mask and veil motifs throughout the text has already conditioned the reader to expect that the truth is veiled. The masks and veils come in several forms, including literal masks and veils over the characters, and figurative masks and veils over the narrative. The servants of the deity Ungit wear wigs and painted faces which have the effect of looking "like wooden masks" (50). Veils are thereby associated with a kind of holiness (or at least servitude) that requires selfeffacement almost to the point of being de-humanising. On the other hand, some masks, like Orual's, conceal a flaw or weakness. When Orual is cast to be part of a welcoming performance for her new stepmother, the King her father orders veils saying, "Do you think I want my queen frightened out of her senses? Veils of course. And good thick veils too" (19). Orual observes, "I think that was the first time I clearly understood that I was ugly" (19). She is nicknamed "curdface" (27) and "goblin daughter" (33). The nickname is a cruel truth telling, itself a kind of unveiling even as she veils herself. There are also the veils worn by the court both on special occasions and to disguise what is displeasing. Veils conceal. Occasionally Orual slips out of the castle in a veil so that she can pass unrecognised. Veils hide vulnerability. The new queen, when she arrives, is also veiled, not to disguise her ugliness, but her terror and weakness. Orual also notes tactical advantages in concealing her face, hiding a lack of reverence before the Second Priest of Ungit, and undiplomatic emotion (such as fear) when she negotiates with neighbouring nations as queen. Her veil gives her an advantage, allowing her to conceal information. When she returns after seeing Psyche, for example, Lionel Adey points out, "she omits to mention her brief glimpse of the palace and [her] emotional blackmail of Psyche" so that "the resumed veil hides her possessiveness, which destroys the beloved" (C. S. Lewis: Writer, Dreamer, and Mentor 158). Veils and masks set apart their wearers (such as the servants of Ungit), disguise, and hide ugliness or emotion - but all these iterations of masking are also associated with an obstacle to truthful encounter, or a barrier to relationship between characters.

In his 1991 philosophical work Entre Nous: On Thinking-of-the-Other, Emmanuel Levinas describes the face as a site of recognition and of appeal, the place of "extreme exposure, defencelessness and vulnerability itself" (45). For Levinas, the face is the point of encounter with the other: he writes that "it is as a neighbour that man is accessible: as a face. [...] the relationship with a being is an invocation of a face and already speech, a relation with a depth rather than with a horizon" (9-10). That is, there can be no true relationship with something that is without a face. ${ }^{101}$ As Adey puts it, "Orual realizes that [the gods] can reveal themselves

${ }^{101}$ For this reason, I use the words masks and veils almost interchangeably as both similarly contribute to this idea of facelessness which is a unifying theme throughout Lewis's novel (the original title was 
only to mortals with 'faces' [...], that is, with developed and complete identities, able to face themselves as they are and have been" (153). Facelessness, whether due to masking or veiling, is therefore associated with isolation, lack of self-knowledge, guardedness - all things which Orual must shed in her journey - and represents an obstacle to truth, whether it be divine revelation or self-knowledge. Orual's own limited perception, her own facelessness, is an obstacle to true encounter with the divine, and thus facelessness becomes synonymous with faithlessness.

Orual sets herself up almost as a veiled deity by choosing to take up the veil permanently. She does this when her beloved sister Psyche is lost to the God of the mountain: it is no accident that the metaphorical significance of being faceless (and therefore incapable of true encounter) occurs when Orual cuts off the only meaningful relationship she had in her life, separating herself from relationship and recognition. Only at the end of the novel, for example, does she discover what Adey calls her "guilt in using Psyche and Bardia as objects of possessive love" (154). The core of her complaint against the gods is their unknowability, yet this is exactly the advantage she most enjoys in her permanent veiling. She remains unmoved before the King, who used to terrify her, and refuses to remove her veil at his command. She observes that " $[t] o$ see his face while he could not see mine seemed to give me a kind of power" (190). Orual finds herself fearless even in the face of "some sudden stroke of the gods [which she believed] would fall on [her] very soon" (191-192). The permanent veiling might be a kind of resignation, not simply to her ugliness but to her lot in life; she sees herself at the mercy of greater powers - yet she counts her veil as her greatest and most powerful asset in ruling later as queen. She notices that her veiling results in others discovering "all manner of beauties in [her] voice" (237), while they speculate about what the veil hides. The rumours about the reason for her concealment range from a fearsome deformity - "frightful beyond endurance; a pig's, bear's, cat's or elephant's face," a mere "emptiness" - to supernatural beauty, a beauty "so dazzling that if [she] let it be seen all men in the world would run mad" and it would provoke the jealousy of Ungit herself (237). As a result, Orual becomes "something very mysterious and awful" (238) - the very charge she lays against the gods. There is fear in that mysteriousness, and suspicion. If, as Levinas proposes, the face is the site of real connection, then masking or veiling the face (whether Orual or the gods) is denying a relationship of equal or open exchange, of knowing.

Yet there is a strange paradox of recognition afforded to Orual even in this very act of concealment: the veil is a symbol of being both known and unknown. This paradox is crucial to

Bareface after all). Adey notes that Lewis wrote Orual "went physically barefaced in childhood and by the time she finished her tale in old age was psychologically barefaced" (C. S. Lewis: Writer, Dreamer, and Mentor 151), or even "spiritually" barefaced (22). 
the paradox of the hidden God: can God be both known and unknown, accessible and unfathomable? Orual's veil is an emblem of this paradox. Once, the King sends Orual from his presence, crying "Take away that one with the veil. [...] I know who she is. I know" (194). Her veil, though it hides her, is also her single most distinguishing feature. Orual later concludes that "My veil was no longer a means to be unknown. It revealed me; all men knew the veiled Queen" and if she then wished to be disguised, she should go "bareface" (289). Orual is recognisable but unseen when she is veiled, but after years of wearing a veil she is unrecognisable when she goes unveiled and all can see her. If she is veiled, others cannot see the insecure, terrified girl beneath, and are free to attribute to her any manner of complimentary characteristics, or mighty warlord-like abilities. If unveiled, after many years of the veil, Orual is similarly unlike herself: unrecognisable as the royalty she is. She wonders whether she "would look as Ungit to them [...] Perhaps if anyone saw me, they would worship me. I had become what the people, and the old Priest, called holy" (289). Adey writes that "Orual has ruled Glome justly and intelligently but veiled her face, so making herself distant and awesome [...] [having] thereby overlaid if not killed her own soul" (153) Here Lewis begins to address the thematic connection between holiness and darkness or the unknown (as in Orual's lament of the holy places being the dark places). In both her veiling and her unveiling Orual embodies the paradox of the known and yet unknown, just as the divine (Ungit, in this case) is paradoxically both known and unknown by her veil. Lewis's iterations of veils inhabit the definitions at both ends of the spectrum: identifying and concealing simultaneously. As Milbank suggests, paradox "allows us to understand what we thought was straightforward [...] as complex or different from what we originally assumed, and yet illumined" (88).

Lewis's veils have complicated the otherwise straightforward idea that veils hide, or, by extension, that holy places are dark, or that divine mystery is impenetrable. His use of veiling emphasises the unknowability of a person or deity whilst simultaneously illuminating them in some way. Lewis seems to be raising questions, moreover, that he does not intend to resolve completely: can the hiddenness of the divine simultaneously be a means of revealing or identifying it? Like Tolkien, Lewis does not shy away from this paradox, but seems instead to emphasise it. The concept is further complicated, as Adey rightly points out, by the "central weakness" (160) of the god's injunction that Psyche may not look upon his face.102 Whatever facelessness, masking or veiling, is attributed to the gods, it is the same kind of facelessness attributed to Orual. This is a far cry, it must be said, from the more overt didacticism of his

102 He writes: "To forbid a Christian to behold Christ her bridegroom has no meaning either on Earth where she cannot or in heaven where she forever will. So an act of disobedience that is meaningful only in the pagan myth and the fairy-tale has consequences that are meaningful only in the Christian mythos" ( $C$. S. Lewis: Writer, Dreamer, and Mentor 160). 
children's fantasy. In his theology, as in his story, Lewis's navigation of the paradox of known and unknown, mystery and revelation, incline the reader towards a reading that does not promise straightforward conclusions, but provides illumination in the search for answers.

If, as Milbank proposes, paradox presents "the difference between two things, and seeks for that which unites them - their relation" (91), then Orual is Ungit, in a sense, just as she is later told. By this I do not mean that Orual discovers that she is her own deity. Rather, Orual pours out her complaint, but by the end of the story the complaint has turned on her and accuses her and not the gods. That concealment, power, recognition, unknowability - in short, all that the reader has been taught to associate with her veil, and all that which forms her complaint against the faceless gods - is the very thing which unites her with them. Lewis here defamiliarises the identifying characteristic of his main character: her physical veiling morphs into the figurative veiling and mysteriousness of the gods. Many years after the events which began her narrative, Orual happens upon a temple, built to honour her sister Psyche (or Istra). The Priest of Istra tells the tale of the goddess Istra to Orual (not knowing he speaks with her half-sister), but the tale provokes Orual for it casts her as a sceptical, jealous sister and does not seem to her at all true. So, she resolves to write her own revealing account in retaliation, "telling what they [the gods] have kept hidden" (252). This is the accusation she levels at the hiddenness of the gods, and moreover what Lewis has been gradually building up to. Standing before the gods, Orual feels all the disadvantage of being on the wrong side of the veil, as it were. She takes issue with the idea that all knowledge is hidden behind the veil which covers the statue of Istra, and Ungit. "Now, instantly, I knew I was facing them - I with no strength and they all; I visible to them, they invisible to me" (254). But instead of encouraging the reader to simply accept the mystery of divinity without explanation, ${ }^{103}$ Lewis instead turns the question on the questioner. Neither these gods, nor Orual, have faces.

This facelessness is hinted at earlier in the novel, after her encounter with the God of the Mountain, when Orual's veil seems to estrange her even from herself. "Often," she writes, "remembering that it is sometimes the gods' way to turn us into beasts, I put my hand up under my veil to see if I could feel cat's fur, or dog's muzzle, or hog's tusks beginning to grow there" (184). She is concealed beneath her veil, even from herself. There is a veil, moreover, between her and the faceless gods which prohibits meaningful encounter and leaves her with "no answer" (259). The irony, as discussed above, is that Orual is similarly veiled - not only physically, but also in that she conceals part of her narrative. The trustworthiness of Part I (comprising over $80 \%$ of the whole book) is undone by her addendum chapters in Part II, in Lion, the Witch and the Wardrobe 75), or again "He's wild, you know. Not like a tame lion" (166). 
which she revokes many of her former conclusions. Lewis defamiliarises the mysteriousness of the gods by casting it into an expression of the facelessness of mortals. "How can they meet us face to face till we have faces?" Orual explains at last (305). Lewis's fiction encourages thoughtful exploration of difficult theological questions, so that the reader may approach either his literature or Biblical scripture with openness - that is, 'bareface.' Lewis suggests that all pretensions must be shed before there can be a face-to-face encounter, whether it is between Orual and her court, or the God of the mountain, or the reader and their God. Until the facelessness (or faithlessness) of the questioner is acknowledged, as Orual does her own, there can be no hope of a face-to-face encounter with the gods. Thus, instead of delving into the mysteries of a dis-embodied god, the riddle of facelessness (through the veiling motif) displaces the focus from the mysterious divine to the sceptical mortal. Sceptics are invited to turn the scepticism on themselves, to unveil themselves. The external paradox of knowledge and ineffability in relation to God becomes an inner paradox exploring the limits of the fallen self.

\title{
Masks as Transformation
}

Finally, Lewis suggests that masks have the potential to transform. ${ }^{104}$ In the chapter "Let's Pretend" in Mere Christianity (published in 1942, fourteen years before Till We Have Faces), Lewis suggests that masks may be transformative:

\begin{abstract}
May I once again start by putting two pictures, or two stories rather, into your minds? One is the story you have all read called Beauty and the Beast. The girl, you remember, had to marry a monster for some reason. And she did. She kissed it as if it were a man. And then, much to her relief, it really turned into a man and all went well. The other story is about someone who had to wear a mask; a mask which made him look much nicer than he really was. He had to wear it for years. And when he took it off he found his own face had grown to fit it. He was now really beautiful. What had begun as a disguise had become a reality. (187)
\end{abstract}

Lewis may have taken his cue here from the New Testament epistles, many of which describe cultivating certain attributes in terms of putting on clothing (see 1 Peter 5:5, "clothed with humility", or Ephesians 6:10-17 which speaks of putting on the armour of God). Ephesians especially has a distinct transformative undercurrent in the imagery of putting off an 'old self', and putting on the 'new' (Ephesians 4:24). In this excerpt, Lewis is talking about Christian living

104 This is in keeping with Joseph Campbell's meditations on the cultural significance of masks. Campbell observes that masks have a special significance particularly in religious contexts where "the gods and demons are not conceived in the way of hard and fast, positive realities" (21), and work "without correction upon the sentiments of both the beholder and the actor" so that the one wearing the mask "does not merely represent the god; he is the god" (21). Campbell suggests that the mask has a transformative effect on the wearer: in playing a god, the wearer takes on the likeness of God. 
and the Pauline idea of sanctification, that of 'putting on Christ' (see Romans 13:14) - the second example he gives therefore serves as something of a parable for that idea. Both stories describe a kind of good infection. In Till We Have Faces, as we have seen, Lewis successfully embodies both types in his veil/mask motifs. ${ }^{105}$ On the one hand, there are masks and veils which disguise and conceal, and on the other is a story in which the reality becomes the mask, which is then removed. The Beast sheds his beastliness as if it were a mask - which of course it was not at the point when he was cursed with beastliness. In his comment on masks, Lewis opens the reader up to the idea of a mask that transforms rather than hides. Lewis describes this process as "dressing up as Christ" (Mere Christianity 188) - an act which seems "a piece of outrageous cheek" but is something that "He has ordered us to do" (188). According to Lewis, there are two kinds of pretence: "a bad kind, where the pretence is there instead of the real thing" (that is, the mask that conceals) ${ }^{106}$ and "a good kind, where the pretence leads up to the real thing" (188). ${ }^{107}$

Lewis's masking/veiling motif therefore insists that the nature of humanity is something that is in flux - individuals are either moving towards Christ (in sanctification), or away from Him. This theology of in-flux, or even incomplete humanity is also apparent in Tolkien's fiction, as has been demonstrated above: all characters created within this ideological paradigm will themselves be something of a riddle, as their identity remains unresolved between these two poles. Just as the theology of sanctification asserts that humans upon the earth are not fully redeemed, so these fictional characters prove difficult to categorise or riddle through precisely because their authentic self is not fully revealed.108 This theology of sanctification may be part of the reason Tolkien and Lewis created characters who seem paradoxical and pulled between multiple identities. Paul Ricoeur writes in "The 'Image of God' and the Epic of Man" (1961) that part of the theology of creation is a theology of growing in the image and likeness of God. In creation theology, humankind was created in the image and likeness of God (see Genesis 1:2627), but has fallen, thereby marring the image. Ricoeur suggests an individual's development is plotted on the spectrum of taking on that likeness again (or failing to). He notes that the idea of

\footnotetext{
105 Something of this is enacted by Psyche, who on sacrificing herself to the fearsome shadowbrute becomes instead the bride of the God of the Mountain - and when she does so, she discovers that all brutishness in his nature is non-existent, just as the Beast in the fairy tale transforms into a man when the Beauty kisses him. The analogy breaks down, however, because it is not Psyche's goodness which made the God of the Mountain good, in the Chestertonian sense of 'a thing must be loved before it is loveable.' It was rather the incorrect assumption of his brutishness (itself a kind of mask) which fell away. ${ }^{106}$ An example of this might be seen in Puzzle the donkey, who embodies 'putting on Christ' wrongly. ${ }^{107}$ Lewis's analogy of good pretence might be thought of in terms of repeated practice (of an instrument or sport, for example), which leads to perfected performance.

${ }^{108}$ Understanding this will be essential groundwork to the following chapter on archetypes: the paradox of identity cannot be completely resolved and so characters will be expected to fit their archetypal moulds only partially.
} 
image-bearing in Genesis has a significantly transformative connotation: ideally, a person would develop so that "what was mortal should be vanquished and absorbed by what is immortal, and that man should become as the image and likeness of God" (38). His idea of the 'epic of man' is that of a person becoming (increasingly like God). André LaCocque paraphrases Ricoeur's reflections in "Cracks in the Wall": "[m]an is created in the form of the Elohim, that is, according to a celestial model that uproots him from the sphere" (9). God took on human characteristics, was incarnate or 'anthropomorphic,' as Christ Jesus. Correspondingly, the image of God upon humankind allows for the human to take on God-like attributes: to be 'theomorphic.' In Mere Christianity, Lewis describes the 'good pretence' of "dressing up as Christ" (188) in order to become "a new little Christ" (192). His analogy of the beautifying mask represents this idea of theomorphism: the ongoing, dynamic change towards becoming a mini-Christ. This likeness is both present and simultaneously in process: now and not yet. The image of God upon humankind is present, but incomplete. Thus, the riddle of personhood requires a spectrum, not a fixed and definite representation: humanity as the image of God defamiliarised, fallen, partial, in process. Paradoxical characters such as those Tolkien and Lewis wrote, ambiguous, presently imperfect but incipiently perfected, are more deeply understood when figured as fallen representatives of that dynamic image.

Despite his expression of the 'good' pretence of sanctification, Lewis acknowledges the pull in the opposite direction too, as Tolkien does with Gollum. The extent to which the created being bears the image of its Creator is negotiable, in flux. As Milbank has pointed out, if the fantasy world is built upon the Thomist basis, in which the author holds to "a belief in the Creation as wholly good, and to existence itself as a good, which is not lost, even if one becomes Satan" (76), evil is expressed as a corruption or departure from original 'form' altogether. Lewis's masked or veiled characters are accordingly described in inhuman terms, just as Orual's veil associates her with wild animals and with ideas about supernatural abnormality; she fears a departure from identifiable humanity. Another example is the Priest of Ungit who seems to transfigure when he dons his ritual bird's head mask. This mask is usually worn on his chest, making him somewhat monstrous, "as if there were a bird growing out of his body" (Till We Have Faces 19). He is no longer a mere man but a grotesque: "a great bird-headed man, or a bird with a man's body" (115). ${ }^{109}$ Once Psyche even wonders "[i]f he is still the Priest when he puts on his mask; perhaps he becomes a god when he wears it" (116). Of course, the Priest's bird mask is not of the same ilk as the beautiful mask of Lewis's original analogy: one transforms a monster into a man, but the Priest's mask strips the man of even the semblance of humanity.

${ }^{109}$ It is worth noting that medieval mystery plays and paintings depicted Lucifer (a fallen angel) with feathers. 
Similarly, in Lewis's Narnian fables, degeneration of form is portrayed by the talking beasts of Narnia becoming dumb, as seen with Ginger the cat in The Last Battle. The mark of Aslan on his creation (the equivalent of the image of God on man) is speech: his instruction is, "awake. Love. Think. Speak" (The Magician's Nephew 108). If this is an expression of the creator's image impressed upon the lesser beings - to be a loving, knowing, talking beast, just as Aslan was a loving, knowing, talking lion ${ }^{110}$ - then the loss of speech for a Narnian would be a dramatic loss of that image-bearing quality. Ginger, the cat, was frightened to dumbness when it faced Tash, a demon called into existence by Shift's con. All are horrified to discover “[i]t can't talk. It has forgotten how to talk! It has gone back to being a dumb beast" (The Last Battle 105). Not only unable to speak, Ginger also shows all the evidence of having his very character erased. The use of the pronoun "it", rather than 'he' or 'Ginger', merely emphasises the dehumanising change, the loss of personhood, and even of soulful existence. If that likeness was a mark of the Creator, the lack of it clearly demarcates a void where the mark had been eradicated. Part of the paradox of personhood, according to Lewis, is that it is always moving towards one of these two poles, but never fixed in one direction: moving either towards the fallen Adam or towards the incarnate Christ. 111

\section{Conclusion}

Tolkien and Lewis are concerned to foreground the search for truth and encourage inquiry, while holding both in tension with a reverence for the unfathomable. Both Tolkien and Lewis subscribe to a Christianity that is open to and can withstand, intellectual scrutiny; for this reason, it is important that wherever the mystery of the divine is concerned, whether in their fiction or in reality, discussion and inquiry be encouraged rather than foreclosed. Their predilection for riddle, paradox, enigma, and ambiguity works to encourage a thoughtful, engaged reading, reading which mimics the kind of inquiring necessary to pursue intellectually questions of theology. The books establish early on the need to puzzle through obscurity, both in relation to characters - Puzzle, Saruman, Gollum, Aragorn, Orual, and others - and in relation to God himself. The obscurity which surrounds the divine, the masking and veiling of characters, the paradox of selfhood - all these unknowns are the authors' expressions and explorations of the search for truth through obscurity. To some degree, they suggest, obscurity can be replaced by understanding, as in the riddle of the Saruman/Gandalf figure. Yet the authors show that even the image fails, the image of God upon humankind is identifiable but incomplete and in

\footnotetext{
${ }^{110}$ See, for example, the sense of shared form when one of the lions boasts about "Us Lions. That's what I like about Aslan. No side, no stand-offishness" (The Lion, the Witch and the Wardrobe 158).

111 I explain this formula further in the following chapter.
} 
flux; the mask conceals as well as represents. The divine is a mystery, but then so is humanity. Paradox and riddle may offer illumination or truth, but may also remain unsolvable. Tolkien and Lewis attempt to communicate what is sacred in their fiction, knowing that the sacred can only be partially described by profane art. But it is described. The model, as Milbank explains, is only used "paradoxically, to show in what way the types fall short" (104). What remains, and this is the important thing, although 'seen through a mirror, darkly,' is nevertheless seen. 


\section{Chapter Three: Christ (Anti)Types}

Paul Ricoeur suggests that God's image on humankind should be thought of "not as a hereditary mark, but as the root of human creativity; [...] not the residual trace of a craftsman who has abandoned his work to the ravages of time, but as a continuous act in the creative movement of history and duration" ("The Image of God' and the Epic of Man" 37). For Ricoeur, the phrase "image of God" refers not only to a kind of static resemblance between God and his creation, but also to a kind of hereditary creativity in created beings. In other words, the human capacity for creativity testifies to the greater creativity of a creator - an idea that recalls Tolkien's concept of sub-creation, discussed above. As human beings, though equally created in the image and likeness of God, are varied and multi-faceted, so too are the characters that Tolkien and Lewis create or invent, who can be variously seen as representations of Adam and Christ figures. While making strange can only be performed in response to the familiar, the bounds of the familiar contain infinite scope for possibility. Tolkien maintains that even 'subcreation' is potent: it is "an enchanter's power" to create, to imagine, to make "new form" or "fantasy" ("On Fairy-Stories" 62): it is both familiar and the point of departure into defamiliarised territory.

Despite ambiguity of the characters in the fiction of Tolkien and Lewis, the subject of my previous chapter, even the most complex of these characters is plotted on a trajectory towards either an Adam figure or a Christ figure. In other words, they are plotted according to a human bent (emphasising their humanity and flaws), or a Christological bent. Biblical typology offers an interpretative framework for reading the Old Testament in the light of what is known about Jesus Christ from the New: it suggests character connections by reading certain Old Testament characters (such as Adam) and events as pre-figuring Christ. This framework finds its source in the New Testament when Christ refers to himself as Jonah (Matthew 12:41). Exegetes in the early church who developed and adopted the idea of typology and who practised that mode of reading did so on the authority of the Bible, seeing in this statement by Jesus and others by Paul an inspired precedent for the practice. Typology has been used to understand and validate Christ's identity based on the Old Testament, both in terms of its prophecies and its recurrent longing for a Messiah. Tolkien and Lewis have both relied on and defamiliarised Biblical Adam and Christ figures in their fantasy fiction. There are numerous disparate ways of thinking about Adam characters. Adam may represent the fallenness of humanity - such as Boromir and Gollum in Tolkien's The Lord of the Rings, and Digory in Lewis's The Magician's Nephew. Adam's 
failing is simultaneously his own and imputed to all - "as by one man sin entered into the world, and death by sin; and so death passed upon all men, for that all have sinned" (Romans 5:12). Another Adam, as a type of Christ, foreshadows the need for a redeemer: "Therefore as by the offence of one judgment came upon all men to condemnation; even so by the righteousness of one the free gift came upon all men unto justification of life" (5:18). For this reason, Jesus Christ was known as the Second (or Last) Adam (see 1 Corinthians 15:45-48): the one who came to undo what Adam did, and to do what Adam could not. Christlike resemblance in the characters can be found in symbols of light and life, and in Messianic roles and characteristics. Whilst, for Lewis, the character of Aslan has many Christlike attributes in animal form - a literalising of the Old Testament metaphorical prophecy about the 'lion of Judah' (Hosea 5:14, Revelation 5:5) Tolkien splits the threefold office of Christ (prophet, priest, and king) between Frodo, Gandalf and Aragorn. These methods are employed by the authors, even if only to expose their limitations, or the places where the (representational) type falls short of the (ideal) antitype. This chapter explores this characterisation in the fictional worlds of Tolkien and Lewis, in order to show how characters are defamiliarised, in relation to familiar (archetypal) material, most of which is Biblical.

\section{Type and Antitype}

This chapter focuses on the typological notions of 'type' and 'antitype', and their specific relation to Adam and Christ figures. Typology is not to be confused with archetypal analysis. In some respects, archetypes and typological types work in opposite directions: where archetype signifies the standard form from which everything else deviates, ${ }^{112}$ a type is an imperfect forerunner to the perfect antitype. The general resemblances implied by the terms image and likeness' give way to the much more specific and particular relationship between type and antitype. According to the Dictionary of Biblical Tradition, typology is "a metaphysical point of correspondence between type and antitype, although occasionally, as in the typological link between Adam and Christ in 1 Corinthians 15:22, the connection is a point of contrast" (Jeffrey

\footnotetext{
112 Archetype is defined as "[ $t$ ] he original pattern or model from which copies are made; a prototype" according to the Oxford English Dictionary ("Archetype, n."). Both archetypal or typological character patterning, however, may fall under the banner of defamiliarisation because each character iteration is unique; there is always some way in which each archetype is defamiliarised from other iterations, as the many iterations of folk and fairy tales over the years will testify. Thus, in using character patterns, Tolkien and Lewis deliberately and paradoxically employ similarity and difference in their fiction: even though characters may seem to fit one category, they never completely embody that category, or they embody multiple at once, as discussed in my previous chapter. Frodo, for instance could be simultaneously classed as the hero, the chosen one, the orphan child, the possessed, and yet he is not any one of these alone.
} 
792). Put simply, the 'type' foreshadows, and the 'antitype' is its culmination. Northrop Frye puts it like this:

Everything that happens in the Old Testament is a "type" or adumbration of something that happens in the New Testament, and the whole subject is therefore called typology, though it is typology in a special sense. Paul speaks in Romans 5:14 of Adam as a typos of Christ [...]. What happens in the New Testament constitutes an "antitype", a realized form, of something foreshadowed in the Old Testament. (The Great Code 79)

As Frye explains, the "New Testament writers [...] regarded the Old Testament as a source of anticipations of the events in the life of Christ" (78). Other notable types include David as the promised king (to whom Christ was antitype), and Elijah as a prophetic voice calling for repentance (to whom John the Baptist was antitype). Because both the New Testament and the Old rely on each other within Christian thinking, Frye suggests that the "two testaments form a double mirror, each reflecting the other" (78). The New acts as "key" to the Old (79).

The Adam/Christ pairing is suggested by the apostle Paul in the first epistle to the Corinthians, where he says, "For as in Adam all die, even so in Christ shall all be made alive" (1 Corinthians 15:22). In the case of Adam and Christ, Christ is the antitype to Adam (the type) because he completes and fully embodies the imperfect pattern set by Adam, able to meet and overcome the obstacles Adam, the type, could not. Adam is not the only type to Christ's antitype - for example, the Bible introduces the sacrificed son as a type in Abraham's near sacrifice of his son Isaac (see Genesis 22), but Christ, as the antitype and Son of God, goes through with the sacrifice unto death. But the relation of Adam as type to Christ's antitype is clear and central. As the representative of humankind, Adam undergoes temptation and succumbs to it, whereas Christ undergoes temptation and overcomes. Adam (as type) foreshadows the way that Christ (as the antitype) would overcome the obstacle that was Adam's undoing. Type might even be thought of as a defamiliarisation of antitype.

When it comes to the fiction of Tolkien and Lewis, this notion of typological patterning is extended: where the New Testament has suggested ways for the Old Testament to be read typologically, Tolkien and Lewis suggest that anything can be read typologically. ${ }^{113}$ Lewis's preChristian sacrificial system in Till We Have Faces, for example, manages to evoke the Old Testament sacrificial system and also Christlike self-sacrifice in Psyche. Frye hints at the applicability of typological readings when he defines typology as "a figure of speech that moves in time: the type exists in the past and the antitype in the present, or the type exists in the

\footnotetext{
${ }^{113}$ As if to illustrate this, Brent Nelson has written on the "Cain-Leviathan Typology in Gollum and Grendel" (2008). As his examples do not pertain to Adams and Christs, however, the associations he makes are not pertinent to this thesis.
} 
present and the antitype in the future" (80). In Biblical typology, type always precedes antitype, but this is not true for fiction. Typology involves analogy - and analogies do not depend on chronological sequence. Characters invented in fiction after the time of Christ can be types of Christ, in the sense implied by Frye's double-mirror, in the same way that Noah or Jonah are.114 Frye's idea of the 'double mirror' suggests a transcendence of time: the presence of Christ can be found in everything and everywhere. This idea calls to mind Tolkien's idea of 'applicability' in his "Foreword to the Second Edition" of his The Lord of the Rings, in which he details his writerly preference for "history, true or feigned, with its varied applicability to the thought and experience of readers," which he later specifies is "the freedom of the reader" (The Fellowship of the Ring xxii). Frye suggests that typology is an "extremely powerful and subtle form of metaphor" (87); it is never reductive: “A can only be A, never B, and to assert that A 'is' B overlooks all the real differences between them" (87). The richness of the typological connection is to retain the combination of identifying something as an individual of a certain class/category as well as something identifying with a certain class/category. To use Frye's A/B reasoning, for example, Gandalf is not meant to be Christ; identifying Gandalf as a Christ figure, or identifying him with Christ, is not to say that he is the Christ of Tolkien's Middle-earth. Rather, this classification illuminates and enhances the character and person of Gandalf, and sheds light on Tolkien's understanding of Christ by association.

It is important to keep in mind that Tolkien and Lewis are not recreating the Biblical Christ, but adding to the pantheon of Christ types. ${ }^{115}$ And if Adam was a type of Christ, then Adams in fiction are also, in a strange way, types or defamiliarisations of Christ too. The differences, or departures from the original or traditional Christ in Tolkien and Lewis serve to accentuate the ways in which they explore Messianic attributes or characteristics, rather than the character of Christ himself. Tolkien and Lewis use types and antitypes deliberately to explore aspects of Biblical characterisations and what they mean to doctrine, so that one iteration enriches the understanding of the other. Thomas Honegger writes that Tolkien would not only have been familiar with "the typological way of thinking and perceiving patterns," but that typology would be to him "a highly attractive method for linking his fictional works to the

${ }^{114}$ Frye, however, does not imply that the Biblical types were fictional, saying that "both testaments of the Bible, however oblique their approach to history, deal with real people and real events" (85). 115 As well as other typological connections. Michael T. Jahosky, for instance, in The Good News of the Return of the King: The Gospel in Middle-earth (2020), expands on Tolkien's own association of the dwarves with Old Testament Jews/Israelites in Letter 176, where Tolkien writes that they are "at once native and alien in their habitations, speaking the languages of the country, but with an accent due to their own private tongue" (Letters 229). Jahosky further expounds on the division of kingdoms: Moria (south) and the Lonely Mountain (north, Judah). The dwarves' Jewish connections have been discussed by Matt Lebovic in "Are Tolkien's Dwarves an Allegory for the Jews?" (2013), and by Rebecca Brackmann in “'Dwarves are not Heroes': Antisemitism and the Dwarves in J. R. R. Tolkien's Writing” (2010). Although these are interesting connections, I am limiting my discussion here to types of Adams and Christs. 
revealed truth of the Gospels without having to recur to blatant anachronisms or to violate the precepts of his Christian faith" (“We Don't Need Another Hero'” 11). Aragorn sheds light on the character of a returning king, for example, in keeping with the Christological office, but he does not embody other Christlike roles, such as sacrificial lamb, or bearer of the sins of the world (these particular roles are embodied in Frodo, as I shall later demonstrate). Although there are many character patterns to be explored, I have chosen to limit my analysis specifically to only Adam and Second Adam (Christ) characters. These Adam types are representative figures whose actions bring a fall of some kind, either individual (as for Boromir) or collective (as for Digory). Each Adam must have a Second Adam, and both Tolkien and Lewis have created a wide range of Christological iterations. It should be remembered that in the work of Lewis and Tolkien, the embodiment of type is only partial. Lewis's Aslan, for example, may appear straightforward, but his defamiliarisation of Christ as lion is consciously counter to the sacrificial lamb of the Old Testament, even as Aslan becomes a sacrifice. Tolkien provides an exploded version of the threefold office of Christ, but defamiliarises by separating these offices between three characters so that they are never united in a single figure.

\section{Figures of Adam}

As the common type of Christ, according to the book of Romans, Adam represents a gap, or a damage which the antitype is meant to repair. Adam is a complex figure: he is a fallen individual and representative figure of humanity's fallenness; he is also the cause of humanity's fallen state. He represents the frailty of all humankind, the foil to Christ's redemptive act. Paul's epistle sums it up like this: "For since by man came death, by man came also the resurrection of the dead. For as in Adam all die, even so in Christ shall all be made alive" (1 Corinthians 15:2122). Adam can therefore be understood as a representative man, for whom the man Jesus was a necessary counterpart. If it were not for the Fall, there would be no need for redemption. The same logic of 'so in one, all' that governs Adam's and mankind's Fall applies to the atoning sacrifice of Christ. The sacrificial system of the Old Testament was built upon the premise that the wrongdoings of one could be moved onto another and be atoned for by another. Thus, the sacrifice was also representative: the actions of one are attributed to all. We see the same idea in the works of Tolkien and Lewis, almost literalised: Frodo, as a Christ figure, can put right the failure of Isildur; Aslan is somehow an acceptable, and legal, substitute for Edmund. There is not a generalised sense of wrong to be put right; the wrongs are always linked to the actions of a single character so that the putting right can be accomplished likewise by a single character. The role (even the existence) of a saviour depends upon the existence of an Adam. 
The Lord of the Rings contains several Adam figures: Boromir, Isildur, Gollum, even Denethor. It is worth noting, however, that Adam acted in an unfallen world, causing it to fall; Tolkien's Adam figures inhabit a fallen world, and thus the context of their temptation is different. All four characters have the Ring within their grasp and bring doom and destruction either upon themselves or Middle-earth by yielding to its temptation and promise of power. It is Isildur's fall, failing to destroy the Ring when he had the chance, through which we first understand the Ring as the object of temptation. Isildur may be said to be the very first Adam figure in The Lord of the Rings. His temptation was not in taking what was forbidden, but rather in keeping what he should have destroyed. It is reminiscent of the General Confession from the 1559 Book of Common Prayer: "We have left undone those things which we ought to have done, and we have done those things which we ought not to have done, and there is no health in us." Such phrasing is key in Tolkien's take on the Fall: he depicts a fall as either a sin of commission (Boromir acting), or a sin of omission (Isildur failing to act). Isildur has the opportunity to destroy the Ring of Power, but keeps it for himself and is ultimately slain, allowing evil to flourish unchallenged in Middle-earth.116 Gollum fails to act, and his punishment is the loss of form and selfhood in thrall to the Ring. And Boromir acts, but he is consumed by his own hunger for power, his desire to protect his own people, and the belief that he will be strong enough to wield the Ring and resist its evil. He is killed shortly after his unsuccessful attempt to take the Ring. Tolkien's characters are morally culpable for their response to the test, whether they act or fail to act. Each fall of Adam brings about disastrous consequences, requiring redemptive action.

The Adam figures are each sympathetic to some degree; their frailty is understood as common to every person. In fact, David Callaway writes (of Gollum as an Adam figure) that Adam is "an emblem of the internal dilemma faced by all creatures in a Christian-based cosmology" ("Gollum: A Misunderstood Hero" 17). As Verlyn Flieger has pointed out, we identify with someone like Frodo, who "doubts, feels fear, falters, makes mistakes; he experiences, in short, the same emotions we experience" ("Frodo and Aragorn: The Concept of the Hero" 124). Both Tolkien and Lewis excel at humanising their fallen characters. Their characters wrestle with human frailty against the power of sin and temptation - from Tolkien's Gollum, to Boromir, to Sam, and Lewis's Digory. There is space for the reader to wonder whether Sam might have become Gollum, or Lucy the one who betrayed information to the White Witch. For critics such as Penelope Lively, all but the "Judas-figure" Edmund and redeemed "unfortunate Eustace" are

116 The Ring is itself an iteration of the fruit of temptation for Isildur (known as Isildur's Bane). It is defamiliarised, not least in that it is carried around with the characters and constantly present. Lewis also picks up on the trope of the Ring of temptation in The Magician's Nephew, when the bright rings offered by Uncle Andrew have an effect on Polly comparable with the forbidden fruit. 
no more than "cardboard figures" ("The Wrath of God" 127), and for her, as for other readers, it seems that certain characters have been tested as a token inclusion, and are never in any serious danger of falling. Even Edmund and Eustace, as Boromir, it may be argued, are set up to fall and be reclaimed. Whether or not the reader takes this possibility seriously, the pathos of these moments of struggle cannot be denied. Lionel Adey notes that Edmund's treason is "morally compelling" whatever the reader's conclusion about it is, and the child reader "cannot but condemn" Edmund's willingness to betray his family, and "still more his pretended disbelief" in Narnia later (C. S. Lewis: Writer, Dreamer, and Mentor 188-9). Boromir's passing, as recorded by Hammond and Scull, has struck readers as he makes "a good end according to the warrior epic" and dies having atoned for his actions against Frodo and Aragorn in a "state of grace", with his last thought for the people of his city (The Lord of the Rings: A Reader's Companion 359). Even if these situations are contrived in order to allow the characters to experience grace after a fall, both Tolkien and Lewis emphasise the applicability of the character's situations. They attempt to show that anyone might be tempted, wrestle with temptation, and overcome it.

Biblical narrative has a strong tradition of encouraging listeners to find personal significance in story. Biblical parables are (almost by definition) applicable to those who hear or read them. Archbishop Rowan Williams explains:

$[\mathrm{w}] \mathrm{e}$ are invited to identify ourselves in the story being contemplated [that is, the parable], to re-appropriate who we are now, and who we shall or can be, in terms of the story. Its movements, transactions, transformations, become ours; we take responsibility for this or that position within the narrative [...] as if we did not know the end (51)

Robert Murray, a younger friend of Tolkien's, a Catholic priest, and an early reader of The Lord of the Rings, suggests that Tolkien's work bears "the nature and power" of parables (41) - by which he means "a skilful use of the arts of speech so as not to impose or compel, but to invite a response in which the hearer is personally active" (42). Perhaps this empathetic applicability is a defining feature for both Tolkien and Lewis in their representations of Adam: Adam's frailty must be recognisable and felt by the reader too. Having empathy for Adam's frailty, furthermore, opens access for sympathy to those at the very extreme end of the spectrum: the Edmunds and the Gollums, even though they seem initially to be unworthy. The authors delay the moment of recognition, concealing just how susceptible all are to the same course. Gollum, for example, is in thrall to the Ring, so powerfully altered by his obsession that Faramir describes him as eaten with malice "like a canker, and the evil is growing" (The Two Towers 691). The reader has no experience and no real reason to sympathise with his plight. But when 
Frodo and Sam, the humble characters, begin to display signs of that same obsession, even Gollum becomes less strange.

The reader is drawn in by sympathising with Frodo and Sam. Sam's brief stint bearing the Ring is particularly dramatic in its effect upon him:

As Sam stood there, even though the Ring was not on him, but hanging by its chain about his neck, he felt himself enlarged, as if he were robed in a huge distorted shadow of himself, a vast and ominous threat [...]. Already the Ring tempted him, gnawing at his will and reason. (The Return of the King 901)

Sam, who has been aware and suspicious of the Ring's evil influence on his beloved Frodo and who did not pity Gollum's miserable state as Frodo did, is a powerful testimony to the power of the Ring and its temptation. For Sam to be so suddenly taken in by the Ring's power speaks volumes of its capacity to corrupt. Within minutes of first taking it up in Shelob's lair, Sam has already yielded to the dangerous act of putting it on, "not aware of any thought or decision" to do so (The Two Towers 734). Then, Sam is reluctant to give it up, even though he himself calls it a "terrible burden" (The Return of the King 911). In this way, Tolkien regularly presents us with evil, irredeemable characters (such as Gollum and Denethor) and then humanises them by making the books' heroes as equally corruptible. Sam and Frodo might well be early versions of Gollum as each time they are tempted we are aware how easily they might capitulate to the will of the Ring; Boromir may be an early version of Denethor, as both nearly brought ruin to all in reaching for power through a destructive tool of Sauron (the Ring for Boromir, and the palantír for Denethor); and thus Faramir might have stumbled just as easily as Boromir did. Even the Elf Galadriel must suffer and overcome the temptation of the Ring. Tolkien humanises where the reprobate archetype lacked humanity.

As we can see, Tolkien takes pains to make sure that what strains the limits of sympathy is made human again. Tolkien makes the reader aware that the fallen one is only representative, and his actions could just as easily have been committed by another. So it is with Boromir, ostensibly a great hero whose desire for the Ring overcomes him. The reader is familiar with its dangers: Boromir's belief in his ability to use the Ring for good does not convince; great men (such as Gandalf and Aragorn) are suspicious and refuse to take it. It is Boromir's lesser known and milder brother Faramir who makes it possible for the reader to empathise with Boromir or at least brings the tragedy of Boromir's situation to bear upon the narrative, showing Boromir's actions to be credible and persuasive, but inadequate. Just as Tolkien uses Frodo and Sam to suggest the possibility of sympathy for Gollum, so Faramir powerfully evokes the frailty of Boromir, "the proud and fearless, often rash, ever anxious for the victory of Minas Tirith (and his own glory therein)" (The Two Towers 671). Boromir is not an evil character (at least not in 
the same way that Sauron is, for example). Adam is never described as a wholly evil entity, after all; he is not a fallen angel, but simply human. In fact, Boromir's hope for glory and victory fits the classical archetype of the hero. He has "plans for great alliances and glorious victories to be," he dreams of becoming "a mighty king, benevolent and wise" (The Fellowship of the Ring 398). It is even hinted that the hobbits' protection from the evil in Middle-earth is partially due to the efforts of Boromir and his people to keep them safe (see The Fellowship of the Ring 397). Yet Boromir experiences a radical fall after his visions of saving his people lead him to attempt to take the Ring from Frodo by force. He scarcely lives long enough to repent of it, saying "I am sorry. I have paid" (The Two Towers 414). In many ways, Faramir shares these hopeful visions for the glory of his people - a point which Tolkien emphasises in order to powerfully recall Boromir to the reader. Indeed, at the moment that Faramir has the Ring and its bearer in his clutches, all seems lost. Faramir, too, hungers for glory. In fact, as the reader discovers, Faramir has even more reason than Boromir to desire the power of the Ring. His father is Denethor, the Steward of Gondor, who has deemed the Ring "a mighty gift" for Gondor (The Return of the King 813). Denethor had loved Boromir more than Faramir, so Faramir stood to gain much in his father's eyes if he had brought the Ring to him when Boromir could not. Readers (and hobbits alike) are in suspense to see how this second Boromir will rise to the occasion. Even Faramir is aware of how exactly his situation mirrors his brother's:

The One Ring that was thought to have perished from the world. And Boromir tried to take it by force? And you escaped? And ran all the way - to me! And here in the wild I have you: two halflings, and a host of men at my call, and the Ring of Rings. A pretty stroke of fortune! A chance for Faramir, Captain of Gondor, to show his quality! (The Two Towers 681)

In this moment, the parallels are evident between his temptation and Boromir's, but Faramir has an even greater advantage: how much easier it would be for him, his men outnumbering the hobbits, to seize the Ring - the hobbits have no defence. Tolkien's reader is capable of sympathising with the severity of Faramir's temptation, and perhaps could not even hold him very blameworthy were he to take the Ring: such is the nature of the Adam-figure that Tolkien conjures in his writing. Faramir's plight makes accessible even Boromir's motivations, where once Boromir seemed estranged from the heroism he might aspire to by suddenly falling into the role of villain in attempting to take the Ring. When Faramir does not take advantage of the situation, his action is commended by Sam's words: "Captain, my lord [...]. You took the chance. [...] Yes sir, and showed your quality: the very highest" (682).

In passing the test that was too much for Boromir, Faramir acts as a second Adam to Boromir's Adam - he is not quite the Second Adam, or a Christ figure, yet he evokes another kind of (unfallen) Adam, one who resists temptation. The relationship of Boromir and Faramir 
and the similarities between them underline the typological parallel. Tolkien writes in the appendix dealing with the Stewards of Gondor that although Faramir's valour was esteemed less than his brother's, "it proved otherwise at the test" (The Return of the King 1057). This is exactly what is meant by the idea of a Second Adam. Furthermore, Faramir is in many ways a deliberate evocation of Boromir. Both men physically resemble each other, alike "in stature and bearing, and in their manner of speech" (The Two Towers 657) and Faramir is "much like his brother in looks" (665). Their hope to win the love of their father and bring glory to Gondor is part of a noble desire for the protection of their people and the defeat of evil. Because he and Boromir are so similar, Faramir's temptation appears to be a reiteration of Boromir's own. In departing from the actions of Boromir, however, Faramir becomes Boromir as he should have been. ${ }^{117}$ Yet Tolkien stops Faramir short of fully inhabiting the office of Christ-as-Second-Adam, who reverses the effects of the Fall in the world.

To understand the role of Adam in a typological framework, it is necessary to understand what he represents doctrinally. Biblical doctrine concerning death stems directly from Adam's fall, due to which death came into the world, and Adam's descendants were stained with 'original sin.' Lewis explores this doctrine in The Magician's Nephew, wherein death (embodied in the Witch) is brought into the unfallen Narnia by Digory, the Adam figure. At the end of The Magician's Nephew, the chronicle which features the creation of the Narnian world, the Witch appears in a garden strongly reminiscent of Eden, where she tempts the boy Digory to abandon his quest for Aslan and take an enchanted apple for himself. It seems clear that this scene echoes and reimagines the snake's temptation of Adam and Eve in Genesis. The scene of Digory's fall, however, occurs at the striking of the mysterious bell in Charn and not the fruit orchard in Aslan's country. Lewis suggests a very specific doctrine when he chose to recast Adam's story in this way. The Genesis story is generally taken to account for the presence of sin in the world, "that one of the good things [God] made, namely, the free will of rational creatures, by its very nature included the possibility of evil; and that creatures, availing themselves of this possibility, have become evil" (Lewis, The Problem of Pain 63). Lewis proposes here that sin occurs through the will, rather than simply the act of disobedience. Once corrupted, Lewis says, the spirit gives way to flesh, bringing it under "the control of ordinary biochemical laws" to suffer "whatever the inter-workings of those laws might bring about in the way of pain, senility and death" (77). Therefore, Lewis's theology of the Fall was never purely about the command a point that critics like Naomi Wood, for example, in "Paradise Lost and Found: Obedience, Disobedience and Storytelling in C. S. Lewis and Phillip Pullman," have not quite addressed.

117 The same thing happens with Gandalf and Saruman: Gandalf declares that he is Saruman, "Saruman as he should have been" (Tolkien, The Two Towers 495). 
Critics like Wood and Laura Miller (author of The Magician's Book: A Skeptic's Adventures in Narnia, cited above) reduce Lewis's Narnian stories to a narrative of obedience to a dominant authority. J. B. S. Haldane in one of his famous anti-Lewis essays, "More Anti-Lewisite," summarises Lewis's representation of his Fall theology in these terms: "For him, human freedom is a mere choice between alternatives presented to our souls by supernatural beings. For me it is something creative, in the sense that each generation makes newer and greater possibilities of good and evil" (255). Lewis shows that Digory's fall is less about disobedience or the pitfalls of disobedient curiosity, than it is about a lapse of faith. ${ }^{118}$ For Lewis, the Biblical Fall of Adam was about more than blind obedience, and he felt at liberty to reimagine it in very different terms.

In The Magician's Nephew, Digory Kirke and Polly Plummer find themselves in the crumbling world of Charn (having been sent into another realm by the dubious magical experiments of Digory's sinister uncle), where the evil Witch lies in an enchanted sleep. Although Polly has her own fall, for the vanity of an offered ring not a forbidden fruit, ${ }^{119}$ our focus is on Digory Kirke whose actions are not so forgivably naïve. Instead of a forbidden fruit as in Genesis 1-3, there is a bell; instead of spoken temptation, there is the inscription beneath the bell:

Make your choice, adventurous Stranger;

Strike the bell and bide the danger,

Or wonder, till it drives you mad,

What would have followed if you had. (50)

Many elements of the Genesis Fall are present, defamiliarised - not least because the decisions are being made by a child, not a mature adult: there are Adam and Eve represented in Digory and Polly; there is the temptation to do something which promises ill results; there is abuse of free will - but this version exhibits no disobedience per se. Instead, it turns on a nebulous spectrum of free will, as Lewis had intimated in The Problem of Pain. Lewis has thus defamiliarised the sense of transgression: in Digory's case, striking the bell was not actually forbidden. Although it was not a choice with a clear distinction between transgression or obedience, Digory was fully aware of the risk, and of Polly's misgivings: “We don't want any

118 Lewis is not condemning Digory's actions as a punishment for being too curious. It seems there is a kind of good curiosity which he venerates. Indeed, it is Digory who theorises about the real use of the 'outgoing' and 'ingoing' rings as portals to other places (thus disproving his Uncle), and furthermore it is Digory who proposes exploring other worlds before going back to their own. Lewis observes "Digory was the sort of person who wants to know everything, and when he grew up he became the famous Professor Kirke who comes into other books" (37-38). Curiosity clearly was not Digory's transgression.

119 While Polly's actions were not "blatantly sinful", Kathryn Walls notes that they represent the seed of what could develop into potentially more disastrous actions and consequences, even if naïve ("When Curiosity Gets the Better of Us" 344) 
danger," she says, scorning the inscription's provocation that works so powerfully on Digory, "As if anyone would!" (50). He nevertheless strikes the enchanted bell, which awakens the Witch. More than that, he physically manhandles Polly, whom he has been sent to protect, preventing her from stopping him or escaping. Thereafter, their attempts to escape the Witch prove futile. Digory sets in motion events he is powerless to stop: the Witch enters Narnia. From the moment he strikes the bell he is responsible, and the consequences are on his head. And so, though not explicitly disobedient, Digory falls, and brings sin and death into the newly-created, unfallen Narnia.

What is particularly interesting about Lewis's iteration of the Fall is that his Adam figure is both a type of Adam in his fall, and later, Adam's antitype: Lewis embodies both typological forms in a single character: Digory is given the chance to be (partially at least ${ }^{120}$ ) his own antitype, where usually the antitypal redeemer is a separate figure. As Aslan says, "Adam's race has done the harm, Adam's race shall help to heal it" (126). Lewis has thus defamiliarised the Adam/Christ typology in casting a single human character as both type and antitype. Even Digory's name gives some clue to his symbolic significance in the story: Lewis seems to be combining the imagery of the one who falls ('Digory' is similar to the French d'égarer - to err, or wander), and the community of the saved (through 'kirk', meaning church). Being both fallen and redeemed, Digory is emblematic of Christians. Lewis casts Digory as his own second Adam, suggesting a kind of Christlikeness, though it is not as overt as Aslan's Christlikeness. To remedy his involvement in bringing the Witch to Narnia, Aslan gives Digory a quest to recover a magic apple, which will grow into a tree to protect Narnia from the Witch for some years. So Digory and Polly find themselves in the Eden-esque setting of Aslan's garden. Both the Biblical text and Lewis's incarnation feature a paradisal garden in a newly created and perfect world, the boy and girl, the tempter, the forbidden fruit, and even an allusion to eternal life (Eden's Tree of Life, and Lewis's phoenix ${ }^{121}$ roosting in the tree). These obvious parallels, paradoxically, draw our attention to the way in which this part of Lewis's narrative diverges from the traditional Genesis account. Because the fall has already happened, this scene powerfully recalls the elements of the Biblical story to suggest a reset: the Eden temptation has been recreated so that Digory has the opportunity to do right where Adam did not. And this time the temptation is not impersonal as the bell's inscription was impersonal. The Witch tempts Digory with power, wealth and status,

\footnotetext{
${ }^{120}$ Aslan has stated that the worst of the consequences would fall on himself (126), as the reader would know from reading The Lion, the Witch and the Wardrobe.

121 The magnificent bird is not named in this book and is said to be roosting in the tree because it appears to be asleep (147). But in the final iteration of the chronicles, The Last Battle, when all the characters return there, to Aslan's country, the bird is named a phoenix and is awake and gazing at them all (169), perhaps representative of the new life which all of them are now experiencing in the new heaven and new earth.
} 
everlasting youth, and even as a last resort the healing of Digory's terminally ill mother. Yet Digory (not without weakening resolve) does not yield. Digory is able in this context to overcome where Adam succumbed. Lewis has juxtaposed first Adam falling with Second Adam redeeming, Paradise Lost with Paradise Regained.

\section{Second Adams}

Having established Adam's role, Tolkien and Lewis use that context to introduce a Christ (or Second/Last Adam) figure. This figure "must therefore mean primarily remedial or corrective good" for a fallen world (Lewis, The Problem of Pain 85): he cannot just be good, he needs to bring remedy and restoration. Having introduced a fall into a Christian narrative, however defamiliarised, a Christ or a redemption is necessary; there must be one who steps up where Adam stumbled. A Christ-figure brings redemption by giving himself even to the point of death to bring about atonement for a world which bears the consequences of Adam's fall. Many of the key Christological attributes, themes, symbols, and motifs used by Tolkien and Lewis can be found in the first chapter of the gospel of John. One key event is the incarnation: Word becoming flesh, God existing in the form of his creation and dwelling among us (see John 1:14).122 For this reason, it is fitting that Lewis's incarnation of Christ is a lion, as Aslan is the creator of a world of talking beasts. Tolkien defamiliarises further and divides the threefold office of Christ - that of prophet, priest, and king - between three characters: Frodo, Gandalf, and Aragorn. None of these figures is a complete and autonomous Christ: Aslan is a lion not a man, and all of Tolkien's characters are dependent on the actions of their peers. In this way, Tolkien and Lewis extend and complicate the typological mode by creating a different kind of type: not quite an 'Adam', but still a partial version of the incarnate antitype, Christ.

While we have already encountered the idea of a Second Adam in Faramir and Digory, discussed above, it is only Christ who represents fullness of identity: where types can only be partial, Christ alone can fully inhabit dual identities (of God and man ${ }^{123}$ ). Milbank has written on the necessity of duality for the fallen world's redemption. For her, the paradox of duality

122 See also T. A. Shippey, J. R. R. Tolkien: Author of the Century who suggests that Gimli and Legolas "two proverbially soulless creatures [...] are actually discussing (without, of course, being in the slightest aware of it), the Incarnation, the Coming of the Son of Man" (loc. 3777).

123 See Colossians 2:9, "For in him dwelleth all the fulness of the Godhead bodily." The term 'Son of Man', by its simultaneous use and contrast to the other title of 'Son of God' (see John 1:49), hints at Christ's own God/Man duality. George Herbert captures the intersection of Christ's identity as incarnate man and redemptive deity with light imagery: "How neatly doe we give one onely name / To parents issue and the sunnes bright starre! / A sonne is light and fruit; a fruitful flame / Chasing the fathers dimnesse, carried farre" ("The Sonne" 5-8). 'Son of Man' is a term often associated with Christ's earthly life and ministry, his Passion, and his glorious return (Dictionary of Biblical Tradition 725), while 'Son of God' speaks of his heavenly authority and identity. 
proposes some kind of redemption: "It will only be characters who achieve a sometimes grotesque duality of selfhood who will be able to turn the fortunes of Middle-earth [...]. These fissured selves come to embody a sort of paradoxical truth" (99). Milbank here illuminates the reason that both Tolkien and Lewis write only defamiliarised Christ-figures, and not characters who fully embody all Christ's attributes. All of these Christ figures, after all, are mortals who inherit Adam's frailty, and so even Frodo's Passion is the struggle of one who is "half Christ and half Satan" (100): even someone who is "un-Christlike" in his apparently "sinful thrall" to the Ring (99). For Milbank, the "tragic duality of personhood is therefore, with massive irony, the mode in which redemption is gained" (101). The important point is that redemption is possible for these fallen figures. So it is with Frodo, and with Faramir, and with Digory. Even the Christ figures of Aslan, Aragorn and others are all Christlike without being Christ, and that is what makes imaging Christ possible. Milbank writes that Tolkien's work “[admits] a fissure in unitary subjectivity to all its major protagonists" in that "selfhood is revealed to be no longer singular but multiple" (98). This multiple selfhood is especially true of the Christ figures in both Tolkien and Lewis. It is important, therefore, to recognise that the patterning of characters cannot be exact or prescriptive. Although the characters fit their respective moulds to an extent, the forms are also subverted (even through antichrists ${ }^{124}$ ) or incomplete. Such is the nature of defamiliarisation: like and yet unlike. Christ figures who are mortal, and who are created by mortals, bear this kind of duality: where Christ is fully God and fully man, his typological counterparts can only hint at that fullness by portioning out that multiple identity amongst multiple characters.

\section{Lewis's Christ}

While Lewis's Christ figures may be more straightforward than Tolkien's, it is evident that neither he nor Tolkien thought it either possible or appropriate to create a single Christ figure. Several of Lewis's characters have Christlike characteristics - as discussed earlier, Psyche (Till We Have Faces) is sacrificed for a troubled world, and Ransom (Out of the Silent Planet) is given as a symbolic exchange (as his name foreshadows) for the earth - and although each shares in Christ's functions, none aspire to be the single figure. Psyche, for example, does not die, although she is sacrificed, and is moreover better understood as an allegory of the human soul; ${ }^{125}$ it is Cupid (or the God of the Mountain) who is a more traditional Christ figure in

124 Christlikeness for Aslan, for example, is also defined by what it is not, that is, Aslan is offset by his imitators: Shift and Puzzle.

${ }^{125}$ Adey notes that although Psyche "anticipates much that Christ taught and did" in "endur[ing] death" and is "resurrected glowing with life", she was intended to "signify not Christ but the naturally Christian soul" (155). Her name is Psyche after all. 
forgiving her for breaking her vow. Ransom, in his turn, is an unwilling victim, kidnapped to be the ransom for the earth - which turns out to be a misunderstanding, for no such ransom was ever demanded. Although Aslan is recognisable as a Christ figure, Lewis's choice of the figure of a lion is a defamiliarisation worth dwelling on. Aslan's status as a Christ-figure might be too familiar at first glance to admit of being a defamiliarisation at all: indeed, Lewis has turned to Old Testament prophetic imagery for his inspiration, in which the Messiah is described as a lion (see Hosea 5:14). Jesus is also described as the lion of Judah in Revelation 5:5. In characterising Jesus as an actual lion, Lewis defamiliarises by literalising. In this way, his is a more straightforward Christ representation than Tolkien's. It is interesting to note, however, that even while he borrows from the Old Testament, Lewis has not used the more prevalent image of the sacrificial lamb. Christ was, after all, called "the Lamb of God, which taketh away the sin of the world" (John 1:29). Lewis speculates what a Christ would look like if not the man Jesus (see Lewis, Letters to Children 45), so it is worth asking what a lion (an image conveying power and might) contributes to the depiction of Christ as sacrificial bearer of the sins of the world, and how the lion of Judah is better expressed through the figure of a lion itself rather than a man (or indeed a lamb).

What is well known about Aslan is that he dies for the guilt of another and is resurrected. Most adult readers recognise the connection between Aslan and Jesus, but it is important to consider the novelty of Lewis's depiction at the time. In "C. S. Lewis and the Lion: Primitivism and Archetype in the Chronicles of Narnia," written in 1988, Sue Matheson puts it like this: "the Lamb is transformed into the Lion. The irruption of the Lion out of the dead Christian symbol indicates that a new Signature is replacing the old" (15). Perhaps Lewis was aware of the preferences of his audience, and instinctively understood that lions were more appealing than lambs, as anthropomorphic characters go (as Laura Miller,126 the popularity of Rudyard Kipling's The Jungle Book (1894) (though it features a tiger and not a lion), and later Disney film versions of both The Jungle Book $(1967,2016)$ and The Lion King $(1994,2019)$, will testify). Lewis was actually doing something revolutionary for his day: the incarnation of Christ is the divine miracle of God becoming man, yet what Lewis does in his own fiction is remove the human element entirely, for it is not God becoming man, but God becoming beast - something that might almost be blasphemous. Lions are kinglier and more majestic than lambs, as Christ symbols go, and in his choice of the lion figure, Lewis confronts the common, sentimentalised, good shepherd Christ often described in children's books as 'Gentle Jesus, Meek and Mild'; he is leaning instead into an element of power and danger - much like T. S. Eliot's depiction of “Christ

126 Miller, for instance, writes "Children freely and delightedly identify with the characters in animal stories, often more easily than they identify with child characters" (33). 
the tiger" in 'Gerontion' (23). A lion emphasises a Christ with forcefulness, not just a gentle pacifist. In “C. S. Lewis and Christological Prefigurement" (2007), Paul H. Brazier has noted that Christ figures need to have the "humility and weakness" of the "self-emptying God" (750), but also the "power and transcendence" that are just "as much a part of God" (750). The lion of Judah, appearing in the book of Revelation, is furthermore a figure associated with the end of the world and judgement. The sense of the end of the world, a time that will determine damnation or salvation, is relevant for a book set in war-torn Europe. Lewis's defamiliarisation employs Biblical lion archetypes in a way that emphasises the power and authority in traditional understandings of Christ, and explores these unique characteristics outside of a traditional Biblical setting.

What is more, to depict Christ, Lewis has not limited himself to the lion figure in his characterisation of Aslan. It should not be forgotten that as a Christ figure, Aslan also appears in The Voyage of the Dawn Treader as an image in a book, a disembodied voice, a lamb, and even once as an albatross. ${ }^{127}$ Lewis is defamiliarising doctrines, characters, events, institutions. ${ }^{128}$ Being a lion, Aslan troubles the pattern of being the Second Man. Additionally, Kathryn Walls in "An Analogous Adversary: The Old Dispensation in The Lion, the Witch and the Wardrobe" (2017) demonstrates how Lewis's characterisation of Aslan takes its cue from the Israelite lamb-sacrifice in the book of Hebrews: the sacrificial lamb bears striking resemblance to the death of Aslan. Here, both lamb and Aslan are sacrifices, both are bound, meek and unresisting, both are subject to mocking and "shearing as well as slaughter" (205), with the stone table serving as the altar of the Old Dispensation. ${ }^{129}$ This is not (at least not yet) the conquering king that the lion of Revelation describes. In other words, although he is a lion and a Christ figure, Aslan also and perhaps most importantly embodies the part of Old Testament sacrificial lamb the type to which Christ's sacrifice and crucifixion is the antitype. ${ }^{130}$ Having his lion behave as a lamb, the Old Testament sacrificial victim, is Lewis's version of kenosis. As Brazier writes, we must "accept that humility and weakness are as much a part of God as power and transcendence" (750).

\footnotetext{
127 The significance of this might be in the allusion to the cross in its silhouette (143).

${ }^{128}$ For example, Aslan establishes the kingdom in Narnia, through the High King Peter at Cair Paravel, and significantly echoes Jesus's words about establishing the church to the apostle Peter: "thou art Peter, and upon this rock I will build my church" (Matthew 16:18).

${ }^{129}$ It is worth remembering, however, that although Jesus's death was later described in the same terminology as had previously been used to describe the lamb sacrifice (see Hebrews 10:10), his death was, legally and historically, a criminal's trial and punishment.

130 It would be remiss not to point out how the antitype applies to Ransom in Lewis's Space Trilogy. In the first instalment, Out of the Silent Planet (1938), the character Ransom is taken to Mars against his will by two evil scientists, Weston and Devine, to be sacrificially offered to the indigenous inhabitants. The metaphor is a little heavy-handed, as Elwin Ransom is literally made 'to give his life [as] a ransom for many' (see Mark 10:45, Luke 20:28).
} 
What Lewis is doing is quite unique, for Aslan is playing both lion and lamb, embodying both type and antitype. Once he is resurrected and goes on to liberate the captives of the White Witch and win the battle against her and her minions, Aslan becomes the conquering king figure described in Revelation 5. Aslan is, again, both the lamb-like sacrifice (mirroring Christ as the ultimate sacrifice), and the conquering king who comes to judge and rule (mirroring Christ as the lion of Judah in Revelation 5). As Walls puts it, the "Old Testament emerges as foreshadowing the New Testament even while it is displaced by it" (202). Thus, just as Christ's sacrifice fulfils and displaces the sacrificial system of the Old Testament, so Aslan displaces and fulfils the lamb and lion type imagery of the Old Testament in embodying each of those types. Aslan points backwards from the twentieth century to Christ, as even he is displaced by Christ. Lewis has Aslan inhabit all three categories: ${ }^{131}$ he is lion, lamb, and antitypal fulfilment.

\section{Tolkien's Threefold Office}

Tolkien, for his part, bases his characterisations of Christ on quite a different tradition, that of the threefold office of Christ. Thomas Honegger has pointed out that there is a precedent in literature for uniting "legendary, historical and scriptural characters in groups of three" - a theory which would encompass even the Nine of the original Fellowship ("We Don't Need Another Hero" 10). Predominantly a Protestant notion, Ormond Rush explains that the threefold office of Christ, also known as the munus triplex (Rush, "The Offices of Christ"138), was not a prominent part of Catholic theology until the nineteenth century (141). The Catholic Church's Catechism of the Council of Trent, however, which would have been familiar to Tolkien, typifies the offices of Christ as "Prophet, Priest and King" (Catholic Church 35), and the influence of this threefold office is significant for Tolkien's characterisations of his heroes. The concept of Christ's threefold office (though evidenced in Scripture) was first associated with Justin Martyr, Jerome, Peter Chrysologus and Eusebius, who wrote in his Church History:

And we have been told also that certain of the prophets themselves became, by the act of anointing, Christs in type, so that all these have reference to the true Christ, the divinely inspired and heavenly Word, who is the only high priest of all, and the only King of every creature, and the Father's only supreme prophet of prophets. (85)

Biblical scripture contains ample evidence for this priest-prophet-king triad in Jesus (see, for example, Acts 2:22, Hebrews 4:14, and Revelation 19:16).132 In effect, if Christ embodies all

\footnotetext{
${ }^{131}$ All categories equally apply to Christ, but there are differences, such as that Aslan was an actual lion, but the word applied only metaphorically to Christ.

${ }^{132}$ Something of this triplex may even be evidenced at Jesus's birth with the three gifts: gold for kingship, frankincense as the incense of the prayers rising (the office of the priest), and myrrh, which evokes the wine and myrrh Christ was offered at his crucifixion, as the suffering servant (prophet).
} 
three of these offices, then any Old Testament figure who inhabited even one was functioning in some way as a type of Christ - foreshadowing the one who would ultimately fulfil that role. John Henry Newman suggests that Christ's embodiment of this threefold identity represents the Holy Trinity. Tolkien no doubt knew of Newman (though he died in 1890), as his guardian Father Francis was a disciple of Newman's and Tolkien had attended Birmingham Oratory (founded by Newman). Newman suggests that "for in His [Christ's] own proper character He is a priest, and as to His kingdom He has it from the Father, and as to His prophetical office He exercises it by the Spirit. The Father is the King, the Son the Priest, and the Holy Ghost the Prophet" ("Sermon 5. The Three Offices of Christ"). ${ }^{133}$ Newman writes further that

when Christ had thus given a pattern in Himself of such contrary modes of life, and their contrary excellences, all in one, He did not, on His going away, altogether withdraw the wonderful spectacle; but He left behind Him those who should take His place, a ministerial order, who are His representatives and instruments; and they, though earthen vessels, show forth according to their measure these three characters, - the prophetical, priestly, and regal, combining in themselves qualities and functions which, except under the Gospel, are almost incompatible the one with the other. (Newman)

While Newman is speaking of the order of ordained priests, not the universal priesthood of the laity, it would not be too liberal to conceive of every (good) character as participating in the goodness of Christ. Indeed, as my previous chapter asserts, many of Tolkien's characters are described as being on the trajectory towards Christlikeness. As Peter Kreeft writes, "There is no one complete, concrete, visible Christ figure in The Lord of the Rings, like Aslan in Narnia. But Christ is really, though invisibly, present in the whole of The Lord of the Rings" (The Philosophy of Tolkien 222). For these reasons, although there are other Christlike figures, I will focus on Gandalf, Frodo, and Aragorn. Each embodies a separate office of the threefold office, for Tolkien has split this Christlikeness, and divided it up between them.

Yet Tolkien's specific brand of defamiliarisation troubles even these categories. His characters' roles are not distinct but overlap with each others'. While of the three, Aragorn most clearly embodies the role of king, Tolkien's characterisations of Frodo and Gandalf both fit prophet and/or priest. In The Messiah Comes to Middle Earth (2017), Philip Ryken makes a case for Gandalf as prophet, Frodo as priest, and Aragorn as king. It might also be argued, however, that Frodo is the prophet (the one in the wilderness with a difficult message for a deaf world) and Gandalf is priest (he is a point of light and guidance, instructing the Fellowship in what must

133 The history of the threefold office, it must be said, is long and varied and not limited to Newman; however, much of the modern understanding draws on John Calvin and Tolkien was a Catholic. Newman's ideas, we may safely assume, were of the same traditions in which Tolkien had been schooled even if he was not familiar with this particular sermon. 
be done in order to make atonement). ${ }^{134}$ Both interpretations are valid; Tolkien's characters defy easy categorisation. What is more, his Christ-figures are interdependent, and incomplete without each other. Each lacks the full power to defeat evil and win victory for Middle-earth. Although they are each protagonists in their own right, they need the complementary strengths of the others to accomplish their mission. As Honegger puts it, Tolkien highlights "the necessity of a redeeming framework in which a plurality of different types of heroes collaborate towards the greater good"; a framework in which "even hobbits can contribute their share" (13). He calls this "cooperative heroism" ("Splintered Heroes - Heroic Variety and Its Function in The Lord of the Rings" 158). Thus, Tolkien virtually anticipates Milbank's concept of redemption being enacted by dual selves, or in this case, a triplex of characters, people working together to do what Christ accomplished alone. However much these Christlike offices overlap in Tolkien's characterisations of his main trio (itself a kind of a trinity, perhaps?), his defamiliarisation extends not only to extrapolating the offices of Christ to separate characters, but also to blurring the distinctions of the offices themselves. Aragorn's character, as was covered in the previous chapter, is something of a mystery to be riddled through, and so it should not come as a surprise that the offices of Gandalf and Frodo, too, are riddles to be explored. Tolkien is theorising in detail Christ's role in soteriology, and by extension theorising the ongoing influence of Christians, the church in the world.

\section{Priest}

Although Tolkien has fragmented the threefold office, dealing it out between three very distinct characters, there is enough overlap between those roles to make each strange in their distinctly and uniquely Christological function. In some ways, this overlap in definition is in accordance with the difference between the Old Testament and the New Testament concepts of priesthood. In the Old Testament (and in the gospels, during Jesus' time), a priest was a holy figure, an authority of an order set apart in the Israelite community. A priest's main task was to offer instruction and interpretation of holy scripture, and to offer sacrifices for the cleansing and atonement of the Israelites before God (see Leviticus 21). Rush interprets the Biblical office of priest as one of sanctification ("The Offices of Christ"139). After Christ's resurrection, the early church began to re-interpret the role of priest in the light of Christ's priestly offering of himself as sacrifice, so that all believers were named "a royal priesthood, a holy nation" (1 Peter 2:9), and thought to be collectively participant in that special office to receive and pass on the

\footnotetext{
${ }^{134}$ Frodo's priesthood is also alluded to by Aldean Hendrickson in his “True Myth: Tolkien's Catholic Imagination", but his justification for this is Frodo's celibacy (8) - a state which is shared by many of the other characters in the book, including Gandalf.
} 
word of God. In Hebrews 4, Jesus is named "a great high priest" who can "be touched with the feeling of our infirmities; [and] was in all points tempted like we are, yet without sin" (Hebrew $4: 12-15)$. The combination of high priest and sacrifice in Christ, and his empathy for the tempted, causes Ryken to cast Frodo as the priest. As Ryken understands it, "Jesus reconciles us to God, making satisfaction for our sins through the sacrifice of his death" (loc.796). There is certainly a connection to be made between the fire of the altar and Mount Doom, and between the Ring as the sacrifice and Frodo's near-sacrifice. Ryken further defines a priest as a mediator reconciling via sacrifice, an everlasting intercessor, a servant, interdependent in that priesthood of all believers. Indeed, Frodo is reliant on Sam, and others, in the enacting of his own version of priesthood. Yet even as Ryken identifies these characteristics in Frodo, the same might be applied to Gandalf. His sacrifice of himself to the Balrog in Moria for the protection of the Fellowship is also an instance in which Gandalf is himself the beast of sacrifice, descending into fire (The Two Towers 495). Both interpretations are valid if the office of priest is understood in the light of the New Testament.

If the Old Testament concept of priesthood is to be taken into account (and Hebrews $7: 11,15-17$ suggests that it should be), then there is more to be said for the priest's role as one who is set apart from the rest - in a way that Gandalf is, and Frodo is not. Ryken writes that "biblical priesthood was a ministry of sacrifice and prayer, instruction and benediction" (890), which required the priest to make atonement, offer intercession, preach the law, and bless. It is evident that Frodo does not fit this role. Frodo offers service and sacrifice, certainly, but does not preach, instruct, or bless. Those are, however, roles which Gandalf takes on. As the most knowledgeable of the Fellowship, Gandalf guides and supports them with his wizard's powers. Furthermore, Levitical priests were to hold no land, and were scattered throughout the ancient world, supported by the generosity of the other tribes - just as Gandalf finds himself wandering about Middle-earth. Frodo, on the other hand, was not known for his wanderlust (and indeed was very much attached to his home) before the quest for the Ring was foisted upon him. Priests were held in high regard by ancient Israel, being a theocratic nation, just as wizards were "the most influential groups within the nation" (450) of Middle-earth. Indeed, the community of wizards (also known as the Istari or the Maiar) resembles the Old Testament priesthood far more than Frodo's motley circle of hobbit companions does. Gandalf's archetypal appearance of a wizened old man in robes with a staff may well align him to the stereotypical depictions of either priest or prophet. Aaron's priestly garments ${ }^{135}$ suggest further overlapping categorisations between Frodo and Gandalf. Aaron's breastplate, for instance, calls to mind Frodo's mithril shirt that deflects more than one otherwise fatal blow, and Aaron's staff is like 
the one that Gandalf bears. Gandalf's Ring, known as "the Third Ring, Narya the Great" (The Return of the King 1030) or the "Ring of Fire" (1085) is meant to "support [him] in the weariness [he had] taken upon" himself (1085), and has the power to "rekindle hearts in a world that grows chill" (1085). This (like the gems of the twelve tribes on Aaron's breastplate136), is what draws men to him, and unites them to a single cause. Frodo, on the other hand, by virtue of bearing the One Ring, has a more divisive influence.

Narya, the Ring of Fire, moreover, calls to mind Gandalf's art in pyrotechnics and light wielding, in keeping with the Christological light imagery in John's gospel. Gandalf as priest represents the light of guidance and hope. The role of the priest might indeed be described as that of light, in the sense of bringing enlightenment and illuminating scripture, and providing guidance to the Israelites. Psalm 119:105 characterises God's word as "a lamp unto my feet and a light unto my path", and Tolkien has Gandalf's staff literally light the path through the darkness of Moria. In this instance, Tolkien's defamiliarisation represents metaphor in literal terms. Gandalf bears this light metaphorically as well; he is a beacon of hope, always calling others to courage. He does not embody hope himself: he does not bear the Ring to its doom as Frodo does, nor does he return as king to rally and govern the men of the West as does Aragorn. Gandalf's part in the whole is in fact rather indirect (although he does appear at the eleventh hour several times to save other characters from dire circumstances). Gandalf's light represents 'good' in direct contrast to the darkness or blackness of 'evil.' This light is visually represented in Gandalf's "gleaming white" robes as the White Wizard (The Two Towers 494), in his "bright" eyes (494), "piercing as the rays of the sun" (495). Where in the beginning of both The Fellowship of the Ring and The Hobbit, Gandalf's magic may be seen to be no more than a flair for fireworks, it is soon revealed that there is power in this, not just a knack for pyrotechnics. As a wizard, he is capable of magic which he works for the good of the company, either for their entertainment in fireworks, or for their protection in the form of fire. Later, Gandalf's light is the visual representation of stronger enchantments: his smiting the bridge of Khazad-dûm is accompanied by a "blinding sheet of white flame" (The Fellowship of the Ring 331), and both the bridge and his staff break. Gandalf's staff seems to act as a conduit, or at least to represent his power visibly, as Moses's staff was used to command the plagues of Egypt and part the Red Sea. ${ }^{137}$ Later, during the siege of Gondor, it is Gandalf himself who emanates light as "a flash of white and silver coming from the North, like a small star down on the dusky fields" (The Return

136 The priest also carried the Urim and Thummim, items used for divining God's purpose and associated with the gems representing the twelve tribes of Israel upon the priest's breastplate (see Dictionary of Biblical Tradition 803).

${ }^{137}$ As both the speaker of a powerful message of judgement and the purveyor of the law of God (in the tablets containing the Ten Commandments and his word to his people), Moses might also be classed as a figure who trespasses the boundaries of both prophet and priest. 
of the King 809). And in consequence, the world "seemed for a while less dark" (810). From the circle of fire which protects the company from the wolves, to the drawing out of Théoden from the darkness, and the illumination that sends the wraiths from the battle ground, the light Tolkien describes Gandalf as wielding is a force so powerful that it is threat, comfort, protection, guidance, and power. Gandalf has gone from merely brandishing fireworks, to literally becoming a light himself. A parallel can be drawn between the light beacons of Gondor, used to attract help in times of war, and Gandalf who becomes himself such a beacon. Gandalf explains to Pippin that the lights are lit only after the collapse of communication between the Seven Seeing Stones. If, therefore, the beacons were created for such days of disunity, communication blackout, and times of desperation, Gandalf's arrival on Pelennor Fields as light is the same kind of answer to an overcoming darkness. It is also noticeably reminiscent of John 1:9 "That was the true Light, which lighteth every man that cometh into the world," and of the prophecy of Isaiah, who writes: "The people walking in darkness have seen a great light; on those living in the land of deep darkness a light has dawned" (Isaiah 9:2). Tolkien is cleverly layering the imagery: here is Gandalf, a type of Christ, a kind of priest, and a literal source of light.

\section{Prophet}

In the Christological office of the prophet, like that of the priest, there are characteristics which pertain more to Frodo and others which pertain more to Gandalf. This, of all the offices, is the only one which is divinely ordained - a literal calling, as is the case with Samuel (see 1 Samuel 3). Traditionally, according to the Catechism of Trent, the office of prophet is associated with teaching. 138 The connection appears in these words: "Jesus Christ, therefore, was the great Prophet and Teacher, from whom we have learned the will of God and by whom the world has been taught the knowledge of the heavenly Father" (Catechism of Trent 35). The Catechism goes on to call other prophets "His disciples, sent principally to announce the coming of that Prophet who was to save all men" (36), which hints at the definition of prophet as 'one with a message.' Although he does not prophesy in so many words, he does suffer, and so Frodo appears to fit the role of prophet and suffering servant better than he does that of priest. The image of the suffering servant was first given to the prophet Isaiah (53:1-9), but many of the prophets (such as Elijah, Jeremiah, Daniel, and Hosea) have reputations as faithful servants who suffered greatly in the time of their ministry. Frodo's quest to destroy the Ring echoes the song of the suffering servant in Isaiah 53 (a passage which came to be applied to Christ). Isaiah writes, "Surely he hath borne our griefs, and carried our sorrows; yet we did esteem him stricken,

138 See Matthew 21:11, John 4:19, and John 3:2, Luke 18:18. 
smitten of God, and afflicted" (Isaiah 53:4). He "hath poured out his soul unto death: and he was numbered with the transgressors; and he bare the sin of many, and made intercession for the transgressors" (Isaiah 53:12). The evil of the Ring is most apparent to Frodo, who feels its influence more and more, causing him to take on almost Gollum-like traits. Frodo does indeed bear the weight of influencing the future of the Free Peoples of Middle-earth, and that burden does very nearly claim his life. Frodo appears as the one alone in the wilderness who alone understands the true burden of his message given to an earth laid waste, to a land in need of redemption. The hobbits in the Shire have been mostly ignorant of the evil brewing in Middleearth. While other nations have been long engaged in a slow defeat by the Enemy, the Shire has been complacent in its own purity, remaining blissfully unaware of any great changes - thanks to the efforts of Rangers such as Aragorn: "Little do they know of our long labour for the safekeeping of their borders, and yet I grudge it not," the Ranger Halbarad observes (The Fellowship of the Ring 779). Yet the awareness of lurking evil throughout the rest of Middleearth is soon undeniable (and even overtakes the Shire in the end). Frodo alone can testify to the severity of the fate in store for Middle-earth, a fate his fellow hobbits can barely guess at for the major part of the story.

Frodo is furthermore appointed to his role as prophet figure: he receives a kind of "divine call to sacred ministry" (Ryken, loc.215), a hard and difficult task, despite mortal frailty. Following in the footsteps of other reluctant prophets, such as Gideon, Moses, and Jonah, Frodo initially laments his lot - "I wish it need not have happened in my time" (51) - and tries to shift the responsibility on to Gandalf, one he perceives to be better equipped than himself, saying, "I have so little of any of those things [strength and heart and wits]! You are wise and powerful. Will you not take the Ring?" (61). Faramir also later commends Frodo, saying, "If you took this thing on yourself, unwilling, at others' asking, then you have pity and honour from me" (The Two Towers 681). When it is clear that nothing and no-one else will do, however, Frodo accepts the responsibility, though he feels "very small, and very uprooted, and well - desperate" in doing so (The Fellowship of the Ring 62). He comes to understand what Gandalf had said to him at the very beginning: that "there was something else at work, beyond any design of the Ringmaker [...]. In which case you also were meant to have it" (56). He takes up the divine calling, as it were, a heroic trait surely familiar to Tolkien from the traditions of Anglo-Saxon literature. It is clear to Frodo, as it was to Gideon and Jonah, ${ }^{139}$ that no one else will do: the office has already been appointed and has become dependent on the single, elected individual.

139 There are further points of comparison, linking Biblical prophets to Frodo. Gideon, for example, is part of a company that shrinks in number before their final trial; Jonah is sent to a place of great depravity; Isaiah counsels and supports a king against terrible odds. 
Typically, the prophet gives his life to his calling without seeing the fulfilment of his message or ministry; and so here: Frodo feels a sense of hopelessness, and even despairs of success. As his journey draws nearer to Mordor, the burden of bearing the Ring grows upon him: it is "an evil fate," he reflects (The Two Towers 644). So terrible is the suffering of this quest that when finally he and Sam steal into Mordor, way-worn, starving and nearly spent, Frodo says, “It's no worse than I expected. I never hoped to get across. I can't see any hope of it now. But I've still got to do the best I can. At present that is to avoid being captured as long as possible" (The Return of the King 924). He holds to his mission, doomed as it may appear, and stays the course as resolute as ever. This is the mark of such prophets as Jeremiah and John the Baptist, a desperate clinging to their task until the bitter end - until death. Frodo's quest is so difficult that it becomes physical: "his burden was dragging him down" and its weight "had begun to grow once more" (The Two Towers 703); occasionally, it seems even to blind him. Although a Christ-figure, Frodo does not become the sacrifice unto death himself. Rather, it is Gollum who (unwillingly and inadvertently) becomes the life-sacrifice. Frodo manifests instead as the Christ that is the fulfilment of Isaiah's suffering servant (he is called "a man of sorrows, and acquainted with grief" (Isaiah 53:3)), and by his wounds are others healed (see Isaiah 53:5). In carrying the terrible burden of the Ring, Frodo is carrying the weight of the entirety of Middle-earth's evil, and by his suffering, all Middle-earth is saved. Frodo represents the individual who ensures the continued life of the world, where his predecessor Isildur enabled its ruin. Just as Elijah's prophecies came true, and Jonah preached his message and converted an entire nation, the suffering servant may be only an unassuming creature on an unassuming mission, but he is one whose efforts are ultimately vindicated. And so does Frodo accomplish his mission. Tolkien keeps him quite clearly in the position of Christ type rather than antitype, however, in that Frodo does not die as Christ did. Yet the allusions to Frodo's living death (in surviving the Morgul wound) and immortality (in passing to the Grey Havens), exemplify Tolkien's defamiliarising of the resurrection, though Frodo's victory over death (in the destruction of the Ring that would have killed him) is undisguised.

This providential victory against all odds is, as I have discussed above, part of the office of the prophet, suggestive of a divine calling, as opposed to a role for which one is trained. The prophet triumphs through providential aid or supernatural (eucatastrophic) success, against all odds. And a prophet's authority is after all judged by his success. Elijah escapes from the death threats of the powerful queen Jezebel (1 Kings 19); Jonah fails to be killed by the tumult at sea which resulted in his being thrown overboard (Jonah 1). Frodo is not a warrior, and yet he survives what is essentially a world war. Frodo survives dire situations numerous times over the course of his journey, though these escapes do not emanate principally from himself. He 
surprises himself by beginning the assault on the troll in Moria, and survives an otherwise fatal blow because of his hidden mithril armour. He strikes out alone when it becomes apparent that the Fellowship of the Nine can continue no further. He tames Gollum to the point of enlisting him as a guide. He survives the attack of Shelob in her lair (thanks to the efforts of Sam). He does all this, quite apart from surviving the actual quest to destroy the Ring. (Tolkien does not reserve this characteristic especially for Frodo, however, so neither he nor Gandalf can claim this special ability for themselves.)

This unexpected resilience is supposedly characteristic of hobbits and their kind. This makes them almost un-Christlike, in that Christ's role involves death on a cross, and the hobbits, despite weakness and vulnerability, keep surviving. It is significant that it is the hobbits, known for only gardening, eating, and smoking, who manage to divert the ruin of a world. Gandalf says of hobbits that "[y]ou can learn all that there is to know about their ways in a month, and yet after a hundred years they can still surprise you at a pinch" (The Fellowship of the Ring 62). Sam embodies several roles no one would have dreamed up for a simple gardener, and is more than once the hope which revives Frodo at his most despairing. It is Sam who carries Frodo up Mount Doom when his strength fails. "I am learning a lot about Sam Gamgee on this journey," Frodo comments at one point, early in the journey. "First he was a conspirator, now he's a jester. He'll end up by becoming a wizard-or a warrior!" (208). And of course, in a way, Sam does become a warrior. All the hobbits do. Pippin and Merry are notable for their valiant deeds in rallying the Ents to the attack on Isengard. Merry proves a worthy squire of Éowyn, who in her turn succeeds in killing the Witch King. And Pippin, even in his ill-advised venture with the Seeing Stone (an act which destroys the mind and hope of Denethor, the great steward of Gondor), proves to be less damaged than his so-called betters. The Shire hobbits (with the help of these four) succeed in overthrowing the final influence of Saruman, and emerge from the war as the only people of Middle-earth with limited casualties. The hobbits embody an unexpected resilience and resolution for all that they were long considered the least worthy of noble notice. At the very foot of Mount Doom, even as all hope seems gone, a hobbit is invincible:

But even as hope died in Sam, or seemed to die, it was turned to a new strength. Sam's plain hobbit-face grew stern, almost grim, as the will hardened in him, and he felt through all his limbs a thrill, as if he was turning into some creature of stone and steel that neither despair nor weariness nor endless barren miles could subdue. (The Return of the King 934)

The hobbits seem to have a relative immunity to the evils and temptations that beset their betters. They are akin to "the foolish things of the world to put to shame the wise, and God has chosen the weak things of the world to put to shame the things which are mighty" (1 Corinthians 1:27) - like Christ, who was the son of a carpenter (see Mark 6:3). 
It is therefore no accident that Frodo is not special; nothing makes him remarkable. Though Tolkien recreates a pre-Christian world, ${ }^{140}$ he incorporates characters that become Christ-types in that they accomplish Christ's work in the world - but they are never absolutely Christlike. Similarly, he reserves the role of Creator for God only, representing himself as a mere sub-creator. In Middle-earth, therefore, Frodo (and in a lesser way, the other hobbits) are Christ figures only partially embodied. For one thing, the quest is not uniquely Frodo's. As has been discussed, even Frodo's role as prophet has to be shared: with Sam, who bears the Ring for a short time and also bears Frodo up Mount Doom once his strength fails; and even with Gollum, to some extent, who is ultimately the one who carries the Ring down into the fires of Mount Doom. Frodo may embody the office of Christ as a prophetic figure and a suffering servant, but had Gollum not bitten off the finger which wore the Ring and stumbled into the flaming pit, Frodo would have become a second Isildur, another fallen Adam. Frodo bears Adam's frailty, an interdependence, and Christ's prophetic identity all at once.

\section{King}

By comparison, casting Aragorn as king in the third and final role in Tolkien's threefold typology would appear straightforward: he is the eponymous returning king of the third book. As noted in the previous chapter, however, Aragorn's identity is not without its paradoxes and riddles; so also is his status as king. For one thing, his kingship is neither immediately apparent, nor is it taken up until the very end of The Return of the King (1955). Aragorn's kingship, although somehow seeming to be of a higher order than other kings in Middle-earth (the king of Rohan, for example), is not sovereign over all of Middle-earth, or even all Middle-earth peoples (in contrast to 1 Timothy 6:15). Somewhat paradoxically, the mystery of Aragorn's kingship is itself Christlike; it is in keeping with Christ's own 'regal concealment', as the apostle John describes: "He was in the world, and the world was made by him, and the world knew him not" (John 1:10).141 Verlyn Flieger has similarly noted that "obscurity until the right moment" is also the mark of "the medieval hero pattern" ("Frodo and Aragorn: The Concept of the Hero" 128). Although the gospel narratives define themselves as accounts of Jesus as 'Messiah', 'King', and 'Christ' (see Matthew 1:1, Mark 1:1, Luke 1:31-33 and John 1:34), Jesus's identity is only gradually understood as such. In fact, Ryken writes that the king's concealment is "partly by design" until the time comes for him to confront evil "and claim his rightful kingdom" (Ryken,

140 Tolkien, in an interview with Charlotte and Denis Plimmer, famously exclaimed: "Of course God is in The Lord of the Rings. The period was pre-Christian, but it was a monotheistic world" (Plimmer et al. 35). ${ }^{141}$ Jesus did not fully take on the role of king in his adult life, though the Magi did name him "he that is born King of the Jews" (Matthew 2:2). The title of king was only sardonically attributed to him - see Matthew 27:11 and John 19:19. 
loc.1472). Thus, when Rush interprets the office of kingship to be one that is to do with governance (Rush 151), but also as a role which is pastoral (139), we see Aragorn inhabiting his kingship in the guidance and care he gives the Fellowship long before his identity as sovereign is acknowledged. Even in his fissured identity of wanderer-or-king, Aragorn images Christ.

According to John Henry Newman, the office of king requires sovereignty over death in addition to the role of king as conqueror. He summarises Christ's kingly office as that of "a conqueror, and a king, in rising from the dead, in ascending into heaven, in sending down the Spirit of grace, in converting the nations and in forming his Church to receive and rule them" ("The Three Offices of Christ"). The king as conqueror is expected to be conqueror over death. ${ }^{142}$ Through Aragorn, Tolkien fully takes up the associations of Christ as king over death, and Christ as life, as expressed in John's gospel. After the battle on the Pelennor fields, he steals into the city of Gondor (not yet in his role as its rightful king) to heal the wounded and dying. Aragorn brings life. He identifies himself thus: "I am Elessar, the Elfstone, and the Envinyatar, the 'Renewer'” (863). He has already proven equal to the task of renewing Frodo after "a deadly wound" from the Witch King on Weathertop (The Fellowship of the Ring 197). In tending to Faramir, described as "nearly spent" (The Return of the King 864), Aragorn seems close to giving his own life in the saving of another. Aragorn tends to him as if in "some great struggle" (865), his face greys in weariness and he calls Faramir's name ever more faintly, "as if Aragorn himself was removed from them, and walked afar in some dark vale, calling for one that was lost" (865). And yet the life of Aragorn proves more powerful than death, which must loosen its hold on Faramir. The restoration is described in imagery of rebirth and life: the spectators have an impression "like a memory of dewy mornings of unshadowed sun in some land of which the fair world in spring is itself but a fleeting memory. But Aragorn stood up as one refreshed" (865), where mere moments before his face seemed to foretell of his own death. Gandalf later explains to Frodo and Sam (also revived by Aragorn), "[t]he hands of the King are hands of healing [....] But you were on the very brink of death ere he recalled you" (956). The healing king is also a staple of medieval myths - there are stories, for example, of Arthur healing. Aragorn's version of kingship has authority over life and death - even to the point of being miraculous. Aragorn's kingship means healing - a reputation for which Jesus shared (see Matthew 11:5). Thus, characterising a Christlike king, Tolkien images an interpretation of Christ's ministry of healing and life.

\footnotetext{
142 Interestingly, it is an association that has also been made by the poet George Herbert in his poem about the priest "Aaron" where he describes the vestments of Aaron: "Holinesse on the head, / Light and perfections on the breast, / Harmonious bells below, raising the dead" (1l. 1-3).
} 
Finally, although Gandalf and Frodo each pass through a kind of resurrection, it is in Aragorn that Tolkien captures the essence of Christ's mastery over death (see Romans 6:9: "death hath no more dominion over him"). It is true Frodo has a mortal wound, and Gandalf experiences something very like a resurrection after he does battle with the Balrog - however, whatever he undergoes at that time, Tolkien always stops short of using the word 'death' or 'dying' to describe it. Aragorn, though he does not die, 'passes through' the Paths of the Dead, and shows himself to be master of the dead. When Aragorn determines to walk the cursed path into Dunharrow and Erech in The Return of the King, his comrades in arms believe it will mean his death. Éomer assumes "it is little likely that we shall ever meet again under the Sun", for it is well known that "no living man may pass" that way (779). ${ }^{143}$ It is the place of the Sleepless Dead, cursed by a broken oath to Isildur, Aragorn's ancestor. Far from suggesting that death is the dominant force, this episode endorses the opposite: not that "[the dead] do not suffer the living to pass" (783), but that Aragorn, the living, does not suffer the dead to remain so. Aragorn invokes the oath that was broken, as only the rightful heir can, and so the Dead follow him (see 2 Corinthians 4:14). "No other Men could have endured it," Tolkien assures the reader (790), yet Aragorn passes through, and "out of the Paths of the Dead" (847). Gimli wonderingly observes that "[e]ven the shades of Men are obedient to his will" (875). This phrasing is deliberately reminiscent of the disciples' reaction to the miracles of Christ as they began to understand his purpose and deity: "They were terrified and asked each other, 'Who is this? Even the wind and the waves obey him!'” (Mark 4:41) - powerfully associating Aragorn with Messianic imagery. At his command, the armies of the Dead lay waste the forces of Sauron. Far from succumbing to death by this course, Aragorn commands the Dead, driving and directing their power to kill others. It is already noteworthy in Aragorn's status as a Christ figure that he has passed through death as it were, being completely untouched by its influence ${ }^{144}$ - but, over and above this he masters it and subdues it to his own will.

Of the three offices, the office of king in Aragorn is reasonably straightforward: the kingship role is easiest to categorise of the triplex because the offices of prophet and priest are less clearly defined and demonstrably more ambiguous. Moreover, it is possible to have many priests and/or prophets at any given time, but only one king, so the office of king is usually clear. It is worth noting even so the token ways that Tolkien has Aragorn fail to take up his office, or indeed trespass into the territory of the other offices. Before he takes up his mantle as Isildur's heir, Aragorn plays many parts: Ranger, leader of the Nine, tracker, warrior, negotiator,

${ }^{143}$ However, a seer who had predicted his path hinted at an opposite outcome: "to the tombs of kings / doom approaches. The Dead awaken; for the hour has come for the oathbreakers" (781).

144 There is a connection to be made between Aragorn passing through the Paths of the Dead, and the idea of the harrowing of Hell (see 1 Peter 3:19-20 and Revelation 1:18). 
captain, oath-invoker, healer, and the "Enemy of Sauron" (The Return of the King 971). His kingliness is something he must grow into, emerging gradually over time, occasionally surprising his companions (although, as I have said, regal concealment is a quality of Christlikeness). When he receives the brooch from Galadriel, "those who saw him wondered; for they had not marked before how tall and kingly he stood, and it seemed to them that many years of toil had fallen from his shoulders" (The Fellowship of the Ring 375). These occasions occur more and more frequently as Aragorn approaches his destiny, with observers catching "brief vision[s] of the power and majesty of the kings of stone" in his living face (The Two Towers 433) - visions powerful enough to make the attacking hoards at Helm's Deep pause at the onset of battle (see 540). Despite his increasingly obvious kingship, Aragorn does occasionally show prophetic or priestly attributes. It is quite remarkable that while raising the dead is a miraculous power for which Old Testament prophets are particularly known, neither Frodo nor Gandalf seem to heal or raise to life as prophets (though they themselves go through different kinds of resurrection). Aragorn foretells Gandalf's doom (should he pass through Moria), thereby trespassing into the realm of a seer or prophet. After Gandalf falls to the Balrog, Aragorn laments "Farewell Gandalf [...] Did I not say to you: ifyou pass the doors of Moria, beware? Alas that I spoke true!" (333). Similarly, when guiding the hobbits to Elrond, and later tracking the Uruk-hai who captured Pippin and Merry, Aragorn demonstrates great skill in tracking and guiding his company, as Gandalf often does (and as Moses does for the Israelites through the desert). Aragorn's knowledge is second only to Gandalf's and the unfolding of secret mysteries (as part of the priestly office) often falls to his lot. Although king, Aragorn's inhabiting of the role is only partial for most of the text, defamiliarised constantly throughout his journey. He does not behave as one would expect a returning king to behave (especially when contrasted with Boromir, the lord of Gondor and his hunger for great deeds and glory). Tolkien keeps Aragorn's kingly identity at arm's length. The partial embodiments of these Christological offices point to the necessity of a single figure who can embody all. Through these Christ characters, Tolkien is exploring the depths of meaning in individual attributes of Christ.

\section{Conclusion}

Tolkien and Lewis link the Christ of the Bible with characters in their fictions, but even as they employ Adam and Christ types, they just as often subvert typological categories. Many of their Adam-like characters are presented to the reader in a sympathetic light; we appreciate that their temptations might have been ours. Adam's actions require a Second Adam to act as Christ and remedy the effects of his fall. 
Tolkien and Lewis defamiliarise types and antitypes of Christ in order to imagine the salvific arc which connects the first man to the Second Adam. Yet, as emphasised above, these types and antitypes prove to be overlapping or flawed examples of patterns they only partially embody. Both authors reserve the completeness of the incarnate God for Christ. John Henry Newman has written, "The world was like some fair mirror, broken in pieces, and giving back no one uniform image of its Maker. But He came to combine what was dissipated, to recast what was shattered in Himself" ("The Three Offices of Christ"). This is an idea that Tolkien has echoed in his poem 'Mythopoeia': we only see in "mirrored truth the likeness of the True" (ln. 134); man is only "refracted light" and "splintered from a single White" (62-63). Tolkien and Lewis are not recreating Biblical types (like Abraham and Moses) so much as adding their own Christ types by defamiliarising Christ. They are 'splintering light' from the 'Single White' by making strange the mould of Christlikeness in order to re-accentuate the character of Christ himself. 


\section{Chapter Four: Death and Endings (and Beginnings)}

Verily, verily, I say unto you, except a corn of wheat fall into the ground and die, it abideth alone: but if it die, it bringeth forth much fruit. (John 12:24)

Death is a crucial thematic touchstone in all fantasy literature: many of the driving forces of both good and evil in this literature revolve around saving characters or worlds from death, or cheating it. In her thesis "Intimations of Mortality", Angelina Sbroma argues that mortality in children's fantasy fiction in particular is "so persistent [...] that it becomes unremarkable" (3). In fantasy fiction, the concept of death is especially fascinating, as authors are free to treat death what it means and where it leads - very creatively, almost to invent it. Death in the fantasy novel is where all the ideology of the story comes together with the reader's longing and empathetic experience to acknowledge what Amy Amendt-Raduege, in 'The Sweet and the Bitter': Death and Dying in J. R. R. Tolkien's The Lord of the Rings (2018), calls “an innate human need to make death mean something" (3). In this final chapter, it is fitting to explore how Tolkien and Lewis defamiliarise the concept of endings, particularly death itself.

That death is a recurrent theme in the fiction of Tolkien and Lewis hardly needs elaboration. Throughout the fiction of Tolkien, death is a presence almost tangible: there is an overhanging doom because what threatens is not just individual death, but tribal and national indeed, the death of a world. In The Hobbit, Thorin describes his quest to Bilbo as "a journey from which some of us [...] may never return" (29). Thorin is more than willing to take life, or give his own, for the quest. The Lord of the Rings is a war-quest story, avowedly about "Death and Immortality" (Letters 246), with many characters killed in clashes with the enemy, ${ }^{145}$ and the rest of them facing death explicitly at some point. Other stories by Tolkien have a sheen of nostalgia, dealing with myths of those long dead. Many of Lewis's Narnian books similarly deal with the threat of death in battle. The final instalment, The Last Battle, which Lionel Adey declares "shows Lewis at his best and worst as a storyteller" (C. S. Lewis: Writer, Dreamer, and Mentor 180), includes the deaths of all the main characters (notably excluding Susan) as well as the death of the world (Narnia, at least). Tolkien's "Leaf by Niggle" (1945) and Lewis's The Great Divorce (1945) both deal explicitly with the hereafter. As William Gray has pointed out, a wellwritten depiction of death can be almost evangelical ("Death and Fantasy" 5), and both authors are well aware of how death is used in fiction, in their own writing, and in the work of authors

${ }^{145}$ Amendt-Raduege puts the number at over fifty of the named characters (7), but few of the central characters, such as Boromir, Denethor, Gollum, Saruman, and Wormtongue. 
they admired, particularly Chesterton (2). Although a persistent and weighty theme, death in their fiction touches on resurrection, renewal, or rebirth: not just in terms of some sense of 'heaven' or a 'beyond,' as with the reborn Caspian, but in the actual second lives of Gandalf, Aragorn, and Aslan.

Christian doctrine teaches that death has already been conquered through the death of Christ ("whosoever believeth in him [the Son] should not perish, but have everlasting life" (John 3:16)). I do not mean to imply that Christ removed the reality of individual death; instead Christ has conquered death in the sense that it no longer condemns humanity to eternal punishment or extinction. Death is no longer final; instead it becomes a transition to new planes of existence. Tolkien and Lewis, taking their cue from this very 'familiar' doctrine, turn endings into beginnings in their own narratives, and their very distinctively Biblical eschatology guides the defamiliarisation of death and endings along very specific doctrinal courses. The paradox being explored is that the end is not the end. In keeping with defamiliarisation's mode of operating, Tolkien and Lewis have made deliberate attempts to keep even their narratives open-ended. Their eschatology guides the defamiliarisation of death and endings along very specific doctrinal courses. The crux of Christian theology is the death and resurrection of the incarnate Christ, after all. Whereas in the previous chapter the arc of the Fall narrative was described in terms of characters, and Adam and Christ characters, this chapter considers the Fall more holistically: it explores death as the idea of redemption, the possible regaining of an unfallen state. In this way, Tolkien and Lewis push the reader to imagine beyond endings, even those of their own narratives.

Aslan's death and resurrection in The Lion, the Witch and the Wardrobe is an apt illustration of how death can be aesthetically defamiliarised. It contains a layer of conceptual (not just poetic) defamiliarisation, as discussed in a previous chapter: Christian doctrines of death incorporate notions of resurrection and Heaven in their implication that death is not death but rather a new beginning. Aslan's resurrection clearly parallels the Gospel accounts, but Lewis has made very deliberate changes. To begin with the parallels: first there are the watching women, represented by Susan and Lucy who tearfully observe the whole of the death scene (The Lion, the Witch and the Wardrobe 140-41) just as the women did at the foot of the cross (see Matthew 27:55-56, Mark 15:40, Luke 23:49, and John 19:25). The women are the ones who visit the tomb, and who are the first witnesses of the resurrected body, just as Susan and Lucy stay with the body of Aslan, removing the bonds that the mice gnaw through. In both the Gospels and The Lion, the Witch and the Wardrobe, the actual resurrection is not witnessed. It takes place 'off-stage', as it were: Jesus is resurrected within the tomb, and Aslan is resurrected while the girls have their backs turned (146). The depiction of Aslan's resurrection 
emphasises his corporeality: his breath, his smell, and his touch when he licks Susan's forehead (147). This last recalls Christ's invitation to Thomas to touch him (see John 20:27).

But there are many differences: Aslan may be an incarnate version of a deity, but he is incarnate as a lion. Lewis has Aslan really act his 'lion-ness' in his resurrected body. His mane has grown back, after being shorn off some hours before. He roars, he romps, he plays, he has Susan and Lucy chase his tail (148). Aslan's part in the story, moreover, is shortened (in comparison to Christ's three-year ministry; though it is a return to Narnia after a long absence, it is not a Second Coming either): Aslan establishes his 'church' in putting Peter in charge of the army and Cair Paravel (119) and goes immediately away. Aslan's mission is still unfinished at the time of his death and resurrection - he still has a battle to fight and captives to free. In contrast, although the risen Christ appeared to his disciples (to validate reports of his resurrection), his time amongst them was effectively over. There are prophecies concerning the Second Coming of Christ and his final act gathering his people to himself, including raising the dead (see 1 Thessalonians 4:16-17, Hebrews 9:28). The reader does not, however, mistake Aslan's freeing of the captives for that kind of Second Coming. Lewis again troubles the clear distinction between the Creator (returned after the events of The Magician's Nephew) and the incarnate Christ here. Instead, Lewis reverses his terms: rather than longing for the second coming of Aslan, the reader longs for the children to come back to Narnia to be with him. Lewis's departures from traditional depictions of the resurrection, especially the intensifying of the lion aspect demonstrate his determination and commitment to defamiliarising the episode. There are many differing schools of thought amongst Christian theologians about life after death, and when Tolkien and Lewis depict Christian death and resurrection, they join the ranks of other believers who theorise. For Tolkien and Lewis, this theorising takes the form of imaginatively re-conceptualising the Christian tradition: they defamiliarise their fictional representations from the forms and patterns put forward in the Bible.

\section{Death and the Fall}

\section{Death as Sacrifice}

The resurrection of Christ in Christian theology emerges out of his embracing sacrificial death. This of course is not exclusively a Christian notion, and has a number of pre-Christian, pagan antecedents, of which both Tolkien and Lewis would have been aware. Throughout his books, Tolkien's characters frequently mirror the Christlike concept of "Greater love hath no man than this, that a man lay down his life for his friends" (John 15:13), especially in battles and other warlike scenarios. One well-known example from The Fellowship of the Ring is at the 
bridge of Khazad-dûm in Moria, where Gandalf sends the Fellowship over the bridge that spans a chasm, and plants himself in the middle, barring the way of the Balrog's pursuit. Gandalf succeeds in breaking the bridge beneath it, but the Balrog manages to snatch him away as it falls. The goblin drums speak as portents, dying away behind the fleeing company: "Doom, doom" (332). But the doom does die away: the Balrog is vanquished, and even Gandalf's doom is short-lived as he later returns to life. Tolkien valorises life-giving acts. Even though Aragorn and Boromir did turn to help him (to no avail), Gandalf tells the Fellowship, "This is a foe beyond any of you. I must hold the narrow way" (330). And although Gandalf does not know that the breaking of the bridge will lead to his own death, he is nevertheless depicted as heroic in his putting himself in the way of death, in fighting the Balrog at all while the others escaped. At the very end of his life, Boromir does the same, but Boromir at least understands that his life will be forfeit. In this kind of sacrifice, Tolkien hints at the doctrine on which the sacrificial system depends, that the sacrifice of one can be the salvation of many.

Lewis's handling of sacrificial death, as already intimated above, is deeply influenced by the doctrine of atonement (see Hebrews 9:22: "And almost all things are by the law purged with blood; and without shedding of blood is no remission"). As Kathryn Walls writes, "Although Aslan's death parallels the Crucifixion, Lewis is not concerned with the Crucifixion as such. He is concerned, rather, with the doctrine that (to his mind) made sense of it" ("An Analogous Adversary: The Old Dispensation in The Lion, the Witch and the Wardrobe" 213). The doctrine of the Jewish sacrificial system strongly featured substitutional sacrifice (often of a lamb on behalf of humanity) to achieve atonement. This is the kind of Christlike sacrifice that Aslan makes for Edmund in The Lion, the Witch, and the Wardrobe (as other scholars have noted ${ }^{146}$ ), with Aslan taking on the role of both an antitype for the lamb of sacrifice and as a substitute for sinful humanity. It is a case not just of the lion lying down with the lamb but being the lamb. Lewis articulates the power of substitutional sacrifice when the resurrected Aslan explains:

"[T]hough the Witch knew the Deep Magic, there is a magic deeper still which she did not know. Her knowledge goes back only to the dawn of time. But if she could have looked a little further back, [...] she would have read a different incantation. She would have known that when a willing victim who had committed no treachery was killed in a traitor's stead, the Table would crack and Death itself would start working backwards" (The Lion, the Witch and the Wardrobe 148).

146 For example, Jay Ruud's “Aslan's Sacrifice and the Doctrine of Atonement in The Lion, the Witch and the Wardrobe" (2001). 
Aslan seems to suggest here that the Deeper Magic is a universal rule by which all worlds and magic are governed, and that such a sacrifice has the power to turn death backwards. ${ }^{147}$ So indeed it seems to, as Aslan goes on to restore to life creatures that the Witch turned to stone. Milbank states that when Christ comes back to life, Satan "loses all of his other human debtors" (Chesterton and Tolkien as Theologians 106). Aslan's Messianic sacrifice "sanctifie[s] through the offering of the body [...] once for all" (Hebrews 10:10), so that the Witch, on sacrificing this particular one, loses all others. Aslan's sacrifice (and resurrection) restores them to life.

Both Narnia and the Jewish sacrificial system are deeply rooted in and bound by this system of atonement: Edmund, declares the Witch, "belongs to [her] as [her] lawful prey" (The Lion, the Witch and the Wardrobe 128). His blood is her property: his life is forfeit to her (129). Aslan confirms her claim: "unless [she has] blood as the Law says all Narnia will be overturned and perish in fire and water" (129). The Old Testament law of sacrifice is founded upon death mortality is part of the curse placed on Adam (see Genesis 19:9). Lewis has made this law literal, embodied it so that there is a literal person demanding the blood of a transgressor. The apostle Paul explains that the "letter" of the law (the old covenant of sacrifice) "killeth,"148 and "the spirit" of the law (the atonement of Christ) "giveth life" (2 Corinthians 3:6). The Witch personifies Death as the letter of the law. Walls has also noted the close relationship between the Witch as a personification of the Old Testament law of Death, and "Synagoga" as the Old Testament law which condemns man (206). Lewis makes a fascinating theological statement by having the Witch named "the Emperor's hangman"149 (The Lion, the Witch and the Wardrobe 128). The Witch claims her due, but is subject to a greater authority. She answers to the Deep Magic, just as Death is answerable to God in Lewis's theology. In this way, Lewis conceptually separates Death from God. Transgression is treated as a debt to be repaid (through sacrifice). Rather than portraying a vengeful God who metes out capital punishment for crimes, Lewis defamiliarises the letter of the law into an enemy who must be overthrown: the demand for sacrifice is no longer associated with the God-figure, but with an admittedly cutthroat wicked witch, who can be dealt with separately. Aslan's resurrection, moreover, nullifies the role of a hangman altogether (perhaps sanitising God of death-dealing associations for young children). Where the Deep Magic had threatened death, deeper magic overcomes it and brings life.

147 This Deep and 'Deeper' magic is a trope evident in other fantasies, too. J. K. Rowling's Harry Potter books come to mind, where the love of Harry's mother in dying for him has a mysterious power, stronger even than the power of Lord Voldemort in attempting to kill him.

148 Lewis's Stone Table, on which Aslan is sacrificed, and which is "cut all over with strange lines and figures that might be the letters of an unknown language" (The Lion, the Witch and the Wardrobe 115), elegantly symbolises the 'letter of the law' here.

149 The Emperor is Lewis's unseen God-figure. As Aslan is the "son of the great Emperor-beyond-the-sea" (75), this is a clear nod to Christ as the Son of God, the "the image of the invisible God" (Colossians 1:15). 
In The Lion, the Witch and the Wardrobe, while Lewis examines and portrays the theology of atonement, the ethics of sacrifice itself are largely unquestioned. This changes in Till We Have Faces (1956), in which Lewis confronts the idea of sacrifice by writing of sacrifice to a god whose demands for blood appear gratuitous. Although Lewis champions the doctrine of atoning sacrifice in several of his theological musings, his portrayal of Ungit sacrifices reflect a noticeable departure from his sanitised tone, particularly in its gruesome and gory detail. Orual, the narrator, observes:

I think that what frightened me (in those early days) was the holiness of the smell that hung about [the Priest of Ungit] - a temple-smell of blood (mostly pigeons' blood, but he had sacrificed men too) and burnt fat and singed hair and wine and stale incense. It is the Ungit smell. (19)

This is a far cry from the nobility of Aslan's selfless sacrifice in The Lion, the Witch and the Wardrobe (a relatively bloodless death if not entirely palatable). A. N. Wilson's observation is apt when he says that in later years Lewis began "to glimpse both the incomprehensibility and the challenge of his faith" (C. S. Lewis: A Biography loc. 4892), and the evidence of it is reflected in his fiction. Perhaps the familiarity Lewis aims to dislodge here is not that of non-believers, but rather the oversimplified imagination of the Christian believer, whose version of sacrifice might easily gloss over gore, including the gore of a Roman crucifixion. ${ }^{150}$ In its ambivalence, Lewis's fiction grapples with the complexity of a notion of God who is loving and gentle, but also fearsome and powerful - a dichotomy he attempted to illustrate by imagining Christ as a lion:151 a talking animal who appeals to a child's love for talking animals, but also an animal capable of killing. All the same, a lion, even a wild lion, is not so provocatively formidable as the bloody Ungit. Orual explains matter-of-factly (as a resident of that country and practitioner of the Ungit religion might) that the ubiquitous and gory sacrifices include human beings. While Lewis's descriptions of ritual sacrifices are no grislier than certain Old Testament passages, ${ }^{152}$ he is careful to distance Ungit sacrifice from reverence, or 'holy fear'. The Priest's smell is associated with uncanny horror, and the reader perceives Orual's aversion to the bloodiness of it. Lewis

150 There is evidence even Mrs Moore regarded Lewis's religious ritual with some horror. Wilson records she "resented" his conversion, "chiding him when he resumed the practice of Holy Communion for attending 'blood feasts'” (loc. 2365).

151 The Narnians keep saying that "He's wild, you know. Not like a tame lion" (The Lion, the Witch and the Wardrobe 166). Mrs Beaver reckons that "if there's anyone who can appear before Aslan without their knees knocking, they're braver than most or else just silly" (75), and Lewis explains to the reader a little later that "People who have not been to Narnia sometimes think that a thing cannot be good and terrible at the same time. If the children had ever thought so, they were cured of it now" (117).

152 See Leviticus 1-5: many of the offerings involved the slaughter of livestock or doves, often accompanied by splashing blood on the sides of the altar $(1: 5,3: 2,7: 2)$, applied to the right ear lobe, thumb, and big toe of the priest (8:22-24, 14:12-18), or sprinkled in front of the sanctuary and applied to the horns of the incense altar $(4: 3,6-7,17-18)$. For some sacrifices the flesh was burnt on the altar, and for some others, a portion of the sacrifice was consumed. 
intends the reader to consider sacrifice as something brutal, barbaric, gratuitous, unpalatable. This is a sacrificial system which demands life, but which is without atonement or redemption. On the one hand, the sacrifices caused no discernible intervention for Psyche's dying mother they avail no more than the "smell of slaughtering and blood on the floor" (Till We Have Faces 22). On the other hand, when Psyche is herself sacrificed to save the country from drought and sickness (although she escapes what everyone assumes to be a sacrifice unto death), the curse is lifted. In writing for an adult audience Lewis is no longer writing neat atonements, like that of Aslan's for Edmund, perhaps because he realises that theories of atonement are not inherently neat.

Although Psyche's near-death self-sacrifice more than once saves them all in the face of a national crisis, the atonement her sacrifice buys is not quite sufficient. When it is rumoured that Psyche's hands have healing power, she nearly spends herself in caring for those afflicted with fever. Her sister Orual expresses concern that Psyche will die of exhaustion if she does not stop, and the heartless King replies, "Then more's the pity [....] They'll kill us all if she stops" (41). Although distinct from the sacrificial system first described as service to Ungit, there is foreshadowing in the king's words, a suggestion that life can be bought by the giving of another life. Psyche's sacrifice is later made explicit. In order to pacify Ungit, a victim must be sacrificed to the Brute, Ungit's son. The victim must be sent to die in the "rite of the Great Offering" (54) (or to become his bride; the Priest is vague). No mere animal, or even unwanted human (prisoner of war or thief) will now satisfy Ungit; it must be the "best in the land" (57), and Psyche is chosen. The king, overwhelmed with relief that the lot does not fall on him, is quickly convinced: "Ungit must have her due. What's one girl - why, what would one man be - against the safety of us all? It's only sense that one should die for many. It happens in every battle" (69). This phrasing mimics that of Caiaphas who unwittingly prophesies the work Jesus's death would accomplish: "it is expedient for us, that one man should die for the people, and that the whole nation perish not" (John 11:50). Despite coming from both Caiaphas and the King, this is an eloquent expression of sacrifice, of the wagering of a single life for the salvation of many. The difference is in intention and motive. Even though Ungit has a history of caprice, the bargain is clear, and so the sacrifice is made. Adey writes that "[j] ust how the sacrifice relieves Glome of pestilence and famine is not clear" (155). The drought lifts, the impending war is defused, and all fortunes are turned - and yet the apparent success of Psyche's sacrifice rings a little hollow: The rain comes too late for the crops, though there is enough grass to save the cattle from starvation; Orual is smitten with a severe illness, though the fever is finished. The Fox, an advisor in the court who is not prone to believe in mysteries or deities, puts it all down to chance. He explains that changed winds were already travelling the thousands of miles from the 
coast long before Psyche's sacrifice. Later, when it is revealed that Psyche is not in fact dead but has been taken up as bride by the mysterious god, the idea of sacrificial death is rendered even more irrelevant. Even as Lewis foregrounds an atoning sacrifice, he completely defamiliarises and problematises it by stripping it of its power and function, not least by locating its theoretical justification in the words of a corrupt king, concerned only for his own selfish interests. Lewis allows discomfort with a sacrificial system to pervade the text, implying that the sacrificial system cannot adequately address the problems it purports to resolve. In Till We Have Faces, Lewis thus sets the stage for something greater, a more complete solution, a deeper magic.

\section{Death as Fallenness}

As established earlier in this thesis, in their depiction of a theology of fallenness and death in their invented worlds, Tolkien and Lewis simultaneously anticipate the regaining of an unfallen state, characterised by life. Tolkien's Elves, for example, testify to this unfallen state: though they can be slain or die of sorrow, they are immune to time and disease, and their natural immortality makes death unnatural to them. ${ }^{153}$ Tolkien depicts the redemption arc in pastoral terms. He takes his cue from Genesis 3 which prophesies a 'cursed earth': instead of yielding to cultivation and beauty, life and abundance, the land itself portends "painful toil" (3:17) and "thorns and thistles" (3:18). In The Hobbit, the spreading influence of evil is particularly noticeable in the growing gloom of the forest of Mirkwood, itself conspicuously fallen from the glory of Elf-occupied woods such as Lothlórien, though there are some Elves who live there. Like Milton before him, Tolkien appears to be drawing on the idea from Romans 8:22, that all creation is groaning in anticipation of redemption, as if creation itself was wounded in some way by the Fall. The journey through Mirkwood is described as "dark, dangerous and difficult" (The Hobbit 133), a place where the "the wild things are dark, queer, savage" (133).

The natural world in The Hobbit is not only corrupted, but seems eventually to take an active role in its own fallenness. The logic is reminiscent of that of the folk tale in which the child who eats the monster's food becomes ill and eventually transforms into a monster himself. So Mirkwood equally suffers and then becomes the poison which causes its trees to become twisted and gnarled, that drives away living things, that keeps it "everlastingly still and dark and stuffy"

153 This in itself is an interesting defamiliarisation, in that it depicts fallen creatures coexisting in the same world as unfallen ones. In Splintered Light: Logos and Language in Tolkien's World (1983), Verlyn Flieger suggests Tolkien makes this contrast- that of men dying and leaving the world where Elves do not (51) deliberately, because the separate peoples better image the paradoxical "need for the world and the need to leave it" (110). Tolkien himself characterises elven immortality as "the mystery of the love of the world in the hearts of a race 'doomed' not to leave it, until its whole evil-aroused story is complete" (Letters 246). 
(141), and that turns its river black with enchantments. It gives the impression of land that is diseased, writhing, menacing. The trees' "trunks were huge and gnarled, their branches twisted, their leaves were dark and long. Ivy grew on them and trailed along the ground" (136). They take on a threatening personhood almost, looming, watching, reaching - Mirkwood is a place where "it had seemed as dark in there in the morning as at night, and very secret: [having] 'a sort of watching and waiting feeling"' (137). The menace of the wood is not limited to a general atmosphere of evil, but its hostility to all living things: Bilbo observes as they approach that "[b]irds began to sing less. There were no more deer" (136). The journey through is prohibitive and the company gradually loses access to food and water, light, air, and eventually the path altogether. At its darkest centre, where dwell the cluster of giant spiders, it is as if the forest is united with the spiders and their treacherous webs as a single terrible entity: Bilbo describes it as "a place of dense shadow [...] black even for that forest, like a patch of midnight that had never been cleared away" (155). Havoc has been wrought on all the living things: they are corrupted and distorted, and they themselves corrupt and distort.

In contrast to Tolkien, Lewis's depiction of fallenness manifests itself more in human nature, reflecting a decline from 'good' Creation, as in Genesis. In The Magician's Nephew, for example, we see a steady deterioration in the Hall of Images where the monarchy (including the Witch) is magically preserved, like a procession of "the most wonderful waxworks you ever saw" (47). Most compelling to Digory is the progression of evil manifested in the faces:
All the faces they could see were certainly nice. Both the men and women looked kind and wise, and they seemed to come of a handsome race. But after the children had gone a few steps down the room they came to faces that looked a little different. These were very solemn faces. [...] When they had gone a little further, they found themselves among faces they didn't like [...] The faces here looked very strong and proud and happy, but they looked cruel. A littler further on they looked crueller. Further on again, they were still cruel but they no longer looked happy. They were even despairing faces: as if the people they belonged to had done dreadful things and also suffered dreadful things. (48)

At the end of the line, the nadir of ongoing corruption, is the Witch. Lewis describes fallen humanity as "a horror to God and to himself and a creature ill-adapted to the universe not because God made him so but because he has made himself so by the abuse of his free will" (The Problem of Pain 63). The Witch is so 'ill-adapted to the universe,' that she succeeds in destroying a world. Lewis's fallen human nature, like Tolkien's Mirkwood, involves suffering 'dreadful' things, but also beginning to actively self-sabotage, finally seeming to become Death - even to itself. 
Although Tolkien and Lewis both conceive of death as collective and as a consequence of the Fall, both understand death, too, as personal and as a tragedy. Neither were strangers to death: apart from their experience of the First World War in early adulthood, both suffered trauma in their childhoods at the death of parents. At the age of three, Tolkien suffered the sudden loss of his father, causing the family to relocate from South Africa to England, where his mother also died eight years later. Lewis's mother died while he was still a young boy - a time which also brought the death of his paternal grandfather and uncle (McGrath 22; McGrath 24). ${ }^{154}$ The creators of Narnia and Middle-earth do not shy away from death; it is an inevitability to be faced. Instead, they embrace its true weight and tragedy, even as they assert the beauty of life in its fleetingness.

Lewis reflects on his mother's death in Surprised by Joy (1955) with a gravity that is reflected in other of his stories. This experience of death was a watershed moment in his childhood, one which dissolved any childish sense of security and home. Here, Lewis describes experiencing the loss of his mother before her illness had even killed her:

For us boys [meaning himself and his brother] the real bereavement had happened before our mother died. We lost her gradually as she was gradually withdrawn from our life into the hands of nurses and delirium and morphia, and as our whole existence changed into something alien and menacing, as the house became full of strange smells and midnight noises and sinister whispered conversations. (21)

Similarly, at the chronological beginning of the Narnia sequence, when the reader and Polly first meet the boy Digory, the first thing the reader learns about him is that his mother is mortally ill. Her illness is the reason he's been crying. As was the case for Lewis, Digory's grief is for the mother who already feels lost to him. Moreover, for Digory, the impending death of his mother betokens other endings: because his father was away in India, Digory and his mother are forced to move from the country to the city when she becomes ill. This change of place signals a sort of metaphorical death to pastoral innocence and carefree childhood. Digory irritably admits to crying: "And so would you [...] if you'd lived all your life in the country and had a pony, and a river at the bottom of the garden, and then been brought to live in a beastly Hole like this" (10). Digory's own experience and fear echo Lewis's own, as described in his autobiography:

all settled happiness, all that was tranquil and reliable, disappeared from my life. There was to be much fun, many pleasures, many stabs of Joy; but no more of the old security. It was sea and islands now; the great continent had sunk like Atlantis. (Surprised by Joy 23)

${ }^{154}$ Sue Jenkins notes in her essay "Love, Loss and Seeking: Maternal Deprivation and the Quest" that maternal deprivation was common experience of several fantasy authors at the turn of the century, such as Tolkien, Lewis, and G. K. Chesterton. Walt Disney's preoccupation with mother figures and their deaths also comes to mind. 
Death for Lewis is not only theology, and it is not distant; it is personal, earth-moving, and lifealtering. Perhaps his fiction was a way in which he could compensate for his own loss by having Digory save his mother. ${ }^{155}$ Through Digory, Lewis removes the question of death from the realm of the abstract, and brings it into the personal and experiential.

Thus, one wonders whether Lewis, driven by a sense of personal loss, investigates his theology of death in the world through fiction. He sets a personal experience of death against the backdrop of the Eden-like context of original sin. The reader has the impression that Digory (and perhaps Lewis too) is viewing all events through the lens of the death of his mother. All Digory's actions become defined by his concern for his mother and his "sweet hope" (The Magician's Nephew 103) of healing her. When the Witch is transported from her world into modern-day London, Digory's main concern is his mother: "if that creature went into her room [she] might frighten her to death" (72). When it occurs to him that "fruit from the land of youth" (81) might exist in other magical worlds, he plans to "hunt through them all. And then - Mother well again. Everything right again" (82). Lewis sets up an expectation in the reader, not only of the possibility for a miraculous cure for Digory's mother, but also of a cure for death altogether. Even as Lewis asserts the origins of death in the story of Adam and Eve, he also acknowledges the personal experience of death, depicting it as a symptom of something deeply wrong with the world.

The very emphasis on death in the theology of the Fall itself places a high value on life, transient and doomed as it is. Whereas Lewis focuses on the gravity and grief of death to express a state of fallenness in a sinful world, Tolkien's way of demonstrating the tragedy of death is instead to juxtapose it with the holiness and the sanctity of life. Like Digory, Tolkien's characters make it very clear that life is precious. Gandalf admonishes Frodo for wishing that Gollum had been killed. When Frodo asserts that Gollum deserves death, Gandalf answers,

Deserves it! I daresay he does. Many that live deserve death. And some that die deserve life. Can you give it to them? Then do not be too eager to deal out death in judgement. For even the very wise cannot see all ends. [...] My heart tells me that he has some part to play yet, for good or ill, before the end. (The Fellowship of the Ring 59)

That Gollum's 'part to play' is the act which actually fulfils the quest is only part of the point Tolkien is making. Tolkien's careful emphasis on mercy profoundly valorises life, even cruel and wicked life. Gandalf's mercy here is a theme that Tolkien develops throughout the rest of the

155 Wilson wonders whether Lewis's own childhood "was not so much forgotten as mythologized" (C.S. Lewis: A Biography loc. 295), insinuating that even in Lewis's autobiography he somewhat defamiliarised his own life. It is a point both Wilson and Adey also pick up with Puddleglum as an image of Lewis's gardener Fred Paxford (see Wilson, loc. 2569, and Adey, 173), who was according to Wilson an "incurable pessimist" (loc. 2569). 
narrative. When evildoers are defeated - Gollum, Saruman, Gríma Wormtongue, and others they are met with mercy and the chance for reconciliation rather than death, though medieval epics typically end in the death of the monster or antagonist. ${ }^{156}$ Aragorn even cautions his comrades in Fangorn Forest against shooting at a figure who appears to match the description of their enemy: "We may not shoot a man so, at unawares and unchallenged, whatever fear or doubt be on us" (The Two Towers 492-93). Aragorn's reference to 'challenging' calls to mind a medieval knight's formal challenge (sometimes used to determine a legal outcome), suggesting that even a guilty man should have a chance to defend himself honourably. Milbank points out that

[t]his mercy, in [...] Tolkien, is partly a reverential attitude to being and existence itself as a good thing. It is good to move and have one's being, but not to destroy others. The morally upright characters in Tolkien's novel are always unwilling to take life or assert power over it. (71)

By emphasising the beauty and value in life, Tolkien necessarily positions death, even the death of enemies, as a lamentable departure from what is good. Faramir, for his part, tells Frodo and Sam, that although he is under orders to kill any trespassers without question, "I do not slay man or beast needlessly, and not gladly even when it is needed" (665). Faramir verbalises Tolkien's veneration for the sanctity of life, whether it be lived wickedly or well; he advocates the moral duty to hold out (as Gandalf does with Gollum) for the possibility of redemption, even if it is unlikely. Although he acknowledges death, and even killing, is sometimes necessary, Faramir, like Gandalf, suggests that it is not for man to act as the final judge.

\section{Death as War}

Despite valuing life and mercy, neither author baulks at the gritty reality of death in the world. In their battles, whose details both seem even to enjoy, there is a sense of justice and of comeuppance for wrongdoing, and both Tolkien and Lewis write stories in which the battles are life-and-death. Tolkien's characters acknowledge that in a fallen world, killing can be appropriate, and in his essay "On Three Ways of Writing for Children," Lewis asserts the value in having good vanquish evil in stories: "[s]ince it is so likely that [children] will meet cruel enemies, let them at least have heard of brave knights and heroic courage [...]. Let there be wicked kings and beheadings, battles and dungeons, giants and dragons, and let villains be soundly killed at the end of the book" (66). In this way, Lewis evokes "a world of death, violence, wounds, adventure, heroism and cowardice, good and evil" (66). In comparison to Tolkien's

\footnotetext{
156 Beowulf kills Grendel and Grendel's mother, both Beowulf and St George slay dragons, Charlemagne kills Baligant, and King Arthur does eventually kill Mordred - though both Beowulf and Arthur die, too, in the killing of the dragon and Mordred.
} 
granting of grace even towards Saruman and Gollum, Lewis's 'soundly killing' off villains may seem rather bloodthirsty and pre-emptive (and perhaps even a little glib, if not deliberately defamiliarising for the sake of his imagined audience). However, it is important to remember that Tolkien's battle for Middle-earth, too, results in many deaths, of heroes and villains alike, and that the destruction of the Ring ultimately means the destruction of Sauron. Both Tolkien and Lewis are reluctant, however, to have their heroes do the killing. The steward Denethor, for one, deep in the evil counsel of Sauron, brings about his own death at the funeral pyre of Faramir. Saruman is betrayed and killed by his own agent Gríma Wormtongue. In Lewis's fiction, the White Witch, though in battle with all the Narnians, is finally killed by Aslan (whose place and power she had originally appropriated), and not by the children; the unjust governor, Gumpas, in The Voyage of the Dawn Treader (1952) is displaced by the overturning of his table and the appointment of another governor, allowing him to leave with his family and belongings; and the Telmarines who had moved in and oppressed the Narnians in Prince Caspian (1951) are the ones who kill their own Telmarine King Miraz in the end. Even they are offered the opportunity to start over, transported to a new land.

Both Tolkien and Lewis personally experienced battle, and as has been mentioned earlier, some of their descriptions of battles could be seen as defamiliarisations of their own experiences. The First World War would have been their first experience of death on a large scale, and it is clear that both felt the horror of it collectively and personally. ${ }^{157} \mathrm{~T}$. A. Shippey in particular is very eloquent on the comparison between the Dead Marshes in Tolkien and First World War battlefields "where the static warfare left the dead unburied for years, with both sides inextricably confused" (J. R. R. Tolkien: Author of the Century loc. 3744). Lewis lost his close friend Paddy Moore, and was himself wounded by an explosion that killed the man standing next to him, Sergeant Harry Ayres (McGrath 71). Both Tolkien and Lewis then lived through the Second World War, and it was at this time their writing careers were beginning to take off. Several readers therefore believe that wars in their fiction are explicit responses to and representations of their own experiences of the First and Second World War - such as that Tolkien's One Ring and Lewis's 'Deplorable Word' are weapons analogously linked to the atomic bomb. ${ }^{158}$ Indeed, all three are great weapons designed to be the final resort in battles already raging. The Witch of The Magician's Nephew is not content with the banquet massacre of her

\footnotetext{
${ }^{157}$ For the influence of the war on Tolkien and Lewis, see Colin Duriez, Tolkien and C. S. Lewis: The Gift of Friendship (2004) and J.R.R. Tolkien: The Making of a Legend (2012); John Garth, Tolkien and the Great War: The Threshold of Middle-earth (2005); K. J. Gilchrist, A Morning After War: C. S. Lewis \& WWI (2005); Joseph Loconte, A Hobbit, a Wardrobe, and a Great War: How J. R. R. Tolkien and C. S. Lewis Rediscovered Faith, Friendship, and Heroism in the Cataclysm of 1914-1918 (2017); and Martha C. Sammons, War of the Fantasy Worlds: C. S. Lewis and J. R. R. Tolkien on Art and Imagination (2010).

${ }^{158}$ See Kathryn Walls, "When Curiosity Gets the Better of Us: The Atomic Bomb in The Magician's Nephew" (2008), which also suggests that Uncle Andrew's magic rings defamiliarise the Atomic bomb.
} 
forefathers and her mode of genocide is a spell, the Deplorable Word, "which, if spoken with the proper ceremonies, would destroy all living things except the one who spoke it" (60). This phrasing anticipates the language of mutually assured destruction which surrounds discussions of atomic weapons. ${ }^{159}$ The correlation between the two authors' experience of the First World War and their fictional depictions of mass fatalities suggests that they are using their fiction, at least partially, to address questions of large-scale death and genocide. It may be that the sense of impending doom in their writing, and the principle of giving one's life to a noble cause are a natural consequence of this war experience: these values were internalised by soldiers in the trenches. In fact, Amendt-Raduege claims that "For all its fantastic trappings [...] The Lord of the Rings is essentially about the very things [...] soldiers experience: friendship, sacrifice, loyalty to a cause higher than oneself, and, above all, the brutal reality of death" (2). Even though the entire notion of a noble death is famously critiqued by the literature emerging in the wake of the First World War, most notably Wilfred Owen's poem "Dulce et Decorum Est" (1920), both Tolkien's and Lewis's heroes offer to lay down their lives as a gift, as a final and appropriate tribute to a worthy and noble cause.

There is agency and nobility in choosing what one's death will mean, and what causes are worth the giving of one's life - this is a sentiment frequently expressed by Tolkien's protagonists. ${ }^{160}$ A good example of this is King Théoden in the long night of the Battle of Helm's Deep, expressing a very Anglo-Saxon sentiment, such as is seen in the poem "The Battle of Maldon". Facing what seems to be inevitable defeat as the last of the besieged outposts are being taken by the enemy, Théoden is unwilling to "end here, taken like a badger in a trap" (The Two Towers 539). In the face of what he deems to be certain death, he decides to ride out: "Maybe we shall cleave a road, or make such an end as will be worth a song," he says (539). ${ }^{161}$ Such sentiments are not uncommon in Tolkien: Aragorn speaks for the whole company and its mission as the Fellowship breaks up at the end of The Fellowship of the Ring, when he decides to

159 The term 'mutually assured destruction' was coined by Donald Brennan in 1962.

160 There are many such stirring speeches to choose from as the characters muster their strength and resolve against the Enemy. Notable examples can be drawn from the chapter "The Last Debate" in The Return of the King: Aragorn says "For, my lords, it may well prove that we ourselves shall perish utterly in a black battle far from the living lands; so that even if Barad-dûr be thrown down, we shall not live to see a new age. But this, I deem, is our duty. And better so than to perish nonetheless - as we surely shall, if we sit here - and know as we die that no new age shall be. [...] We come now to the very brink, where hope and despair are akin. To waver is to fall" (880).

161 Much could be made here too of the glorious battle cry of Aragorn in Peter Jackson's 2003 film rendition of Return of the King, a speech entitled 'Men of the West', which displays similarly heroic and hopeless themes, of giving of themselves unto death, not out of necessity, but for a dream: "Sons of Gondor, of Rohan, my brothers! I see in your eyes the same fear that would take the heart of me. A day may come when the courage of men fails, when we forsake our friends, and break all bonds of fellowship; but it is not this day! An hour of wolves, and shattered shields, when the Age of Men comes crashing down; but it is not this day! This day we fight! By all that you hold dear on this good earth, I bid you stand, Men of the West!" (The Lord of the Rings: Return of the King). 
pursue and rescue Pippin and Merry, saying: "With hope or without hope we will follow the trail of our enemies" (420). Hope - that is, probability of success - is not, nor has it ever been, a part of their quest. T. A. Shippey notes that this "theory of courage" was for Tolkien the "great contribution' to humanity", where Old Norse mythology "was like the traditional Christian one in that it too ended in a Day of Doom, an Armageddon, in which the forces of good and evil finally confronted each other" (J.R.R. Tolkien: Author of the Century loc. 2720). He asserts that Tolkien "wanted his characters [...] to live up to" this standard of Northern courage "and was careful to remove easy hope from them, to make them conscious of long-term defeat and gloom" (loc. 2720). Nevertheless, instead of paralysing them, despair galvanises Tolkien's characters to march with determination towards their doom; the characters refuse to allow their death or sacrifice to be meaningless. Tolkien's iterations of death perform an eloquent analogy of teleological existence, an existence that has meaning and purpose. Even the manner of death gives the life meaning and purpose, as with Boromir whose death redeems his life. Put another way, even in the face of death, Tolkien's characters insist upon the meaningfulness of life.

For Tolkien, life is a gift, and even death is a giving. As Milbank notes in her chapter on gift exchange, Théoden "[becomes] a gift himself in his heroic charge against the hosts of Mordor at the Battle of Pelennor Fields, in which he gives his life to the cause" (129). Milbank further notes that in pre-Christian days "[e]arly humans gave gifts to the dead to witness that life itself is a gift" (156).162 The value of a life is measured not by how it affects the outcome of the battle, but by its being given at all - once again according with Anglo-Saxon and Northern ideas of nobility and heroism. Shippey notes that "even if the universe [in Tolkien's schematic] is controlled beyond redemption by hostile and evil forces, that is not enough to make a hero change sides" (J. R. R. Tolkien: Author of the Century loc. 2720). The greatest honour, however, lies in the integrity of the mission for which the characters are willing to risk their lives. And even in dying there is a paradoxical sense of having won some final victory: "I go to my fathers," Théoden tells Merry, "And even in their mighty company I shall not now be ashamed" (The Return of the King 842). It should be noted that, despite a high number of deaths of named characters, there is a relatively low death count amongst the foregrounded protagonists, with a few notable exceptions, even during the battles. The battle is not for the life of man but for the vitality and integrity of the soul. This idea is drawn directly from gospel: "For what profit is it to a man if he gains the whole world, and loses his own soul? Or what will a man give in exchange for his soul?" (Matthew 16:26). Although Jesus's questions are rhetorical, perhaps this gift

162 "[I]n the same way," she continues, "Father Christmas gives to children, and adults through him, because they [the children] themselves are the gift" (156). 
theory is Tolkien's answer. The object is not to fight for one's own life, but to gain something for another (even if only for future generations and future good) by laying it down. ${ }^{163}$

There is an important distinction to be made, however, between resisting death and doom, which is noble, flight from death, which is not. In "Literary Apologetics beyond Postmodernism," Milbank notes what she considers to be a troublesome trend in Philip Pullman's fantasy where death is "an actual vol-de-mort, 164 or flight from death's reality" (112). In her view, Pullman never actually commits to the metaphysics of death. His characters seem to dissolve into the universe, night, starlight, and air (103). Thus, Pullman does not accept "the transcendent and also the acceptance of death that makes rebirth a possibility" (104). She does not see any hopefulness or satisfying resolution in Pullman's depiction of death. The difference in viewpoints between them comes down to belief, as Pullman is an atheist. He instead chooses a postmodern approach which evades "pure annihilation" (106). Interestingly, the desire to cheat death is a common characteristic of many of the antagonists in fantasy fiction. Indeed, this is the motivation of the (obviously named) Voldemort in J. K. Rowling's Harry Potter legendarium, as well as the dubious N. I. C. E. scientists in Lewis's That Hideous Strength (1945). For Milbank, the desire to escape death denies its gravity and inevitability.

An acceptance of death is appropriate, as Tolkien demonstrates in the mixed blessing of the longevity the cursed One Ring grants to its wearer. Its power to make the wearer invisible is entertaining: it enables the hair's breadth escapes of Bilbo in The Hobbit, and his famous disappearing trick at his eleventy-first birthday party. Yet even Bilbo is vaguely aware of the Ring's sinister influence. He can't understand why he should be so "well-preserved" when he feels himself to be dreadfully old. “I know I don't look it, but I am beginning to feel it in my heart of hearts. [...] Why, I feel all thin, sort of stretched, if you know what I mean: like butter scraped over too much bread. That can't be right" (The Fellowship of the Ring 32). The very hobbit-ish food analogy aside, what Bilbo expresses here is ominous. His is not the natural immortality of the Elves; Tolkien is at pains to show that it is an unnatural prolonging, outside of Bilbo's control or desire, stretching him almost beyond what he can bear. As Verlyn Flieger writes,

\footnotetext{
163 It is worth noting then, how the contrast is evoked between the two sides in Tolkien's final battle scenes. The minions of Sauron clearly have no such grand ideas about losing their life to a cause - a response meant to draw attention either to their moral failings (that fear or mass thought control account for their actions thus far), or the worthlessness of their cause. At the doom of Sauron, they scatter, kill themselves, and only a few ask for mercy (949). Perhaps Tolkien is encouraging his reader to look on these deserters mercifully in the same way that Frodo does with Gollum. Without a cause worth giving their lives for, Tolkien would not have even his villains spend their lives needlessly. He writes resistance to death - that is, none of his heroes entertain the thought of death unless in absolute extremity. The Ents, for example, are only roused when "it is clear to us that our trees and our lives are in great danger" (The Two Towers 485). ${ }^{164}$ Here Milbank references J. K. Rowling's Dark Lord Voldemort, whose whole character arc is set in motion by the desire to evade death at all costs (thus creating the horcruxes).
} 
"deathlessness is not true immortality," but rather "bondage to the world without hope of renewal" (Splintered Light 29). It is only at the introduction of Sméagol that the reader begins to understand the reason for the unease behind Bilbo's testimony. Gollum, as he becomes known, gains power from the Ring, but it increases both his distance from life and his malicious nature. Gandalf explains: "You see, though still bound by desire of it, the Ring was no longer devouring him [which enabled him to come out into the open after many years]; he began to revive a little. He felt old, terribly old, yet less timid, and he was mortally hungry" (75). The result of Gollum's ill-gotten long life was that his mortal life was gradually eroded: he lost family, he lost time in the darkness of deep caves away from the sun and seasons, he lost appetite as the Ring fed off him. Without it, he felt old, yes, and hungry, but revived. The Ring staved off both death and life, robbing him of what remained of his humanity. As Amendt-Raduege puts it, Tolkien emphasises "not the injustice of death but the injustice of not being allowed to die" (5). Gollum shows the futility and hollowness of a false immortality. As with T. S. Eliot's Cumean Sybil at the beginning of "The Waste Land" (1922), and in every fairy tale, the quest for immortality for its own sake always comes at a cost and seldom benefits the seeker.

Tolkien's One Ring embodies the fascinating paradox of the theology of death in the world, that the desire to escape death is itself a consequence of death, and therefore for Tolkien (though not explicitly so in the trilogy) part of the consequence of the Fall. Implicitly, both Tolkien and Lewis suggest that physical death is linked to the spiritual death of the Fall. Lewis's Witch, as a personification of Death itself, desperately clings to life. In The Magician's Nephew, she speaks a word that will kill everyone but herself, and she is anxious to escape death and win immortality (as she believes) by eating the apple in Aslan's garden. In her words, the "apple of youth, the apple of life" ensures she "shall never grow old or die" and will "live forever" (150). Her taunts at Digory's refusal to do the same are vivid: "Think of me, Boy, when you lie old and weak and dying, and remember how you threw away the chance of endless youth!" (152). Yet she only succeeds in winning for herself fleshly triumphs. She wins "unwearying strength and endless days like a goddess" (162) by stealing and eating the magic apple, but her version of illgotten immortality is shown up as a half-life. Her own flesh becomes corpse-like, "deadly white, white as salt" (149), and despite the immortality of her flesh, her attempts to find physical rather than spiritual remedy against death are misdirected: readers know that she is nevertheless killed in The Lion, the Witch, and the Wardrobe. Her pursuit of 'endless days' is ultimately a futile endeavour. With childlike practicality, Digory responds to her taunts rather simply, "I don't know that I care much about living on and on after everyone I know is dead. I'd rather live an ordinary time and die and go to Heaven" (The Magician's Nephew 150).165 When

165 This is a clash of worlds, Narnia and Heaven, incidentally, that Tolkien would never have allowed. 
juxtaposed with the prospect of trying to save his mother's life, the Witch's actions cause Digory to decide that "there might be things more terrible even than losing someone you love by death" (163). Even the loss of his mother, in other words, is not so terrible as the 'immortality' the Witch offers. The Witch's attempts to stave off her own death are fixing the symptom, not the cause. ${ }^{166}$ The Witch, as Death, represents the law of death governing fallen humanity, and the futility of attempts to escape that death. Through her, Lewis depicts fallen humanity as pursued by death until Christlike sacrifice brings life (and the promise of immortality or Heaven). Death is both the evidence of the Fall, and the act that undoes it (through Christ). Lewis uses the Witch to set up the problem of death and immortality in order to solve it later on.

Another fascinating example of the flight from death is the Un-Man Weston in Lewis's Perelandra (1943). Ransom finds himself on the unfallen planet of Perelandra, where Weston, the misguided scientist, is found to be playing the part of tempter to that planet's queen ${ }^{167}$ herself a kind of unfallen Eve. In the previous Out of the Silent Planet (1938), Weston was presumed dead. Yet he is apparently revivified by some diabolical force: the "body was alive" but Weston is gone (Perelandra 230). He appears as "a man who was certainly Weston" but also "unrecognizable": "He did not look like a sick man: but he looked very like a dead one" (242). From the point that Weston calls the force into himself, there is a noticeable shift in Ransom's narration, calling him “it” or "Weston's body” (244) or “Weston's shape” (246). It becomes a "night-nursery horror [...] - the managed corpse, the bogey, the Un-Man" (253). Given that Lewis was in awe of creation, this evocation of the Un-Man as something deeply disquieting is striking. We respond to him with "disgust, [and] the more childlike terror of living with a ghost or a mechanised corpse" (258). The Un-Man is contrary to nature; his deathlessness is an uncanny reversal of good creation - a defamiliarisation of both life and death.

Before reversing the effects of the Fall, Lewis explores why such a reversal of the Fall is necessary. He defamiliarises in order to show why redemption is needed. The Un-Man is living death, "corruption itself to which will was attached only as an instrument. Ages ago it had been a Person: but the ruins of personality now survived in it only as weapons at the disposal of a

\footnotetext{
${ }^{166}$ Even when the evil Nikabrik attempts to conjure her up again from the dead in Prince Caspian, there is no real sense of her regaining life if they had succeeded. Although the hag asserts "who ever heard of a witch that really died? You can always get them back" (Prince Caspian 146), Caspian calls it "Black sorcery and the calling up of an accursed ghost" (147). Even if she were more than ghostlike, what she would have lived in that form could scarcely be life as she had known it.

${ }^{167}$ Adey has the Un-Man as deriving from "immediately from Weston's having toyed with a dark Power beyond his comprehension, and ultimately from [Owen] Barfield's explanation (in the "Great War") of Steiner's distinction between "Lucifer," the devil appealing to human pride and wish for knowledge, and "Ahriman," the devil of materialist technocracy" (125), which is itself a form of defamiliarisation, not least because in the previous novel Weston "acted as Lucifer" and his co-conspirator Devine played the part of Ahriman (126).
} 
furious self-exiled negation" (282). In these early years of Lewis's fantasy writing, he is not mincing his words. Weston himself, now scarcely even a consciousness in the Un-Man's body, is allowed to reappear only once, speaking to Ransom as if from the grave to describe death as "Darkness, worms, heat, pressure, salt, suffocation, stink. [...] Right down under layers and layers. Buried alive" (295). At the end, the Un-Man has to be thrown off a cliff into a chasm in the depths of the earth before It can be defeated. Being already dead, It was not hindered by broken bones or drowning, but kept being reanimated by that Force which entered Weston at his own invitation. The Un-Man is Lewis's chilling evocation of a living death, an unsettling reversal of Jesus's words in John 10:10, "I am come that they might have life, and that they might have it more abundantly," for the Un-Man tells the Lady that "it is for this that I came here, that you may have Death in abundance" (246). As Lewis wrote Perelandra after The Screwtape Letters (1940), it is no surprise that he was already adept in taking an idea of Biblical good (e.g. the concept of 'life in abundance') and capturing its negative or inverse image. What animation the Un-Man has can scarcely be called life, however much powerful knowledge that Force allegedly gave him. This is the consequence of the Fall, and this is the fate the unfallen Lady of Perelandra succeeds in escaping. Lewis defamiliarises the whole arc of salvation, contrasting fallenness with redemption, humanness, and godliness. Lewis's Un-Man evokes a kind of immortality, but the wrong kind - that of 'being like God' which was the serpent's temptation to Eve (see Genesis 3:5). Quite apart from establishing Christ-figures, Lewis is looking at what is necessary to make the doctrine work. Here, the Un-Man is illustrating depravity in the extreme. As Milbank has noted in other Christian fiction, authors "take their readers deep into the darkness [...] and the inability of the world to save itself" (Chesterton and Tolkien as Theologians 113). Lewis wants his readers to ask themselves why this iteration of life/death feels wrong, and what would make it better.

Because the concept of death in these works is so caught up in the theology of the Fall, a preoccupation with the brokenness of the world obliquely points towards the redemption of that brokenness. The arc of fall-to-redemption may be seen as justification for defamiliarisation, in that defamiliarisation enacts, in microcosm, its own fall and redemption of meaning. The reader (and the writer) lose the 'given' world in order to regain it once more as new. The reader reads through a lens which first obscures both biological death and Christian doctrine in fantastic defamiliarisation, and then dazzlingly restores: biological death is valorised, when for the believer it "transcends death and leads to God" (Flieger, Splintered Light 29), for the notion of a physical resurrection (whether of Aslan or others) depends upon a physical death. If the tragedy of death is that it is an ending, then its remedy is a 'continuing' - not mere reanimation or prolonging, but a transformation or going on to something beyond death. Milbank observes 
that "the more death is allowed its full horror and menace, the more it ceases to be a totality but an opening out" ("Duality and Death" 113) within that theological paradigm. Acknowledging death to be a tragedy is acknowledging that all is not well. This very acknowledgement begins implicitly to propose an alternative where 'all shall be well, and all shall be well and all manner of thing shall be well'.168 The door is opened to discussion and to hope, or, as Tolkien would call it, Consolation. The kind of consolation that Tolkien and Lewis propose for death is life: life renewed, life reborn, or life beyond. For them, as Flieger puts it, "[t]he real escape from death is through death to eternal life" (29).

\section{Life: There and Back Again}

The Paradox of the Grain of Wheat Principle: Dying to Live

Wherever Tolkien and Lewis conceptualise a reversal of the Fall, there is a deliberate evocation of a return to unfallen Eden. In this, Tolkien and Lewis do not so much defamiliarise as imagine a reversal of the effects of the Fall: for both, this is most clear in their evocations of nature. For Tolkien, lovingly evoking a sense of Eden (in the new tree planted in Gondor after the battle at the Black Gate, and wherever the natural landscape flourishes after the evil is expunged, in the endings of both The Hobbit and The Return of the King) harmonises with a Biblical conviction of the New Creation promised - of humankind (see 2 Corinthians 5:17), and moreover of Creation itself in Revelation 21: "And I saw a new heaven and a new earth: for the first heaven and the first earth were passed away" (21:1). The understandable lack of consensus amongst Christian theologians about the precise nature of the afterlife allows Tolkien considerable freedom. Tolkien does not write an actual regaining of paradise, but rather suggests the terms in which one might imagine it: as Creation remade, according to Revelation 21:1 which describes "a new heaven and a new earth; for the first heaven and the first earth were passed away". There is a deliberate evocation of Eden-like imagery in his descriptions of landscape, which seems to suggest a reversal of the exile from Eden: in the land becoming rich and right again, the world is being restored to its original version, restoring Paradise. The Desolation of Smaug, an expanse of scorched earth surrounding the Lonely Mountain where the dragon lived, is resurrected after his demise: "all the valley had become tilled again and rich, and the desolation was now filled with birds and blossoms in spring and fruit and feasting in autumn" (286). And the ousting of the last Necromancer from Mirkwood, for instance though not an instance in which all evil in Mirkwood is tackled, will permit the forest to "grow

\footnotetext{
168 This phrase is attributed to Julian of Norwich, who paraphrased the promise of Jesus (Julian of Norwich 54-55). Her words were borrowed by T. S. Eliot in the last section of Four Quartets (1942), "Little Gidding".
} 
somewhat more wholesome" (The Hobbit 281). There is a new white tree planted in Gondor, and the Shire experiences a kind of renewal after its scouring, and hobbit holes are "snugger and drier" (The Return of the King 1022). Sam's trees, including the Elvish mallorn whose seed Galadriel gave to him, "began to sprout and grow, as if time was in a hurry and wished to make one year do for twenty" (1023). The Shire experiences "an air of richness and growth, and a gleam of a beauty beyond that of mortal summers that flicker and pass upon this Middle-earth" (1023), and such a harvest that "every barn was stuffed" (1024), "young hobbits very nearly bathed in strawberries and cream" (1023), and "no one was ill, and everyone was pleased, except those who had to mow the grass" (1023).The contrast of Tolkien's landscapes is appropriately fairy-tale-like: famine or plenty, dead or alive. At the heart of the lost-and-found, fall-and-redemption arc, is the Biblical concept or motif of being 'born again.' This concept is drawn from the Gospels, but particularly in this instance from John 12:24: "Except a corn of wheat fall into the ground and die, it abideth alone: but if it die, it bringeth forth much fruit".

Lewis's landscapes similarly mimic the fortunes of the people in the land. When the Telmarines take over Narnia in Prince Caspian (1951), for example, the palace of Cair Paravel becomes run down and overgrown. Even so, it has sprouted a healthy and thriving grove of fruit trees; where Tolkien paints the landscape as either cursed or blessed, Lewis retains a spark of life or hope in the unlikely flourishing of a cursed landscape. The wilderness of the snowy forests is illuminated by the lantern that grows there. Although it does not take away from the desolation and is itself something mechanical in a natural environment, the lamppost diminishes the sense of threat by its familiarity and its light. Lewis's landscapes are magical in a different way from Tolkien's: there is always the sheen of enchantment, the sense of a curse to be broken. While the White Witch's spell in The Lion, the Witch and the Wardrobe does bring about an unending winter (and never Christmas), there is nevertheless a pleasant sense of an enchanted forest when Lucy steps through the wardrobe - nothing like the grim plains surrounding Sauron's tower in Mordor. Perhaps because they were targeted towards younger children, the Chronicles of Narnia do not dwell on the manifestation of evil in the land as Tolkien does in his Dead Marshes, for example, which speak of hard battles, great loss, and the victory of evil. In the Chronicles, Lewis opts for the enchanted forest trope, rather than Tolkien's grittier version of pathetic fallacy in landscapes which includes haunted and diseased ground. The vitality of Narnia is first evident in the extreme fertility of being newly called into existence in The Magician's Nephew, as seen by the rapid growth of all that is planted there - including a lamppost from a bar of iron and a tree that grows toffees from a sweet the children plant. An apple that Digory throws into a riverbank becomes a fully-grown tree within a single day. Even the sun "looked younger. You could imagine that it laughed for joy as it came up" (95). The 
colours are "fresh, hot, and vivid. They made you feel excited" (95). The health and abundance of Narnia reflects divine presence and also denotes its absence. After all, in the absence of Aslan Narnia does not feel "that strange feeling - like the first signs of spring, like good news" (The Lion, the Witch and the Wardrobe 74) that he evokes. ${ }^{169}$ The Witch's evil reign is broken by Aslan's return and resurrection, banishing deathly winter so that Narnia is reborn again into a sudden and conclusive summer - the thaw of the winter ends so rapidly that flowers are already blooming through the snow and "the whole wood pass[es] in a few hours or so from January to May" (113). Or, as Sue Matheson puts it, "The Lion creates Narnia, and, by his own death and rebirth, re-creates the creation. He is 'the genesis of restoration from decay'" (15). Aslan begins the winter-to-summer transformation that Narnia undergoes, which also foreshadows his own resurrection. The reversal of Narnia's fortunes is writ large as a reversal of the Fall (but only in part, as the 'new creation' only comes at the end of the seventh book): Lewis's fantasy embodies a yearning for the restoration of Eden. Chesterton's pithy expression, mentioned earlier, eloquently captures these longings for restoration: "All poems might be bound in one book under the title of 'Paradise Lost.' And the only object of writing 'Paradise Lost' is to turn it, if only by a magic and momentary illusion, into 'Paradise Regained"' ("The Romance of Rhyme" 117).

\section{The Paradox of Home}

The restoration of Eden, Paradise Regained, is inextricably linked with a sense of ultimate homecoming, both in the Bible and in the works of Tolkien and Lewis. Donald Haase points out in "Children, War and the Imaginative Space of Fairy Tales" (2000) that many of these narratives begin with displacement, the characters, like the hobbits and the children in The Lion, the Witch and the Wardrobe "have been displaced by violence" (362), whether the actual World War or merely the threat of one. Because of this displacement, there needs to be a projection of some kind of reconstituted home on the new landscape in which they find themselves. Where is home when you're a halfling squire of Gondor, or a King of Narnia with an adolescent future waiting in London? Through the character of Bilbo in The Hobbit, Tolkien is especially eloquent on the subject of home. Bilbo seems an unlikely character, at first, to dignify the idea of home: at the beginning of the book, his disinclination for adventure and pathetic desperation to be back in his little hobbit hole are used to comic effect. Tolkien delights in snippets of hobbit-like homeliness, telling the readers that Bilbo would say to himself, "I wish I was at home in my nice hole by the fire, with the kettle just beginning to sing!' It was not the last time that he wished

169 That "good news" is an example of the kind of sacramental simile (for good news or Gospel) Lewis uses, that Tolkien carefully avoids. 
that!" (The Hobbit 43). Though he becomes less comic and ridiculous as his journey transforms him, Bilbo's desire for home is not trivialised as another of his foibles, but rather ennobled. In Bilbo's frequent reflections on his home, Tolkien suggests a longing for (ultimate) home. Bilbo's songs are an elegant expression of Tolkien's view of Heaven as home. Though a song in praise of the familiarity of home, Bilbo's nostalgia for the roads that "go ever ever on" (283) is evident in the ditty he sings upon his return. In the version of "Roads go ever ever on" in The Hobbit, "feet that wandering have gone / Turn at last to home afar" and eyes that have seen many marvels "Look at last on meadows green / And trees and hills they long have known" (284). This verse stands in stark contrast to the similarly named "Road goes ever on and on" when at last Bilbo sets out again in the beginning of The Fellowship of the Ring. At this point he has a very unhobbitlike plan without destination or return journey (come to that, it is a very un-Bilbo-like plan, given his initial aversion to leaving home at all). This time, he sings:

The Road goes ever on and on Down from the door where it began. Now far ahead the Road has gone, And I must follow if I can, Pursuing it with eager feet, Until it joins some larger way Where many paths and errands meet. And whither then? I cannot say. (The Fellowship of the Ring 35)

The first (in The Hobbit) is evidence of a typical hobbitlike approval and delight in home and familiarity, and the second (in The Fellowship of the Ring) is evidence of his transformation from the Bilbo he was to an adventurous version of himself - one who questions, is open to speculation, and longs for the untravelled path. And of course Bilbo returns home after his quest, but when he leaves the Grey Havens with Gandalf and Frodo at the end of The Return of the King, it is Sam who stands in for Bilbo in respect of the desire for home, by returning to his home and family in the Shire. The paradox of Bilbo's two songs, expressing both a longing for home and a longing for adventure, is evidence of Tolkien's gentle speculation about Heaven as one's eternal home, of the possibility of home being a place we've never been before (see Philippians 3:20). Jack Zipes speculates in Fairy Tales and the Art of Subversion (2006) that children's "desire for an ideal home" is similarly conceptualised as "a world or state in which they come into their own" (176). This is a home of true belonging. In "On Fairy-Stories", Tolkien describes his dedication to the idea of communicating a specific kind of joy in his writing: a joy of "a far-off gleam or echo of evangelium in the real world" (62). The word 'evangelium' (meaning 'good news' or 'gospel') is used deliberately by Tolkien to describe another death 
theme: the gospel of Christ's death, resurrection and the promise of eternal life through him. ${ }^{170}$ For this reason, Tolkien's delicate evocations of the joys of home and homecoming are shot through with the concept of eternality. It is both a place which is achingly familiar and comforting to the weary traveller ('turning at last to home afar'), and the adventure so grand that it cannot be imagined (joining 'some larger way', 'And whither then? I cannot say'). In one sense, the New Creation is intended as a final resting place, the ultimate homecoming, but simultaneously and in contrast, it is figured as a place which is somewhere beyond, lying at the end of a journey and part of a greater adventure.

Despite these clear evocations, Tolkien is reticent as to exactly what that home might be like. Unlike Lewis, he scarcely hints at any afterlife at all. Some readers have described Frodo's journey to the home of the Elves from the Grey Havens (at the end of The Return of the King) as a kind of Heaven, but this is problematic for many reasons, not the least of which is that it is only for the Elves. Frodo, Gandalf, and Bilbo are the only non-Elf characters to go there. As Kelly and Livingston assert in “'A Far Green Country': Tolkien, Paradise, and the End of All Things,” Tolkien espouses a writing style which leaves Paradise quite literally beyond description. He has what Mary R. Bowman calls "a strong taste for the non-narratable" "The Story Was Already Written" (275). In fact, they point out that throughout his writings, Tolkien consistently shies away from any explicit mention of what Paradise might look like, and only goes so far as to describe, as he does in the tale of "Leaf by Niggle," a temporary purgatory/paradise. Kelly and Livingston conclude that

Tolkien's 'far green country' is not Heaven. It is instead an asterisk-Eden:171 not the place of final return outside of the world, but a place of origin still somehow strangely caught up within it - a place that although it has perhaps lost its intended purpose is nevertheless still tantalizingly close to reachable [...]. (96)

It is a place "of peace and healing" from which the characters eventually would pass away (96), so even this "asterisk-Eden" is not Heaven. For Tolkien, there seems to be a peculiar difficulty in imagining Heaven, which for him is quite different from imagining an idyllic Eden. Quite unlike Lewis, Tolkien is reticent to define his idea of life after death, in the spiritual sense - though he

\footnotetext{
${ }^{170}$ Romans 6:8-10 asserts that "if we died with Christ, we believe that we will also live with him. For we know that since Christ was raised from the dead, he cannot die again; death no longer has mastery over him. The death he died, he died to sin once for all; but the life he lives, he lives to God."

${ }^{171}$ Kelly and Livingston have taken the idea of an asterisk-reality from Shippey's book The Road to Middleearth (1982), where he explains the use of the asterisk, philologically, to denote a "reconstructed form" (Shippey, The Road to Middle-earth 15) or, narratively, "that which no longer existed but could with 100 per cent certainty be inferred" (17).
} 
invents the physical resurrection of characters such as Gandalf. He evokes the afterlife as a kind of glorious homecoming, ${ }^{172}$ but he does not delineate it.

Lewis and Tolkien have, apart from their commentary on each other's work, both referred to fairy tale as expressive of a yearning or longing for something 'beyond' or not quite attainable. Milbank uses an example from the German philosopher Novalis to explain a kind of "homesickness for the ultimate truth" which Novalis portrayed in his novel through the metaphor of the hero's search for a certain kind of blue flower ("Making Strange" 33). This longing described by Novalis, however, may be unique to the fantastic fiction of religious writers, even only of certain religious camps, as writers with different religious views or none, such as Philip Pullman and Ursula Le Guin, express such views without resolving into a Heaven/Hell framework. ${ }^{173}$ In Milbank's religious conceptualisation, however, the task of fantasy is to "awaken what one might call the religious sense, that homesickness for the absolute" (44). While this may be a characteristic specifically of fantasy that has some connection to a religious framework (outside of that of the fantasy world), that fantasy world itself could be said to be the expression of Novalis's longing, that kind of enhanced reality of the fantasy realm satisfying the yearning for something beyond of the bounds of this world. This theory is supported by Francis Spufford, who writes of the Narnia books that

C. S. Lewis invented objects for my longing, gave forms to my longing, that I would never have thought of, and yet they seemed exactly right: he had anticipated what would delight me with an almost unearthly intimacy. Immediately I discovered them, they became the inevitable expressions of my longing. [...] They were the Platonic Book of which other books were more or less imperfect shadows. [...] Once felt, never forgotten. (The Child that Books Built 87)

This idea of 'homesickness' is notable in that it illustrates that ethereal quality of joy that both writers try to evoke in their work: what Lewis calls "an unsatisfied desire which is itself more desirable than any other satisfaction" (Surprised by Joy 20), and what Tolkien's describes as a deep yearning for "such joy [that] has the very taste of primary truth" ("On Fairy-Stories" 63). This joy is "a sudden miraculous grace" (60), and while it does not deny sorrow or failure, neither does it concede ultimate defeat. It is "evangelium, giving a fleeting glimpse of Joy, Joy beyond the walls of the world, poignant as grief" (60). This Joy powerfully echoes the homesickness to which Novalis alludes, a joy that goes beyond the walls of the world. Lewis

172 The film version attempts, not entirely successfully, to supply this idea in a conversation between Gandalf and Pippin, besieged in Gondor assuming it is the end. The words are actually taken from Frodo's journey from the Grey Havens, when "he beheld white shores and beyond them a far green country under a swift sunrise" (The Return of the King 1030).

173 Adey points out, however, that even in The Last Battle, there is "no mention of Hell", and those who do not make it to the Platonic new Narnia "simply vanish" (188). 
distinguishes this joy from happiness or pleasure; it shares with these only the characteristic that "anyone who has experienced it will want it again." He goes on to say that this Joy "might almost equally well be called a particular kind of unhappiness or grief. But then it is a kind we want [...] [and would never] exchange it for all the pleasures in the world" (Surprised by Joy 20). Joy is a desire which is in itself almost as desirable as its object, which is pleasurable (though it is not Pleasure), which hankers for the absolute, for the True. For Lewis, the task of literature is to evoke (and perhaps inspire) this longing. Literature is the vehicle "to go through and beyond [...] to an imagined something which is not itself verbal" (An Experiment in Criticism 88). In fiction, he writes, "we seek an enlargement of our being. We want to be more than ourselves" (137). Fiction "can give us experiences we have never had and thus, instead of 'commenting on life', can add to it" ("Sometimes Fairy Stories" 74). In the work of both Lewis and Tolkien, depictions of the hereafter gesture towards this longing for something they cannot quite imagine or define. For Tolkien, this means making his defamiliarisation of the Biblical Heaven somewhat ambiguous and mysterious. Even in "Leaf by Niggle", the characters experience For Lewis, the afterlife becomes a more real reality.

Lewis was a little more Platonic than Tolkien, therefore, in imagining what a paradise might look like. This formula is set up rather early on in his Narnia books, before paradise (Aslan's country) is even encountered. To Lewis, this was a kind of homecoming, one that was very much present in his imagination since his days in the war, as Wilson puts it: "[h]olidays with no school term to cloud them, the condition of being perpetually at home, these were to become images in his mind of the heavenly places" (loc. 1216). Even as in the Chronicles as The Lion, the Witch, and the Wardrobe, this sense of rightness, homecoming, and holidays are connected when at the name of Aslan Lucy "got the feeling you have when you wake up in the morning and realize that it is the beginning of the holidays or the beginning of summer" (65). Wilson continues later to say that "the idea of school holidays being a mere Platonic shadow of our permanent refreshment in Paradise, of our earthly homes being but a reflection of heaven" (loc. 2239). Lewis's version retrospectively attributes to this world a paler, less real sheen, so that the afterlife by comparison is the greater reality. Lewis develops this theme in The Great Divorce, in which the living appear ghostly to those in the afterlife, because that world is so much more real than the world of the living. Already Lewis is preparing his reader for his ultimate verdict that all life, according to his theology, is but a shadow of a truer, eternal reality; he draws attention to the future comparison by making Narnia seem more real than the England the children come from. Against the backdrop of the "beastly Hole" that is London according to Digory (The Magician's Nephew 10), Narnia seems to be a greater, more potent reality; it contains a life more colourful and more real. Even the apple that Digory brings back to this 
world to cure his mother seems to glow with an other-worldly "brightness": it throws "strange lights on the ceiling" and smells as if "there was a window in the room that opened on Heaven" (167).174

As it turns out, even Narnia is only a shadow-reality, not the true form. At the end of The Last Battle (1956), many of the characters are killed, the Pevensies (sans Susan) in a train crash in our world (though it is never clear whether Jill and Eustace were aboard that train and died there, or were first summoned to Narnia and died afterwards in the final battle of Narnia). Several characters meet their death at the stable door (reminiscent of the stable where Christ was born ${ }^{175}$ ), when they enter to encounter the demon Tash. The door transforms, however. The stable seems to melt away so that the door, looming larger than before, stands alone on the grass (132). Finding themselves on the other side of the door, the characters discover that they feel youthful and whole - Edmund no longer feels an old knee injury, and Digory and Polly feel that their aged bodies have "unstiffened" (132). The doorway of the stable had meant death for those who passed through it previously; the doorway thus becomes a physical embodiment of the idea that death is a gateway to life eternal. Once reunited on the other side (Digory, Polly and the others "found [them]selves" there (134) and only experience the afterlife from that side of the door), the Narnia they knew fades (the stars fall out of the sky and a great wave takes over the whole land). They realise that the land they've come into greatly resembles their beloved Narnia, but looks somehow more real. Wilson accounts for this Platonic impulse in Lewis by saying that he "has attempted [...] to account for our sense that we do not belong in this world, that we are pilgrims and strangers here, homesick for another place where one day we shall truly be ourselves" (loc. 50). ${ }^{176}$ Digory realises that the Narnia they knew

was only a shadow or a copy of the real Narnia which has always been here and always will be here [...], only a shadow or a copy of something in Aslan's real world. [...] And of course it is different; as different as a real thing is from a shadow or as waking life is from a dream." (The Last Battle 160-61)

This rebirth into an improved reality is a connecting thread that runs throughout the Narnian narrative, and many of Lewis's other books. ${ }^{177}$ It is paradise lost and regained over and over

\footnotetext{
${ }^{174}$ The tree (which grows from the seed of that apple) echoes the tradition of the Eden tree becoming the cross of Christ, and is associated with the Tree of Life in the New Creation of Revelation 22:2. See Barbara Baert, A Heritage of Holy Wood: The Legend of The True Cross in Text And Image (2004).

175 Lucy points this out in so many words: "In our world too, a stable once had something inside it that was bigger than our whole world" (134). In this instance, this is a symbol that is not very defamiliarised. ${ }^{176}$ Lewis is very aware of his indebtedness to the influence of Plato's concept of shadows of reality in the allegory of the cave. Lewis even has Professor Kirke exclaim, "It's all in Plato, all in Plato: bless me, what do they teach them at these schools?" (The Last Battle 161).

177 Interestingly, Lewis uses this idea of shadow-realities in The Silver Chair (1953), but this time it is inverted. The Lady of the Green Kirtle, another Witch, shows the shadow-reality from the shadowy side. She has captured Jill, Eustace, Puddleglum, and Rilian in her underground kingdom, and attempts to
} 
again. Our world, real and fallen, is lost to the Narnian 'greater reality'. As Spufford writes, "Narnia, of course, was not supposed to be Heaven. It was more like an imaginary other island, farther out than ours perhaps, where longing could be briefly stabilized. What could only be longed for in this world would be possible in Narnia" (99). And ultimately, of course, even Narnia is lost at the end in order to find the greater reality of Aslan's own country. Lewis is literalising the prophecy of the "new heavens and a new earth" where "the former shall not be remembered" (Isaiah 65:17). "Narnia is destroyed," says Wilson, "and then remade for eternity" (loc. 4099).

\section{The Paradox of Being Born Again: Death without Dying}

Strikingly, the promise of life after death is not the first and foremost reason for hopefulness in either Tolkien's or Lewis's fantasy worlds. The theme of being in-flux or 'becoming' has already been addressed in my previous chapters; in the cases that follow, there is something more deliberate and ultimate about the transformations of the characters. The characters in these examples are not resurrected, but are transformed, 'as if reborn.' Tolkien and Lewis have written stories that recall Christ's conversation with Nicodemus in John 3:3: "Except a man be born again, he cannot see the kingdom of God." Tolkien and Lewis turn death into resurrection, but they go on to defamiliarise the model of resurrection put forward by Christ, to portray a rebirth into a transformed, glorious body (cf. Philippians 3:21). Christ's resurrected body still bore his scars and wounds; Tolkien and Lewis, however, resurrect their characters so that they are renewed. William Gray associates this impulse with the "motif of 'stirb und werde' [die and become]" (Gray 2).

One of the ways they do this is through a metaphorical rebirth through the frame narrative of characters returning to their starting point changed, such as is experienced by Bilbo

bewitch them into doubting the existence of all they had known - Narnia, Aslan, any other world but her own, even the existence of the sun. She scoffs at their attempts to explain: "Hangeth from what, my lord? [...] You can only tell me it is like a lamp. Your sun is a dream; and there is nothing in that dream that was not copied from the lamp. The lamp is the real thing; the sun is but a tale, a children's story" (153). Because the reader knows the sun exists, despite her scoffing and the "nursery nightmare version of Lewis's debate with Miss Anscombe" (Wilson, loc. 4065) aside, Lewis has set the reader up for what Marilynne Robinson calls "the sound human intuition that there is something beyond being as we experience it in this life. What is often described as the transcendent might in some cases be the intuition of the actual" ("Theology" 212). It is worth noting that Lewis is not so presuming (after the Anscombe debate) as to state the matter as confidently as Robinson does in calling it a 'sound intuition'. The children find they cannot hold to a memory or even prove the existence of the world they've come from, and so Puddleglum resorts to intuition alone (if not simply loyalty), declaring that he is "on Aslan's side, even if there isn't any Aslan to lead it" (156), and behave "like a Narnian [...] even if there isn't any Narnia" (157). Ultimately, before they even reach The Last Battle, Lewis has already opened the reader's mind to the possibility of other realms, or something 'beyond' even if their existence cannot be proved. 
in The Hobbit, the hobbits in The Lord of the Rings, and the children in The Lion, the Witch and the Wardrobe, Prince Caspian, and The Silver Chair. This kind of framing, typical of almost all fictional characters who go on a journey or have an adventure, which emphasises the rebirth of the characters, defamiliarises resurrection motifs so that they are applicable even to characters who have not actually died (and so don't need to be reborn). Bilbo, for instance, goes from a "little fellow bobbing on the mat" (The Hobbit 30), and fainting dead away at the mention of risk, to being named by the Elvenking "more worthy to wear the armour of elf-princes than many that have looked more comely in it" (258). Bilbo's transformations are described casually at first - "Already he was a very different hobbit from the one that had run out without a pockethandkerchief from Bag-End long ago. He had not had a pocket-handkerchief for ages" (204). Bilbo's growing distance from his old self becomes increasingly apparent: "he knew only too well what it was to be really hungry, not merely politely interested in the dainties of a well-filled larder" (181). While these changes are also part of the quest narrative trope, which depicts extraordinary events bringing about extraordinary change, quest narratives themselves follow a kind of resurrection trajectory of normality, to chaos (being the journey or death), to a return to normality - albeit a different kind of normal. Many classical quest myths, furthermore, explicitly feature a katabasis (or descent into the underworld) and return (or anabasis, ascent). ${ }^{178}$ Bilbo, for example, ultimately receives the accolade of "O Bilbo the Magnificent" at the close of his journey by the Elvenking (277); however, Bilbo's transformation is subtle enough that the effects of this rebirth are only felt, or at least recognised as such, in the final leg of the journey: the changes in him become obvious as he re-enters his old context. Gandalf particularly notices it as Bilbo breaks into song in sight of his own little hill in the Shire: "Gandalf looked at him. 'My dear Bilbo!' he said. 'Something is the matter with you! You are not the hobbit that once you were'" (284). Yet Bilbo's unexpected talent for near-escapes, burglary, and cunning negotiation in battle is no longer required of him (nor known to his neighbours). To all outward appearances, he is the homely hobbit he has always been: the Tookish, adventurous part of him giving way again to the homely Baggins personality (278). But Gandalf notices the change, and the hobbit who returned is not the hobbit who left. The transformation motif is foregrounded, here, preparing the reader for the transformative resurrection of characters later on.

In Lewis's fiction, returns are also clearly expressive of rebirth. The journey through the portal of the wardrobe can be seen as a kind of birth or rebirth. This is especially clear at the return of the children through the wardrobe at the end of The Lion, the Witch and the Wardrobe. Having spent much of the story as children, the children go on to live to adulthood in Narnia.

178 Examples include Orpheus and Hermes going into Hades to rescue (or try to rescue) Eurydice and Persephone respectively; and Dante's Inferno is a quest entirely centred on the katabasis of Dante. 
Their habits and mannerisms, even their speech, adapt to the medieval nobility of the Narnia they grow up in. As the next book, The Horse and His Boy, makes clear, the kings and queens of Narnia have known histories and wars, established relations with neighbouring nations, even negotiated marriage proposals. Yet when they unwittingly stumble back through the wardrobe door,

they were no longer Kings and Queens in their hunting array but just Peter, Susan, Edmund and Lucy in their old clothes. It was the same day and the same hour of the day on which they had all gone into the wardrobe. (The Lion, the Witch and the Wardrobe 170)

Although no longer a radical twist in children's literature, we should not forget that in the world of the story, the experience for the children of being returned to exactly what they were when they left is unusual and potentially rather jarring. Do the children maintain some of their memories of having been adults, even as they grow into adolescence all over again? Perhaps this is Lewis's conceptualisation of conversion in the religious sense, the idea of everything changing and yet everything remaining the same. As he writes elsewhere: "A man who has been in another world does not come back unchanged" (Perelandra 152). As with Lewis's 'enchanted woods' analogy, Spufford describes a similar effect on the reader, that

once opened, the door would never entirely shut behind you either. A kind of mixture would begin. A tincture of this world's reality would enter the other world, [...] while this world would be subtly altered too, changed in status by the knowledge that it had an outside. (85-86)

The children would likely have retained some of the attitudes, some of the lessons learned, even perhaps some of the maturity acquired in the other world. At the close of the book they seem to slip seamlessly into the children they were, reliant on the Professor to answer their questions. The framing of the journey through the wardrobe allows them to live (to adulthood in Narnia), and live again when they come out. Their death and rebirth are metaphorical, but nevertheless absolute. They are the same, but renewed.

The 'rebirth' of the London cabby in The Magician's Nephew suggests the restoration of life that Digory wants for his mother. Before Digory's mother is cured, the cabby becomes an image of the kind of rebirth that reverses the effects of a fallen world: he loses any trace of unpleasantness he's picked up by being in the world, and is renewed. He is a simple man, who "never 'ad much eddycation, you see" (129), making a rather paltry living in London, who finds himself elected to rule Narnia with his wife. The children observe his transformation even as he stands there: "[a]ll through this conversation his voice was growing slower and richer" (95). Although this transformation is not exactly a 'rebirth', if it expresses Lewis's conceptualisation 
of conversion, it is the form of 'rebirth' suggested by Jesus to Nicodemus. Two days later at their coronation the cabby and his wife are unrecognisable:

But it was neither hair nor clothes that made them look so different from their old selves. Their faces had a new expression, especially the King's. All the sharpness and cunning and quarrelsomeness which he had picked up as a London cabby seemed to have been washed away, and the courage and kindness which he always had were easier to see. Perhaps it was the air of the young world that had done it, or talking with Aslan, or both. (154-55)

This 'rebirth' seems to take years off the couple, removing the bitterness of hardship and confirming all that is excellent. Quite apart from the lingering influence of death - almost in the midst of it, one might say (Digory's mother still lies ill at this point) - there springs an unquenchable, formidable sense of potent, infectious life. Lewis suggests that this hope of life undoes the curse of death.

The Paradox of Death: O Death, Where is Thy Sting?

Turning to instances of resurrection proper, it is notable how Tolkien and Lewis defamiliarise even this. It could be argued, indeed, that like Lewis's cabby, Gandalf seems to undergo a thorough resurrection, or rebirth, without even properly dying. For one thing, Tolkien defamiliarises Gandalf's resurrection by deliberately avoiding using such definite wording to define it. As he is pulled from the bridge, Tolkien writes not that Gandalf perished but that he "slid into the abyss [...] and was gone" (The Fellowship of the Ring 331). The Fellowship also use euphemisms to describe their loss, saying "Gandalf the Grey fell into shadow. He [...] did not escape. [...] he fell" (355). Yet for all this, they treat his loss as a death, so that Gandalf's doom cannot be gainsaid. After Gandalf's passing, they number themselves as eight, no longer nine (343), and describe the Balrog that took him "of all the elf-banes the most deadly" (356, emphasis mine) so that his fate is not exactly in question. He has died, or something very nearly like it. Later, Gandalf himself describes his experience: "[ $t$ ]hen the darkness took me, and I strayed out of thought and time, and I wandered far on roads that I will not tell. Naked I was sent back - for a brief time, until my task is done" (502, emphasis mine). Significantly, Gandalf's journey took him both to a fiery hell and through the utter annihilation of death, and he acknowledges he was 'sent back,' implying his removal from the world of the living. In spite of all this, it is difficult to say he was 'resurrected,' for he is not the same person:

"Gandalf," the old man repeated, as if recalling from old memory a long disused word. "Yes, that was the name. I was Gandalf." [...]

"But you are all in white!" "Yes, I am white now," said Gandalf. "Indeed I am Saruman, one might almost say, Saruman as he should have been." (The Two Towers 495) 
In this scene, the completeness of Gandalf's rebirth can be observed in even the narrator's reluctance to name him. Legolas names him Mithrandir, Gandalf's Elvish name, which is the reader's first clue as to the identity of the man they assume to be Saruman. And yet the narrator continues the disconnect, calling him 'the old man.' The resurrection of Gandalf follows his literal fall, into the dark chasms of Khazad-dûm, and a literal ascent back to the world of the living, providing a vision of fall and redemption, and an image of how Gandalf's journey mimics the trajectory of Christ's. There is something hot and hellish about the place that Gandalf eventually falls to: "His fire was all about me. I was burned. Then we plunged into the deep water and all was dark. Cold it was as the tide of death: almost it froze my heart. [...] Yet it has a bottom, beyond light and stone" (The Two Towers 501). In this we may observe a fairly literal reimagining of the "Apostles' Creed" in which the Christ "was crucified, died, and was buried; / he descended to hell. / The third day he rose again from the dead. / He ascended to heaven" (Church of England): death and descent followed by life and ascent. He is a version of himself that is not only resurrected but thoroughly renewed, from the garments of grey to white and therefore higher in the hierarchical order of wizards. He has been reborn as if someone else - as if Saruman. The complexity of this revival and new life is not limited to the redemption and restoration of Gandalf the Grey to a superior version of himself; it expands to encompass the restoration of Saruman as well: Gandalf becomes Saruman as he ought to have been, Saruman bettered. He fulfils the original purpose of one who fell. Gandalf's ascension, though similar to Christ's in glory (as the creed states, he "is seated at the right hand of God, the Father Almighty"), in this way develops a new strain in a familiar theme: that of becoming, or at least fulfilling, the role that the enemy has corrupted. In ascending rank from grey to white, Gandalf becomes a greater version of himself, and simultaneously a greater version of Saruman, formerly "the White" (The Fellowship of the Ring 48), in order to fulfil the office that Saruman has neglected. It is a reclamation of authority and of hope. As Gandalf says to them, "We meet again. At the turn of the tide. The great storm is coming, but the tide has turned" (The Two Towers 495), for no weapon could now hurt him, and Saruman is almost vanquished (if not already replaced). This is death and resurrection, but not as we have seen it either in Christ or in the imagery of Revelation.

Lewis is equally imaginative in his treatment of resurrection as rebirth. He describes it as a kind of running backwards towards youth. After the death of the aged Caspian in The Silver Chair (1953), Jill and Eustace witness his resurrection into his renewed form:

And the dead King began to be changed. His white beard turned to grey, and grey to yellow, and got shorter and shorter and vanished altogether; and his sunken cheeks grew round and fresh, and the wrinkles were smoothed, and his eyes opened, and his eyes and lips both laughed, and suddenly he leaped 
up and stood before them - a very young man [...].

"But," said Eustace, looking at Aslan. "Hasn't he - er - died?"

"Yes," said the Lion in a very quiet voice, almost (Jill thought) as if he were

laughing. "He has died. Most people have, you know. Even I have. There are

very few who haven't."

"Oh," said Caspian. "I see what's bothering you. You think I'm a ghost, or some nonsense. But don't you see? I would be that if I appeared in Narnia now: because I don't belong there any more. But one can't be a ghost in one's own country". (202-03)

Caspian is now alive, more alive it would seem, than he has ever been. And his resurrection is part of his homecoming, or at least, he makes it apparent that his resurrection takes place somewhere (that is, in Aslan's country) that feels more his own country than his native Narnia had ever been to him. He experiences a renewal of his own self, not just a renewal of days like Tolkien's Théoden. ${ }^{179}$ Milbank asserts that resurrection is physical - "[w]ithout the whole body [...], it is unclear what it is that can be released from the land of the dead at all" ("Death and Duality" 104). This may explain why Lewis is at pains to describe the resurrection of Caspian's corpse in richly physical detail. Indeed Lewis demonstrates a deep respect for physical embodiment (rather than a kind of dissolving of flesh into pure spirit) which is in keeping with the doctrine of the resurrection of the body - as in Philippians 3:21, the "vile body" is "fashioned like unto his [Christ's] glorious body". He describes it from the perspective of an admittedly scornful Screwtape at the end of Screwtape Letters when Wormwood's patient has died. Even in his disgust, Screwtape describes the transition to the afterlife in terms both crude and poetic, from "as if a scab had fallen from an old sore, as if he were emerging from a hideous, shell-like tetter, as if he shuffled off for good and all a defiled, wet, clinging garment" (121-122), to the ecstatic relief of "this final stripping, this complete cleansing" (122). What Lewis describes as a physical resurrection is also a restoration: not only is the elderly Caspian brought back to life, he is brought back to his prime - which in (admittedly speculative) theological terms is perfectly traditional and familiar.

\footnotetext{
179 Caspian's transformation is reminiscent of Théoden's recovery as depicted by Peter Jackson in the film The Lord of the Rings: The Two Towers (2002), although Tolkien's textual depiction is somewhat understated in comparison with Lewis's of Caspian. From "so bent with age that he seemed almost a dwarf" Théoden becomes a man of pride and power: "He drew himself up, slowly, as a man that is stiff from long bending over some dull toil. Now tall and straight he stood, and his eyes were blue as they looked into the opening sky" (515). Fran Walsh's screenplay for Jackson's film makes more of the moment: made ancient beyond his years, when Gandalf's restorative power confronts him, his eyes go from milky and blind to clear and alert, his wizened, papery skin is restored to its youthful vigour and complexion, and his straggling white beard reverts to a well-kept golden. He de-ages in a shot of ingenious computer imagery, very like what Caspian does here. This visualisation in Jackson's The Two Towers film may have been influenced by the Caspian passage in Lewis. Théoden is returned from the dead, as it were, in Jackson's film, transformed from the corpse-version of himself into the hale, warrior king he was.
} 
Caspian's resurrection is, moreover, the first hint that Lewis gives in the Chronicles of life after death for the ordinary person. ${ }^{180}$ Caspian's restoration chimes in with an important touchstone of both fantasy fiction and theology, namely the defeat of death (which is distinct from cheating death, as discussed above). With the notable exception of Digory, neither death nor Heaven (characterised as Aslan's country) has featured very prominently in the minds of the children. The mouse Reepicheep is the only one to go looking for Aslan's country, while the others have only vague ideas about one day being there, too. For Lewis, the promise of an afterlife is not the point. Sheldon Vanauken quotes a letter Lewis wrote him about the promise of Heaven in which Lewis explains, "Note that life after death [...] was itself a late revelation. God trained the Hebrews for centuries to believe in Him without promising them an after-life [....] What wd. Be a bribe if it came first had better come last" (92). It is perhaps no accident then that the 'late' revelation only comes in the third Narnian Chronicle published, The Voyage of the Dawn Treader (1952), when Lucy and Edmund's conversations with the Lamb at the edge of the world reveal the possibility for all to gain Aslan's country (186). Lewis hints at an afterlife through Caspian's restoration to eternal life in The Silver Chair, as we have seen, but it is only explicitly dealt with in The Last Battle: the main characters gain entry to Aslan's country (Lewis's version of Paradise) and briefly invite the readers' gaze into it. For the Narnians, at least those who have been 'converted,' death is made redundant or irrelevant. Here at last is Lewis's answer to the problem of death, to the theology of the Fall, the problem of Adam. Death is no longer to be feared or thought of as an ending at all. Life is no more than an afternoon on one side of the wardrobe or stable door, and real life, the greater reality, lies on the other side.

\section{Conclusion: If Death is Irrelevant, Endings are Irrelevant Too}

Finally, if by this doctrine death is rendered irrelevant, 181 then Tolkien and Lewis extend this concept so that even their own narratives become "only the beginning of the real story [...], Chapter One of the Great Story which no one on earth has read: which goes on forever: in which every chapter is better than the one before" (The Last Battle 173). Common to both authors is an unwillingness to treat the end of story with any conclusive finality. 'Happily ever afters' are hinted at, but often undercut by an implication that the story is not really over. The story has merely returned to an Eden-like beginning, which is not quite the same as Revelation's evocation of the New Creation. In The Return of the King, the replanting of a new sapling of the

180 Because Aslan is a Christ-figure, his resurrection is treated as unique.

181 This is not to gainsay previous discussions on the importance of dying well. Tolkien and Lewis would agree that the story matters: how one lives or dies is important (as seen in Tolkien's "Leaf by Niggle" for example), but only as a prelude to what is to come. Death is made irrelevant because what is ultimate comes afterwards. 
White tree of Gondor is heavy with symbolism of a new age, a new Eden, and Revelation's New Creation itself. Indeed, as Milbank points out, this tree evokes both the Genesis Tree of Life and the tree of the New Creation "that gives life to the city", itself a "tree of life' in the new heaven and earth of Revelation 21-22" (Chesterton and Tolkien as Theologians 108). Yet Tolkien is not using this allusion to Paradise to tie up loose ends in his narrative; he is beginning another story. A new tree is more of a beginning than an ending. Sam, moreover, carries the seed of the Elvish mallorn tree that Galadriel gave him, still to be planted. If anything, the eschatological significance of Gondor's paradisal tree appearing at the end of the quest is undercut by the fact that the narrative is very clearly unfinished. As Joy Chant notes in "Niggle and Númenor," Tolkien "leads [his audience] down through the consummations of victory, the weddings and the partings, the typing of ends, the counting of the cost: a gentle diminuendo culminating in the Scouring of the Shire (a neat restatement in miniature of the story's theme)" (162). The whole epic narrative ends, indeed, not with Frodo's final goodbye as he departs at last from the everpresent Sam at the Grey Havens, but with Sam, the humblest character returning to the humblest home, and resuming a humble, uneventful life. This ending is neither comic nor bathetic. Rather, it has a similar effect on the reader as might be imagined for the Pevensie children tumbling out of the wardrobe and back into the real world: the adventure has been allencompassing and transformative, for both characters and readers, and yet there is a very real, daily existence to be returned to.

There is a sense of longing, even dissatisfaction, in this kind of leave-taking. Tolkien seems to be pushing the reader's imagination into the realm of the beyond: if the ending is not satisfying, what would make it so? Although Tolkien alludes to closure, he undercuts it: the quest is finished, the doom which was hanging over the narrative is vanquished, but there nevertheless remains a sense of loss and a setting right to be done. This is something that Bowman has noted, reflecting that Tolkien's resistance to the "much-discussed issue of closure" in that both The Hobbit and The Lord of the Rings showcase "the problem of beginning anew after closure has apparently been achieved" (274). The displacement of Faramir as the final Steward, the continued vigilance over all the lands of Middle-earth, even the scouring of the Shire, and final dismissal of Saruman - all of these events prevent the narrative from ending on the satisfying high point of Aragorn's coronation. Yet, as Milbank points out, even Aragorn's ascension "is only historical and mortal, not immortal and divine" (109). The king may have returned, but he will go again. Most of the Fellowship are still standing, but they must be disbanded. The victory is won in Mordor over Sauron, but there is still evil, in the person of Saruman himself, to be vanquished in the Shire. 
Even as Tolkien evokes Revelation's heavenly, paradisal New Creation, he situates it very firmly in the context of a fallen world: his New Creation tree is only an image of the Tree to come. Once again, Tolkien is not so much projecting theology, as proposing ways in which it might be imagined - but he never goes so far as to describe the final result himself. Milbank speculates that this is precisely how Tolkien engages his readers to make sense of the connections and paradoxes for themselves:

At the end of The Lord of the Rings it is up to the reader to hold the natural and supernatural ends of the characters together. And our own desire for a reunion of the characters beyond the separations of the last chapter is to provoke in us a longing for a happy ending that does not negate but fulfils the 'natural desire for the supernatural' [...] Tolkien goes even further than Augustine's autobiography that describes a soul yearning for the divine, by making his reader perform this desire for the transcendent, although in some cases - indeed many - the reader may not know what he or she longs for. (112)

All readers may not, as Milbank suggests, be consciously desiring the reunion (in this world or the next) of the hobbits after the poignant separation at the Grey Havens; however, by the fact that there is grief at separation Tolkien inversely suggests that reunion, in whatever form, is desirable. The happy ending is somewhat undercut by this. And again, the impermanence of Aragorn's reign is the only flaw in its perfection, as far as the reader knows. Those who read the appendices will be familiar with Aragorn's gentle easing from this life and his succession by the grief-stricken but nevertheless immortal Arwen who cannot follow. These are anticlimactic and incomplete endings, however inevitable, to the seemingly regained paradise. Tolkien's characters seem to know this too: Sam asks Frodo, "Don't the great tales never end?" and Frodo responds "No, they never end as tales. [...] But the people in them come and go when their part's ended." (The Two Towers 712). Frodo has defeated Sauron, but he never heals from the wound inflicted by Sauron's servant. Tolkien makes his reader aware of their own desire a conclusive 'happy ending', final healing, fulfilment, closure, etc. in the story, precisely through this strategy of indefinite postponement. It is this gentle melancholy that is designed to draw the reader into a yearning for the restoration and fulfilment of all desires - fulfilment Tolkien only hints at, by trying to make the readers aware of what they long for. In showing them what is lacking, he is offering a glimpse of that evangelium he imagines. The death of Christ is for Tolkien and Lewis the prototype after which all death was modelled. Tolkien writes that "The Gospels contain a fairy-story, or a story of a larger kind which embraces all the essence of fairy-stories [....] The Birth of Christ is the eucatastrophe of Man's history. The Resurrection is the eucatastrophe of the story of the Incarnation" (62-63). ${ }^{182}$ "Art has been verified," Tolkien declares, "[t]he

182 'Eucatastrophe' is a word of Tolkien's own invention, signifying the "the good catastrophe, the sudden joyous 'turn'" in story (60). 
Evangelium has not abrogated legends; it has hallowed them, especially the "happy ending"' (63). Such eucatastrophe of life after death can be seen in the characters of Gandalf, Aragorn, Aslan, Caspian, even Théoden, and many others.

Lewis, by contrast, is more overt in his stripping away of any sense of finality from a definitive ending. For instance, he names the final chapter of The Magician's Nephew - the first book of the Narnian chronology, not the first published - "The End of this Story and the Beginning of All Others" (164). This idea of ending but endlessly beginning is an integral part of his theology: even his narratives cannot conclusively die. Thus, even narrative here hints at resurrection, rebirth and return. Professor Kirke tells the children "of course you'll get back to Narnia again some day [...] But don't go trying to use the same route twice. Indeed, don't try to get there at all. It'll happen when you're not looking for it" (The Lion, the Witch and the Wardrobe 170). In his story-telling imagery (and occasionally even through a physical doorway), Lewis teases out a paradigm of endings and beginnings where death is the entry point from this to a Greater Reality.

Tolkien and Lewis revel in the paradox of unoriginal originality, of Christ in fairy tale, of a pastiche of the familiar and the strange, of finding life in death. Death, for these authors, is both the evidence of the Fall and also the act which reverses it. Through their fiction, Tolkien and Lewis infect their readers with narrative expectations that trace the same pattern of death and resurrection as Christological doctrine, and also inspire them with a yearning for redemption in terms of restoration, return, and home. 


\section{Conclusion}

Stories leave themselves open to a much wider spectrum of interpretation than theology does. (Miller, The Magician's Book 281)

Tolkien and Lewis shared not only the reputation of being two of the twentieth century's greatest fantasy writers, they also shared a foundational belief which underpinned all their creative works. They were both firm believers in the defining elements of the Christian 'story' (or 'mere Christianity,' to borrow a Lewisian term). These included a belief in an all-creating God, in the goodness of God's creation, in the sin that humanity had inherited as a result of Adam's fall, and in the incarnation and resurrection.

They were aware, however, that they lived in a time when such belief was not only becoming less common, but was being undermined from within by new developments in scholarship and criticism that sought to 'de-mythologise' Biblical narratives - a movement they saw as reductive and theologically troubling. What to the demythologisers was fable was to Tolkien and Lewis truth - truth at more than one level. For them, faith and reality were not mutually exclusive. In order to break away from a de-mythologising script, or any reductive treatment of orthodox belief, Tolkien and Lewis used fantasy to defamiliarise, and thus to restore and reclaim, faith and Biblical doctrine. They aimed to re-mythologise fantasy, fiction, and even real life, rescuing all of these from a contempt bred by over-familiarity. Their creative work is, above all else, about engendering, and sustaining belief.

Seen in this light, their storytelling may be understood as a performance of their theology. Tolkien and Lewis saw a role for storytelling (especially the stories that no one else seemed to be telling) within the broader context of their own religious beliefs. Their fiction is dependent upon, and a manifestation of, a very present God. The "fundamental function" of subcreating, Tolkien writes, is that it is "a tribute to His [God's] potential variety" (Letters 188). In writing these stories, they were 'theorising' about artistic creation, about the nature of God and what can be known about him, and about how these things pertained to a creative writer. Tolkien and Lewis were convinced, in other words, that their creativity served a God-given purpose, and that their fiction could indeed act as worship: they saw themselves as imaging the infinite variety of God.

Fully aware that these worlds were invented, 'made up', and in a sense 'lies,' they undertook to use these 'lies' to tell truth (or at least, truth as they understood and believed it). This is the essential point: for Tolkien, fictions are not lies because even the made up is entwined in the true. Tolkien explains in his poem "Mythopoeia" that all human inventions, 
especially speech and mythology, have some truth beyond the surface: "The heart of Man is not compound of lies / but draws some wisdom from the only Wise, / and still recalls him" (ll. 5355). In so saying, Tolkien asserts that all tales hearken back to God, and recall the good creation of a good Creator (from whom, Tolkien believes, all goodness derives).

Perhaps for this reason, both Tolkien and Lewis make considerable efforts to encourage belief in fiction. Both authors use conceits such as the found manuscript (such as Bilbo's and Frodo's claims to authorship of Tolkien's The Hobbit and The Lord of the Rings), according to which the authors are able to situate themselves as editors or scribes - but, as is the case with Lewis in The Screwtape Letters, decline to account for the provenance of the accounts. Their prefaces and prologues are written as if the letters are authentic documents. As Carpenter observes,

Tolkien cast his mythology in this form because he wanted it to be remote and strange, and yet at the same time not to be a lie. He wanted the mythological and legendary stories to express his own moral view of the universe; and as a Christian he could not place this view in a cosmos without the God he worshipped. (J.R.R. Tolkien: A Biography 91)

Carpenter shows that Tolkien never makes any claims to fact in his fictions that could then be exposed as false (such as locating his mythology geographically in our world). Rather he synthesises what he creates with what he believes. Shippey writes that for Tolkien, "fantasy in no way compromised his religion" (J.R. R. Tolkien: Author of the Century loc. 5077): "Not only are fantasy and reality harmonized [...], so also are fantasy and faith" (loc. 5077). This analysis holds true for Lewis, too. Lewis's idea that imagination is the organ of meaning (see "Bluspels and Flalansferes" 157) has been noted in previous chapters; he further argues that myth is the organ for reality. For Lewis, myth is capable of embodying truth in a way that doctrinal statement cannot. He writes that in enjoying a myth,

you are not knowing but tasting; but what you are tasting turns out to be a universal principle. [...] It is only while receiving the myth as a story that you experience the principle concretely. When we translate we get abstraction or rather, dozens of abstractions. What flows into you from the myth is not the myth but reality (truth is always about something, but reality is that about which truth is) and, therefore, every myth becomes the father of innumerable truths on the abstract level. ("Myth Became Fact" 58)

For these reasons, both authors strove to elicit what Tolkien called "Secondary Belief," that is, belief in a "Secondary World which your mind can enter. Inside it," Tolkien elaborates, what the 
author relates "is 'true': it accords with the laws of that world. You therefore believe it, while you are inside it" (“On Fairy-Stories” 36). ${ }^{183}$

In creating an atmosphere of 'truth,' Tolkien's strength was in the richness and complexity of the worlds he constructed. Tolkien took on the tone and atmosphere of the Norse mythologies he so enjoyed, immersing the reader in an ancient foreign culture, albeit one of his own creation. ${ }^{184}$ In presenting his fiction as a 'real' secondary world, Tolkien was conscious of the risk that sub-creation's spell might be broken, as has already been said, "by an obtrusive narrator's voice, or by any nod or wink or allusion to readers or hearers referring them back to the Primary World" (Scull and Hammond 982):185 this explains his measured attempt to firmly ground his stories in (alternative) reality. He does not explain how Bilbo's and Frodo's chronicles fell into his hands, but determinedly sets both hobbits forth as the authors. Several pages of the prologue to the Second Edition of The Fellowship of the Ring are devoted to the origins of this (fictional) archival material and its preservation; he names several protagonists as particular custodians - King Elessar (Aragorn), for example, authorises copies to be made (14) - and devotes an appendix to a translation note of the work into "Common Speech." Lewis, by contrast, does not commit himself to Tolkien's quasi-scholarly framing. Lewis is content for his stories to take on the nature of a fable. There is no found-manuscript conceit in Narnia; entry into faerie is the result of a transportation device, be it a wardrobe, a painting, or a doorway in a wall. Where Tolkien insists on the realism of his fantasy world, Lewis emphasises the 'magical' nature of Narnia. He remains, however, preoccupied with 'real-world' logic - conveyed through the mutterings of Professor Kirke in the Narnia books and the Fox in Till We Have Faces - that allows for the existence of other worlds. In this way, the foundations are laid that establish what Tolkien would call an "inner consistency of reality" ("On Fairy-Stories" 43).

\footnotetext{
183 This Secondary Belief is distinct from Coleridge's 'willing suspension of disbelief,' which suspends judgement and even expectation of plausibility (cf. Chapter 14 of Biographia Literaria). It was with that word 'willing' that Tolkien took issue.

184 This is notwithstanding Tolkien's temporary lapses into a lighter, more comic tone in The Hobbit. He responds to a reader's query about the change in tone, as has been pointed out above, even within the progression of The Hobbit itself, saying: "The generally different tone and style of The Hobbit is due, in point of genesis, to its being taken by me as a matter from the great cycle susceptible of treatment as a 'fairy-story', for children. [...] [T] he tone and style change with the Hobbit's development, passing from fairy-tale to the noble and high and relapsing with the return" (Letters 159). In his recommendation of The Hobbit, Lewis comments that although it appears comic, there is a gravity in it (which would come to be thought of as characteristic of Tolkien's style). Lewis writes, "Alice ['s Adventures in Wonderland] is read gravely by children and with laughter by grown-ups; The Hobbit, on the other hand, will be funniest to its youngest readers, and only years later, at a tenth or twentieth reading, will they begin to realise what deft scholarship and profound reflection have gone to make everything in it so ripe, so friendly, and in its own way so true" ("The Hobbit" 111).

185 This is interesting, when one considers anachronisms such as comparisons to express trains and telescopes, as mentioned in my third chapter.
} 
As my examination of their work has demonstrated, one of the chief strategies Tolkien and Lewis employed for this fiction-making is defamiliarisation. Defamiliarisation brings the wonder of a new thing to bear upon a familiar thing; it estranges familiar theology in order to reintroduce it to the imagination. Because their fictions are fiction, they are allowed to be playful; they liberate readers from the prescribed responses one associates with doctrine as such.

Defamiliarisation is an inherent part of immersion within an invented world, and thus a constant part of Tolkien's creative vision and writing, though he did not know the technique under that name. The whole of Tolkien's creative output is single-minded, consistent in narrative and tone, and governed by his conceptualisation of Middle-earth. His attention to detail is evident in the enormous scholarship he put into the background material. In fact, his legendarium is in some ways born of his interest in language creation (see Plimmer et al. 32). Language creation was something at which Tolkien excelled, unlike Lewis whose linguistic inventions are confined to a few unremarkable words and rules in Out of the Silent Planet. Tolkien did not make up a language to lend authenticity to the world he had created; instead, the languages he made necessitated a legendarium to support them. He writes that he "discovered, as others have who carry out such inventions to any degree of completion, that a language requires a suitable habitation, and a history in which it can develop" (Letters 375). Tolkien expresses a sense of being directed by his characters and world, rather than the other way around. He writes, for instance, during the creation of The Lord of the Rings:

A new character has come on the scene (I am sure I did not invent him, I did not even want him, though I like him, but there he came walking into the woods of Ithilien): Faramir, the brother of Boromir - and he is holding up the 'catastrophe' by a lot of stuff about the history of Gondor and Rohan (with some very sound reflections no doubt on martial glory and true glory): but if he goes on much more a lot of him will have to be removed to the appendices - where already some fascinating material on the hobbit Tobacco industry and the Languages of the West have gone. (79)

The characters, and specific histories of Middle-earth seem to emerge independently, and their part in the story becomes apparent to Tolkien only later. His story emerges organically (almost as a by-product) from a single world he has meticulously created and filled.

Both Lewis and Tolkien exhibit an extraordinary talent for imaginative world-building, albeit in different ways. A wide range of defamiliarising technique is equally apparent in Lewis's works. Lewis's writing ranges widely across genres, is intended for various audiences, and borrows (somewhat eclectically) from a variety of sources. Lewis was a voracious reader, and 
almost willingly influenced by what he read. ${ }^{186}$ The results of Lewis's wide-ranging literary taste are evident in the variety of tale he was able to tell. His "repertoire" of language styles has been called "most dazzling" by Adey, as Lewis "shifts at will from plain speech" to "Morrisian medieval language”, "Arabian Nights rhetoric", "hierarchic-feudal language”, "mumbled bureaucratese", "Shakespearian reproof", "chivalric speech", "romantic, northern expressions", and even "stage cockney" (191-2). For Francis Spufford, "Narnia is patchwork" (The Child that Books Built 100). Unlike Tolkien, in Narnia Lewis "mixed together, with joyful promiscuity, everything, from a thousand sources, that had given [him] delight" (100), and "jumbled up stuff that [Spufford had] associated with different kinds of story" not just different stories (100). For A. N. Wilson, the immense difference in Tolkien's and Lewis's styles came down to the way in which their worlds were imagined: He says that

[t]he fascination of Tolkien is that his was a finished and enclosed imagination. His world, with its creatures, gods, angels, languages, lost tales and civilizations, is as complete as the 'real' world; perhaps more so. There is never an intrusive moment in Tolkien of two worlds jarring together; no hint, for example, that the creation story in The Silmarillion might relate to anything we have read [...]. Lewis's Narnia books are quite different. Their whole theme is the interpenetration of worlds, and he poured into them a whole jumble of elements, drawn from his reading, and the world he was inhabiting when he wrote the books. (C. S. Lewis: A Biography loc. 4054)

Apart from Biblical doctrine and exegesis, critical literature, academic history, and medieval scholarship, Lewis also wrote dream parable (The Great Divorce), 'Greek' myth (Till We Have Faces), children's fantasy, ${ }^{187}$ science fiction (the Space Trilogy), Arthurian legend (particularly evident in That Hideous Strength), and Hellish epistles (Screwtape Letters). For the purposes of defamiliarisation, Lewis borrowed from fairy tale, animal fable, late Edwardian and Victorian children's literature, Romanticism, pagan mythology (classical and Scandinavian), chivalric romance and Arthurian legend, the "Blyton four" adventure genre, 'oriental' tales, and science fiction. Lewis noted the impact that the Beatrix Potter's animals had upon his boyhood imagination (Surprised by Joy 16), and even at an early age was combining these into tales of his own creation, so that "dressed animals" were "knights-in-armour", riding out "in complete mail to kill not giants but cats" (16). Lewis once wrote that his initial disinclination for the gospels arose from their lack of "the mythical wealth of the Pagan world around them" (Surprised by Joy 188). Walter Hooper summarises this point from Lewis's Pilgrim's Regress (1933), writing that

186 Tolkien, in fact, came to think Lewis "was a very impressionable man" (Letters 361), and disapproved of the influence of Charles Williams on Lewis's writing, particularly in That Hideous Strength. 187 The Chronicles of Narnia comprises enchanted adventure (The Lion, the Witch and the Wardrobe), medieval crusade (Prince Caspian), sea-faring odyssey (The Voyage of the Dawn Treader), the pilgrimage quest (The Silver Chair, also comprising the lost prince), run-away adventure (The Horse and His Boy), journey to the land of youth (The Magician's Nephew), apocalypse (The Last Battle). 
Lewis believed God had given Jews the 'Rules' and set them on a 'Road,' whereas “He gave the Pagans 'pictures'” (569). Even as Lewis conceded that "nothing else in all literature was just like" the gospels (Surprised by Joy 188) as "the summing up and actuality" of all religion and philosophy (189), his creativity seems to address itself first to a perceived lack of intensely visual mythological beauty ("It All Began With a Picture" 79).

Significantly, while neither Tolkien nor Lewis provides a definitive ending to their stories, both provide positive notes with which to finish. These are notes of homecoming, of restoration, of new beginnings, of growth, and of hope: notes that rest, in short, on their beliefs about redemption, resurrection, and heaven. Even so, their fiction contains a note of yearning, in keeping with the Christian belief that ultimate restoration lies outside of this life, in the New Creation, or Heaven. Each author hints at this unarticulated longing, believing their sense of a fallenness in the world and their longing for its remedy to be the common experience of humankind. For Tolkien, the principle of a 'happy ending' or 'eucatastrophe' should not only be "a 'consolation' for the sorrow of this world" but also "a far-off gleam or echo of evangelium in the real world" ("On Fairy-Stories" 62). Thus, while his stories may not conclude with an unequivocally happy ending, he invariably hints at a fundamental hope which underlies all, even as goodness is embodied in apparently weak characters. Tolkien's fiction establishes the brokenness of a world which, although desperately beautiful, nevertheless longs for an ultimate, more complete redemption. Lewis's first sense of this longing - for Novalis' Blue Flower, the faroff gleam of Joy in this world - was largely altered by his conversion. At the end of his spiritual memoir, Surprised by Joy, he writes: "the subject [the pursuit of Joy] has lost nearly all interest for me [...]. It was valuable only as a pointer to something other and outer" (190). Once he had found this pursuit answered in the Christian faith, he turned his attention to what it pointed towards. Subsequently, one finds that the longing in Lewis's texts is always fulfilled and loose ends are always tied up, perhaps because Lewis was in no doubt himself that this homesickness for Joy had some remedy and was anxious to assure his readers of this. Lewis's stories offer a single source of hope, replicating in microcosm Tolkien's idea of the Great Eucatastrophe, the "Christian Joy, the Gloria" (63). Whereas Tolkien's fiction recalls the longing of the Old Testament, Lewis writes in the spirit of the New Testament, in which the Old Testament imagery sees its fulfilment in Jesus: one longs for the Messiah, and the other provides the Messiah, promising the glory to come. These contrasting portrayals of hope and restoration are complementary, two sides of the same coin: both express a yearning for salvation that is partially satisfied, but still to come; a hope of glory that might readily be expressed in the final words of Revelation: “Amen. Even so, come, Lord Jesus” (22:20). 
By re-mythologising a familiar story and a familiar set of beliefs, Tolkien and Lewis convincingly invite fresh engagement with the Christian faith. Tolkien and Lewis believed that, as Os Guinness explains, "all the highest strengths of human creativity [...], eloquence, creativity, imagination, humor and irony" (Fool's Talk 253) might be used to great effect to engage "the hearts and minds of our post-Christian generation" (254). Or as contemporary evangelist Frederick Buechner has put it:

Let the preacher tell the truth. [...] let him preach this overwhelming of tragedy by comedy, of darkness by light, of the ordinary by the extraordinary, as the tale that is too good not to be true because to dismiss it as untrue is to dismiss along with it that catch of the breath, that beat and lifting of the heart near to or even accompanied by tears, which I believe is the deepest intuition of truth that we have. (Telling the Truth 98) 


\section{Bibliography}

Adey, Lionel. C.S. Lewis: Writer, Dreamer, and Mentor. William B. Eerdmans Pub, 1998. Amendt-Raduege, Amy. "The Sweet and the Bitter": Death and Dying in J. R. R. Tolkien's The Lord of the Rings. Kent State University Press, 2018. Library of Congress ISBN, https://ebookcentral-proquestcom.helicon.vuw.ac.nz/lib/vuw/detail.action?docID=5244609.

"Anachronisms in 'The Hobbit' and 'The Lord of the Rings.'” HobbyLark. Hobbylark.com, https://hobbylark.com/fandoms/Anachronisms-in-The-Hobbit-and-Lord-of-theRings. Accessed 18 June 2020.

Anderson, Paul N. The Riddles of the Fourth Gospel: An Introduction to John. Fortress Press, 2011.

“Archetype, n." OED Online, Oxford University Press. Oxford English Dictionary, https://www.oed.com/view/Entry/10344. Accessed 7 Oct. 2020.

Baert, Barbara. A Heritage of Holy Wood: The Legend of the True Cross in Text and Image. Translated by Lee Preedy, Brill, 2004.

Benjamin, Walter. Illuminations. Edited by Hannah Arendt. Translated by Harry Zohn. London: Fontana, 1973.

Berlina, Alexandra. “Introduction to 'Art, as Device."” Poetics Today 36, no. 3 (September 2015): 151-56. https://doi.org/10.1215/03335372-3160709.

Bettelheim, Bruno. The Uses of Enchantment: The Meaning and Importance of Fairy Tales. London: Thames and Hudson, 1976.

Brackmann, Rebecca. “'Dwarves Are Not Heroes': Antisemitism and the Dwarves in J. R. R. Tolkien's Writing." Mythlore, vol. 28, no. 3, Spring/Summer 2010, https://dc.swosu.edu/cgi/viewcontent.cgi?article=1172\&context=mythlore. Boyd, Brian. On the Origin of Stories: Evolution, Cognition, and Fiction. 1. Paperback ed, Belknap Press of Harvard University Press, 2010. 
Bowman, Mary R. “The Story Was Already Written: Narrative Theory in The Lord of the Rings." Narrative, vol. 14, no. 3, Oct. 2006, pp. 272-93.

Bratman, David. "The Inklings and Others: Tolkien and His Contemporaries." A Companion to J. R. R. Tolkien, edited by Stuart D. Lee, Wiley Blackwell, 2014. Library of Congress ISBN, https://ebookcentral-proquestcom.helicon.vuw.ac.nz/lib/vuw/detail.action?docID=1658807.

Brazier, Paul H. “C. S. Lewis and Christological Prefigurement.” The Heythrop Journal, vol. 48, no. 5, Sept. 2007, pp. 742-75.

Bremer, John. “A Brief Biography.” The C.S. Lewis Readers' Encyclopedia, edited by Jeffrey D. Schultz and John G. West, Zondervan, 1998.

Buechner, Frederick. Telling the Truth: The Gospel as Tragedy, Comedy, and Fairy Tale. $1^{\text {st }}$ ed, Harper \& Row, 1977.

Callaway, David. “Gollum: A Misunderstood Hero.” Mythlore, vol. 10, no. 3, Winter 1984, pp. 14-22.

Campbell, Joseph. Primitive Mythology: The Masks of God. 1959. Penguin Books, 1976.

Carpenter, Humphrey. J.R.R. Tolkien: A Biography. George Allen \& Unwin, 1977.

---. The Inklings: C. S. Lewis, J. R. R. Tolkien, Charles Williams, and Their Friends. Allen and Unwin, 1978.

Catholic Church. Catechism of the Council of Trent. Translated by John A McHugh and Charles J Callan, Roman Catholic Books, 2002. Open WorldCat, https://babel.hathitrust.org/cgi/pt?id=mdp.39015038914233\&view=2up\&seq=1 01\&q1=priest, $\% 20$ prophet, $\% 20$ and $\% 20$ king.

Chant, Joy. “Niggle and Númenor." Children's Literature in Education, vol. 6, no. 4, Dec. 1975, pp. 161-71. Crossref, doi:10.1007/BF01146318.

Chesterton, G. K. Orthodoxy. 1908. Ignatius, 1995.

---. “The Romance of Rhyme." 1920. On Lying in Bed and Other Essays by G.K. Chesterton, edited by Alberto Manguel, Bayeux Arts, 2000. 
The Chronicles of Narnia. Directed by Alex Kirby. BBC, 1988-1990. TV films.

The Chronicles of Narnia: Prince Caspian. Directed by Andrew Adamson. Buena Vista Pictures, 2008. Film.

The Chronicles of Narnia: The Lion, the Witch and the Wardrobe. Directed by Andrew Adamson. Walt Disney Studios Motion Pictures, 2005. Film.

The Chronicles of Narnia: The Voyage of the Dawn Treader. Directed by Michael Apted.

Twentieth Century Fox, 2010. Film.

Church of England. "Apostle's Creed." Book of Common Prayer: The Revised Liturgy of 1689, Samuel Bagster and Sons, 1855, p. 3.

---. “Creed: The Communion." Book of Common Prayer: The Revised Liturgy of 1689, Samuel Bagster and Sons, 1855, p. 53.

---. "The Order of Morning Prayer: A General Confession." Book of Common Prayer: The Revised Liturgy of 1689, Samuel Bagster and Sons, 1855, p. 1.

Clute, John, and John Grant, editors. “'Children's Fantasy.”' The Encyclopedia of Fantasy, Orbit, 1997, pp. 184-89.

Cohen, Arthur A. "Myths and Riddles: Some Observations about Literature and Theology." Prooftexts, vol. 7, no. 2, May 1987, pp. 110-21.

Coleridge, Samuel Taylor. Biographia Literaria. 1817 Edited by James Engell and Walter Jackson Bate, Princeton University Press, 1984.

Cook, Eleanor. Enigmas and Riddles in Literature. Cambridge University Press, 2006.

Curry, Patrick. “The Critical Response to Tolkien's Fiction.” A Companion to J. R. R. Tolkien, edited by Stuart D. Lee, Wiley Blackwell, 2014, pp. 369-388.

Davie, Grace. Religion in Britain since 1945: Believing Without Belonging. Blackwell, 1994. Dickerson, Matthew T., and Jonathan D. Evans. Ents, Elves, and Eriador: The Environmental Vision of J.R.R. Tolkien. University Press of Kentucky, 2006. Open WorldCat, http://site.ebrary.com/id/10495395. 
Dickerson, Matthew T., and David O'Hara. Narnia and the Fields of Arbol: The Environmental Vision of C.S. Lewis. University Press of Kentucky, 2009.

Duriez, Colin. J.R.R. Tolkien: The Making of a Legend. First edition, Lion, 2012.

Duriez, Colin, and David Porter. The Inklings Handbook: A Comprehensive Guide to the Lives, Thought, and Writings of C.S. Lewis, J.R.R. Tolkien, Charles Williams, Owen Barfield, and Their Friends. Chalice Press, 2001.

Eco, Umberto. "The Theory of Signs and the Role of the Reader." Bulletin of the Midwest Modern Language Association, vol. 14, no. 1, Spring 1981, pp. 35-45.

Eliot, T. S. “Gerontion." 1920. The Poems of T.S. Eliot: Collected and Uncollected Poems, Volume 1, edited by Christopher Ricks and Jim McCue, 2015, pp. 31-33.

Eusebius. Church History. Early fourth century. Featured in A Select Library of Nicene and Post-Nicene Fathers of the Christian Church: Second Series, Volume 1. Edited by Philip Schaff and Henry Wace, Christian Literature Company, 1890.

Fay, Sarah. “Marilynne Robinson, The Art of Fiction No. 198.” Paris Review, no. 186, Fall 2008. Paris Review, http://www.theparisreview.org/interviews/5863/the-art-offiction-no-198-marilynne-robinson.

Fimi, Dimitra. “Later Fantasy Fiction: Tolkien's Legacy.” A Companion to J. R. R. Tolkien, edited by Stuart D. Lee, Wiley Blackwell, 2014, pp. 335-349. Library of Congress $I S B N$, https://ebookcentral-proquestcom.helicon.vuw.ac.nz/lib/vuw/detail.action?docID=1658807.

Fimi, Dimitra, and Thomas Honegger, editors. Sub-Creating Arda: World-Building in J.R.R. Tolkien's Work, Its Precursors and Its Legacies. Walking Tree Publishers, 2019. Flieger, Verlyn. “But What Did He Really Mean?” Tolkien Studies, vol. 11, 2014, pp. 149-66. ---. "Frodo and Aragorn: The Concept of the Hero." Understanding The Lord of the Rings: The Best of Tolkien Criticism, edited by Rose A Zimbardo and Neil D. Isaacs, Houghton Mifflin, 2005, pp. 122-45.

---. Splintered Light: Logos and Language in Tolkien's World. Eerdmans, 1983. 
Frye, Northrop. Spiritus Mundi: Essays on Literature, Myth, and Society. Indiana University Press, 1976.

---. The Great Code: The Bible and Literature. 1 ${ }^{\text {st }}$ ed, Harcourt Brace Jovanovich, 1982.

Gaiman, Neil. Fragile Things. Hachette UK, 2010.

Garth, John. Tolkien and the Great War: The Threshold of Middle-Earth. Houghton Mifflin, 2005.

Gilchrist, K. J. A Morning After War: C. S. Lewis and WWI. Peter Lang, 2005.

Glyer, Diana Pavlac. The Company They Keep: C. S. Lewis and J. R. R. Tolkien as Writers in Community. 1 paper ed, Kent State Univ. Press, 2008.

Gottschall, Jonathan. The Storytelling Animal: How Stories Make Us Human. Houghton Mifflin Harcourt, 2012.

Gray, William. Death and Fantasy: Essays on Philip Pullman, C.S. Lewis, George MacDonald and R.L. Stevenson. Cambridge Scholars Pub., 2008.

Green, Roger Lancelyn, and Walter Hooper. C. S. Lewis: A Biography. Collins, 1974.

Guinness, Os. Fool's Talk: Recovering the Art of Christian Persuasion. IVP Books, 2015.

Haase, Donald. "Children, War and the Imaginative Space of Fairy Tales." The Lion and the Unicorn, vol. 24, no. 3, Sept. 2000, pp. 360-77.

Haldane, J. B. S. “More Anti-Lewisite.” Everything Has a History, Taylor and Francis, 2016. Hammond, Wayne G. "The Critical Response to Tolkien's Fiction.” Mythlore, vol. 21, no. 2, Oct. 1996, pp. 226-32.

Hammond, Wayne G., and Christina Scull. The Lord of the Rings: A Reader's Companion. HarperCollins, 2008.

Harris, Paul L. The Work of the Imagination. Blackwell Publishers, 2000.

Hart, Trevor A., and Ivan Khovacs, editors. Tree of Tales: Tolkien, Literature, and Theology. Baylor University Press, 2007.

Jahosky, Michael T. The Good News of the Return of the King: The Gospel in Middle-Earth. 2020. 
Hendrickson, Aldean. True Myth: Tolkien's Catholic Imagination. P. 13. www.academia.edu, https://www.academia.edu/1680465/True_Myth_Tolkiens_Catholic_Imagination. Accessed 25 Jan. 2021.

Herbert, George. "Aaron." The English Poems of George Herbert, Cambridge University Press, 2007, p. 601.

---. “The Sonne." The English Poems of George Herbert, Cambridge University Press, 2007, p. 573.

Honegger, Thomas. "Splintered Heroes - Heroic Variety and Its Function in 'The Lord of the Rings."' A Wilderness of Dragons: Essays in Honor of Verlyn Flieger, edited by John D. Rateliff, The Gabbro Head Press, 2018, pp. 157-75.

---. “We Don't Need Another Hero' - Problematic Heroes and Their Function in Some of Tolkien's Works." Journal of Tolkien Research, vol. 9, no. 2, article 8, 2020, pp. 116.

Hooper, Walter. C. S. Lewis: A Complete Guide to His Life and Works. HarperSanFrancisco, 2005.

Jackson, Rosemary. Fantasy, the Literature of Subversion. Methuen, 1981.

James, Jamie. The Music of the Spheres: Music, Science, and the Natural Order of the Universe. Copernicus, 1995.

Jeffrey, David L., editor. A Dictionary of Biblical Tradition in English Literature. W.B. Eerdmans, 1992.

Jeffrey, David Lyle. “Tolkien as Philologist.” Tolkien and the Invention of Myth: A Reader, edited by Jane Chance, University Press of Kentucky, 2004, pp. 61-78.

Jenkins, Sue. “Love, Loss, and Seeking: Maternal Deprivation and the Quest." Children's Literature in Education, vol. 15, no. 2, June 1984, pp. 73-83. Crossref, doi:10.1007/BF01151772.

Julian of Norwich. Revelation of Love. 1373. Edited by John Skinner, $1^{\text {st }}$ ed, Doubleday, 1996. 
Keller, Timothy. The Lord of the Rings and Redemptive Art. Gospel in Life, 13 Dec. 2010, https://gospelinlife.com/downloads/the-lord-of-the-rings-and-redemptive-art/.

Kelly, A. K., and Michael Livingston. “'A Far Green Country': Tolkien, Paradise, and the End of All Things in Medieval Literature." Mythlore, vol. 27, no. 3/4, Spring/Summer 2009, pp. 83-102.

Kennedy, David. The Well of Being: Childhood, Subjectivity, and Education. State University of New York Press, 2006.

King James Bible. 1611. Public Domain, 1987.

Koopman, Eva Maria Emy, and Frank Hakemulder. "Effects of Literature on Empathy and Self-Reflection: A Theoretical-Empirical Framework." Journal of Literary Theory, vol. 9, no. 1, 2015, pp. 79-111.

Kreeft, Peter. The Philosophy of Tolkien: The Worldview Behind The Lord of the Rings. Ignatius Press, 2005.

LaCocque, André. “Cracks in the Wall." Thinking Biblically: Exegetical and Hermeneutical Studies, edited by Paul Ricoeur and David Pellauer, University of Chicago Press, 1998.

Lankford, Ronald D. Sleigh Rides, Jingle Bells, \& Silent Nights: A Cultural History of American Christmas Songs. University Press of Florida, 2013.

Leavitt, Jonathan D., and Nicholas J. S. Christenfeld. "Story Spoilers Don't Spoil Stories.” Psychological Science, vol. 22, no. 9, Sept. 2011, pp. 1152-54. DOI.org (Crossref), doi:10.1177/0956797611417007.

Lebovic, Matt. “Are Tolkien's Dwarves an Allegory for the Jews?” The Times of Israel, 11 Dec. 2013, https://www.timesofisrael.com/are-tolkiens-dwarves-an-allegory-forthe-jews/.

Lee, Stuart D., editor. A Companion to J. R. R. Tolkien. Wiley Blackwell, 2014. Library of Congress ISBN, https://ebookcentral-proquestcom.helicon.vuw.ac.nz/lib/vuw/detail.action?docID=1658807. 
Levinas, Emmanuel. Entre Nous: On Thinking-of-the-Other. The Athlone Press, 1998.

Lewis, C. S. A Preface to Paradise Lost. 1942. Oxford University Press, 1942.

---. "A Reply to Professor Haldane." 1956. Of This and Other Worlds, edited by Walter Hooper, Collins, 1982, pp. 97-109.

---. An Experiment in Criticism. Cambridge University Press, 1961.

---. "Bluspels and Flalansferes." Rehabilitations and Other Essays, Oxford University Press, 1939, pp. 133-58,

https://archive.org/details/in.ernet.dli.2015.86873/page/n7/mode/2up. Internet Archive Library.

---. Broadcast Talks. Geoffrey Bles, 1942.

---. "It All Began With a Picture..." Of This and Other Worlds, Collins, 1982.

---. Letters to Children. Collins, 1985.

---. Mere Christianity. 1952. HarperCollins Publishers, 2002.

---. "Myth Became Fact." 1970. God in the Dock: Essays on Theology and Ethics, edited by Walter Hooper, 2014.

---. “On Stories.” Of This and Other Worlds, Collins, 1982, pp. 25-45.

---. "On Three Ways of Writing for Children." Of This and Other Worlds, edited by Walter Hooper, Collins, 1982, pp. 56-70.

---. Out of the Silent Planet. 1938. HarperCollins Publishers, 2013.

---. Perelandra. 1943. HarperCollins Publishers, 2013.

---. Prince Caspian. 1951. 24th impr, Lions, 1989.

---. Screwtape Letters. 1942. Fount, 1998.

---. “Sometimes Fairy Stories May Say Best What's to Be Said." Of This and Other Worlds, Collins, 1982, pp. 71-75.

---. Surprised by Joy. 1955. Fontana Books, 1959.

---. The Allegory of Love: A Study in Medieval Tradition. 1936. Oxford University Press, 1958. 
---. The Collected Letters of C.S. Lewis: Volume I. HarperSanFrancisco, 2004.

---. The Collected Letters of C.S. Lewis: Volume II. HarperSanFrancisco, 2004.

---. The Collected Letters of C.S. Lewis: Volume III. HarperSanFrancisco, 2004.

---. The Discarded Image: An Introduction to Medieval and Renaissance Literature. 1964.

Cambridge University Press, 1970.

---. The Great Divorce. 1945. HarperCollins, 2002.

---. “The Hobbit." 1937. Of This and Other Worlds, edited by Walter Hooper, Collins, 1982.

---. The Horse and His Boy. 1954. 22nd impr, Lions, 1989.

---. The Last Battle. 1956. 22nd impr, Lions, 1989.

---. The Lion, the Witch and the Wardrobe. 1950. 14th impr, Lions, 1989.

---. The Magician's Nephew. 1955. 14th impr, Lions, 1994.

---. The Problem of Pain. 1940. Collins, 2012.

---. The Screwtape Letters. 1942. Fount, 1998.

---. The Silver Chair. 1953. 25 th impr, Lions, 1989.

---. The Voyage of the Dawn Treader. 1952. 23 $3^{\text {rd }}$ impr, Lions, 1989.

---. Till We Have Faces. 1956. Collins, 1979.

---. “Transposition.” In Screwtape Proposes a Toast: And Other Pieces. London: Fount, 1998.

Lively, Penelope. "The Wrath of God: An Opinion of the 'Narnia' Books.” The Use of English, vol. 20, no. 2, 1968, pp. 126-29.

Loconte, Joseph. Hobbit, a Wardrobe, and a Great War. Thomas Nelson Pub, 2017.

The Lord of the Rings: The Return of the King. Directed by Peter Jackson. New Line Cinema, 2003. Film.

The Lord of the Rings: The Two Towers. Directed by Peter Jackson. New Line Cinema, 2002. Film.

Manlove, C. N. C.S. Lewis: His Literary Achievement. Winged Lion Press, 2010.

Markos, Louis. From Achilles to Christ: Why Christians Should Read the Pagan Classics. InterVarsity Press, 2007. 
Matheson, Sue. "C. S. Lewis and the Lion: Primitivism and Archetype in the Chronicles of Narnia." Mythlore, vol. 15, no. 1, Fall 1988, pp. 13-18.

McGrath, Alister E. C. S. Lewis, a Life: Eccentric Genius, Reluctant Prophet. Hodder \& Stoughton, 2013.

McLeod, Hugh, editor. The Cambridge History of Christianity. $1^{\text {st }}$ ed., Cambridge University Press, 2006. DOI.org (Crossref), doi:10.1017/CHOL9780521815000.

Mendlesohn, Farah. Rhetorics of Fantasy. Wesleyan University Press, 2008.

Milbank, Alison. "Apologetics and the Imagination: Making Strange." Imaginative Apologetics: Theology, Philosophy and the Catholic Tradition, edited by Andrew Davison, SCM Press, 2011, pp. 31-58.

---. Chesterton and Tolkien as Theologians: The Fantasy of the Real. T\&T Clark, 2009.

---. "Literary Apologetics beyond Postmodernism: Duality and Death in Philip Pullman and J. K. Rowling." Theology and Literature after Postmodernity, edited by Zoë Lehmann Imfeld et al., T\&T Clark, 2015, pp. 95-113.

Miller, Laura. The Magician's Book: A Skeptic's Adventures in Narnia. $1^{\text {st }}$ ed, Little, Brown and Co, 2008.

Mitchell, Christopher W. "Foreword.” The C.S. Lewis Readers' Encyclopedia, Zondervan, 1998.

Mitchell, Stanley. “From Shklovsky to Brecht: Some Preliminary Remarks Towards a History of the Politicisation of Russian Formalism." Screen, vol. 15, no. 2, 1974, pp. $74-81$.

Moran, Lee. 'Reading Is Just Looking At A Dead Piece Of Wood For Hours And Hallucinating': The 25 Most Profound "Shower Thoughts" on Reddit From the Last Week. https://www.huffpost.com/entry/reddit-shower-thoughts-january-2018-part3_n_5a61cdf3e4b074ce7a0743f2. Accessed 20 Apr. 2020. 
Murray, Robert. "J.R.R. Tolkien and the Art of the Parable.” Tolkien, A Celebration: Collected Writings on a Literary Legacy, edited by Joseph Pearce, U.S. ed, Ignatius Press, 2001, pp. 40-52.

Myers, Doris T. C. S. Lewis in Context. The Kent State University Press, 1998.

Nelson, Brent. “Cain-Leviathan Typology in Gollum and Grendel.” Extrapolation, vol. 49, no. 3, 2008, pp. 466-85.

Nelson, Michael. “C. S. Lewis and His Critics.” The Virginia Quarterly Review, vol. 64, no. 1, Winter 1988, pp. 1-19.

Newman, John Henry. "Sermon 5. The Three Offices of Christ." Newman Reader - Works of John Henry Newman,

http://www.newmanreader.org/works/subjects/sermon5.html. Accessed 4 Oct. 2020.

Plimmer, Charlotte, et al. “The Man Who Understands Hobbits." London Daily Telegraph Magazine, 22 Mar. 1968, pp. 31-32, 35.

Pratchett, Terry, and Therese Littleton. Post-Fantasy Fantasy: An Interview with Terry Pratchett. 2000,

https://www.amazon.com/gp/feature.html?ie=UTF8\&docId=35534.

Purtill, Richard L. J.R.R. Tolkien: Myth, Morality, and Religion. Ignatius Press, 2003.

Ricoeur, Paul. Oneself as Another. 1990. University of Chicago Press, 1992.

---. “The Image of God' and the Epic of Man." CrossCurrents, translated by George Gingras, vol. 11, no. 1, WINTER 1961, pp. 37-50.

“Riddle, v.2." OED Online, Oxford University Press. Oxford English Dictionary, https://www.oed.com/view/Entry/165636. Accessed 21 Oct. 2020.

Robinson, Marilynne. “Theology.” The Givenness of Things: Essays, 2016.

Rush, Ormond. "The Offices of Christ, Lumen Gentium and the People's Sense of the Faith." Pacifica: Australasian Theological Studies, vol. 16, no. 2, June 2003, pp. 137-52. DOI.org (Crossref), doi:10.1177/1030570X0301600202. 
Ruud, Jay. "The Voice of Saruman: Wizards and Rhetoric in The Two Towers." Mythlore, vol. 28, no. 3/4, Spring-Summer 2010, pp. 141-53.

Ryken, Philip Graham. The Messiah Comes to Middle-Earth: Images of Christ's Threefold Office in The Lord of the Rings. EBook, InterVarsity Press, 2017.

Sacks, Oliver. The Man Who Mistook His Wife for a Hat and Other Clinical Tales. $1^{\text {st }}$ Touchstone ed, Simon \& Schuster, 1998.

Salu, Mary, and Robert T. Farrell, editors. J. R. R. Tolkien, Scholar and Storyteller: Essays in Memoriam. Cornell University Press, 1979.

Sammons, Martha C. War of the Fantasy Worlds: C.S. Lewis and J.R.R. Tolkien on Art and Imagination. Praeger, 2010.

Sample, Micah. Lewisian "True Myth" and the Jungian Theory of Archetypes. Indiana Wesleyan University, 2019, https://www.academia.edu/38972919/Lewisian True Myth and the Jungian Th eory of Archetypes.

Sbroma, Angelina. “Intimations of Mortality: Death in Twentieth-Century Children's Fantasy." Victoria University of Wellington, 2018. Digital access.

Schakel, Peter J. "Till We Have Faces.” The Cambridge Companion to C.S. Lewis, edited by Robert MacSwain and Michael Ward, Cambridge University Press, 2010, pp. 28193.

Schmid, Wolf. “Defamiliarisation." In Routledge Encyclopedia of Narrative Theory, edited by David Herman, Manfred Jahn, and Marie-Laure Ryan, (online). London; New York: Routledge, 2005. (online).

Scull, Christina, and Wayne G. Hammond. The J.R.R. Tolkien Companion \& Guide: Reader's Guide. Houghton Mifflin Co, 2006.

Shippey, T. A. J.R.R. Tolkien: Author of the Century. Ebook, Houghton Mifflin, 2001.

---. The Road to Middle-Earth. Allen \& Unwin, 1982. 
Shklovsky, Viktor. "Art as Technique." 1917. Theory of Prose, translated by Benjamin Sher, Kalkey Archive Press, 1991, pp. 1-14.

Spufford, Francis. The Child That Books Built: A Life in Reading. Picador, 2002.

Stimson, Amy. "Singing into Being: Defamiliarisation as Creation in J. R. R. Tolkien and C. S. Lewis", Fantasy Art and Studies - Les Têtes Imaginaires, edited by Viviane Bergue, Issue 10, June 2021.

Tatar, Maria, editor. The Cambridge Companion to Fairy Tales. Cambridge University Press, 2015.

The Lord of the Rings: The Return of the King. Directed by Peter Jackson. New Line Cinema, 2003. Film.

The Lord of the Rings: The Two Towers. Directed by Peter Jackson. New Line Cinema, 2002. Film.

Tolkien, J. R. R. Letters ofJ. R. R. Tolkien: A Selection. Allen \& Unwin, 1981.

---. "Mythopoeia." Tree and Leaf, Houghton Mifflin,1998, pp. 97-101.

---. “On Fairy-Stories.” 1947. Tree and Leaf, Allen \& Unwin, 1964.

---. The Fellowship of the Ring. 1954. HarperCollins, 2012.

---. The Hobbit. 1937. Revised Edition, Ballantine Books, 1973.

---. The Return of the King. 1955. HarperCollins, 2012.

---. The Silmarillion. 1977. HarperCollins, 2008.

---. The Two Towers. 1954. HarperCollins, 2012.

Toynbee, Polly. “'Narnia Represents Everything That Is Most Hateful about Religion.”' The Guardian, 5 Dec. 2005. www.theguardian.com, https://www.theguardian.com/books/2005/dec/05/cslewis.booksforchildrenan dteenagers.

Vanauken, Sheldon. A Severe Mercy: C.S. Lewis and a Pagan Love Invaded by Christ, Told by One of the Lovers. 1977. Hodder \& Stoughton, 1979. 
Walker, Maxine E. “'How Do You Read It?' Rowan Williams, Marilynne Robinson and Mapping a Postmodern Reading of the Good Samaritan Parable." Journal of Anglican Studies, vol. 12, no. 2, Nov. 2014, pp. 203-25, doi:10.1017/S1740355313000326.

Wall, Barbara. Narrator's Voice. Palgrave Macmillan, a division of Macmillan Publishers Limited, 1991. Open WorldCat, https://link.springer.com/book/10.1007/978-1$349-21111-1$.

Walls, Kathryn. “An Analogous Adversary: The Old Dispensation in The Lion, the Witch and the Wardrobe." Journal of the Fantastic in the Arts, vol. 28, no. 2, 2017, pp. 202-18. ---. "When Curiosity Gets the Better of Us: The Atomic Bomb in The Magician's Nephew." Journal of the Fantastic in the Arts, vol. 20, no. 3, 2009, pp. 334-49.

Walsh, Chad. The Literary Legacy of C.S. Lewis. Wipf \& Stock, 2008.

Ward, Michael. Planet Narnia: The Seven Heavens in the Imagination of C.S. Lewis. Oxford University Press, 2008. Library of Congress ISBN, https://oxford.universitypressscholarship.com/view/10.1093/acprof:oso/97801 95313871.001.0001/acprof-9780195313871.

Williams, Rowan. On Christian Theology. Blackwell Publishers, 2000.

Wilson, A. N. C.S. Lewis: A Biography. EBook. Harper Perennial, 2005. Open WorldCat, https://www.overdrive.com/search?q=29D1E317-4F14-4052-96E39885278B4C61.

Wolf, Mark J. P. Building Imaginary Worlds: The Theory and History of Subcreation. Routledge, 2013.

Wood, Naomi. "Paradise Lost and Found: Obedience, Disobedience and Storytelling in C. S. Lewis and Phillip Pullman." Children's Literature in Education, vol. 32, no. 4, Dec. 2001, pp. 237-59.

Wood, Ralph C. Literature and Theology. Horizons in Theology. Nashville: Abingdon Press, 2008. 
Zaleski, Philip, and Carol Zaleski. The Fellowship: The Literary Lives of the Inklings. 2016.

Zipes, Jack. Fairy Tales and the Art of Subversion: The Classical Genre for Children and the Process of Civilization. 2nd ed, Routledge, 2006. 


\section{Acknowledgements}

First and foremost, I owe the greatest debt of gratitude to my supervisors, Kathryn Walls and Peter Whiteford. You put enormous intellectual work into this research, supporting these ideas from day one of the application process. I am so thankful for your input, dedication, enthusiasm, rigour, and belief in the potential of my thesis (and me).

I am very grateful for the Victoria Doctoral Scholarship, without which this study would not have been possible. Many thanks are due to Alison Milbank, who was the first person interested in this project and encouraged my research in various ways, especially in the early days. I am also indebted to Catherine McIlwaine for her assistance at the Bodleian and Weston Libraries, and the editors at Fantasy Art and Studies for accepting an article for publication.

To the English department at Victoria University, especially Angelina Sbroma, Talia Crockett, and Patrick Biggs, this research owes so much to your stimulating conversations, encouragement, friendship, musings, books, movies, and memes.

To the New Zealand friends and whānau who have supported me through this, I can't express how much I have been blessed by you - I'm looking at you, Therons, Quizzards, iDance Wellington, postgrad friends (Tessa, Ina, Yuanyuan, Sara, and Bobby), Lecy, Sal, Grace, Melandi, Christine, Jo, Thapi, Norrises, the City on a Hill church, and the VUW Chaplaincy. Thank you for keeping me sane, for the breaks, books, conversations, coffees, laughter, tissues, and for generally cheering me on.

To the friends and whānau at home in South Africa and abroad, I could not have done this without you coming alongside me in various ways: Amy, Steph, Ruthie, the writing buddies who inspired and supported me creatively, Caro, Irene, Tracy, the prayer-warriors, essentially the ones who couldn't carry it for me, but did carry me. And Margie, and Dylan. And huge thanks to my cousin James Cuenod, who was an excellent sounding board, asked questions, and made observations that piqued my interest and prompted research into some of my favourite topics in this dissertation. ${ }^{188}$

To my sister for always reminding me why on earth I did this, fighting to keep my spirits up, what a cheerleader you have been! Katie, Cudi, Hannah, and Jo, love you forever. Thanks for letting me read Gollum passages to your toddlers (with all the voices).

To my wonderful parents, for championing me on the twisty road through postgraduate studies, thanks and love beyond words for everything from reading aloud to me when I was

${ }^{188}$ And for being a gracious loser in our race to be the first to get a PhD. It was me. Hah. 
little (instilling a lifelong love), to thinking through obstacles, and offering support of every possible and imaginable kind. Love you four times round the world plus <-------> much.

Finally, to the One to whom all thanks are due. To borrow someone else's prayer, may all I am and all I write be worthy of the Word who was in the beginning with God, the Word who will have the last word as he had the first, the Word who was made flesh and lived among us, and the Word whose name is Love.

If it all reveals your nature,

So will I. 